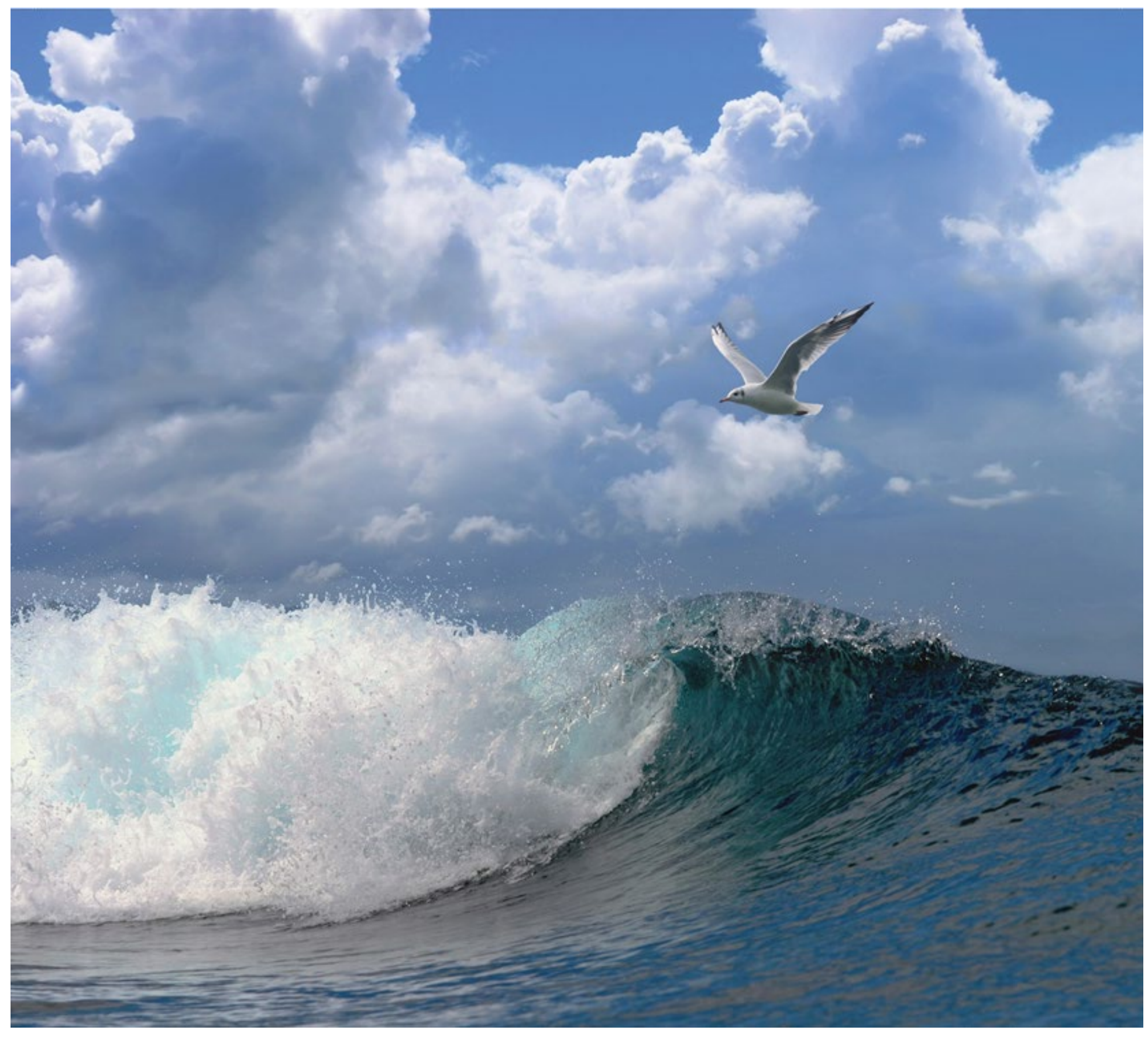

\title{
Reacties zeevogels in windparken bij doorvaart
}

Auteurs: Mardik Leopold, Steve Geelhoed, Hans Verdaat, Susanne Kühn \& Marinka van Puijenbroek
Wageningen University \&

Research rapport C066/18a 


\section{Reacties zeevogels in windparken bij doorvaart}

Auteurs: $\quad$ Mardik Leopold, Steve Geelhoed, Hans Verdaat, Susanne Kühn \& Marinka van Puijenbroek

Publicatiedatum: 30 november 2018 
Mardik Leopold, Steve Geelhoed, Hans Verdaat, Susanne Kühn \& Marinka van Puijenbroek, 2018. Reacties zeevogels in windparken bij doorvaart. Wageningen Marine Research Wageningen UR (University \& Research centre), Wageningen Marine Research rapport. 32 blz. excl. bijlagen.

Opdrachtgever: Rijkswaterstaat Zee en Delta Directie Netwerkontwikkeling T.a.v. Vincent van der Meij Lange Kleiweg 34

2280 GK Rijswijk

Dit rapport is gratis te downloaden van https://doi.org/10.18174/459958

Wageningen Marine Research verstrekt geen gedrukte exemplaren van rapporten.

Wageningen Marine Research Wageningen UR is ISO 9001:2008 gecertificeerd.

(C) 2018 Wageningen Marine Research Wageningen UR

Wageningen Marine Research, onderdeel van De Directie van Wageningen Marine Research is niet aansprakelijk voor Stichting Wageningen Research gevolgschade, noch voor schade welke voortvloeit uit toepassingen van de resultaten KvK nr. 09098104, IMARES BTW nr. NL 8113.83.696.B16. Code BIC/SWIFT address: RABONL2U van werkzaamheden of andere gegevens verkregen van Wageningen Marine Research opdrachtgever vrijwaart Wageningen Marine Research van aanspraken van derden in verband met deze toepassing.

IBAN code: NL 73 RABO 0373599285 Dit rapport is vervaardigd op verzoek van de opdrachtgever hierboven aangegeven en is zijn eigendom. Niets uit dit rapport mag weergegeven en/of gepubliceerd worden, gefotokopieerd of op enige andere manier gebruikt worden zonder schriftelijke toestemming van de opdrachtgever. 


\section{Inhoudsopgave}

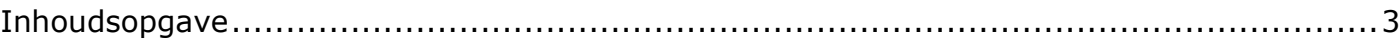

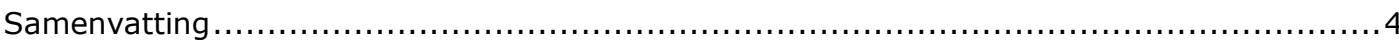

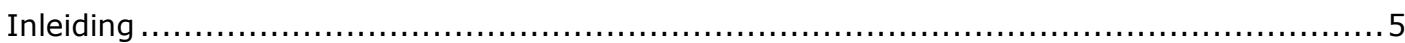

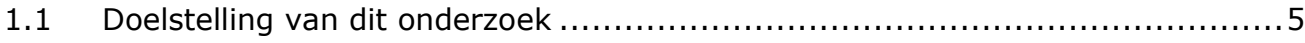

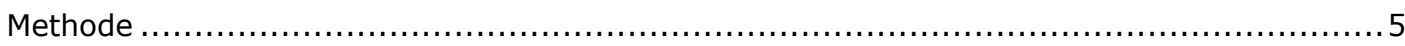

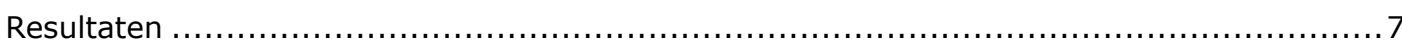

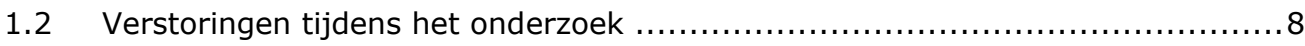

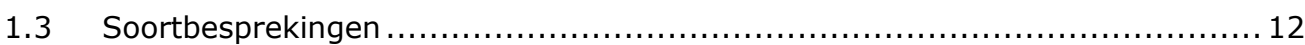

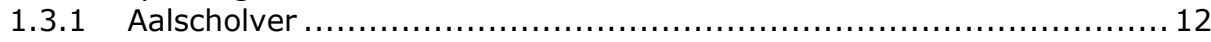

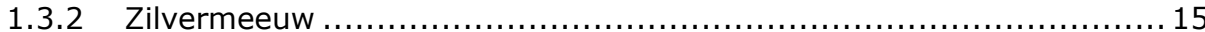

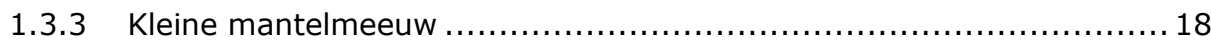

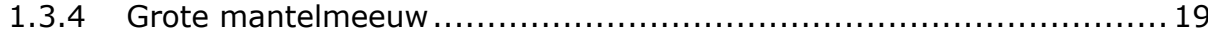

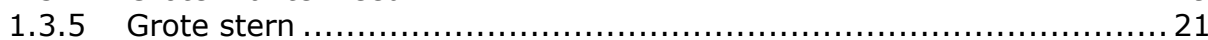

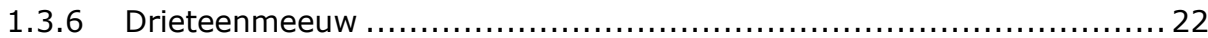

1.3.7 Andere kleinere meeuwen: kokmeeuw en stormmeeuw ................. 22

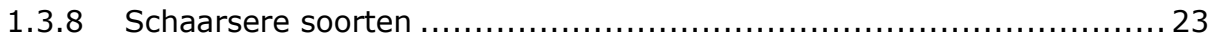

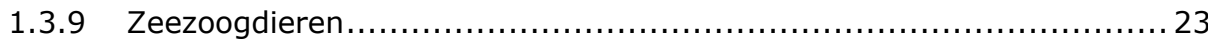

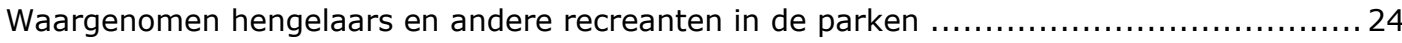

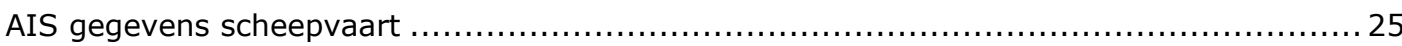

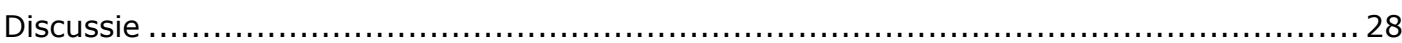

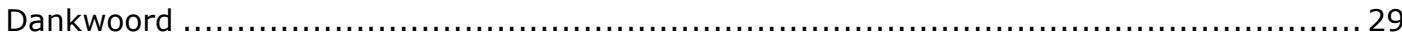

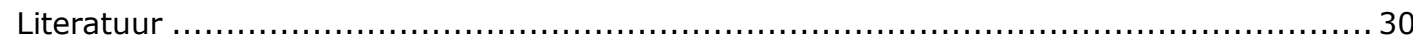

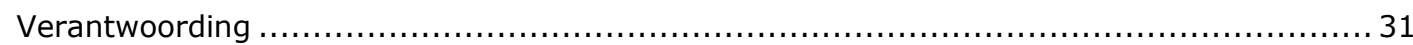




\section{Samenvatting}

Op 1 mei 2018 zijn de drie operationele windparken voor de Hollandse kust (Offshore Windpark Egmond aan Zee - OWEZ, Prinses Amalia Windpark - PWAP en Windpark Eneco Luchterduinen - LUD)

opengesteld voor doorvaart en medegebruik door kleine schepen. De verwachting was, dat onder meer sportvissers van de geboden mogelijkheid gebruik zullen maken, en dat er vanaf bootjes (particulieren en charters) in de windparken zal worden gehengeld. Een hypothese is, dat zeevogels, met name meeuwen, maar mogelijk ook jan-van-genten en aalscholvers, door hengelactiveit in de parken worden aangetrokken waardoor de kans op dodelijke botsingen met de wieken van de turbines toeneemt. RWS heeft WMR gevraagd om, na een voorverkenning in de maanden november-december 2017 en januari 2018 (gerapporteerd door Leopold \& Verdaat 2018), ook in juni-oktober 2018 () vast te stellen hoeveel zeevogels gebruikmaken van het park en waar ze zich vooral bevinden.

In deze rapportage worden de resultaten besproken van vijf surveys, uitgevoerd in de zomer van 2018: een maandelijkse survey in juni tot en met oktober. In deze zomer- en vroege herfstmaanden werd in de drie windparken een vergelijkbaar aantal soorten zeevogels waargenomen als in de winter (11 versus 13), maar soorten die in de zomermaanden elders op rotskusten broeden waren relatief schaars. Aalscholvers en "grote meeuwen" (kleine en grote mantelmeeuw en zilvermeeuw) waren net als in de voorgaande winter het talrijkst aanwezig in de windparken, en ook het sterkst geassocieerd met de turbines: deze soorten werden niet alleen vliegend en zwemmend in de parken gezien, maar ook rustend op de fundaties. De enige andere vogelsoorten die in redelijke aantallen werd waargenomen waren de grote stern (in juni) en de drieteenmeeuw (in oktober; Tabel 2).

Het aantal visueel waargenomen bootjes met hengelaars bleef beperkt tot twee in juni, in windpark Luchterduinen en een in augustus in OWEZ. In het park aanwezige zeevogels vertoonden geen zichtbare reacties op deze bootjes. Op afstand werden alle scheepsbewegingen echter geregistreerd door de kustwacht en geanalyseerd door onderzoeksinstituut MARIN, op basis van AIS-gegevens. Bootjes met hengelaars werden, samen met andere recreatievaart, in één categorie ('Recreation') samengevoegd. Binnen deze categorie werden in de maanden juni tot en met oktober 161 scheepsbewegingen door de drie windparken geregistreerd en aangenomen mag worden dat aanzienlijk meer dan de drie waargenomen bootjes met hengelaars de parken hebben bezocht. Met slechts drie visuele waarnemingsdagen, en zonder dat er reacties van zeevogels op het hengelen aan boord van die bootjes werd waargenomen, is het nog onduidelijk of zeevogels een verhoogd risico op aanvaringen in de windparken lopen, nu deze voor kleine scheepvaart zijn opengesteld. 


\section{Inleiding}

De offshore windparken in Nederland waren tot voor kort gesloten voor alle niet werk-gerelateerde scheepvaart; doorvaart en medegebruik door derden waren niet toegestaan. Met het oog op de toenemende ruimtedruk op de Noordzee, is het beleid aangepast en is met ingang van 1 mei 2018, onder voorwaarden, in drie operationele windparken op zee (Offshore Windpark Egmond aan Zee OWEZ, Prinses Amalia Windpark - PWAP en Windpark Eneco Luchterduinen - LUD) doorvaart en medegebruik toegestaan (www.noordzeeloket.nl/nieuws/nieuws/2018/doorvaart/). In het kort komen de voorwaarden er op neer dat de windparken zijn opengesteld voor kleinere schepen ( $\leq 24 \mathrm{~m}$ ), die geen direct gevaar vormen voor de infrastructuur van het windpark, die vanaf de wal te volgen zijn, die zich niet bezig houden met bodem beroerende activiteiten en die steeds een afstand houden van ten minste 50 meter tot iedere windturbine in het park en 500 meter van een OHVS (Offshore Hoog Voltage (Sub) Station).

De openstelling onder voorwaarden maakt het onder meer mogelijk voor sportvissers om de parken te bezoeken en hier te gaan hengelen. Het is bekend dat zich rond de fundaties van de turbines scholen vis (bijvoorbeeld kabeljauw, steen- en dwergbolk, horsmakreel, makreel en sprot) kunnen ophouden (Soldal et al. 2002; Leonhard \& Pedersen 2006; Winter et al. 2010; Fujii 2016). Mogelijk trekken de activiteiten van hengelaars zeevogels, zoals meeuwen, aan. Zeevogels die door een windpark vliegen, terwijl ze gefocust zijn op wat zich rond een hengelaarsbootje afspeelt, zouden kunnen botsen met de wieken van de turbines.

\subsection{Doelstelling van dit onderzoek}

Rijkswaterstaat (RWS) heeft Wageningen Marine Research (WMR) gevraagd om gedurende het vaarseizoen 2018 (voor deze verkenning afgebakend als de periode juni-oktober 2018) de aanwezigheid en het gedrag van zeevogels (al dan niet gerelateerd aan de aanwezigheid van schepen) te verkennen volgens een met de voorverkenning in winter 2017/2018 (Leopold \& Verdaat 2018), vergelijkbaar vaarplan, gemiddeld één velddag per maand. Het doel van dit onderzoek is om te verkennen of er effecten zijn van doorvaart en medegebruik (door sportvissers en andere bezoekers van de windparken), en daarbij ook of er daarin verschillen zijn binnen de tijdsspanne juni-oktober. De verkenning moet duidelijk maken of er aanleiding is tot onderzoek in een later stadium. Aanvullend is WMR gevraagd om de eigen veldwaarnemingen te relateren aan de vaarbewegingen zoals deze door het MARIN in beeld zijn gebracht, op basis van AIS-gegevens. WMR is gevraagd een gedegen inschatting te geven van al dan niet aanwezige effecten op zeevogels gerelateerd de aanwezigheid van scheepvaart en of hengelvissers in het betreffende windpark

\section{Methode}

Voor de verkenning is gebruik gemaakt van een klein schip (Ixbxd: 12×3.9x1 m; https://www.hetsop. $\mathrm{nl} / \mathrm{nl}$ ) met een cruise snelheid van ruim 20 knopen, waardoor bij vroeg vertrek alle drie de parken in één dag kunnen worden bezocht. Windparkeigenaren en Kustwacht werden vooraf ingelicht. Binnen het park is radiocontact onderhouden met aldaar werkende onderhoudsschepen en werd om veiligheidsredenen steeds ruime afstand gehouden van alle windturbines, OHVS (parken Prinses Amalia en Luchterduinen) en de meetmast bij park OWEZ. 


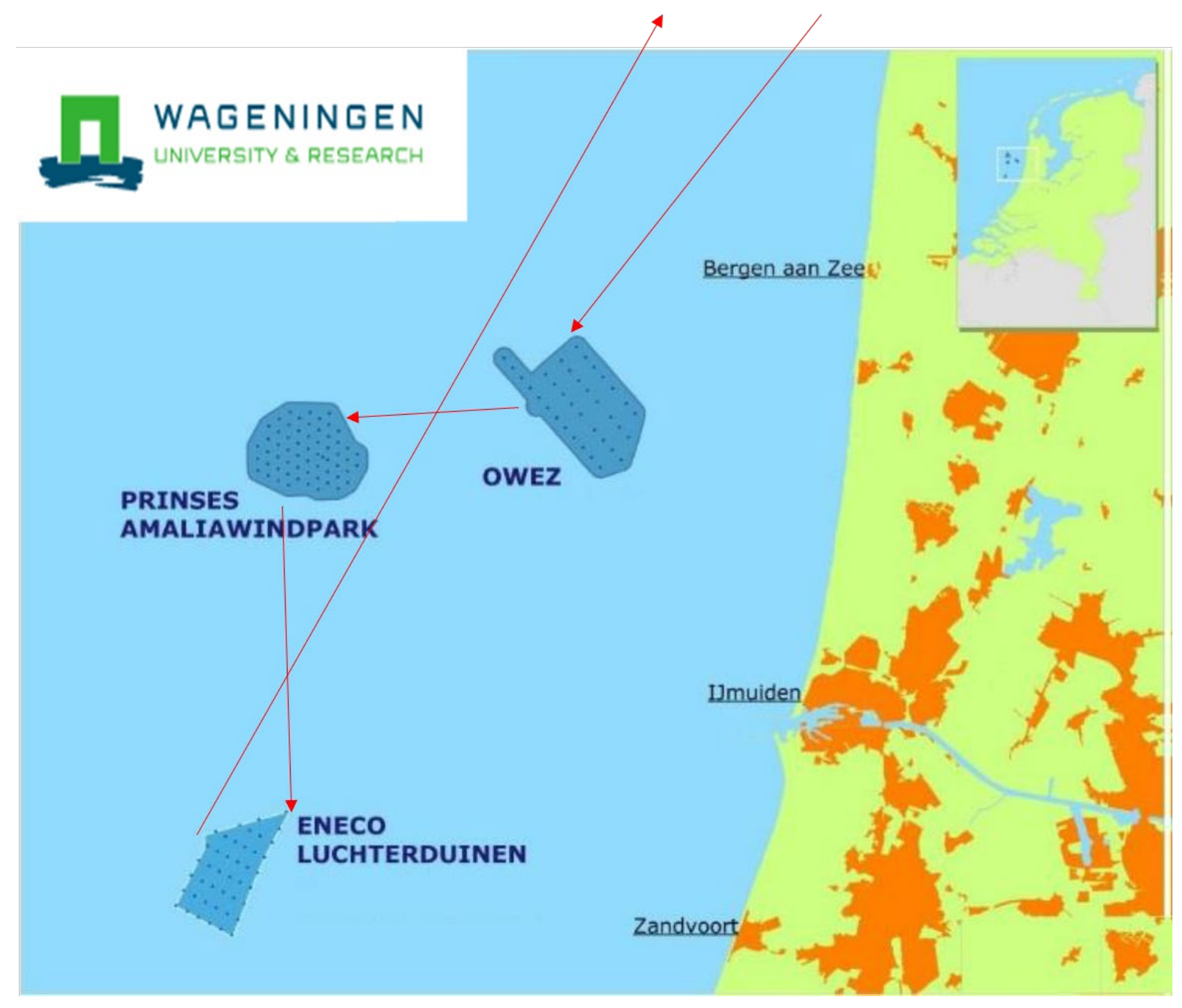

Figuur 1. Gevaren route volgens het vaarplan naar en tussen de parken en retour naar Texel.

Het vaarplan bevat de te varen route naar de parken en retour naar Texel, alsmede de te varen route binnen ieder park (Figuur 1).

Per maand is één survey uitgevoerd, waarbij steeds alle drie de windparken binnen het onderzoeksgebied werden bezocht: Offshore Windpark Egmond aan Zee (OWEZ, eigenaar Vattenfall), Prinses Amalia Wind Park (PAWP, eigenaar Eneco) en Luchterduinen (LUD, eigenaar Eneco). De timing van de afzonderlijke surveys is weergegeven in Tabel 1 . Twee surveys werden rond het midden van de maand uitgevoerd (in juli en in oktober); de overige drie surveys aan het einde van de maand.

Tabel 1. Overzicht van de timing van de vijf surveys die voor dit onderzoek zijn uitgevoerd in 2018.

\begin{tabular}{|l|c|}
\hline Surveymaand & datum \\
\hline Juni & $27 / 06$ \\
\hline Juli & $19 / 07$ \\
\hline Augustus & $29 / 08$ \\
\hline September & $29 / 09$ \\
\hline Oktober & $10 / 10$ \\
\hline
\end{tabular}


Binnen ieder windpark is een zodanige route gevaren, dat alle windmolens goed konden worden bekeken. Alle vogels werden genoteerd die:

1. rustten op de fundaties (etc.: OHVS, meetmast), met het turbinenummer;

2. foerageerden aan de basis van fundaties (etc.), met het turbinenummer;

3. zich op het water bevonden, dan wel in het water doken, met het nummer van de dichtstbijzijnde turbine;

4. door het windpark vlogen, met het nummer van de dichtstbijzijnde turbine; een aantekening werd gemaakt wanneer deze vogels het onderzoekschip opzochten en volgden.

Aan het einde van iedere toer door een windpark werd een locatie midden in het park opgezocht en werd de vaart uit het schip gehaald. Tijdens (exact) 15 minuten werd door drie personen op het achterdek gevist, met boothengels die daarvoor gewoonlijk werden gebruikt, voorzien van kunstaas (verenpaternosters). De vierde persoon aan boord noteerde alle vogels die interesse toonden in deze activiteiten.

In 2018 zijn vijf tochten uitgevoerd, maandelijks van juni tot en met oktober. Deze vijf tochten zijn volgens het zelfde stramien worden uitgevoerd als dat van drie tochten in de winter van 2017/18 (Leopold \& Verdaat 2018). Tijdens deze eerdere drie tochten waren de parken nog niet opengesteld voor doorvaart en vonden plaats in de maanden november, december en januari, dus in een ander seizoen dan de vijf surveys die in dit rapport worden besproken.

\section{Resultaten}

Alle vijf de surveys verliepen succesvol: binnen de daglichtperiode konden de drie parken worden bezocht en konden alle turbines (etc.) worden geïnventariseerd, alsmede het water en het luchtruim tussen de turbines. Er waren geen issues met weersomstandigheden die op enig moment met waarnemen onmogelijk maakten, zoals mist, wind of regen.

In totaal werden er twaalf soorten zeevogels gezien tijdens de vijf surveys in de drie parken (Tabel 2), plus nog een aantal meer of minder aan land gebonden soorten. De aalscholver was in alle parken en tijdens alle surveys in de zomer en herfst van 2018 de meest talkrijke vogelsoort die werd waargenomen. Grote meeuwen (kleine en grote mantelmeeuw en zilvermeeuw) waren ook steeds in de parken aanwezig, zij het niet altijd in ieder park. Grote sterns waren opvallend talrijk in OWEZ in juni, maar schaars in andere maanden en andere parken; drieteenmeeuwen waren opvallend talrijk in de herfst. Het voorkomen van alle andere soorten was meer incidenteel, al was de aanwezigheid van een slechtvalk in LUD in de herfst wellicht meer structureel: een vogel leek het OHVS in dat park als basis te gebruiken, en was er zangvogeltrek (graspiepers en spreeuwen) door de parken in de herfst waarneembaar.

Zeevogelsoorten die tijdens de eerdere zomersurveys wat talrijker aanwezig waren in de windparken voor de Hollandse kust (jan-van-genten, alken en zeekoeten) werden tijdens de zomersurveys niet, en tijdens de herfstsurveys slechts in kleine aantallen gezien in de windparken. Dit zijn allemaal broedvogels van rotskusten die niet in Nederland broeden; de dichtstbijzijnde broedkolonies bevinden zich langs de Britse oostkust en op Helgoland. 
Tabel 2. Aantallen waargenomen zeevogels per survey en per windpark. In iedere cel staan achtereenvolgens de totalen (op fundaties rustende, vliegende en zwemmende vogels samen genomen) voor respectievelijk OWEZ/PAWP/LUD.

\begin{tabular}{|c|c|c|c|c|c|}
\hline Vogelsoort & Juni & Juli & Augustus & September & Oktober \\
\hline Rotgans & & & & & $1 / 0 / 0$ \\
\hline Jan-van-gent & & & $0 / 0 / 1$ & $1 / 0 / 0$ & $1 / 0 / 0$ \\
\hline Aalscholver & $253 / 358 / 409$ & $305 / 163 / 220$ & $238 / 113 / 181$ & $267 / 90 / 45$ & $371 / 113 / 35$ \\
\hline Blauwe reiger & & & & & $0 / 0 / 1$ \\
\hline Slechtvalk & & & & $0 / 0 / 1$ & $0 / 0 / 1$ \\
\hline Kievit & & & $0 / 0 / 1$ & & \\
\hline Kokmeeuw & & $0 / 0 / 1$ & $3 / 3 / 5$ & & $2 / 0 / 3$ \\
\hline Stormmeeuw & & $1 / 0 / 1$ & & & $3 / 0 / 9$ \\
\hline Zilvermeeuw & $0 / 5 / 1$ & $7 / 0 / 0$ & $11 / 2 / 1$ & $12 / 3 / 4$ & $3 / 3 / 10$ \\
\hline Kleine mantelmeeuw & $9 / 0 / 10$ & $10 / 5 / 21$ & $7 / 0 / 11$ & $6 / 2 / 0$ & $5 / 1 / 0$ \\
\hline $\begin{array}{l}\text { Zilver/Kleine } \\
\text { mantelmeeuw }\end{array}$ & $0 / 0 / 10$ & & & & \\
\hline Grote mantelmeeuw & & $9 / 3 / 2$ & $27 / 14 / 34$ & $107 / 50 / 62$ & $36 / 42 / 33$ \\
\hline Drieteenmeeuw & & & & $0 / 0 / 15$ & $102 / 0 / 10$ \\
\hline Grote stern & $34 / 0 / 0$ & $0 / 0 / 1$ & $5 / 0 / 0$ & $1 / 0 / 0$ & \\
\hline Zeekoet & & & $0 / 2 / 2$ & $1 / 0 / 2$ & $4 / 4 / 0$ \\
\hline Alk & & & & & $1 / 0 / 0$ \\
\hline Graspieper & & & & $30 / 0 / 0$ & $6 / 0 / 5$ \\
\hline Zangvogel ongedet. & & & & $3 / 0 / 0$ & \\
\hline Spreeuw & & & & & $12 / 9 / 0$ \\
\hline
\end{tabular}

\subsection{Verstoringen tijdens het onderzoek}

De vogels waren niet altijd vrij in hun keuze om bepaalde fundaties te bezoeken. Onze vogelobservaties werden verricht bij goed weer en deze "weer-windows" werden ook steeds benut door onderhoudsploegen om turbines te bezoeken. Verschillende vormen van verstoring werden tijdens de surveys (systematisch) genoteerd: een onderzoeksschip gemeerd aan, of met een touw verbonden aan een turbinefundatie; mensen aan boord van de turbine (zichtbaar aanwezig of kennelijk aanwezig doordat de deur in de fundatie open stond of er materiaal zoals hijstassen op het bordes stonden); schoonmaakwerkzaamheden: tijdens de survey in juli werd er ook reinigingswerk verricht op het bordes van enkele windmolens met hogedruk apparatuur, die werd gevoed via een slang uit zee; of onderhoud aan de stilstaande wieken van molens, door mensen hangend aan een wiek). Stilstand van de molen werd ook genoteerd, maar indien dit niet gepaard ging met "mensen aan boord" werd dit niet opgevat als een verstoring: stilstand kon ook het gevolg zijn van windstilte of van een defect aan de molen. Stilstand op zich leek geen negatief effect te hebben op de aanwezigheid van vogels op of bij de fundatie; "mensen aan boord" of een aangemeerd schip hadden dit wel. Bij dergelijke verstoringen waren er nooit vogels aanwezig op de betreffende turbinefundatie, met één uitzondering: tijdens de augustustelling waren er mensen aan het werk op molen \#7 in park Luchterduinen. Desondanks rustten twee volwassen Grote mantelmeeuwen op deze molen. In alle overige gevallen van verstoring door mensen en schepen op of aan de turbines werden op de betreffende turbinefundaties geen vogels gezien. In de verspreidingskaarten staan de "verstoorde molens" gemerkt: op geen enkele van deze fundaties werden rustende vogels gezien op momenten waarop sprake was van verstoring. Wel vlogen vogels soms op geringe afstand langs of zwommen er vogels in zee in de buurt van verstoorde molens. 


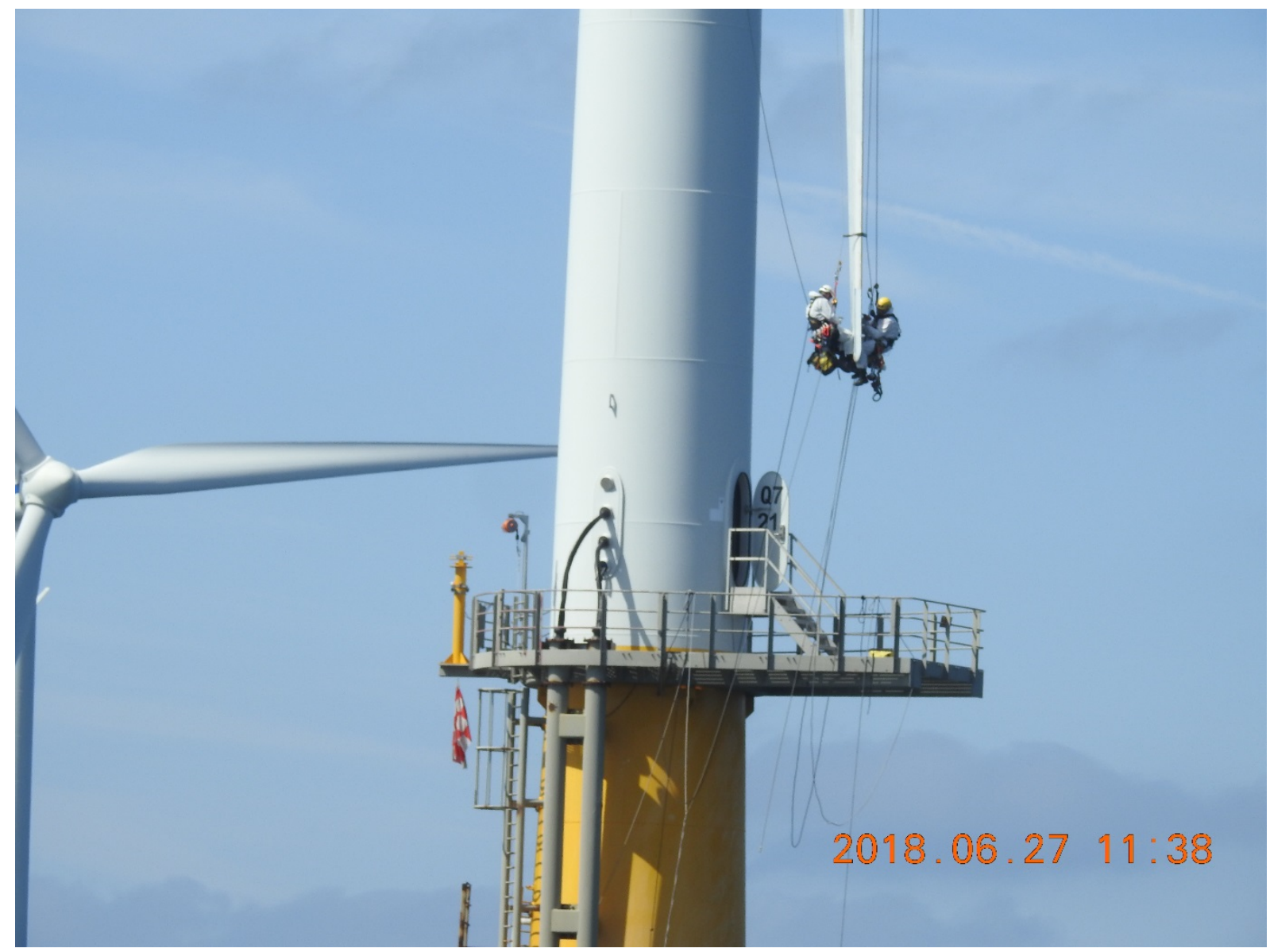

Figuur 2. Onderhoudspersoneel tijdens een acrobatische sessie aan een wiektip van molen 21, in PAWP, 27 juli 2018. Om in deze positie te komen zijn de mannen vanuit de nacelle afgedaald langs de wiek.

Er werden, in alle parken, ook permanente vormen van verstoring waargenomen die bedoeld leken om vogels te ontmoedigen om te rusten op de fundaties. Navraag leerde dat de vogelpoep die de vogels op de installaties deponeren door onderhoudspersoneel als een serieus probleem en veiligheidsrisico wordt gezien, zeker na eerdere uitbraken aviaire influenza (vogelgriep) (Sytske van den Akker, Eneco, pers. comm.). Op de relingen van de bordessen van sommige molens van OWEZ en PAWP waren op regelmatige afstanden tie-rips aangebracht, met het losse eind omhoog gericht. Het aantal aangebrachte tie-rips verschilde sterk van molen tot molen, van geen tot "alle relingen helemaal vol". Elders dunne draadjes gespannen over relingen heen. Er was tijdens de surveys onvoldoende gelegenheid om goed vast te leggen waar en hoeveel tie-rips of draadjes waren aangebracht en deze waren ook niet onder alle omstandigheden goed te zien. Of er dus een ontwikkeling was in de aantallen van deze aangebrachte voorzieningen, en of er een navenante ontwikkeling was in de aantallen rustende vogels op de molens met deze voorzieningen, is niet bekend. Er werden overigens regelmatig rustende vogels op deze molens gezien, zowel tussen de tie-rips, als bovenop de gespannen draadjes, als op zitplaatsen elders op de zelfde molen, die vrij waren van vogelwerende voorzieningen.

Op molen PWAP \# 48 was op een reling een metalen "verjaagkraai" aangebracht (figuur 3 ) en op molen PAWP \# 55 waren enkele reflecterende draaimolentjes op de reling bevestigd (figuur 4). Deze twee laatste molens waren overigens opvallend populair bij aalscholvers om er te rusten.

Op het OHVS van PAWP is op het dak een vogelverschrikker geplaatst. Deze bleek ook niet in staat om alle vogels te verhinderen op dit platform te rusten (figuur 5). 


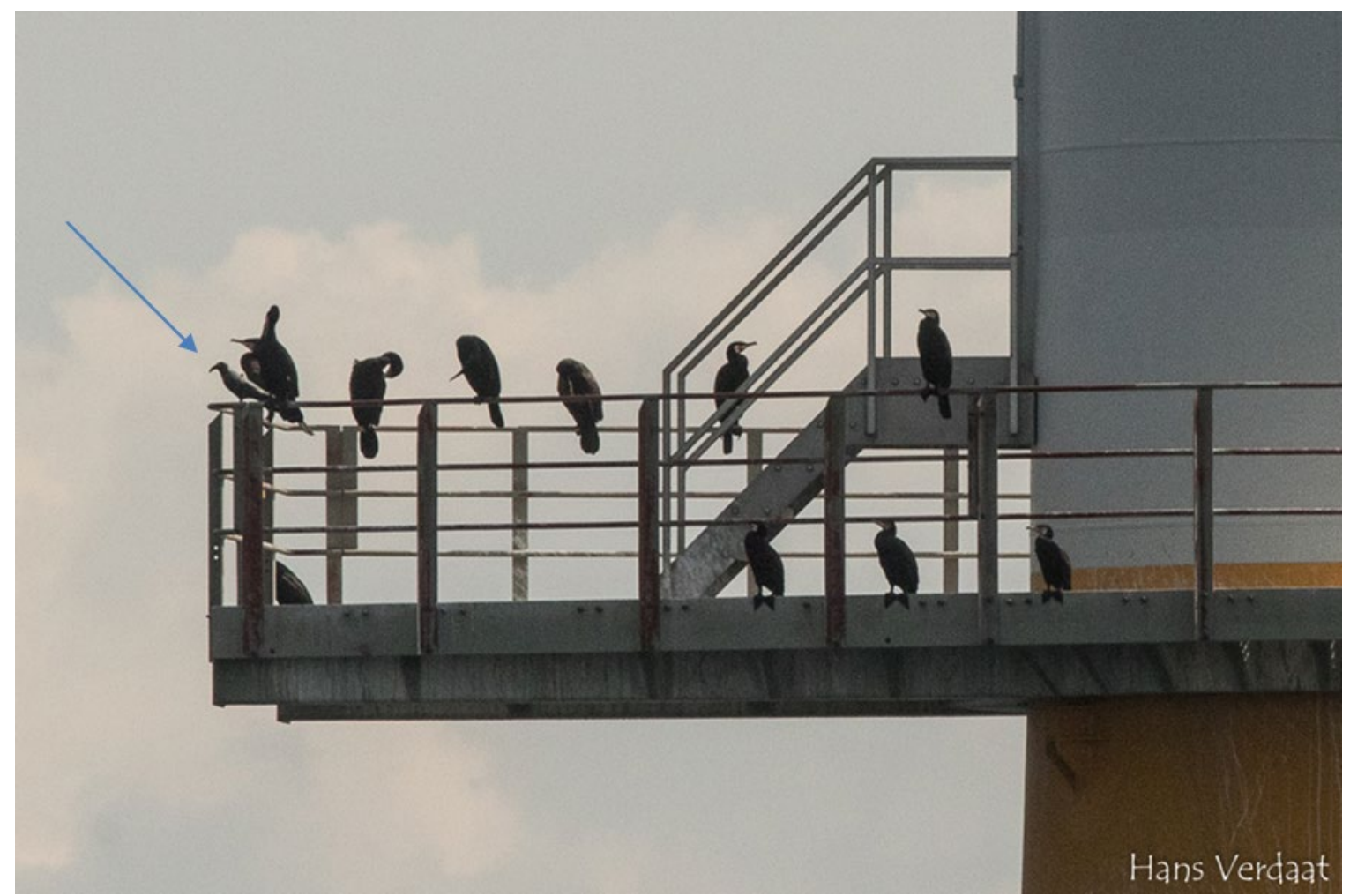

Figuur 3. Metalen verjaagkraai (aangewezen door de pijl) op molen PWAP \# 48, gefotografeerd op 29 augustus 2018, omgeven door rustende aalscholvers.

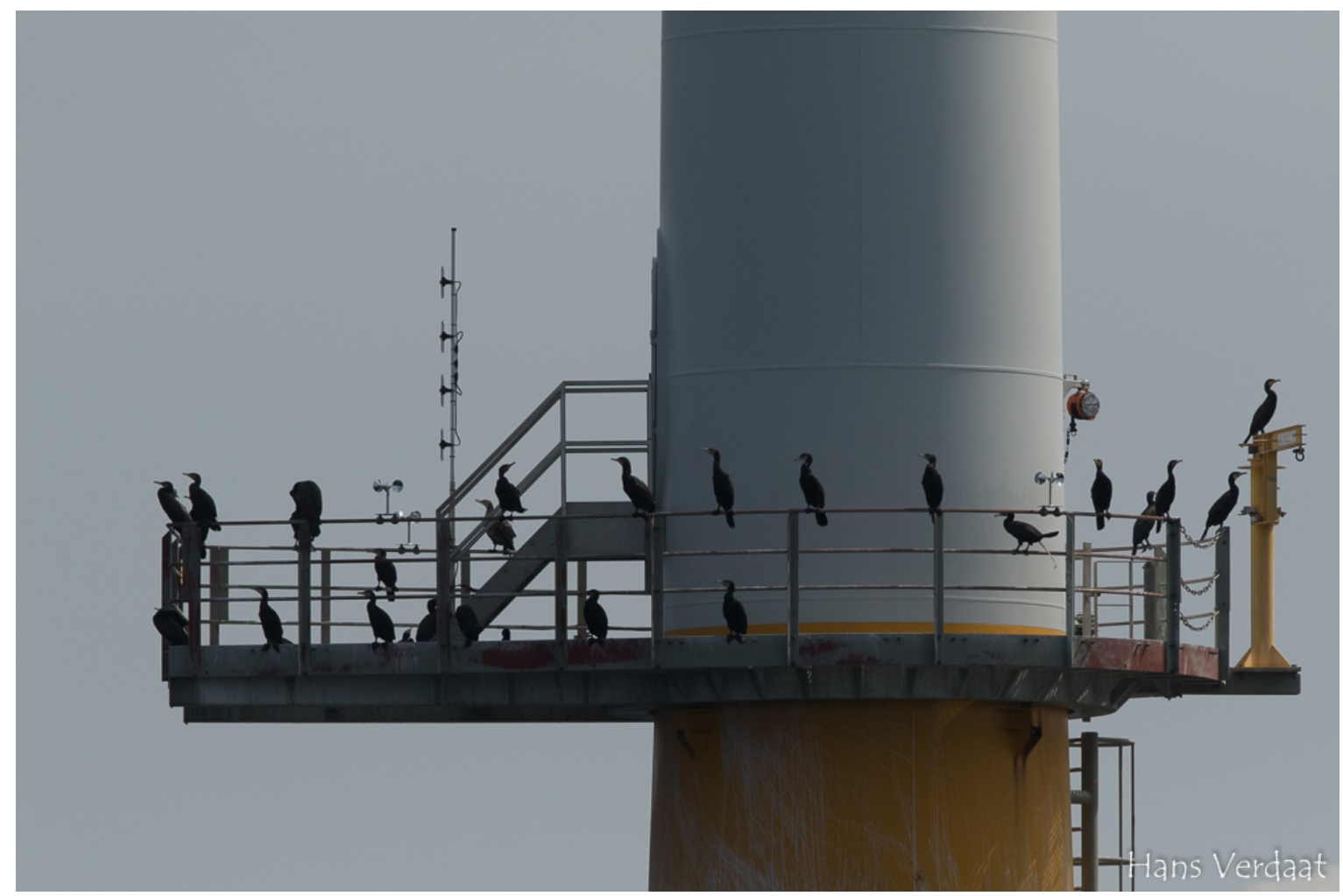

Figuur 4. Drie draaimolentjes op molen PAWP \# 55, gefotografeerd op 19 juli 2018, omgeven door rustende aalscholvers. 


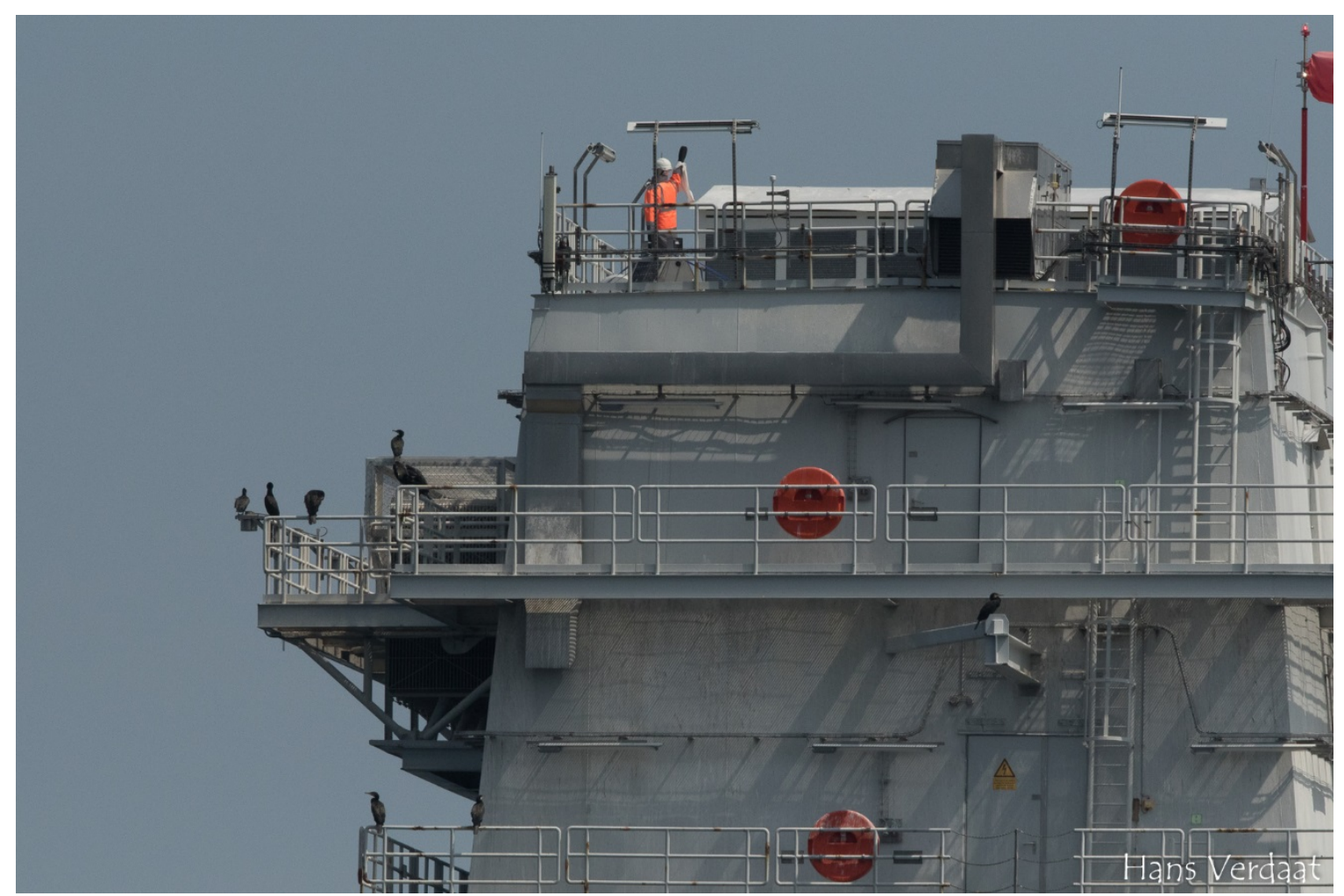

Figuur 5. Vogelverschrikker op het dak van het OHVS van PAWP, gefotografeerd op 29 augustus 2018. Eén en twee dekken lager rustten op dat moment 38 aalscholvers en een grote mantelmeeuw.

Tenslotte zijn er, in de zomer van 2018, op het bordes van molen \# 42 in LUD twee vogelradars geïnstalleerd: een horizontale en verticale radar (figuur 6; Gyimesi 2018). Deze werden voor het eerst opgemerkt tijdens de survey van 29 september. In hoeverre deze radars vogels weg houden van deze turbine is niet duidelijk, maar op deze molen werden tijdens de surveys in september en in oktober geen rustende vogels gezien, maar tijdens de drie eerdere surveys evenmin (tijdens de survey in augustus werd op deze molen onderhoud gepleegd). 


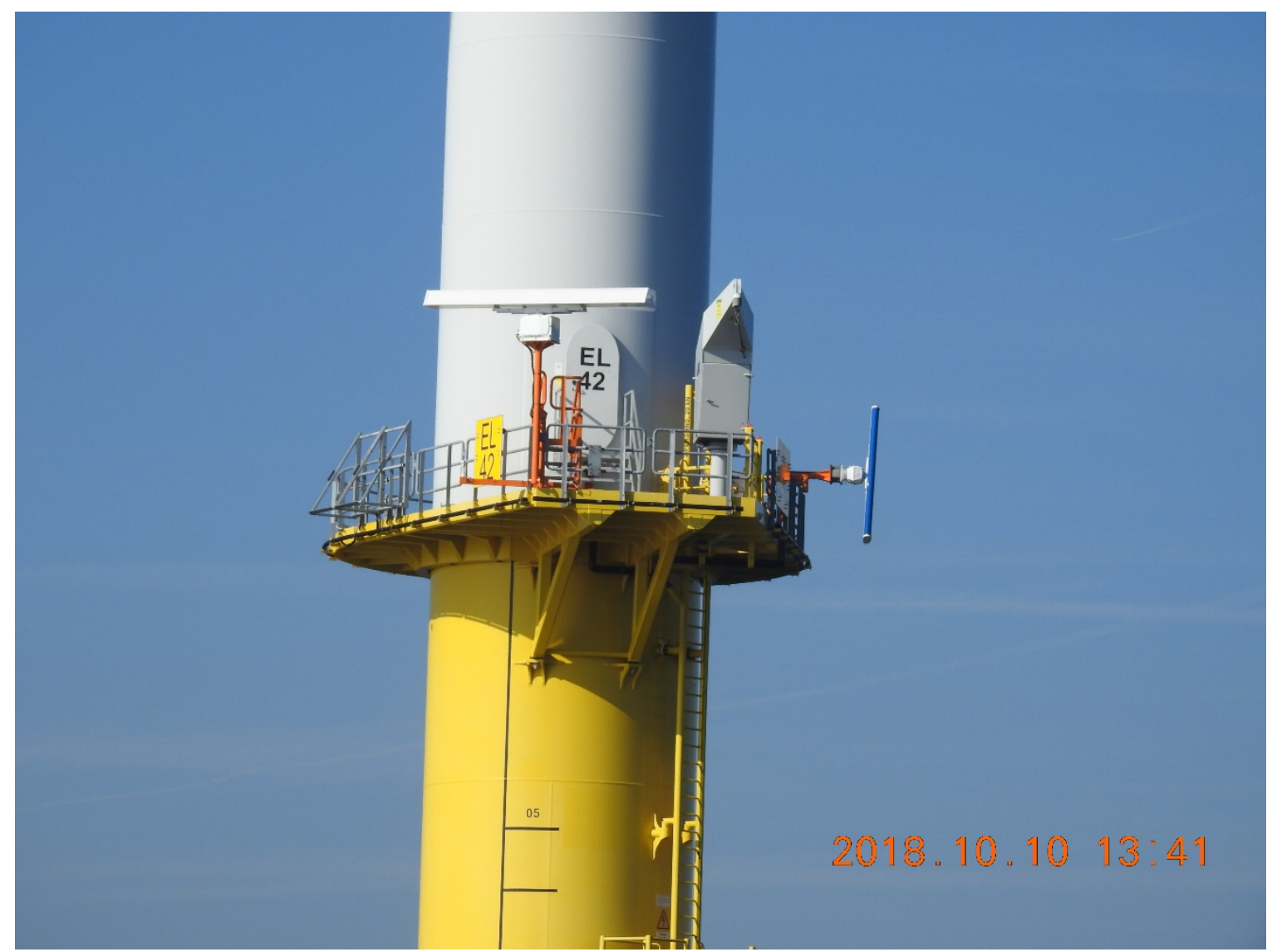

Figuur 6. Vogelradars op molen LUD \# 42, gefotografeerd op 10 oktober 2018.

\subsection{Soortbesprekingen}

Voor alle waargenomen soorten (vogels en zeezoogdieren) zijn verspreidingskaarten gemaakt (zie bijlage). Voor de vier meest waargenomen vogelsoorten aalscholver, kleine mantelmeeuw, zilvermeeuw en grote mantelmeeuw zijn bovendien samenvattende kaarten gemaakt voor de hele surveyperiode. Hieronder worden eerst de meest talrijk waargenomen soorten besproken (aalscholver, grote meeuwen en drieteenmeeuw) en vervolgens de minder talrijke.

\subsubsection{Aalscholver}

Aalscholvers waren de talrijkste vogels in alle windparken, tijdens alle vijf de surveys. In totaal werden er 3161 aalscholvers geteld, $78.6 \%$ van alle getelde vogels (ook tijdens de drie wintersurveys was de aalscholver de meest talrijke soort, toen was hun aandeel $51.6 \%$ over drie surveys). Het grootste aantal aalscholvers werd geteld op de meetmast van OWEZ (198 vogels in oktober); deze meetmast was tijdens alle surveys, in alle parken steeds het object waarop zich de meest aalscholvers bevonden. Er werd ook veelvuldig gerust op de turbinefundaties. Tijdens alle surveys werden tot tientallen vogels geteld op enkele afzonderlijke turbine fundaties, in ieder park. Foeragerende (zwemmende en duikende) aalscholvers werden ook meermalen waargenomen. Dit betrof zowel enkelingen als groepen en er werd zowel vlak bij turbine fundaties gedoken als verder weg van de turbines, in "open" water. Molens in de nabijheid van de meetmast van OWEZ, maar ook molens in de nabijheid van het OHVS van LUD trokken relatief veel rustende aalscholvers (figuur 7). In alle drie de parken rustten de meeste aalscholvers op molens aan de periferie, waarbij soms bepaalde delen van de periferie de meeste voorkeur leken te hebben: de zuidrand en de noordoosthoek van LUD; de noordwesthoek van OWEZ en de oostelijke rand van PAWP (figuur 7). Over meerdere surveys gesommeerd, leek verstoring van molens op deze patronen weinig invloed te hebben. 

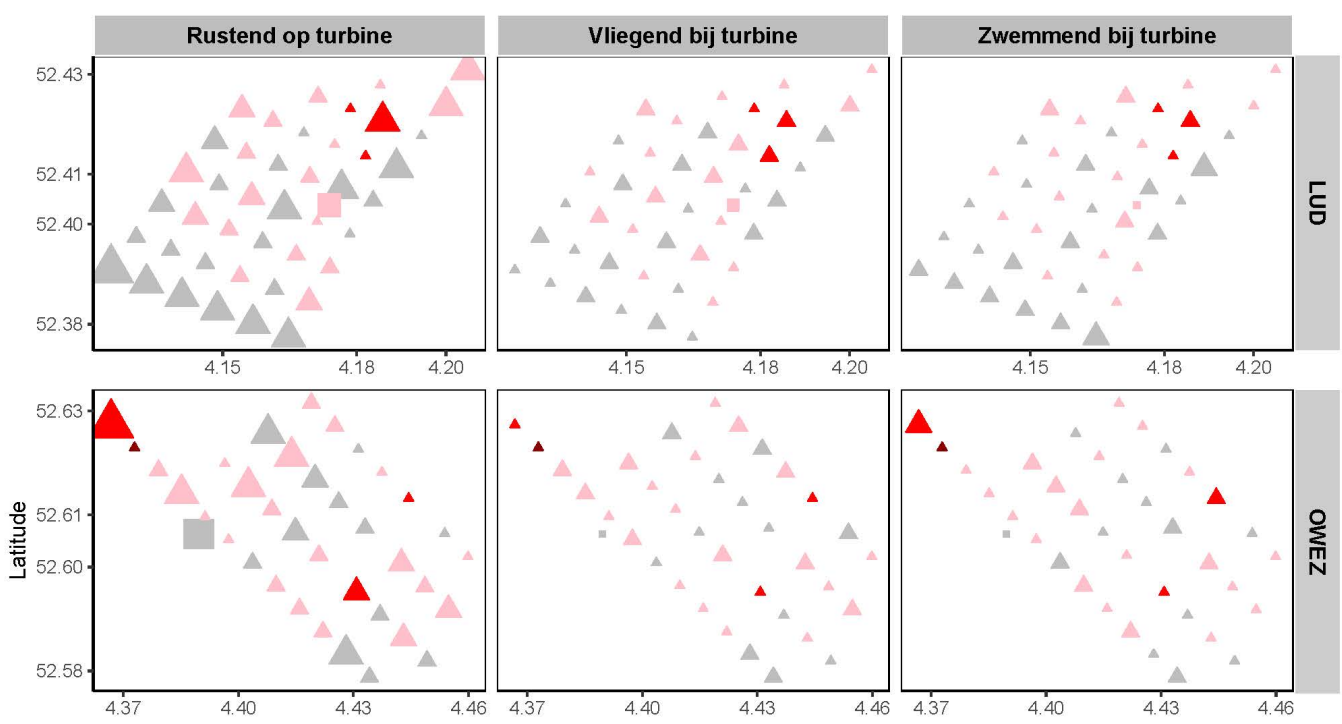

Meetmast

$\square$ OHVS

$\triangle$ Windturbine
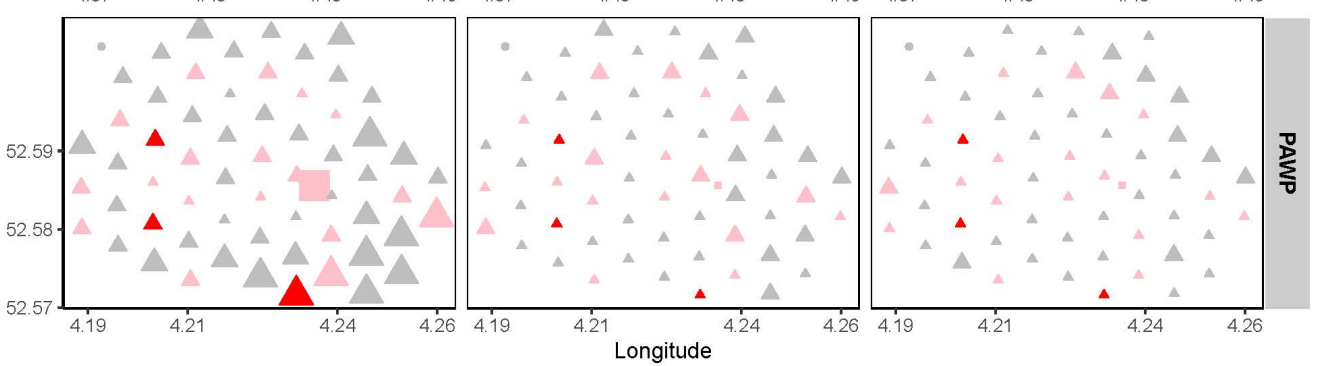

Aantal keer verstoord

- 0

1

- 2

- 4

Aantal vogels $\triangle 0$

Figuur 7. Aantallen rustende (links) aalscholvers op de verschillende molens (etc) in LUD, OWEZ en PAWP (van boven naar beneden) en de aantallen vliegende (midden) en zwemmende (rechts) aalscholvers in deze parken, geplot op de dichtstbijzijnde molen, cumulatief over alle vijf surveys. De verschillende kleuren geven de mate van verstoring van de molens weer, in aantal malen verstoord (maximum vijf keer: verstoord bij alle vijf surveys).

In OWEZ en in PAWP waren respectievelijk de meetmast en het OHVS altijd favoriet voor rustende aalscholvers: gemiddeld werden hier de hoogste aantallen geteld en de standaarddeviatie rond het gemiddelde was lager dan het gemiddelde (figuur 8). Het OHVS van LUD werd in dit opzicht minder gebruikt door rustende aalscholvers. Sommige molens, waaronder de molens PWAP \# 48 (met de "verjaagkraai") en molen PAWP \# 55 (met draaimolentjes) waren veel en vaak bezocht door rustende aalscholvers: gemiddeld hoge aantallen en relatief lage standaarddeviaties. Andere molens waren juist weinig in trek: veel van deze niet of nauwelijks bezochte molens bevonden zich relatief centraal in de verschillende windparken. 


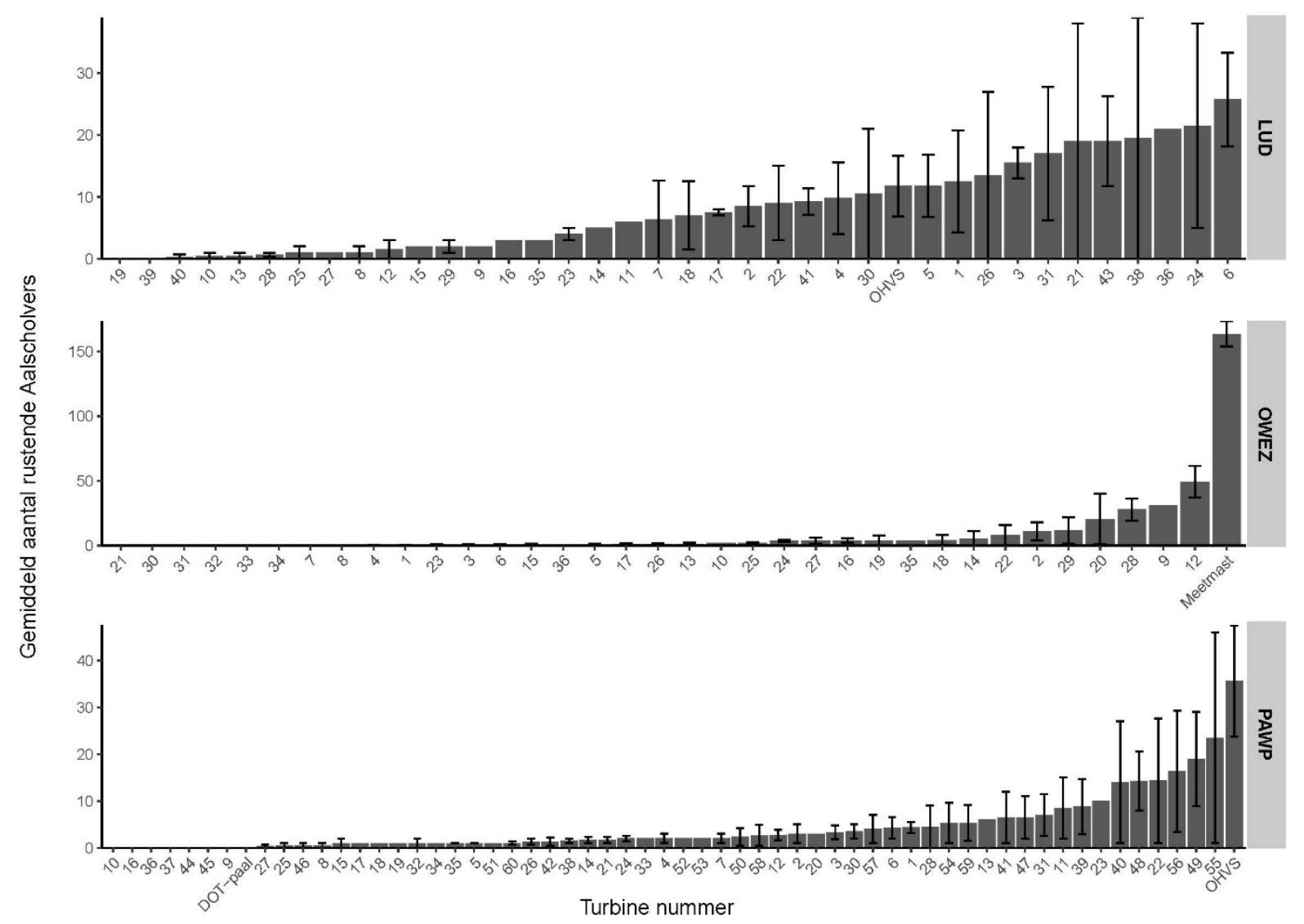

Figuur 8. Gemiddelde ( \pm standaarddeviaties) aantallen rustende aalscholvers op de verschillende molens (etc) van de windparken LUD, OWEZ en PAWP, over de vijf surveys.

Hoewel van aalscholvers bekend is dat ze vissersschepen volgen (Camphuysen 1999) en ze dus wellicht ook wel bij bootjes met hengelaars zouden kunnen komen kijken, kwam geen enkele aalscholver op het onderzoeksschip af tijdens de standaard 15 minuten lange hengelsessies in de parken. Ook bij de (schaars aanwezige) bootjes met hengelaars in de windparken werd geen enkele aalscholver gezien.

Vliegende aalscholvers in de windparken werden meest gezien op hoogtes 3 (10-25m boven het water) en 4 (25-50m boven het water), of lager. Over alle vijf surveys werd $61 \%$ van alle vliegende waargenomen aalscholvers in de parken gezien onder rotorhoogte (hoogtes 1-3) en 39\% op rotorhoogte (figuur 9). Aalscholvers die werden opgejaagd van hun rustplaatsen kozen het luchtruim door zich van bijvoorbeeld het bordes van een molen omlaag te storten om zo snelheid te winnen. Aanvankelijk bevonden al deze verstoorde vogels zich dus beneden rotorhoogte (de bordessen bevinden zich op $17 \mathrm{~m}$ boven het water, de tip van wieken reikt tot $25 \mathrm{~m}$ boven het water). Vogels waarvan duidelijk was dat ze werden verjaagd, hetzij door aankomend onderhoudspersoneel, hetzij (in de meeste gevallen) doordat het onderzoeksschip de molen naderde) zijn genoteerd als "rustend" en zijn dus in figuur 9 niet meegenomen). 


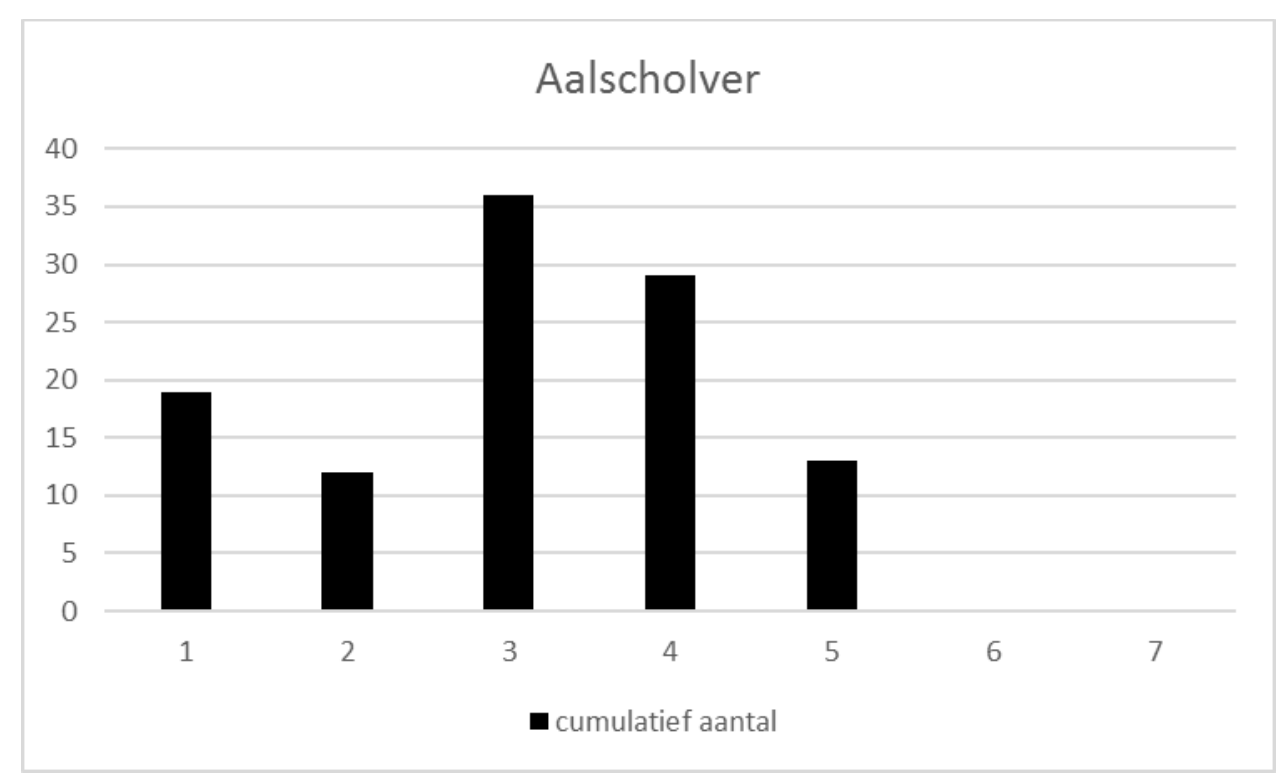

Figuur 9. De hoogtes boven het water (cumulatief over de vijf surveys) waarop aalscholvers vliegend door de windparken werden gezien. Hoogteklassen 1-7: $1=0-2 m ; 2=2-10 m ; 3=10-25 m ; 4=25-$ 50m; $5=50-100 m ; 6=100-200 m ; 7=>200 m$ (geschat).

\subsubsection{Zilvermeeuw}

In totaal werden er tijdens de vijf surveys in de drie parken 63 zilvermeeuwen waargenomen. De meeste vogels werden rustend op een turbine waargenomen (39). Vliegend door de parken werden in totaal 11 vogels genoteerd en zwemmend tussen de fundaties 13. Vogels rustten zowel op molens langs de rand van de parken als centraal in het park (figuur 10). In LUD rustten de meeste zilvermeeuwen op fundaties in de noordelijke helft van het park; in OWEZ werd nooit gerust op turbines langs de noordoostrand van het windpark en in PAWP was er geen duidelijk patroon. Op slechts een minderheid van de molens werden rustende zilvermeeuwen gezien en zelden ( $1 \times 2$ en $1 \times 3$ vogels) rustten meerdere vogels samen op dezelfde turbinefundatie (figuur 10, 12). Vliegende en zwemmende vogels werden her en der in de verschillende parken gezien, zonder een duidelijke voorkeur voor bepaalde delen van de parken. In elk van de drie parken werd één vliegende zilvermeeuw gezien die kort afweek van zijn route om even achter het onderzoeksscheepje te komen kijken. In LUD gingen twee zilvermeeuwen (samen met enkele grote mantelmeeuwen) achter een slechtvalk aan die met een prooi in de klauwen rond vloog in het park. De meeste van de waargenomen vliegende zilvermeeuwen vlogen onder rotorhoogte door de parken; de twee vogels die achter de slechtvalk aangingen bereikten de grootste hoogte boven zeeniveau (figuur 11).

Een van de (volwassen) zilvermeeuwen die we in OWEZ rustend op een van de fundaties aantroffen bleek gekleurringd (groen-Y.CAW): een broedvogel uit de kolonie op het Forteiland bij de sluizen IJmuiden.

De hengelsessies brachten geen enkele zilvermeeuw naar het onderzoeksschip, we zagen geen enkele reactie van zilvermeeuwen op ons vissen. 

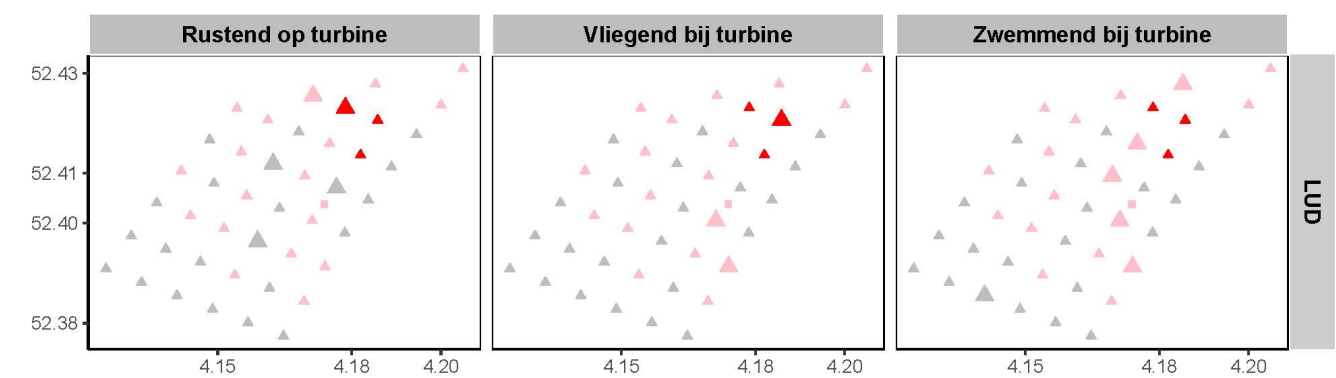

O DOT-paal

$\square$ Meetmast

$\square$ OHVS
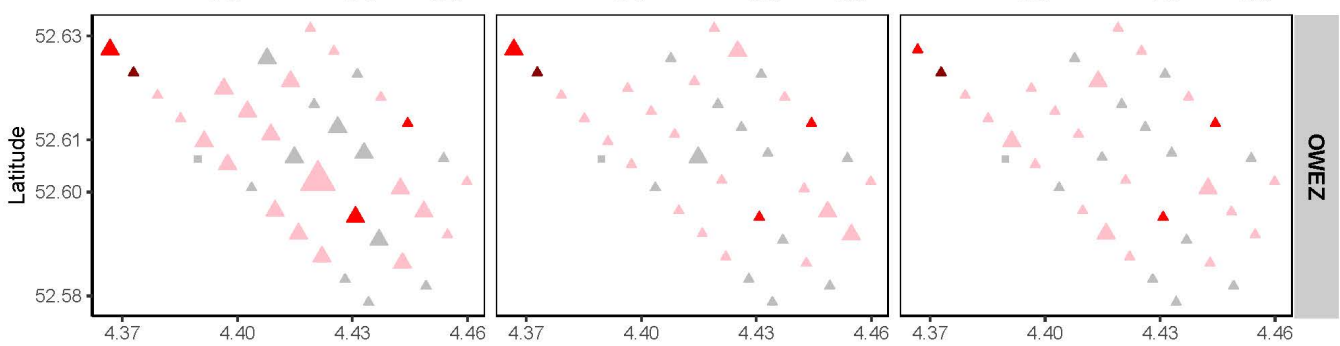

$\triangle$ Windturbine
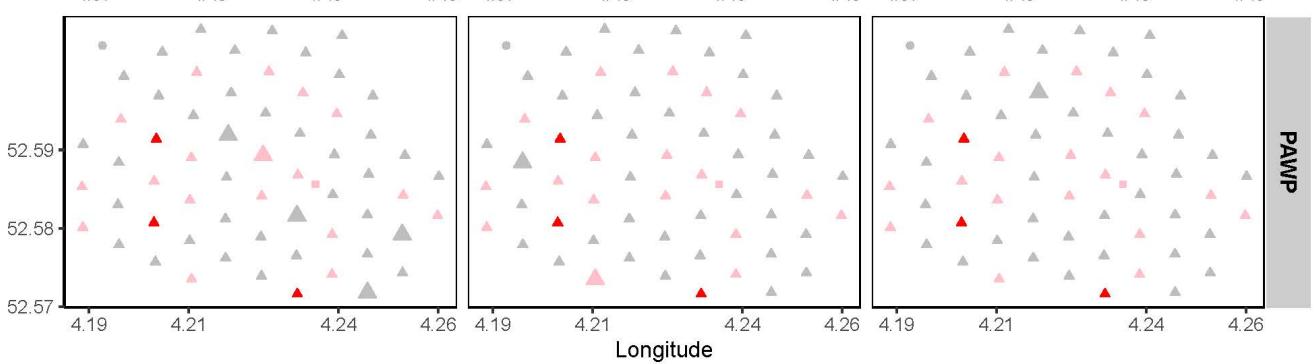

Figuur 10. Aantallen rustende (links) zilvermeeuwen op de verschillende molens (etc) in LUD, OWEZ en PAWP (van boven naar beneden) en de aantallen vliegende (midden) en zwemmende (rechts) vogels in deze parken, geplot op de dichtstbijzijnde molen, cumulatief over alle vijf surveys. De verschillende kleuren geven de mate van verstoring van de molens weer, in aantal malen verstoord (maximum vijf keer: verstoord bij alle vijf surveys).

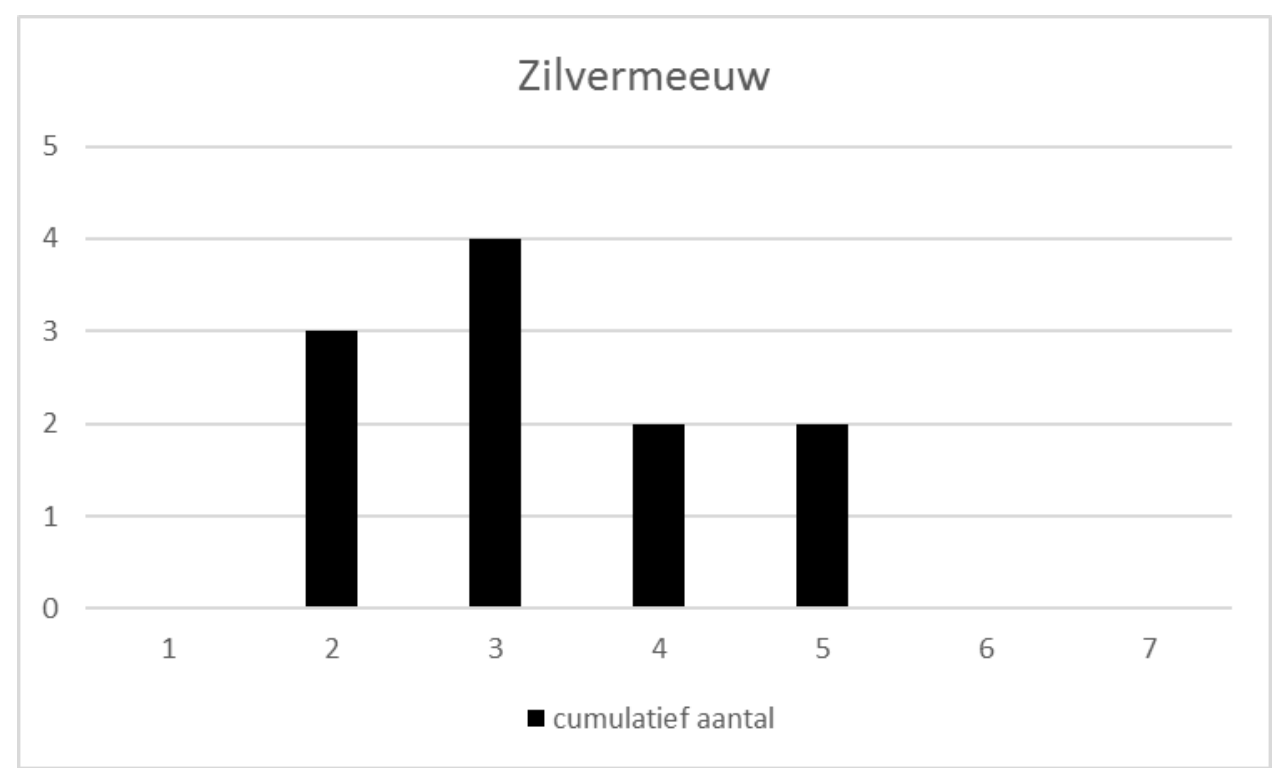

Figuur 11. De hoogtes boven het water (cumulatief over de vijf surveys) waarop zilvermeeuwen vliegend door de windparken werden gezien. Hoogteklassen 1-7: $1=0-2 \mathrm{~m} ; 2=2-10 \mathrm{~m} ; 3=10-25 \mathrm{~m} ; 4$ = 25-50m; $5=50-100 m ; 6=100-200 m ; 7=>200 m$ (geschat). 


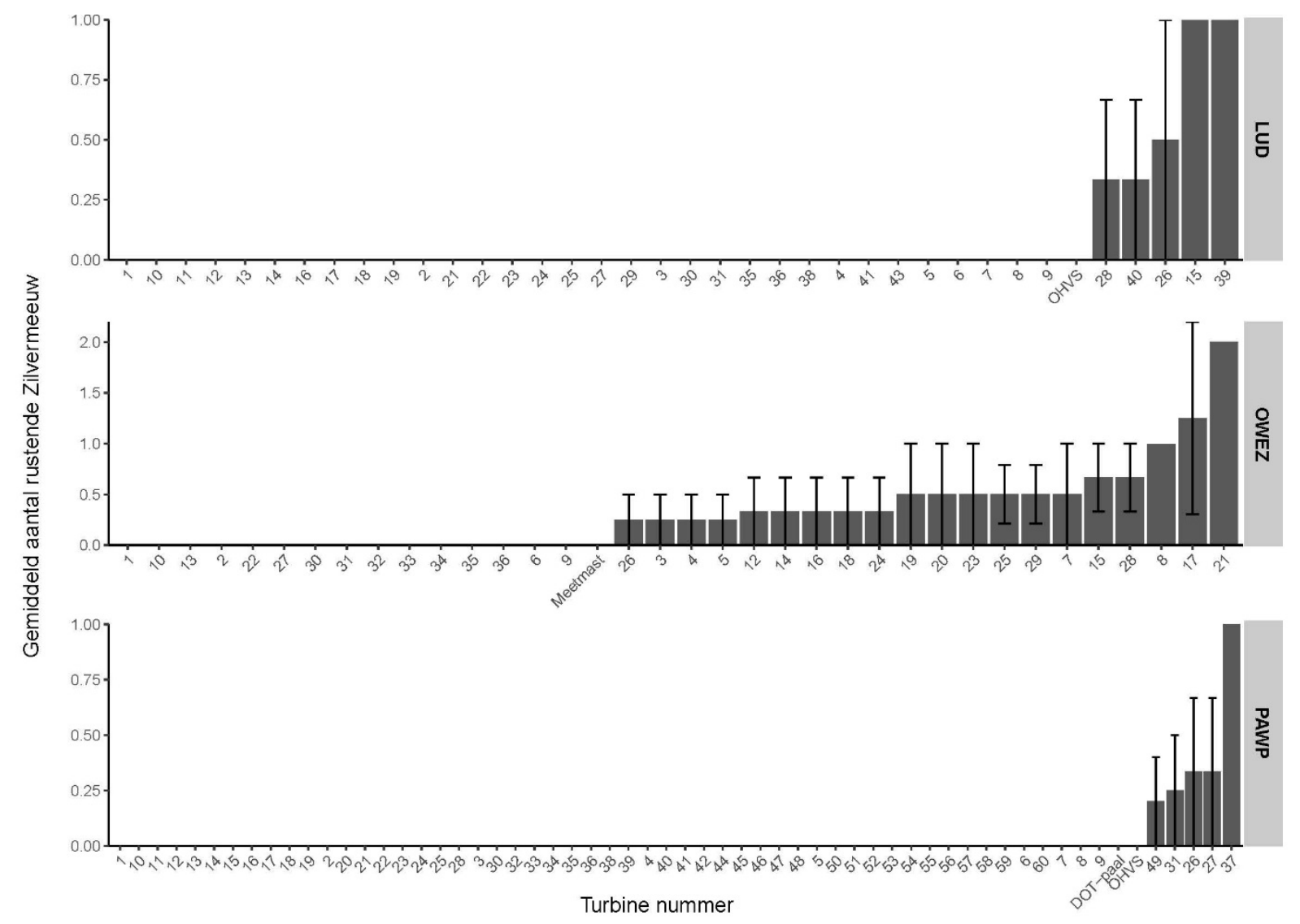

Figuur 12. Gemiddelde ( \pm standaarddeviaties) aantallen rustende zilvermeeuwen op de verschillende molens (etc) van de windparken LUD, OWEZ en PAWP, over de vijf surveys.

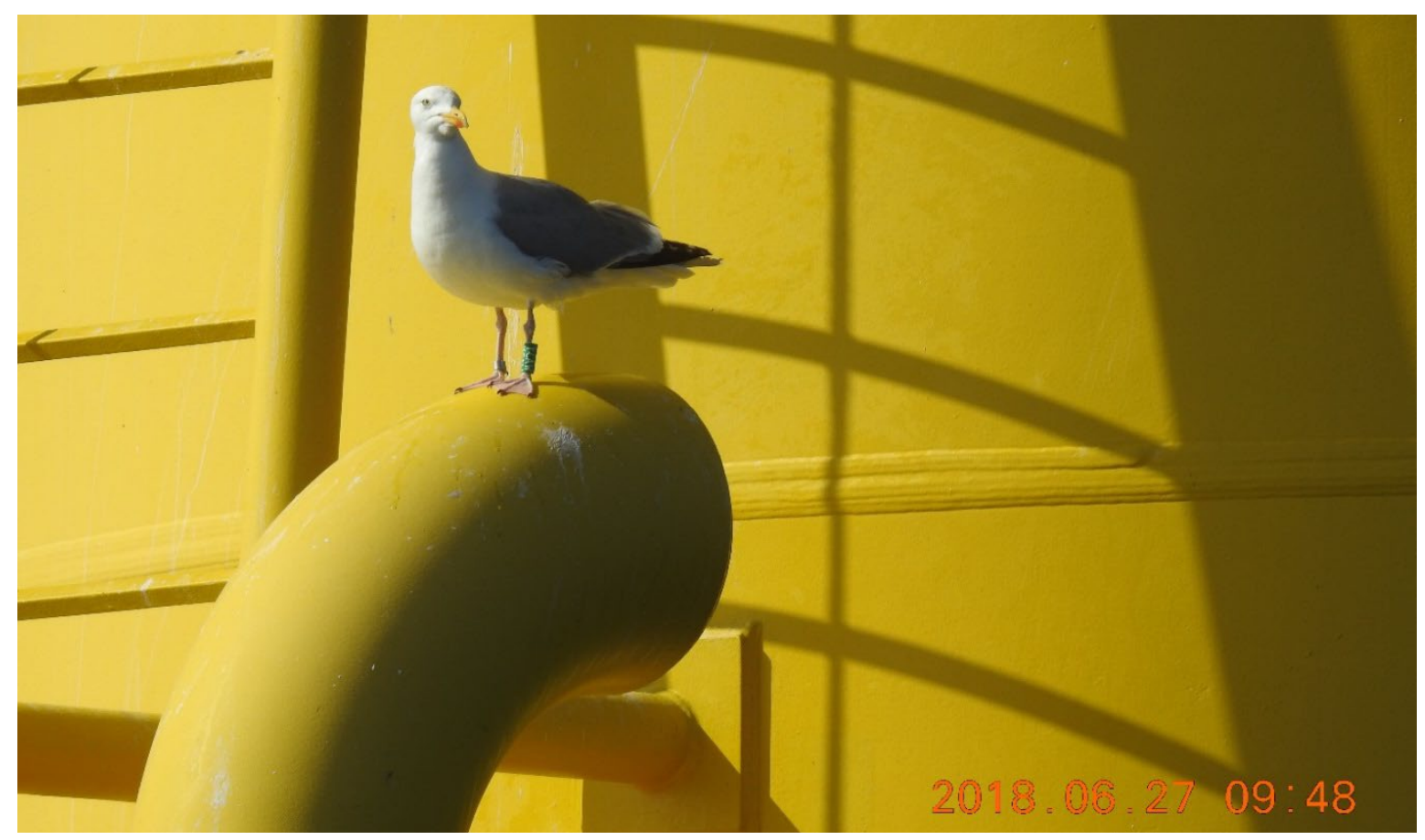

Figuur 13. Zilvermeeuw Groen-Y.CAW, rustend op turbinefundatie \#4 in OWEZ, 27 juni 2018. 


\subsubsection{Kleine mantelmeeuw}

In totaal werden er tijdens de vijf surveys in de drie parken 87 kleine mantelmeeuwen waargenomen, meest in de zomermaanden juni-augustus (Tabel 2). In tegenstelling tot zilvermeeuwen werd slecht een minderheid van de kleine mantelmeeuwen ( 8 vogels: 1 in juni, op de OWEZ meetmast; twee in juli: op turbinefundaties OWEZ \#31 en PAWP \#4; vier in september: op turbinefundaties OWEZ \#7 en 24, PAWP \#57 en op het OHVS van PAWP; en 1 in oktober, op turbinefundatie PAWP \#39 ) rustend op turbinefundaties en op een OHVS (1x) gezien; de meeste vogels werden vliegend door de parken (71) gezien. Acht vogels werden zwemmend tussen de fundaties op zee genoteerd.

Met slechts acht vogels die rustend op turbines werden waargenomen is er geen duidelijke voorkeur aan te geven voor rusten op perifere, dan wel meer centraal geplaatste molens (figuur 14). Ook voor de vliegende en zwemmende kleine mantelmeeuwen is geen voorkeur aan te geven voor bepaalde delen van de parken. Drie van de vliegend waargenomen kleine mantelmeeuwen waren duidelijk gericht op het water: vermoedelijk zoekend naar prooi. Twee andere vogels doken van enige hoogte het water in en probeerden iets met hun snavel te pakken. In elk van de drie parken werd één (of twee) vliegende kleine mantelmeeuw(en) gezien die kort afweek van zijn route om even achter het onderzoeksscheepje te komen kijken (vier vogels in totaal). De meeste van de waargenomen vliegende zilvermeeuwen vlogen op rotorhoogte door de parken (84.5\%); slechts $15.5 \%$ vloog op lagere hoogtes boven zee (figuur 15 ).

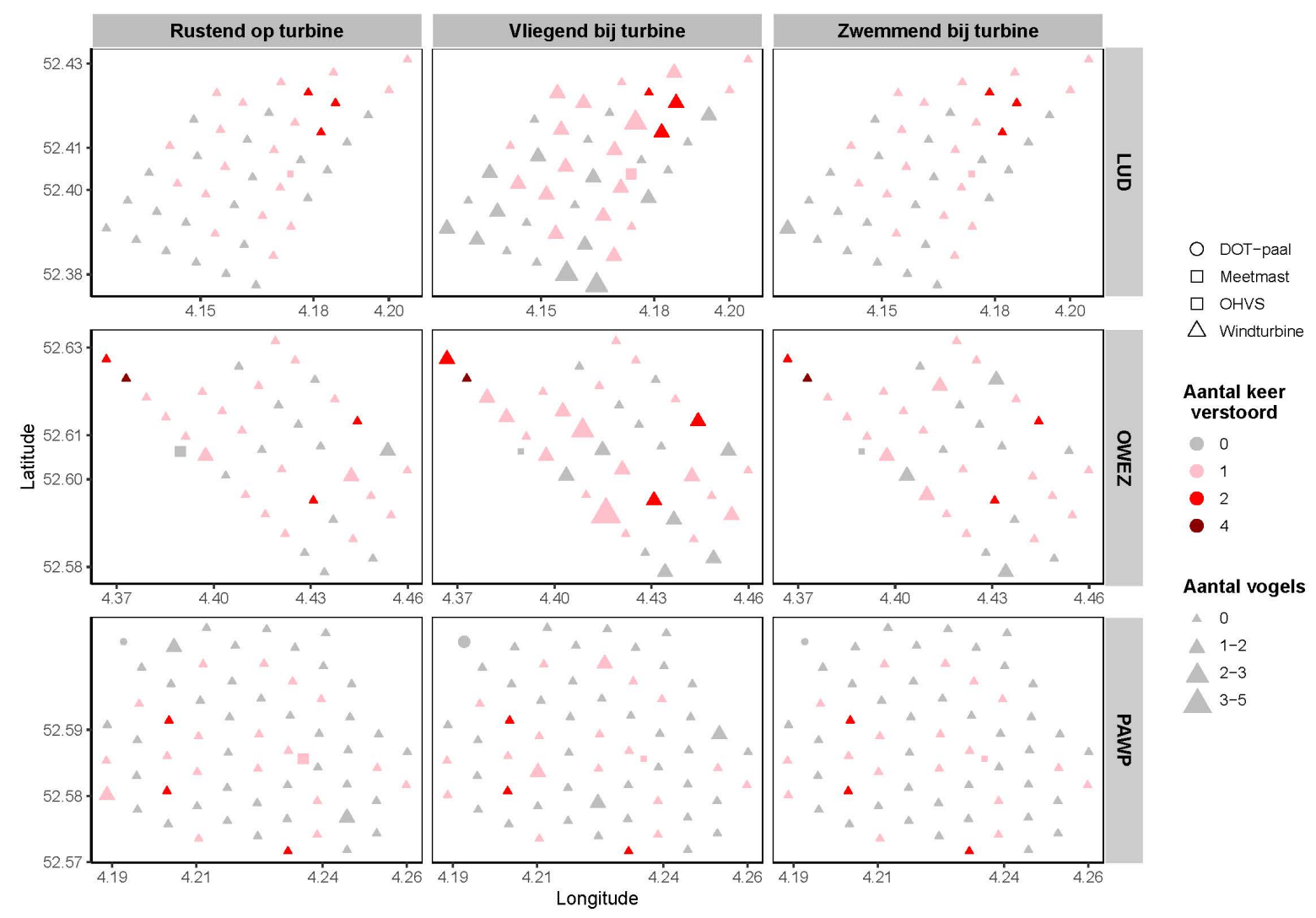

Figuur 14. Aantallen rustende (links) kleine mantelmeeuwen op de verschillende molens (etc) in LUD, OWEZ en PAWP (van boven naar beneden) en de aantallen vliegende (midden) en zwemmende (rechts) vogels in deze parken, geplot op de dichtstbijzijnde molen, cumulatief over alle vijf surveys. De verschillende kleuren geven de mate van verstoring van de molens weer, in aantal malen verstoord (maximum vijf keer: verstoord bij alle vijf surveys).

De hengelsessies brachten geen enkele kleine mantelmeeuw naar het onderzoeksschip, we zagen geen enkele reactie van deze soort op ons vissen. 


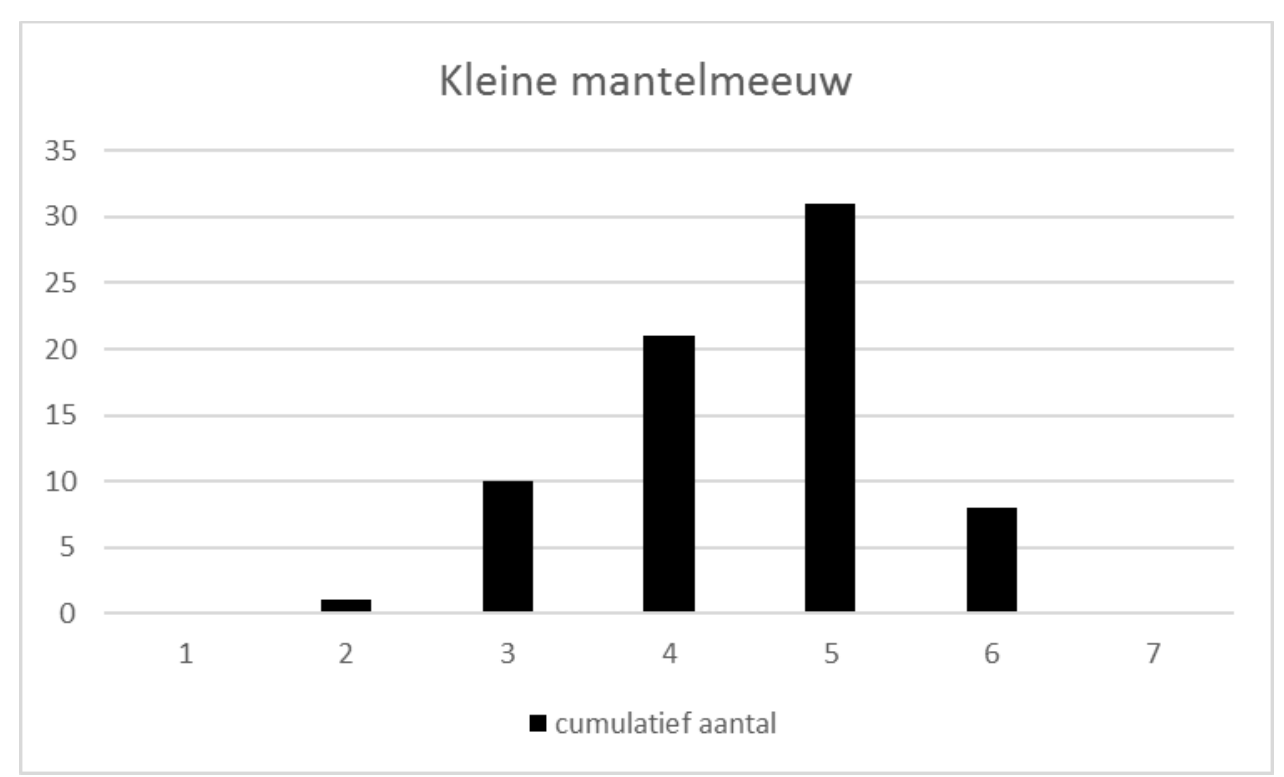

Figuur 15. De hoogtes boven het water (cumulatief over de vijf surveys) waarop kleine mantelmeeuwen vliegend door de windparken werden gezien. Hoogteklassen 1-7: $1=0-2 m ; 2=2-10 m ; 3=10-25 m ; 4$ = 25-50m; $5=50-100 m ; 6=100-200 m ; 7=>200 m$ (geschat).

\subsubsection{Grote mantelmeeuw}

In totaal werden er tijdens de vijf surveys in de drie parken 402 grote mantelmeeuwen waargenomen, meest in de herfst (Tabel 2). Ruim de helft van alle grote mantelmeeuwen (214) rustend op turbinefundaties, op de OHVS (29 vogels in totaal) en op de meetmast van OWEZ gezien ( $2 \times 1$ en $1 \times 2$ vogels). In totaal werden 82 vogels vliegend door de parken gezien en 106 vogels werden zwemmend tussen de fundaties op zee genoteerd. Grote mantelmeeuwen werden op de meeste turbinefundaties wel eens rustend gezien (figuur 16, 18). De twee OHVS's waren met afstand de meest favoriete locaties.

In windpark LUD leken de rustende grote mantelmeeuwen een voorkeur te hebben voor molens aan de perifere van het park, in de beide andere parken was dit minder duidelijk. Wel rustten opvallend weinig grote mantelmeeuwen op fundaties langs de noord- en oostrand van OWEZ (figuur 16). Voor de vliegende en zwemmende grote mantelmeeuwen is geen duidelijke voorkeur aan te geven voor bepaalde delen van de parken. In totaal vijf grote mantelmeeuwen kwamen tijdens de surveys even achter het onderzoeksscheepje (snelheid: 10 knopen) aanvliegen voor een korte inspectie. Drie grote mantelmeeuwen gingen, samen met twee zilvermeeuwen, achter een slechtvalk aan die in LUD rond vloog. De meeste van de waargenomen vliegende zilvermeeuwen vlogen op rotorhoogte door de parken (65\%); een derde vloog op lagere hoogtes boven zee en een vogel ruim boven rotorhoogte (figuur 15). Tijdens een van de hengelsessies kwamen twee (juveniele) grote mantelmeeuwen naar het onderzoeksschip, en streken op enkele tientallen meters naast het schip op het water neer. 

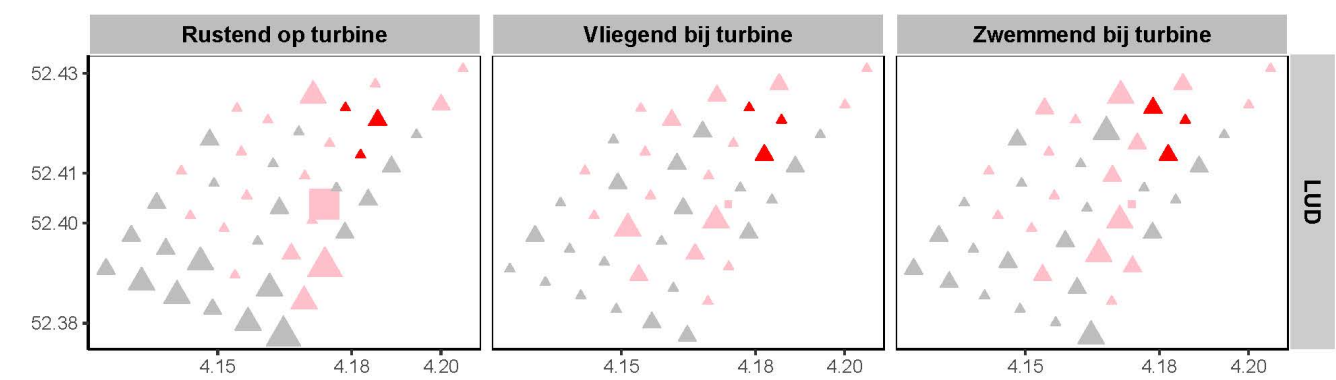

듬
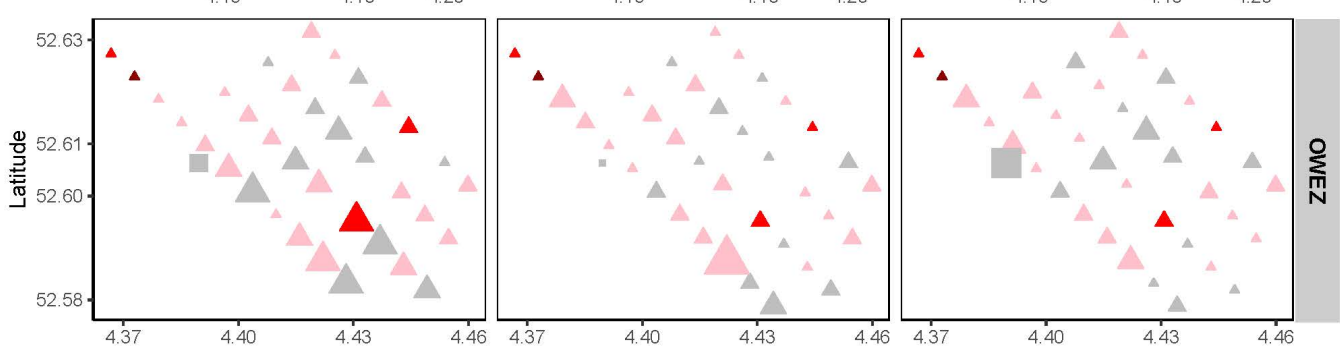

$\square$ Meetmast

$\square$ OHVS

$\triangle$ Windturbine
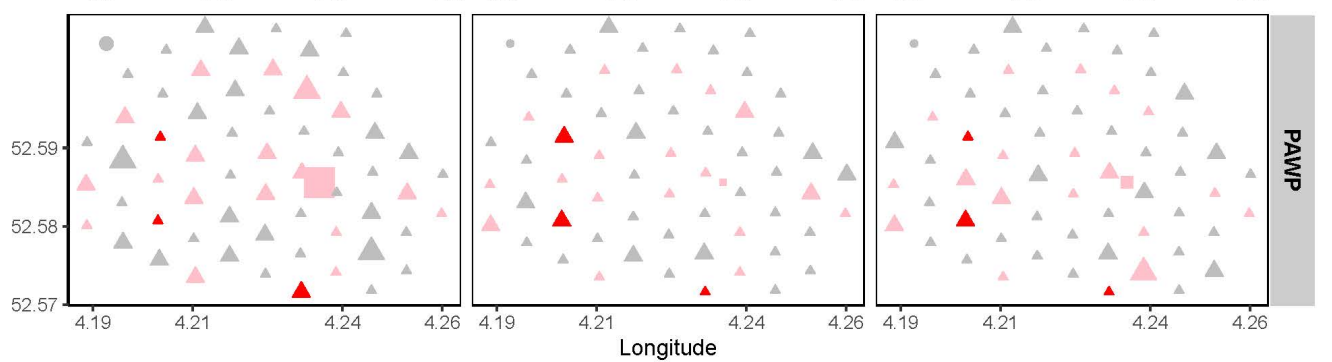

Aantal keer verstoord

- 0

- 1

- 2
- 4

Aantal vogels $\triangle \quad 0$

$\triangle \quad 1-2$

A 2-5

5-10

10-25

Figuur 16. Aantallen rustende (links) grote mantelmeeuwen op de verschillende molens (etc) in LUD, OWEZ en PAWP (van boven naar beneden) en de aantallen vliegende (midden) en zwemmende (rechts) vogels in deze parken, geplot op de dichtstbijzijnde molen, cumulatief over alle vijf surveys. De verschillende kleuren geven de mate van verstoring van de molens weer, in aantal malen verstoord (maximum vijf keer: verstoord bij alle vijf surveys).

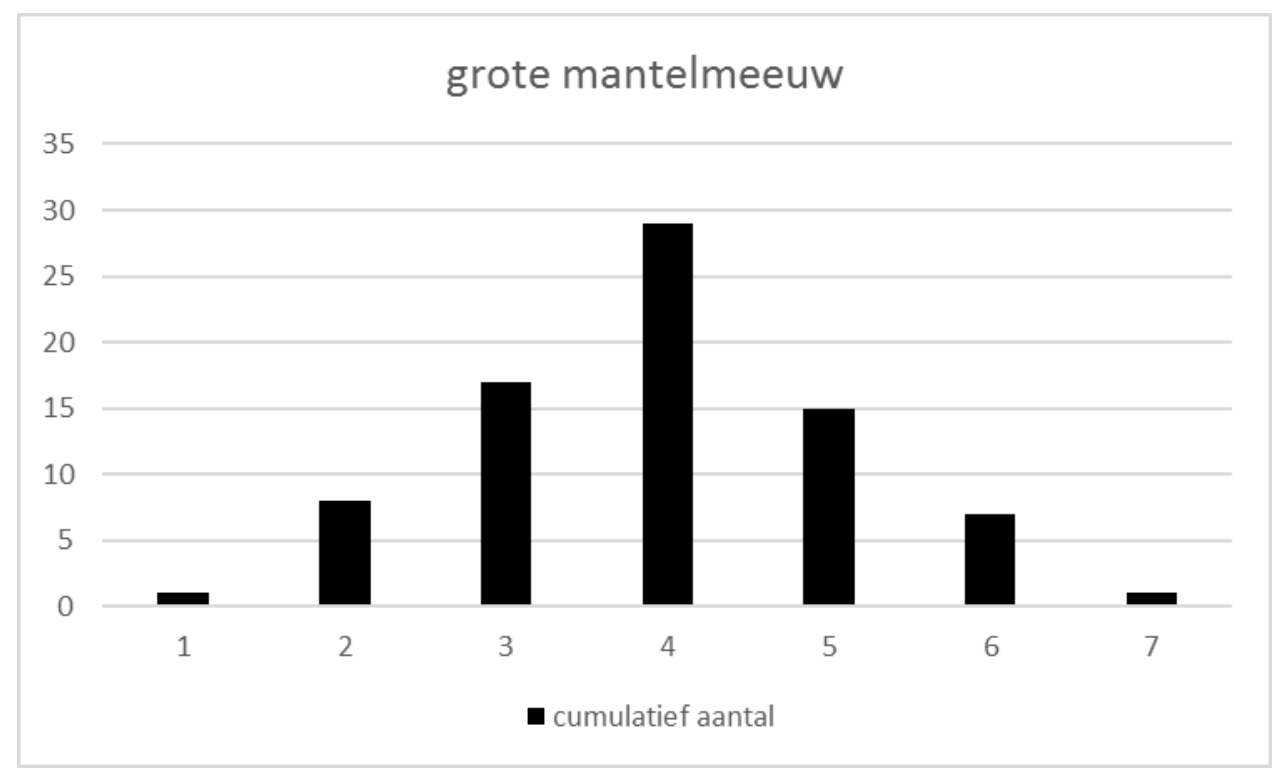

Figuur 17. De hoogtes boven het water (cumulatief over de vijf surveys) waarop grote mantelmeeuwen vliegend door de windparken werden gezien. Hoogteklassen 1-7: $1=0-2 \mathrm{~m} ; 2=2-10 \mathrm{~m} ; 3=10-25 \mathrm{~m} ; 4$ = 25-50m; $5=50-100 m ; 6=100-200 m ; 7=>200 m$ (geschat). 


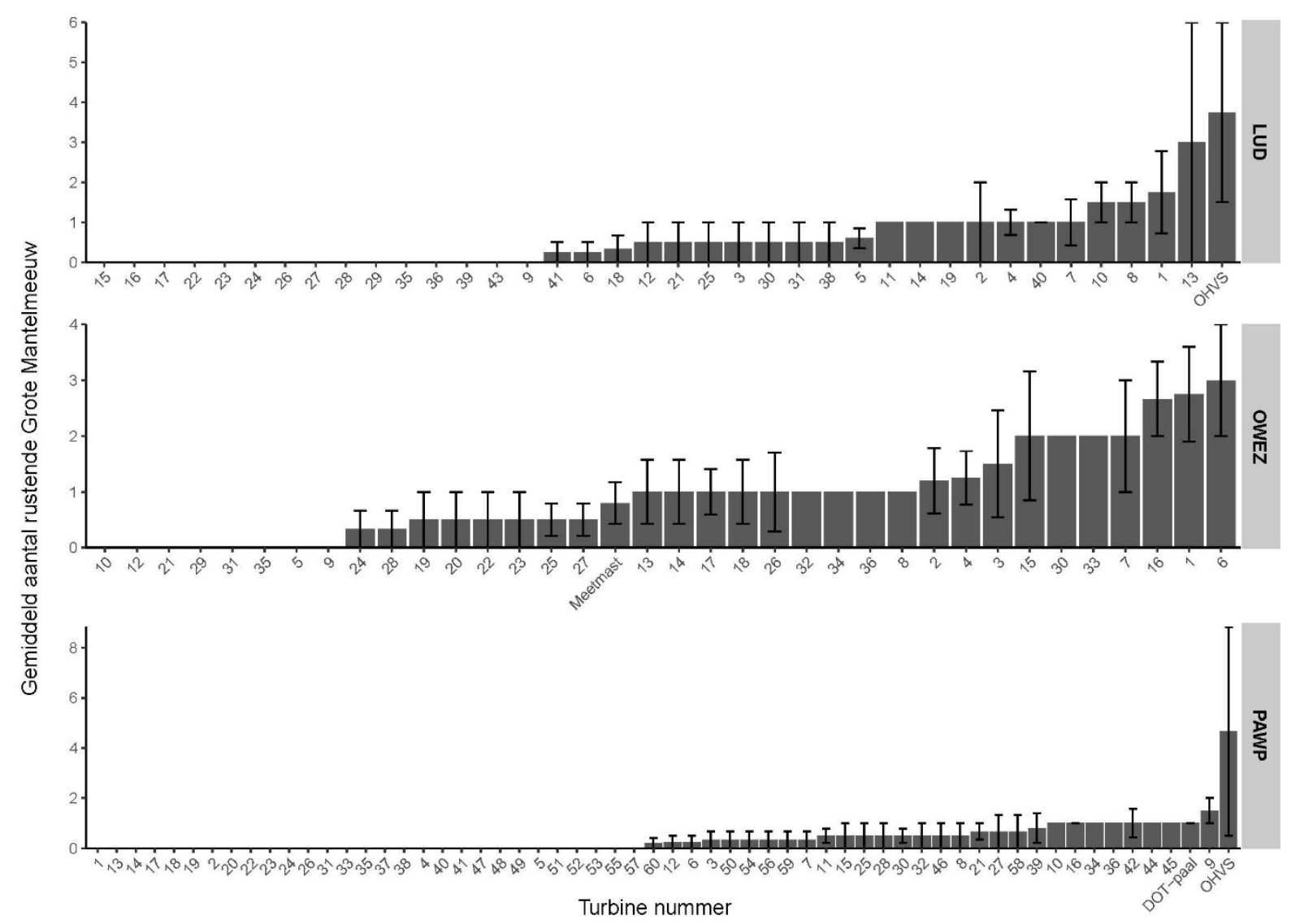

Figuur 18. Gemiddelde ( \pm standaarddeviaties) aantallen rustende grote mantelmeeuwen op de verschillende molens (etc) van de windparken LUD, OWEZ en PAWP, over de vijf surveys.

\subsubsection{Grote stern}

In de nabijheid van OWEZ, in natuurreservaat De Putten bij Camperduin (binnendijks) is recent een broedkolonie ontstaan van 2-3000 paren grote sterns. Dit was merkbaar tot in OWEZ: door dit park werden tijdens de juni-survey regelmatig vliegende grote sterns opgemerkt. Vogels die zeewaarts vlogen deden dit meestal zoekend (snavel omlaag gericht, niet in een vaste lijn vliegend); andere vogels waren duidelijk, in een strakke lijn laag over het water, en soms met een vis in de snavel, op weg naar de kolonie (in juni). In en zeewaarts van het park OWEZ werd dus door de grote sterns van De Putten ook gefoerageerd. Grote sterns werden alleen vliegend gezien. Voor 12 vogels werd als gedrag "zoekend" genoteerd: rondvliegend met de snavel omlaag gericht. Eén vogel dook daadwerkelijk het water in en twee vogels doken eveneens omlaag, maar braken de duik af voordat het water werd bereikt. Na juni waren de meeste grote sterns al weer verdwenen. In juni werd nog één grote stern opgemerkt (in LUD), in augustus vijf (OWEZ) en in september nog één (in OWEZ). Deze soort vertoonde geen enkele zichtbare reactie op ons schip of op andere schepen in het park, ook niet wanneer er vanaf ons schip werd gehengeld. De vogels vlogen tot net voorbij OWEZ de zee op, maar in het iets verderop gelegen PAWP en in het aanzienlijk zuidelijker, en nog verder van de kolonie gelegen LUD werd geen enkele grote stern gezien in juni.

Van alle waargenomen grote sterns vloog 39\% onder rotorhoogte, de meerderheid vloog dus op rotorhoogte (figuur 19). Vogels die tegen de wind in, naar de kolonie terug vlogen met een vis in de snavel vlogen meestal net boven het wateroppervlak; vogels die naar prooi aan het zoeken waren voor die met de wind in de rug vlogen, deden dit meest op hoogtes tussen 25 en 50 meter boven zee. 


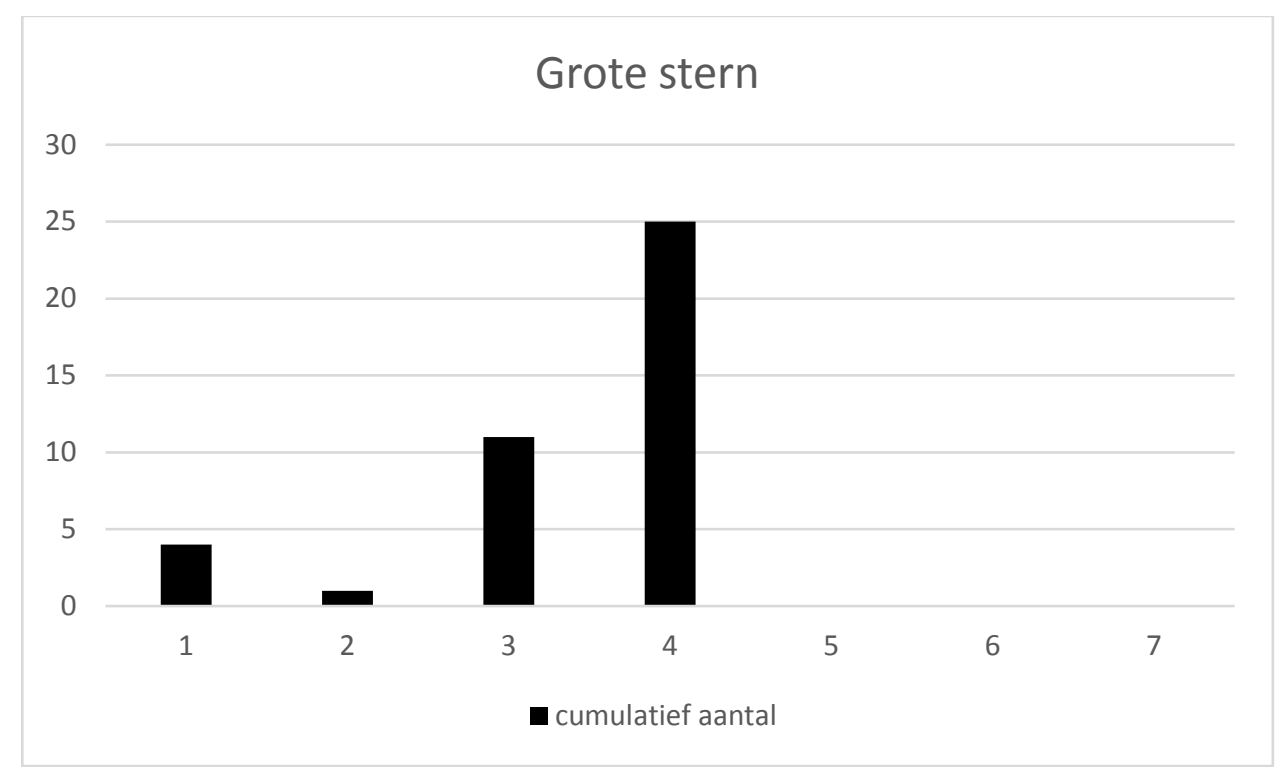

Figuur 19. De hoogtes boven het water (cumulatief over de vijf surveys) waarop grote sterns vliegend door de windparken werden gezien. Hoogteklassen 1-7: $1=0-2 m ; 2=2-10 m ; 3=10-25 m ; 4=25-$ 50m; $5=50-100 m ; 6=100-200 m ; 7=>200 m$ (geschat).

\subsubsection{Drieteenmeeuw}

Drieteenmeeuwen ontbraken geheel van juni tot en met augustus. In september werd een groepje van 15 drieteenmeeuwen zwemmend in LUD aangetroffen. In oktober werden er vier van dergelijke groepen zwemmende drieteenmeeuwen (15-40 vogels per groep) in OWEZ gezien en vier groepjes van twee tot drie vogels in LUD. In deze twee parken werden ook enkele (6 in totaal) vliegende drieteenmeeuwen gezien, op hoogtes 2-4 (tussen de 10 en 50 meter hoog).

Scheepvaart, inclusief hengelen trok geen enkele drieteenmeeuw aan.

\subsubsection{Andere kleinere meeuwen: kokmeeuw en stormmeeuw}

Kleine meeuwen ontbraken vrijwel geheel in juni: er werd slechts één stormmeeuw (vliegend) genoteerd. In juli werden twee stormmeeuwen (in OWEZ en in LUD), en een kokmeeuw (LUD) opgemerkt. Een van deze twee stormmeeuwen wist maar ternauwernood te ontkomen aan een aanvaring met de wieken van een van de molens in OWEZ: deze vogel vloog op rotorhoogte richting een windmolen en leek zich pas op het allerlaatste moment bewust van het gevaar en week toen alsnog, met een abrupte koerscorrectie, uit. Deze vogel vloog op een paar honderd meter afstand van het onderzoekschip langs en er waren geen andere schepen in de buurt. Er was geen reden om aan te nemen dat deze waargenomen bijna-botsing scheepvaart-gerelateerd was.

In augustus werden 11 kokmeeuwen genoteerd die door de diverse parken vlogen (hoogtes: 3-5) en in oktober vijf (op hoogte 3). In oktober werden ook enkele stormmeeuwen gezien: vier vliegend (hoogtes 2-4) en acht zwemmend.

Het hengelen trok geen enkele van deze kleine meeuwen aan. 


\subsubsection{Schaarsere soorten}

Alle overige soorten vogels die vliegend of zwemmend in de windparken werden gezien tijdens de vijf surveys waren schaarse passanten, of tijdelijk ter plaatse aanwezig. Tot deze laatste categorie rekenen we een slechtvalk, die in september en oktober werd gezien op en rond het OHVS van LUD. Slechtvalken verblijven wel vaker op offshore installaties, inclusief windmolenparken (eigen waarnemingen) en jagen van daaruit op passerende trekvogels. Zeekoeten waren schaars in de parken aanwezig vanaf augustus; een enkele alk werd zwemmend gezien in OWEZ in oktober. Ook de meeste zeekoeten werden zwemmend waargenomen; slechts één exemplaar werd vliegend gezien, net boven het zeeoppervlak (hoogte 1) in september in OWEZ en een groepje van drie zeekoeten vloog net binnen de rand van PAWP, langs de nieuw geplaatste DOT molen, in oktober, ook op hoogte 1.

Andere schaarse passanten waren een rotgans, drie jan-van-genten, een blauwe reiger, een kievit en in september en oktober was er enige zichtbare trek van zangvogels (graspiepers en spreeuwen).

Van geen van de vogels uit deze groep mag verwacht worden dat scheepvaart in de parken een meetbaar effect zal hebben op de aanvaringskansen.

\subsubsection{Zeezoogdieren}

Zowel in juni, juli, als in augustus werd een enkele bruinvis gezien, in juni in OWEZ en in juli en in augustus in LUD. In augustus werd ook een enkele gewone zeehond gezien, deze zwom vlak bij turbine \#10 in OWEZ en leek met deze fundatie geassocieerd. Grijze zeehonden werden gezien in juli (een, in LUD) en in augustus (twee of drie dieren; een dier werd wellicht op twee locaties gezien, in OWEZ). 


\section{Waargenomen hengelaars en andere recreanten in de parken}

Tijdens de juni survey troffen we twee bootjes met elk twee hengelaars in LUD, bij molens 39 en 40 (Figuur 20). Via AIS waren de bootjes niet te zien. Vermoedelijk omdat de wind aan het aantrekken was, en de bootjes wel erg klein waren in de opzettende golven, voeren ze kort nadat we ze hadden gezien weg, richting IJmuiden. In de tijd (circa een kwartier lang) dat we deze bootjes in beeld hadden, vertoonde geen enkele vogel een reactie op hun aanwezigheid. Tijdens de juli survey werden geen hengelaars gezien in de windparken.
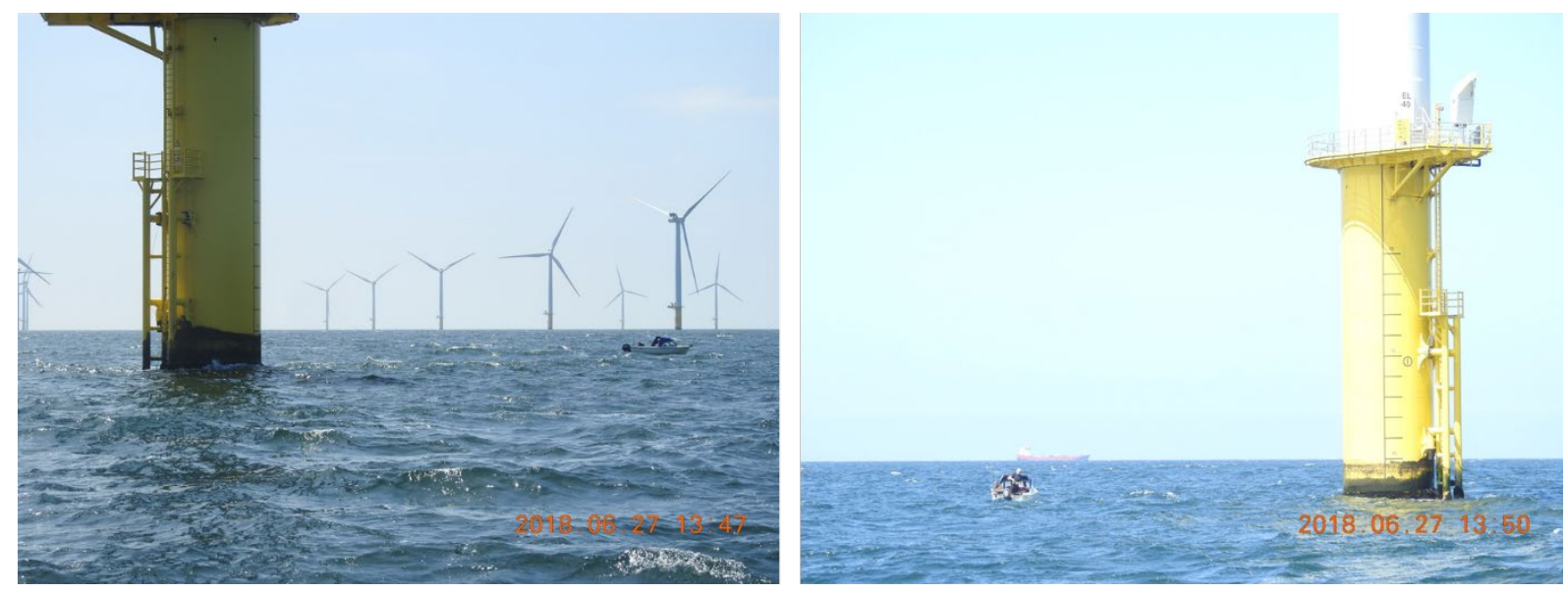

Figuur 20. Hengelaarsbootjes bij molens 39 (links) en 40 (rechts) in LUD, 27 juni 2018.

In augustus zagen we een grotere en een kleinere boot met hengelaars ruim buiten OWEZ, ter hoogte van molen \#2 aan de zuidwestkant van het park. Zolang we deze boten konden zien, maakten ze geen aanstalten het park binnen te gaan. Aan de rand van windpark LUD zagen we, eveneens tijdens de augustus-survey de middelgrote sportvisboot Wahoo varen. Er werd radiocontact opgenomen met de schipper: men kwam van verder op zee (bij een wrak) terug naar de haven varen en men maakte nog een korte tussenstop net binnen het windpark (op geruime afstand van molen \#3) in de hoop nog wat makreel te vangen. Dat lukte niet erg en men zette de reis na circa 10 minuten weer voort, richting IJmuiden.

Tijdens de september-survey zien we een snelle motorboot met vier opvarenden OWEZ binnen varen, net aan het einde van onze survey aldaar. Onze laatste activiteit in OWEZ was 15 minuten hengelen, meteen daarna gingen we richting PAWP en die koers bracht ons richting deze motorboot. De schipper leek op ons te reageren door voor ons weg te varen, ook richting PAWP dus we voeren een tijdje achter elkaar aan, maar de motorboot was sneller en raakte geleidelijk uit zicht. Voor zover zichtbaar had men geen hengels aan boord; het leek te gaan om een toertocht.

Alle andere waargenomen scheepvaart tijdens onze vijf surveys had te maken met onderhoud in de windmolenparken, of bevond zich buiten de parken. 


\section{AIS gegevens scheepvaart}

Onderzoeksinstituut MARIN (Maritiem Research Instituut Nederland) in Wageningen heeft de AISgegevens (Automatic Identification System) onderzocht van de scheepvaart in en rond de drie windparken voor de Hollandse kust. Een samenvattende analyse per maand (juni-oktober 2018) is via Rijkswaterstaat voor het onderzoek naar de effecten van doorvaart op vogels beschikbaar gemaakt voor deze rapportage. MARIN heeft gewerkt met de door de Kustwacht aangeleverde data. Deze betreffen alleen de gegevens, bekend vanuit de AIS-data (transpondergegevens van schepen in het werkgebied). NB: alle scheepvaart, inclusief recreatievaart, is verplicht een AIS signaal uit te zenden. Dit signaal is zichtbaar voor de kustwacht en voor andere scheepvaart. Ons is echter gebleken dat sommige kleine bootjes met hengelaars binnen de parken geen AIS signaal uitzonden (figuur 20). De data zijn dus niet volledig, want sommige scheepjes blijven "onder de radar", dat wil zeggen: zenden geen AIS signaal uit, maar zijn mogelijk nog wel zichtbaar voor de kustwacht radar aan de wal.

De ontvangen AIS signalen zijn per maand samengenomen en uitgesplitst naar verschillende categorieën van scheepvaart en er is onderscheid gemaakt tussen dag en nacht en weersomstandigheden met "weinig" wind (minder dan 4 Bft), matige wind (4-7 Bft) en met veel wind (meer dan $7 \mathrm{Bft}$ ). Daarnaast zijn de gegevens gegroepeerd voor schepen van verschillende nationaliteit, lengte ( $<24 \mathrm{~m} ; 24-45 \mathrm{~m} ; 45 \mathrm{~m}$ en langer) en eigenschappen die te maken hebben met de werkzaamheden cq activiteiten van het schip (Tabel 3). De lijst is voor een breder gebruik dan voor de analyse van scheepvaart in en rond de windparken. Zo komen hovercrafts hier niet voor, maar schepen die door een hydrofoil (waterjet) worden aangedreven wel: hieronder vallen vermoedelijk de nodige windcat die voor onderhoud worden ingezet (en die dan wellicht beter onder Maintenance hadden kunnen vallen). Grote schepen als grote vrachtschepen, ferry's en tankers mogen niet in de parken komen maar kunnen wel op enige afstand langs varen en dus voor deze rapportage worden geregistreerd. Op bijgeleverde kaartbeelden is dan te zien welke scheepvaart zich buiten de parken beweegt en dus niet relevant is voor de effecten van doorvaart op vogels. Voor dit rapport zijn vooral gegevens van recreatievaart (Recreation), visserij (Fishing) en onderhoud (Maintenance) van belang. Alle scheepvaart is bovendien beoordeeld op de verblijfstijd in de parken en op "stil liggen": meer dan 1 uur stil liggen (snelheid lager dan 1 knoop).

Tabel 3. Overzicht van de verschillende scheeptypen/activiteiten, onderscheiden voor de analyses van AIS gegevens. De Engelstalige benamingen zoals gebruikt door MARIN zijn hier aangehouden.

\begin{tabular}{|l|l|}
\hline Scheepstype & Omschrijving MARIN \\
\hline Recreation & Pleasure craft, sailing e.g. \\
\hline Fishing & Fishing vessel, Trawler, Fish Carrier e.g. \\
\hline GDC (General Dry Cargo) & Cargo barge, Bulker, Pipe carrier e.g. \\
\hline HSC (High Speed Craft) & Hydrofoil, hovercraft \\
\hline Operations & Towing, dredging, diving, military e.g. \\
\hline Passenger & Passengers ship, Inland ferry, Ro-Ro, e.g. \\
\hline Port & Pilot vessel, SAR, tugs, port tender, medical e.g. \\
\hline Tanker & Chemical tanker, Bunkering tanker, Lpg e.g. \\
\hline WIG (Wing In Ground) & Flarecraft, sea skimmer, ekranoplans e.g. \\
\hline Other & Other \\
\hline Undefined & Reserved for future use \\
\hline Maintenance & Workships authorised by Windfarm owner \\
\hline
\end{tabular}

In de regel werden vooral schepen $<24 \mathrm{~m}$ en schepen met lengtes tussen 24 en $45 \mathrm{~m}$ geregistreerd binnen de grenzen van de windparken, in de categorieën HSC, Maintenance, Recreation en Undefined. Ons eigen schip is ook geregistreerd en zal vermoedelijk onder Undefined vallen. Vissersschepen werden ook met regelmaat geregistreerd, evenals een enkel surveyschip (inclusief ons eigen schip), te herkennen aan regelmatige vaarlijnen. Sommige vissersschepen schampten de periferie van de parken (kwamen net binnen de veiligheidszone van 500 meter en werden zodoende in de registratie meegenomen. Vooral in de zomermaanden waren tracks van zeilboten te zien (herkenbaar aan 
zigzaggen: overstag gaan). Op de bijgeleverde kaartbeelden en tabellen is te zien dat het vooral gaat om onderhoudsschepen, te herkennen aan heen en weer varen tussen de haven van IJmuiden en de windparken; deze schepen hebben ook een aanzienlijke verblijfstijd in de parken (want ze zijn ingezet voor onderhoud aan turbines en OHVS installaties).

De hoeveelheid "extra" scheepvaart (d.w.z. scheepvaart waarvan de aanwezigheid in de windparken gekoppeld is aan de beleidswijziging) was in feite erg klein, al zijn enkele recreatie-tracks wel te vinden tussen alle tracks van de onderhoudsschepen. De aangeleverde beelden stemmen goed overeen met wat wij zelf in het veld zagen tijdens de vijf surveys: er waren altijd en in alle parken onderhoudsschepen aan het werk; buiten de parken voeren en lagen allerlei andere schepen, inclusief hele grote, maar scheepvaart anders dan voor onderhoud in de parken was uitermate schaars.

Bootjes met hengelaars vallen onder "Recreation", maar in deze categorie valt ook alle andere recreatievaart zoals zeilboten en motorboten zonder hengelaars. Alle vaart die onder recreatie valt, is echter vaart die voor de openstelling van de windparken niet binnen de parken mocht komen en hun aanwezigheid is dus een gevolg van de beleidswijziging. In ieder geval een deel van de recreatievaart bestond uit hengelaars. OWEZ had de meeste registraties, gevolgd door LUD en PAWP. Gemiddeld iets meer dan $10 \%$ van alle recreatievaart werd 's nachts geregistreerd (Tabel 4) en de zaterdag was de meest populaire dag van de week voor de recreatievaarders (Tabel 5)

Tabel 4. Aantallen geregistreerde recreatievaartuigen in de drie windparken per maand. Tussen haakjes zijn de aantallen uitgesplitst naar registraties overdag/'s nachts.

\begin{tabular}{|c|c|c|c|c|}
\hline Maand & OWEZ & PAWP & LUd & Totaal \\
\hline Juni & $16(14 / 2)$ & $5(4 / 1)$ & $6(4 / 2)$ & $\mathbf{2 7}(\mathbf{2 2} / 5)$ \\
\hline Juli & $22(17 / 5)$ & $4(4 / 0)$ & $9(9 / 0)$ & $\mathbf{3 5}(\mathbf{3 0} / 5)$ \\
\hline Augustus & $26(25 / 1)$ & $14(14 / 0)$ & $22(19 / 3)$ & $\mathbf{6 2 ( 5 8 / 4 )}$ \\
\hline September & $9(8 / 1)$ & $6(3 / 3)$ & $7(6 / 1)$ & $\mathbf{2 2 ( 1 7 / 5 )}$ \\
\hline Oktober & $5(5 / 0)$ & $5(5 / 0)$ & $5(3 / 2)$ & $\mathbf{1 5 ( 1 3 / 2 )}$ \\
\hline Totaal & $\mathbf{7 8 ( 6 9 / 9 )}$ & $\mathbf{3 4 ( 3 0 / 4 )}$ & $\mathbf{4 9 ( 4 1 / 8 )}$ & $\mathbf{1 6 1 ( 1 4 0 / 2 1 )}$ \\
\hline
\end{tabular}

Tabel 5. Aantallen geregistreerde recreatievaartuigen per dag van de week. Alle registraties zijn opgeteld voor de drie parken en voor dag en nacht.

\begin{tabular}{|c|c|c|c|c|c|c|}
\hline ma & di & wo & do & vr & za & zo \\
\hline 13 & 23 & 24 & 13 & 27 & 40 & 19 \\
\hline
\end{tabular}

Een groot probleem bij de interpretatie van de MARIN rapportages is, dat deze gegroepeerd zijn per maand en dat er op slechts enkele uren per maand vanaf Het Sop in ieder park directe visuele waarnemingen zijn gedaan. Tijdens geen enkele van die visuele waarnemingen is een zeilschip waargenomen, of een visserschip dat een park "schampte". Dit maakt het onmogelijk om eventuele effecten van deze door MARIN wel waargenomen schepen op vogelgedrag in de parken direct in te schatten. Wel zijn enkele bootjes met hengelaars en een recreatie (speed)boot waargenomen, maar die bootjes trokken geen enkel vogel aan, zolang ze vanaf Het Sop zichtbaar waren. Effecten van de beleidswijziging die doorvaart mogelijk maakt, dat wil zeggen, van de "extra" scheepvaart, naast het reguliere onderhoud met schepen in de parken op de zeevogels ter plaatse, kunnen dus alleen worden ingeschat op basis van de reacties van de vogels op Het Sop en op basis van meer algemene ervaringen.

Vanaf het Sop waren twee effecten van zeevogels zichtbaar. Iedere keer, als het schip (voor de vogels) te dicht bij een turbine kwam waarop aalscholvers rustten, vlogen deze allemaal van de turbine af, waarbij de kritische afstand rond de 100 meter leek te liggen. "Op"vliegende aalscholvers waren hierbij in feite altijd neerwaarts vliegende aalscholvers: ze lieten zich vanaf hun rustplaats vallen om voldoende snelheid te kunnen maken om in de lucht te blijven. Omdat alle rustplaatsen op turbine fundaties zich onder rotorhoogte bevonden, was de aanvankelijke uitvliegroute altijd onder rotorhoogte, dus zonder gevaar op een botsing met de wieken. De meeste van deze opgevlogen aalscholvers vlogen vervolgens naar een alternatieve rustplaats, op een andere turbinefundatie. Dit is "normaal" vliegverkeer voor de 
aalscholvers in de parken en de vogels leken volkomen vertrouwd met de situatie ter plaatste: nooit zagen we een aalscholver in een gevaarlijke positie ten opzichte van ronddraaiende wieken. Aalscholvers op de OWEZ meetmast en op de OHVS installaties in PAWP en LUD bevonden zich merendeels wel op rotorhoogte, maar omdat Het Sop zich volgens de voorschriften nooit dicht bij deze installaties kwam, werden deze vogels nooit opgeschrikt.

De effecten van de overige waargenomen schepen (alle: onderhoudsschepen) waren gelijk aan die van het Sop. Bij nadering van een turbine vlogen eerst alle aalscholvers weg en vervolgens de meeuwen. In geen enkel geval zagen we een aanwijzing voor een mogelijke (bijna)botsing als gevolg van een dergelijke nadering.

Voor de meeuwen lag de situatie iets anders. Deze lieten zich minder snel verjagen dan aalscholvers (zie bijvoorbeeld figuur 13), maar konden sneller hoogte winnen dan de aalscholvers wanneer ze zich toch van een turbine lieten verjagen. Meeuwen vlogen in het algemeen ook vaak hoger dan aalscholvers, vaker op rotorhoogte en soms zelfs daar boven. We hebben een bijna botsing waargenomen (van een stormmeeuw) en (de gevolgen van) een echte botsing: we troffen een zwaar gewonde volwassen grote mantelmeeuw aan in PAWP. Die vogel werd met een schepnet uit het water gevist, en bleek bij inspectie een klap op het lichaam gehad. De vogel was groggy, maar had aan het lichaam geen zichtbare verwondingen en ook geen gebroken vleugels. De rechterpoot bloedde echter hevig en de rechtervoet hing nog aan slechts één pees. De botsing zelf hebben we niet waargenomen maar er waren verder geen schepen in de buurt en deze botsing leek, evenals de waargenomen bijna-botsing, niet gerelateerd aan scheepvaart.

Een tweede effect van varen met Het Sop door windparken was, dat een enkele meeuw soms even kort achter het schip kwam kijken (meevliegen). Dit gedrag duurde nooit langer dan enkele seconden: het schip produceerde niets eetbaars (maar ziet er uit als een schip met hengelaars). Ook tijdens onze hengelsessies waren er niet of nauwelijks reacties van vogels waarneembaar. Hierbij zij aangetekend, dat we geen visafval (ingewanden van schoongemaakte vis en dergelijke) overboord zetten. Ook de waargenomen hengelaars in de parken zagen we dit niet doen, maar we weten dat dit wel gemeengoed is onder hengelaars op zee. Verwacht mag dus worden, dat hengelaars die in een windpark hun vangst schoonmaken en het afval overboord zetten, wel degelijk meeuwen zullen aantrekken. Er is voldoende aanbod van meeuwen in de parken: er vliegen vogels rond en er zitten vogels op de turbinefundaties rond te kijken. 


\section{Discussie}

Deze studie is vooral een verkenning, geen gedetailleerd en gevalideerd wetenschappelijk onderzoek. Tussen de laatste wintersurvey (januari) en de start van de serie zomer/herfstsurveys (juni) zit een "gat" van vier maanden. De overgang van de wintersituatie naar de zomersituatie lijkt daardoor wellicht abrupter dan deze in werkelijk was. Toch lijken de uitkomsten van de vijf zomersurveys in grote lijnen op die uit de wintersituatie. De aalscholver was nog steeds de dominante soort, al waren de zomeraantallen duidelijk hoger dan die in de winter. Echte wintergasten, zoals futen, alkachtigen en drieteenmeeuwen waren in de zomer afwezig (drieteenmeeuwen en zeekoeten kwamen in de late zomer/vroege herfst wel binnen) en hetzelfde geldt voor de jan-van-gent, die toch een minder uitgesproken wintergast is in Nederlandse wateren. Een opvallende zomerse aanwezige was de grote stern, maar deze werd alleen in juni in noemenswaardige aantallen gezien en dan nog alleen in het windpark dat het dichtst bij de enige Noord-Hollandse vasteland kolonie (De Putten) ligt: OWEZ. Hoewel deze kolonie nog volop actief was ten tijde van onze juli survey (eigen waarnemingen) waren er tijdens onze juli survey geen vogels meer zo ver op zee te zien dat hun foerageertochten overlapten met de windmolenparken. Ook blijft ongewis of grote sterns in en rond de windparken voorkomen in de vroege maanden van het vaarseizoen (april en mei). Vanaf ongeveer half maart zijn de vogels in ons land, maar in de maanden februari tot en met mei zijn in het kader van dit project geen waarnemingen op zee gedaan.

Ook in de zomermaanden juni en juli maakten verschillende soorten zeevogels gebruik van de parken. $\mathrm{Na}$ aalscholvers waren enkele soorten grote meeuwen: kleine mantelmeeuwen, zilvermeeuwen en (alleen in juli) grote mantelmeeuwen het talrijkst aanwezig. Deze grote meeuwen maakten ook relatief veelvuldig gebruik van de turbine fundaties als uitkijk en/of rustplaatsen. Van deze soorten mag daarom worden verwacht dat ze snel zullen kunnen inspelen op nieuwe mogelijkheden in hun omgeving, maar onze surveys hebben nog geen waarnemingen opgeleverd die erop duiden dat hengelaars in de parken dergelijke nieuwe mogelijkheden zouden kunnen bieden. Van de zeer talrijke aalscholvers valt eigenlijk niet te verwachten dat ze sterk zullen reageren op de aanwezigheid van hengelaars in een park, al is dat gezien het feit dat ze wel kotters volgen (Camphuysen 1999), nog niet helemaal uit te sluiten. Voor de meeuwen ligt het wellicht meer voor de hand dat ze op hengelaars in de parken zullen reageren. Vooralsnog waren de aantallen van zowel hengelaars als meeuwen in parken laag, en werden niet of nauwelijks zichtbare reacties van de meeuwen op de hengelaars vastgesteld.

Andere soorten dan aalscholver en grote meeuwen werden niet of nauwelijks in de windparken aangetroffen in juni en juli, met de grote stern en de drieteenmeeuw als enige uitzonderingen. Grote sterns zijn in Nederland echter voedselspecialisten die voornamelijk (>95\% van hun prooien, Veen 1977; Stienen et al. 2000) leven van zelf gevangen haring, sprot en zandspiering. Het zijn dus geen discardseters en van deze soort mag niet worden verwacht dat ze bootjes met hengelaars zullen opzoeken. Ook de waargenomen drieteenmeeuwen toonden geen enkele interesse in de aanwezige scheepvaart.

De aantallen hengelaars bleven vooralsnog beperkt, tot drie direct waargenomen bootjes. Ook de MARIN analyses van AIS gegevens laten geen grote aantallen bootjes zien in de parken (maar sommige bleven ongeregistreerd). Grotere (charter) schepen, met grotere aantallen hengelaars aan boord, werden tijdens deze twee surveys in de zomer van 2018, niet opgemerkt. Of dat in de nabije toekomst verandert, zal wellicht blijken tijdens de nog uit te voeren surveys. Gezien de geringe belangstelling van hengelaars voor de windparken en de geringe belangstelling van zeevogels voor de hengelaars, mogen we vooralsnog concluderen dat doorvaart weinig problemen oplevert voor zeevogels in de parken. Het meest kritisch in deze zal echter het gedrag van hengelaars in de parken zijn. Zodra er visafval overboord gaat, zal zich een wolk meeuwen rond het betreffende schip vormen. Of een dergelijke situatie vervolgens leidt tot (bijna)botsingen, valt met de huidige onderzoeksopzet niet of nauwelijks waar te nemen. Dergelijke situaties laten zich beter bestuderen door experimenten uit te voeren: zelf vissen en dan ook de gevangen vissen schoon maken aan boord) of door mee te varen commerciële hengeltochten, mochten deze worden aangeboden. 


\section{Dankwoord}

Dit project had niet kunnen worden uitgevoerd zonder de welwillende medewerking van de twee bedrijven die de windparken in eigendom hebben, Vattenfall, voor deze: NoordzeeWind (OWEZ) en Eneco (PAWP en LUD). Onze contacten verliepen steeds via: Bertram van Zanten (NoordzeeWind Offshore Windfarm Egmond aan Zee); en Bart van der Wielen en Sytske van den Akker (Eneco). Het benodigde contact met de Nederlandse Kustwacht liep via Jaap van den Hoed. Wij danken hen allen voor de prettige manier van samenwerken ten behoeve van dit project. Ook danken wij schipper Rutgert Oosterhuis en zijn mede-opvarende Simon de Smidt voor alle hulp bij de surveys, en onze medewaarnemers Nicole Janinhoff, Threes Schreurs en Fiet van Beek. 


\section{Literatuur}

Camphuysen C.J. 1999. New feeding technique of Great Cormorants Phalacrocorax carbo sinensis at beam trawlers. Atlantic Seabirds 1: 85-90.

Fujii T. 2016. Potential influence of offshore oil and gas platforms on the feeding ecology of fish assemblages in the North Sea. Marine Ecology Progress Series 542: 167-186.

Geelhoed S., van Bemmelen R., Keijl G., Leopold M. \& Verdaat H. 2011. Nieuwe kolonie Drieteenmeeuwen Rissa tridactyla in de zuidelijke Noordzee. Sula 24: 27-30.

Gyimesi A. 2018. Vogelradar in offshore windpark Luchterduinen. https://www.buwa.nl/effect-windparkluchterduinen.html

Leonhard S. \& Pedersen J. 2006. Benthic communities at Horns Rev before, during and after construction of Horns Rev Offshore Wind Farm. Vattenfall Final Report/Annual report 2005, 134p.

Leopold M.F. 2017. Seabirds? What seabirds? An exploratory study into the origin of seabirds visiting the SE North Sea and their survival bottlenecks. Wageningen Marine Research report C046/17.

Leopold M. \& Verdaat H. 2018. Reacties zeevogels in windparken bij doorvaart. Wageningen University \& Research rapport C024/18.

Platteeuw M., van der Ham N.F. \& den Ouden J.E. 1994. Zeetrektellingen in Nederland in de jaren tachtig. Sula $8(1 / 2$, special issue): 1-203.

Soldal A.V., Svellingen I., Jørgensen T. \& Løkkeborg S. 2002. Rigs-to-reefs in the North Sea: hydroacoustic quantification of fish in the vicinity of a "semi-cold" platform. ICES Journal of Marine Science 59: S281-S287.

Stienen E.W., Van Beers P.W., Brenninkmeijer A., Habraken J.M.P.M., Raaijmakers M.H.J.E., \& Van Tienen P.G. 2000. Reflections of a specialist: patterns in food provisioning and foraging conditions in Sandwich terns Sterna sandvicensis. Ardea 88: 33-49.

Veen J. 1977. Functional and causal aspects of nest distribution in colonies of the Sandwich tern (Sterna s. sandvicensis Lath.). Brill, Leiden.

Winter H.V., Aarts G. \& Van Keeken O.A. 2010. Residence time and behaviour of sole and cod in the offshore wind farm Egmond aan Zee (OWEZ). IMARES, Wageningen UR Report C038/10, 50p. 


\section{Verantwoording}

Rapport C066/18a

Projectnummer: 4312100090

Dit rapport is met grote zorgvuldigheid tot stand gekomen. De wetenschappelijke kwaliteit is intern getoetst door een collega-onderzoeker en het directielid van Wageningen Marine Research.

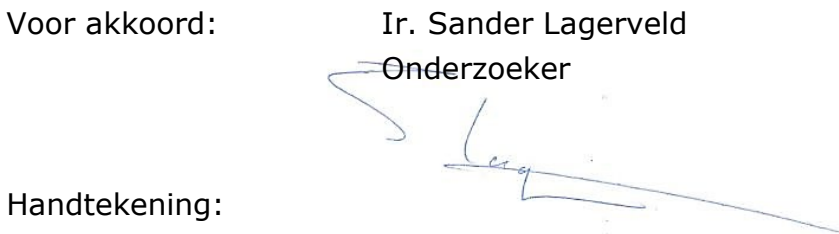

Datum:

27-11-2018

Voor akkoord:

Jakob Asjes

Manager Integratie

Handtekening :

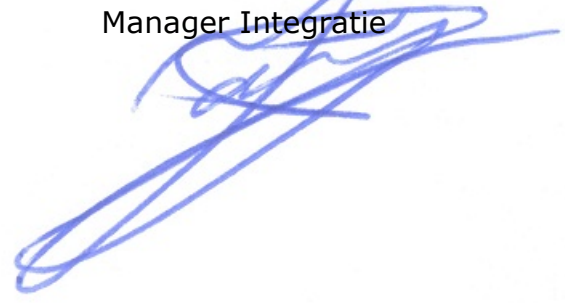

Datum:

$30-11-2018$ 
Bijlage: Verspreidingskaarten per soort, per survey, per windpark 


\section{Survey 1: Aalscholver in windmolenpark OWEZ}

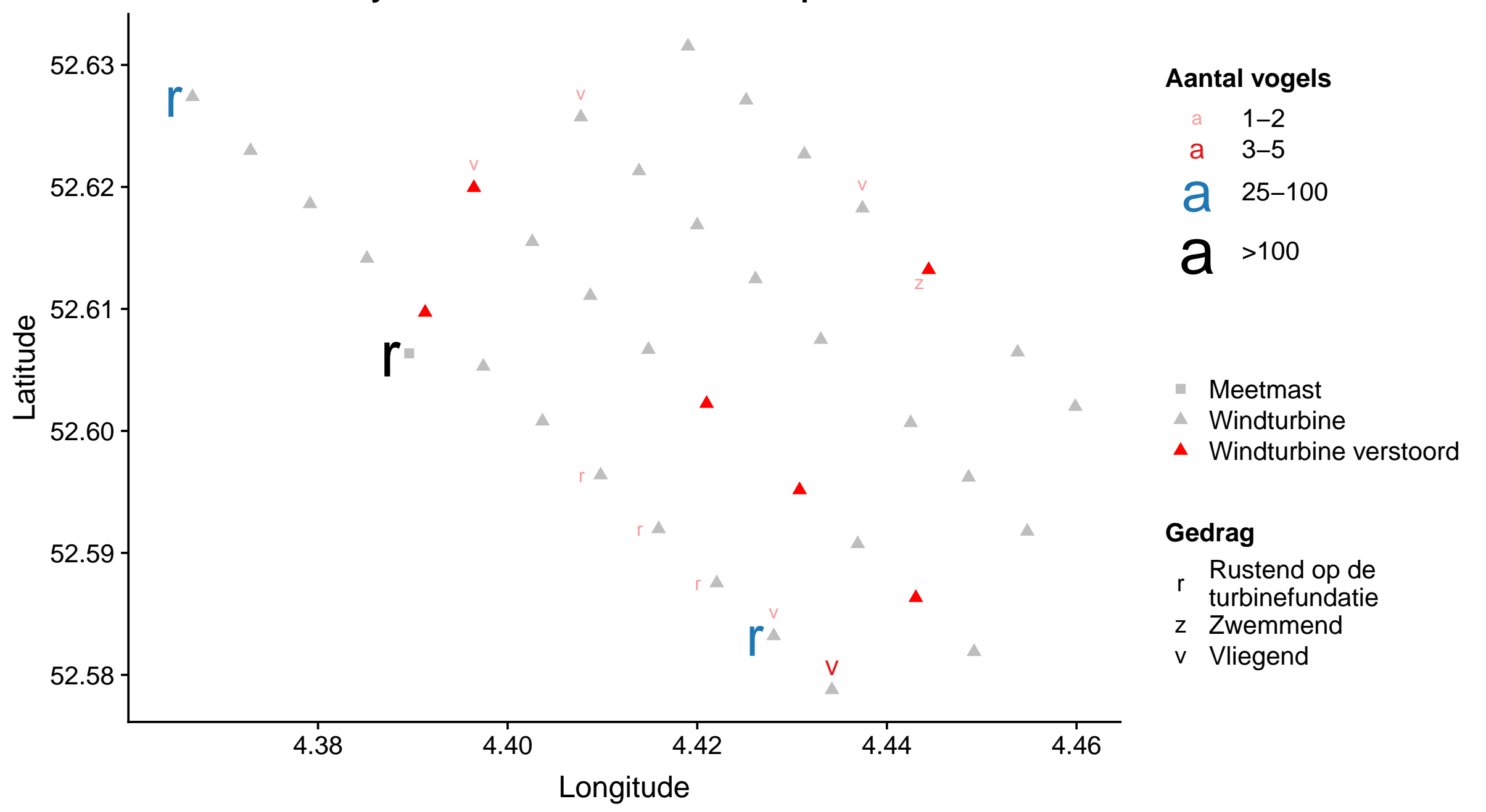




\section{Survey 1: Aalscholver in windmolenpark PAWP}

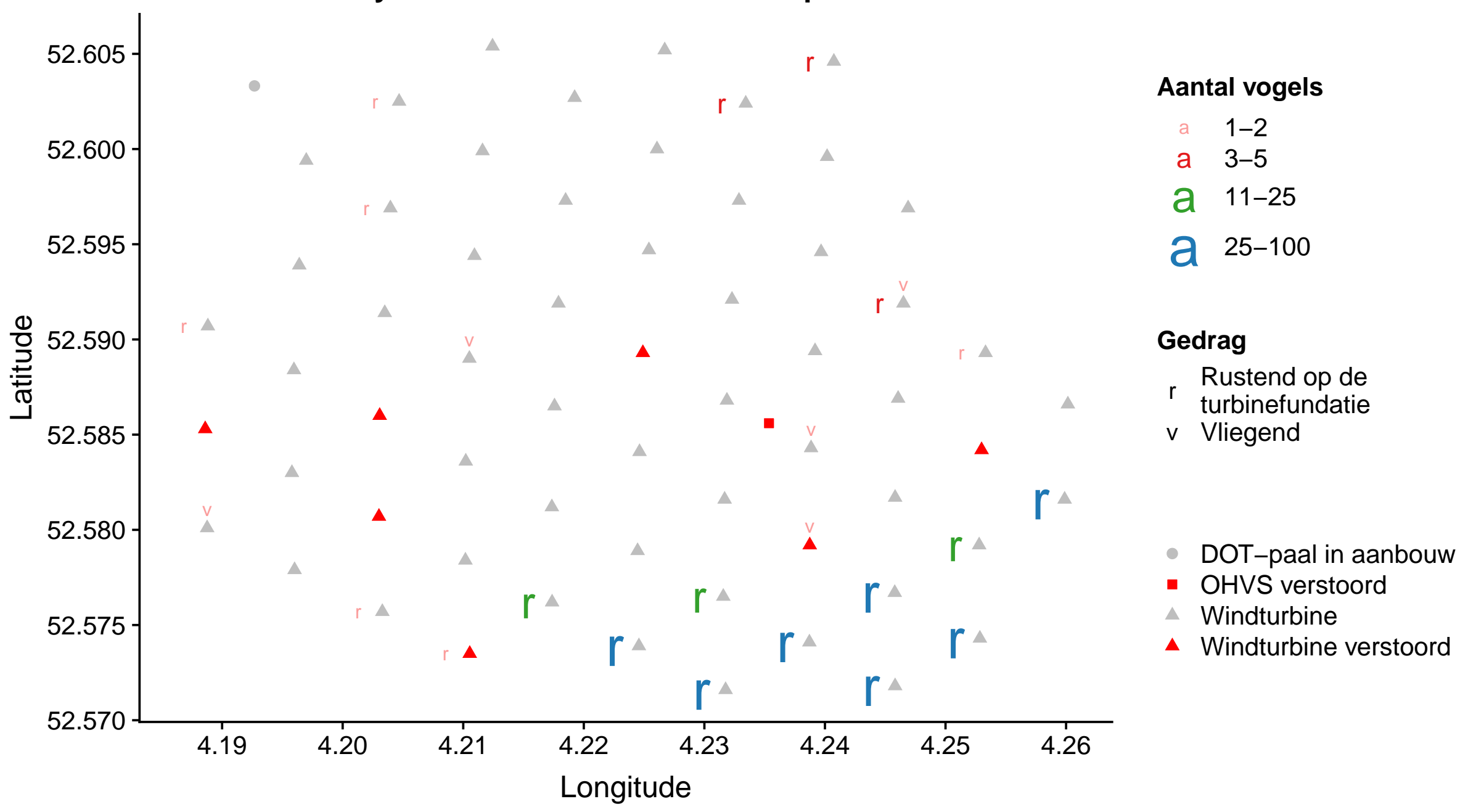


Survey 1: Aalscholver in windmolenpark LUD

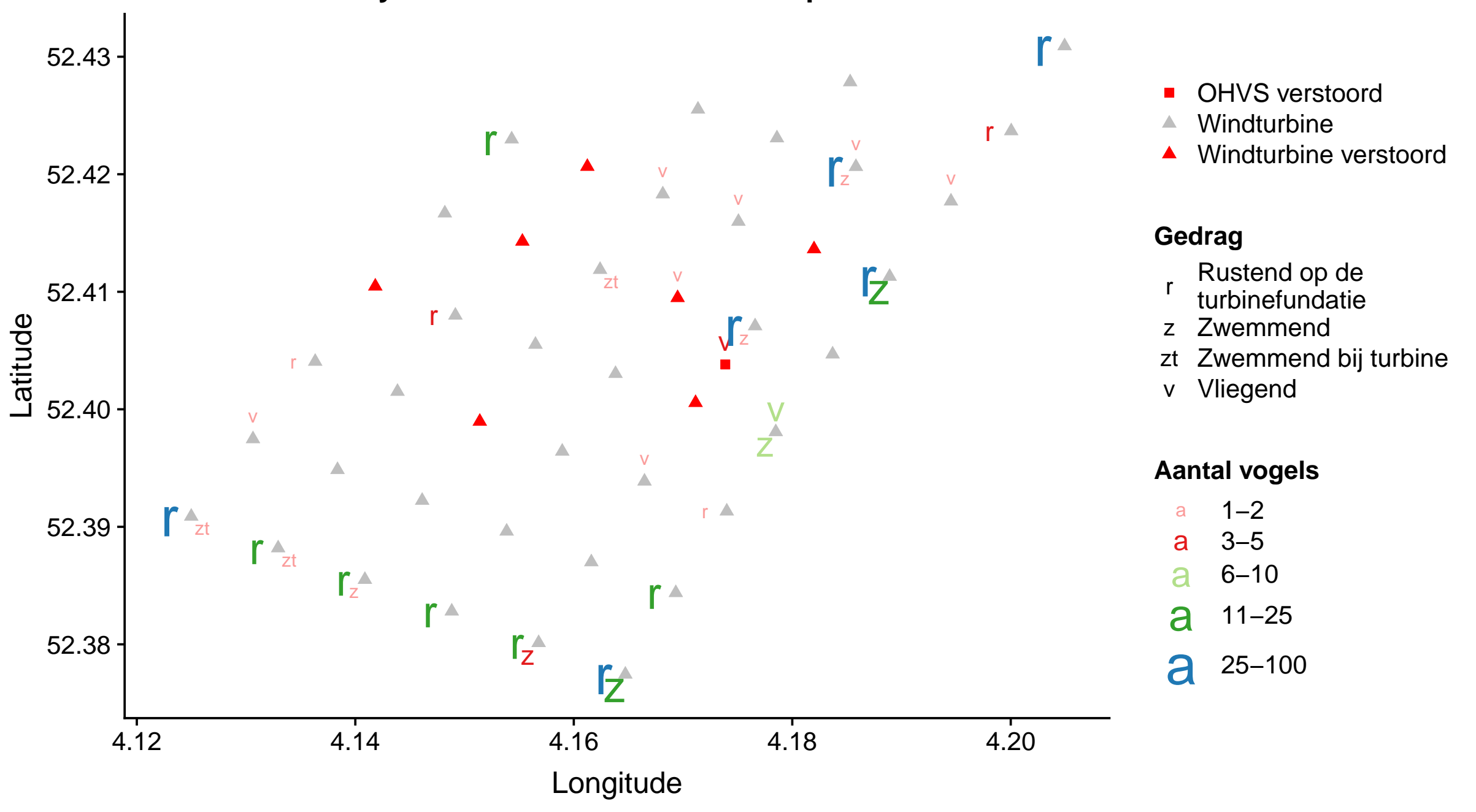




\section{Survey 2: Aalscholver in windmolenpark OWEZ}

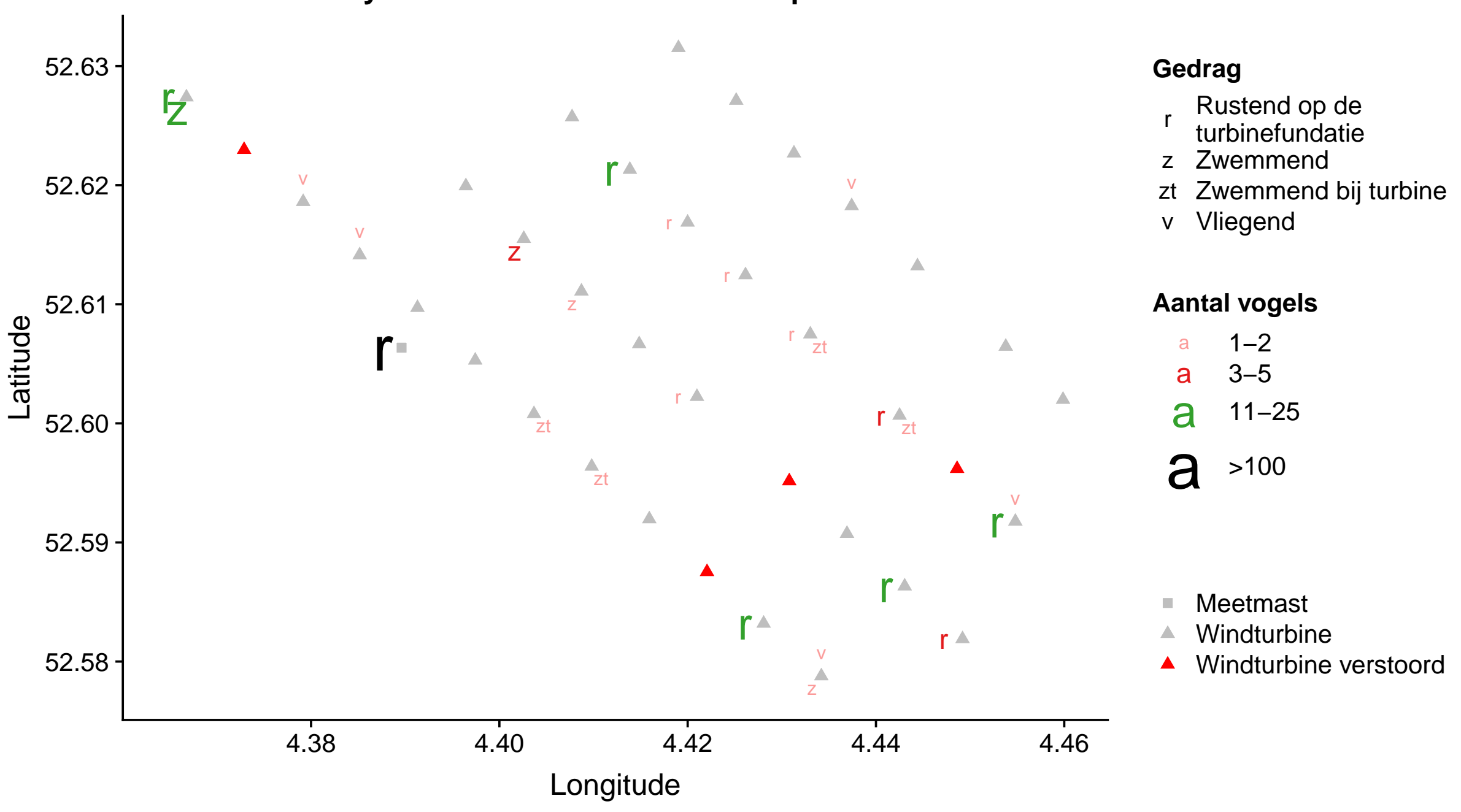




\section{Survey 2: Aalscholver in windmolenpark PAWP}

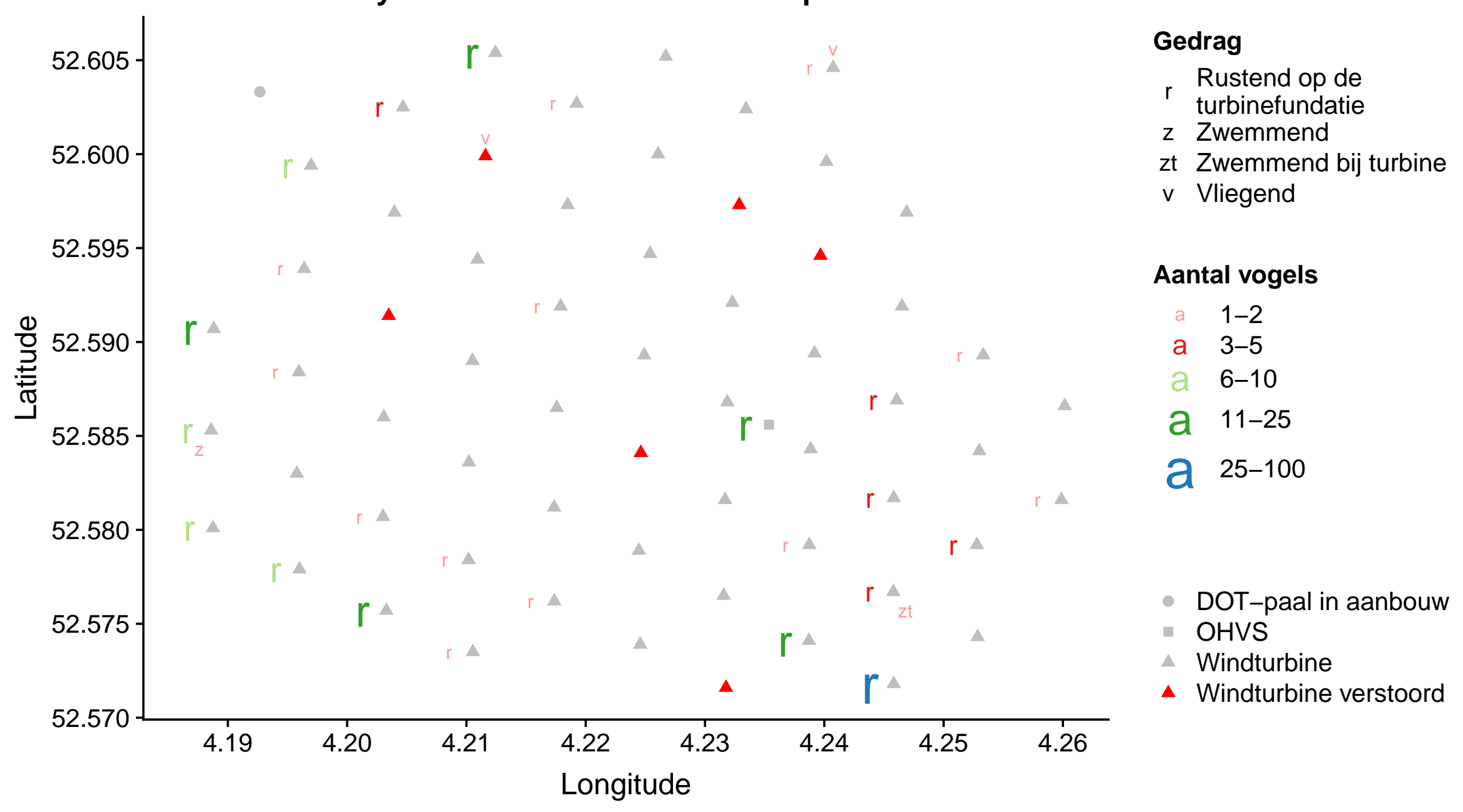




\section{Survey 2: Aalscholver in windmolenpark LUD}

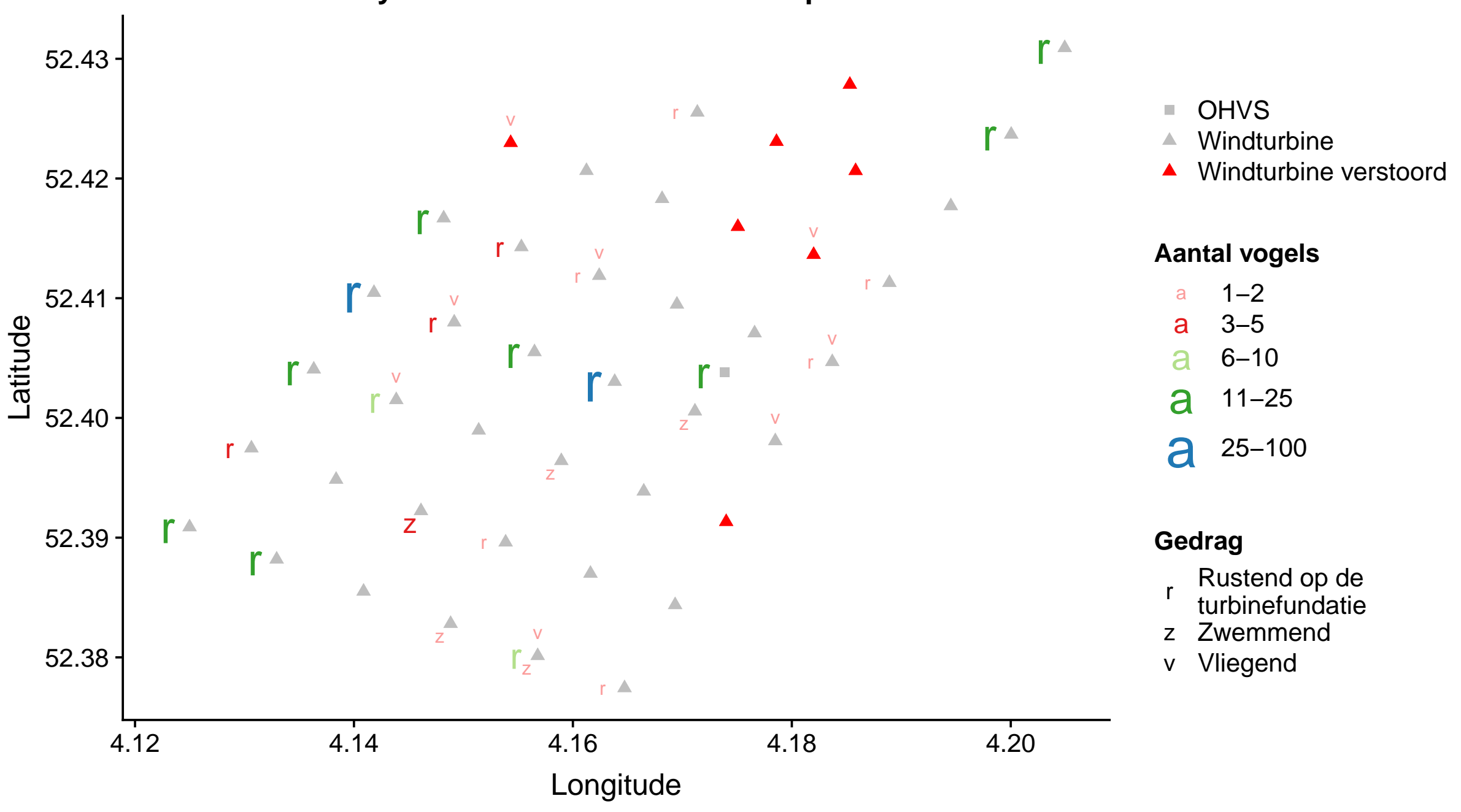


Survey 3: Aalscholver in windmolenpark OWEZ

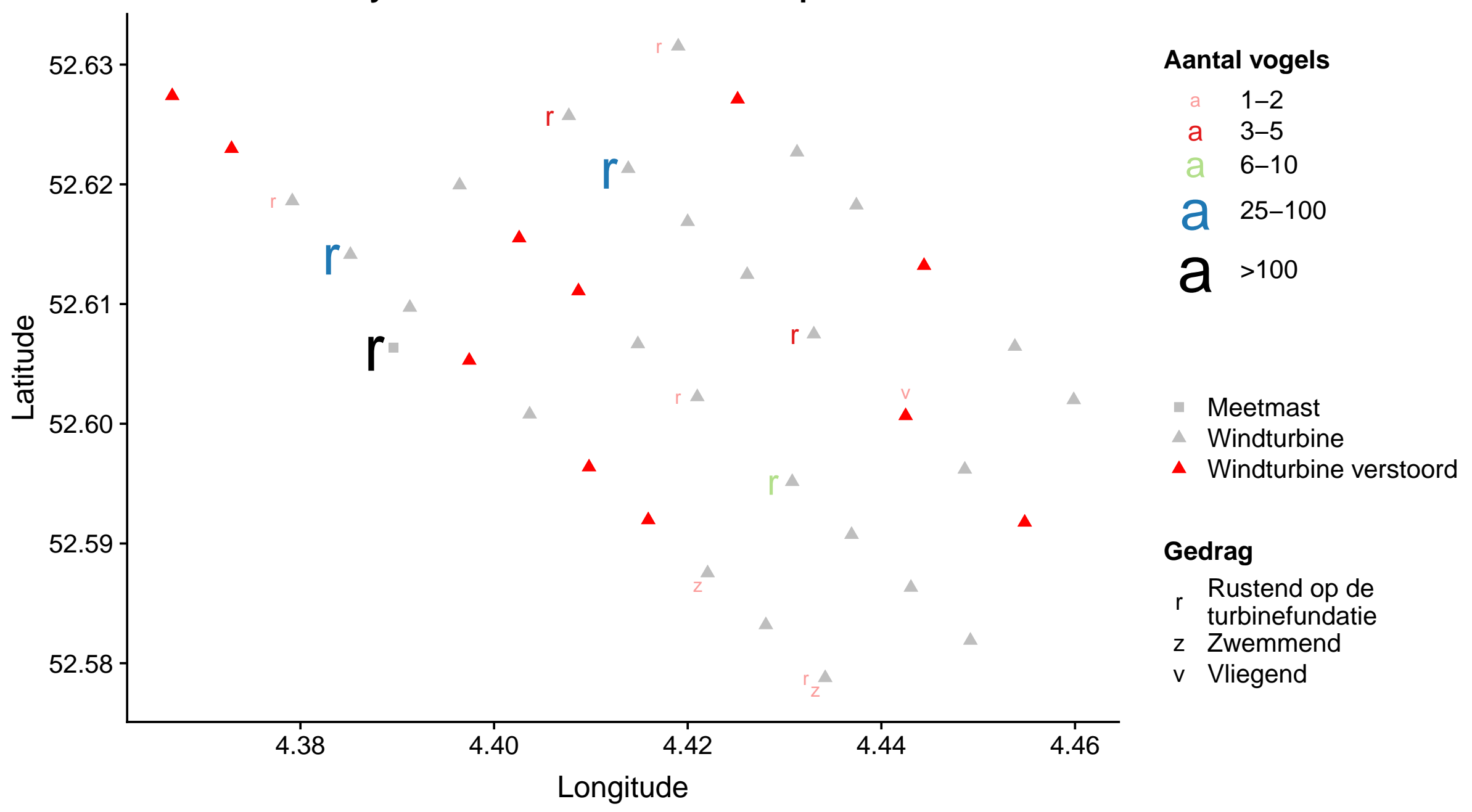




\section{Survey 3: Aalscholver in windmolenpark PAWP}

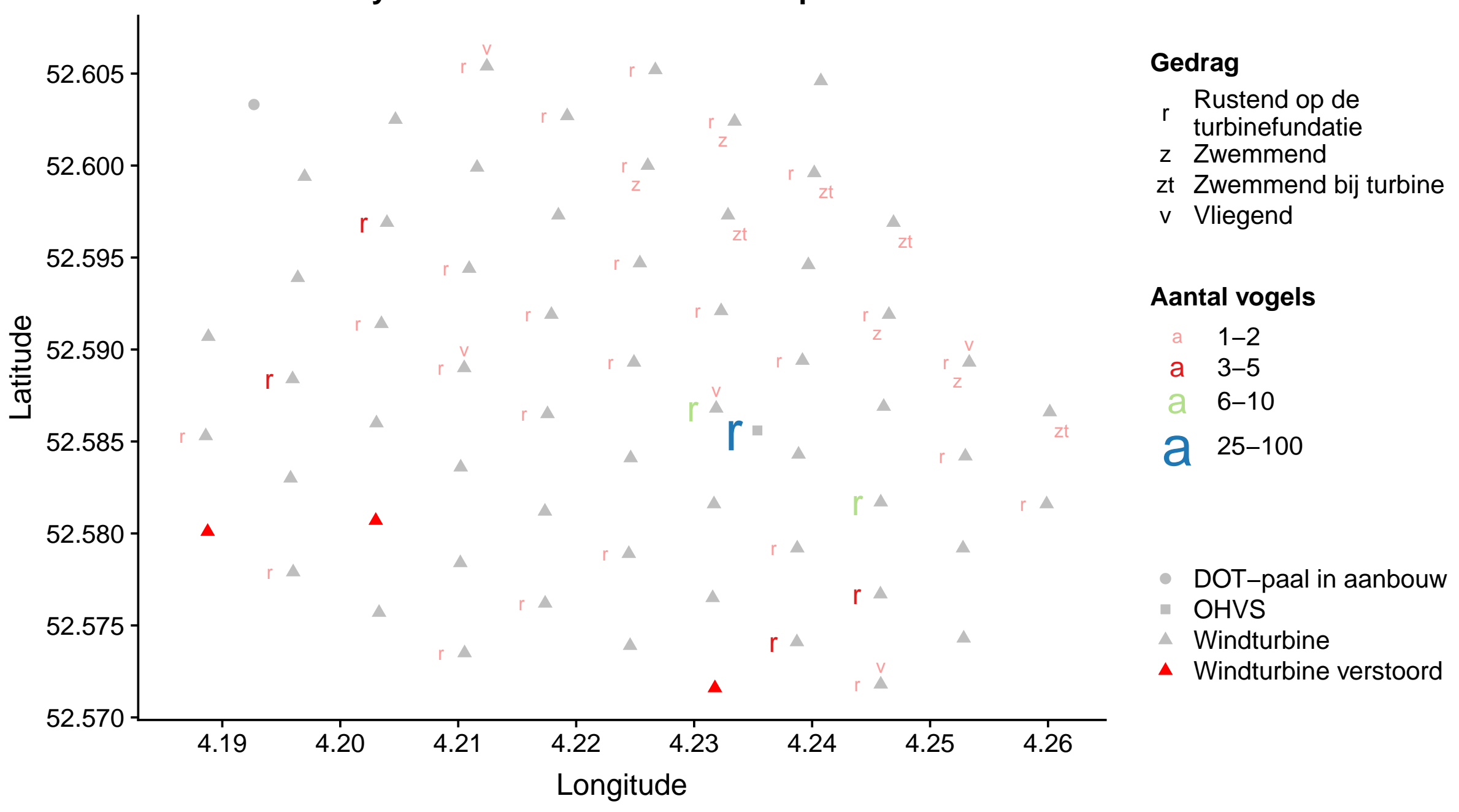




\section{Survey 3: Aalscholver in windmolenpark LUD}

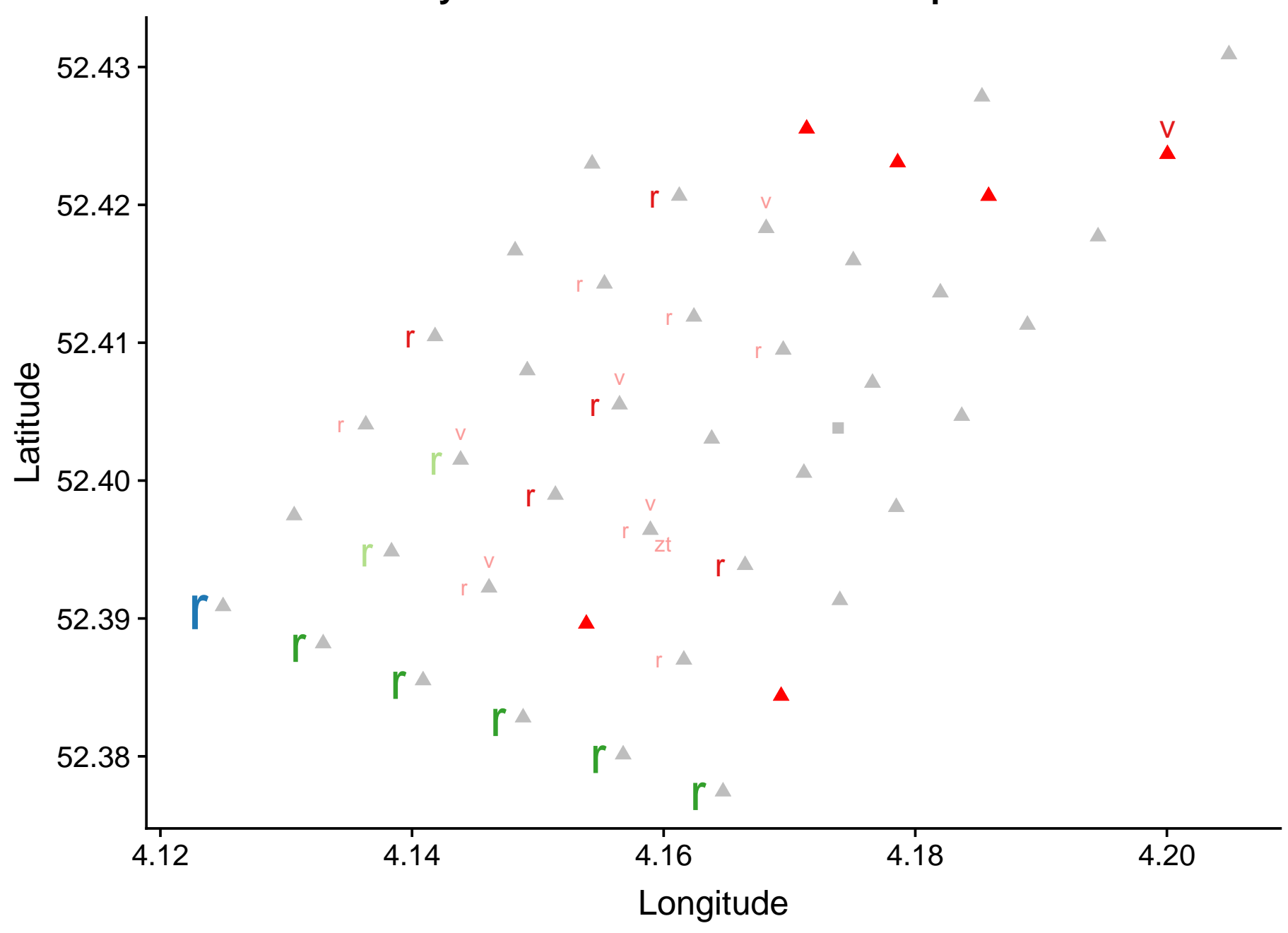

- OHVS

$\triangle$ Windturbine

- Windturbine verstoord

\section{Gedrag}

Rustend op de

turbinefundatie

zt Zwemmend bij turbine

$v$ Vliegend

\section{Aantal vogels}
a 1-2
a $3-5$
2. $6-10$
a $11-25$
a 25-100 
Survey 4: Aalscholver in windmolenpark OWEZ

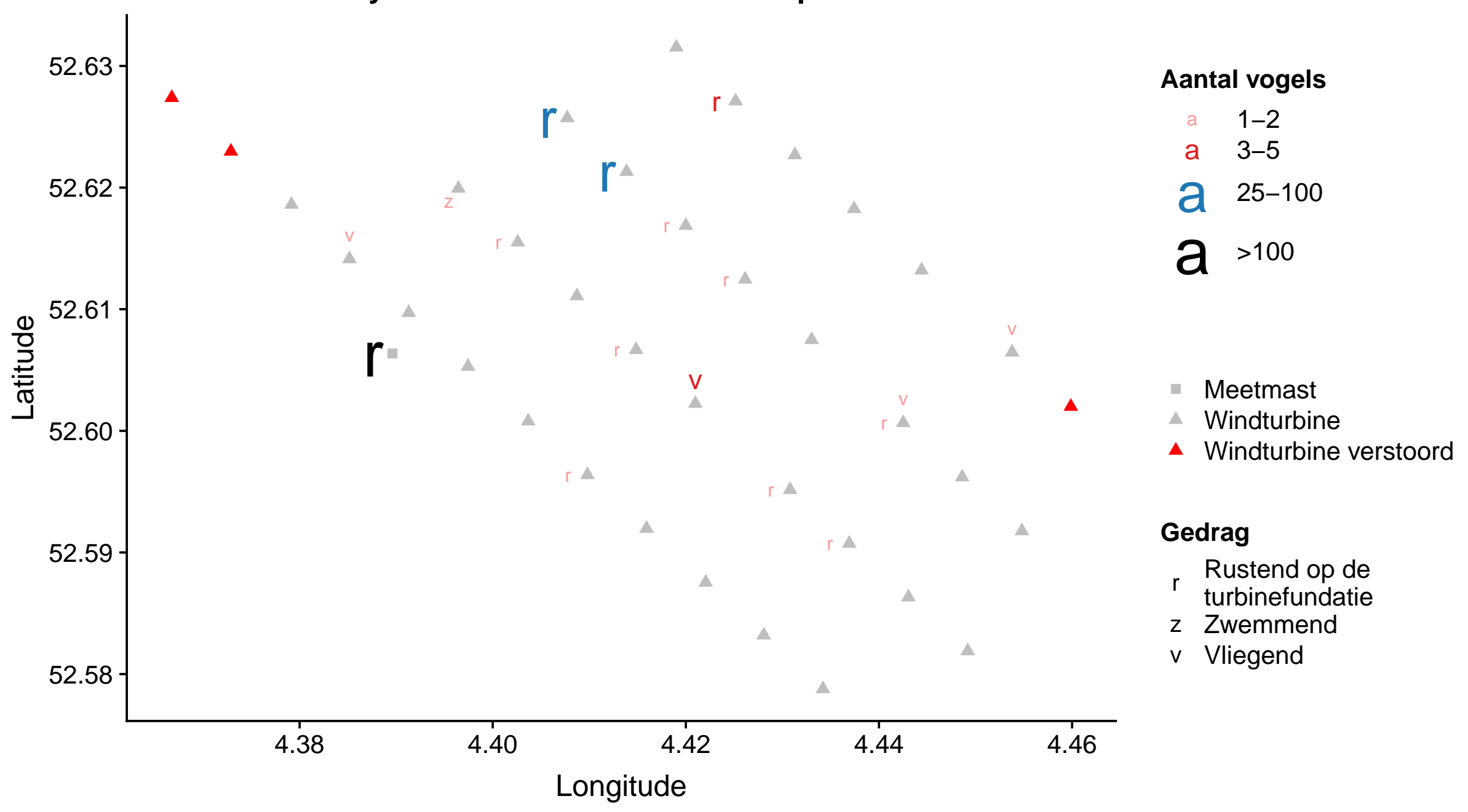




\section{Survey 4: Aalscholver in windmolenpark PAWP}

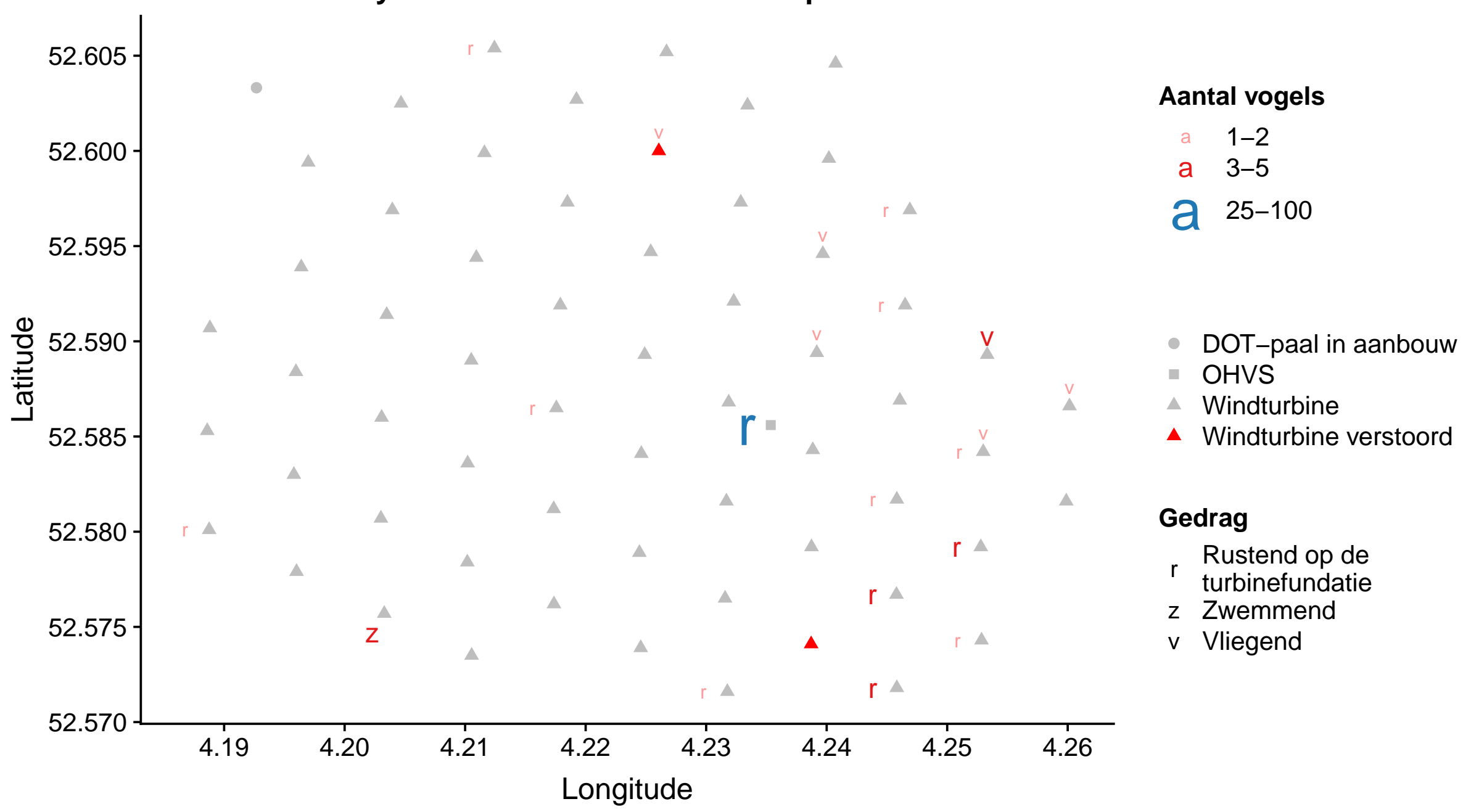




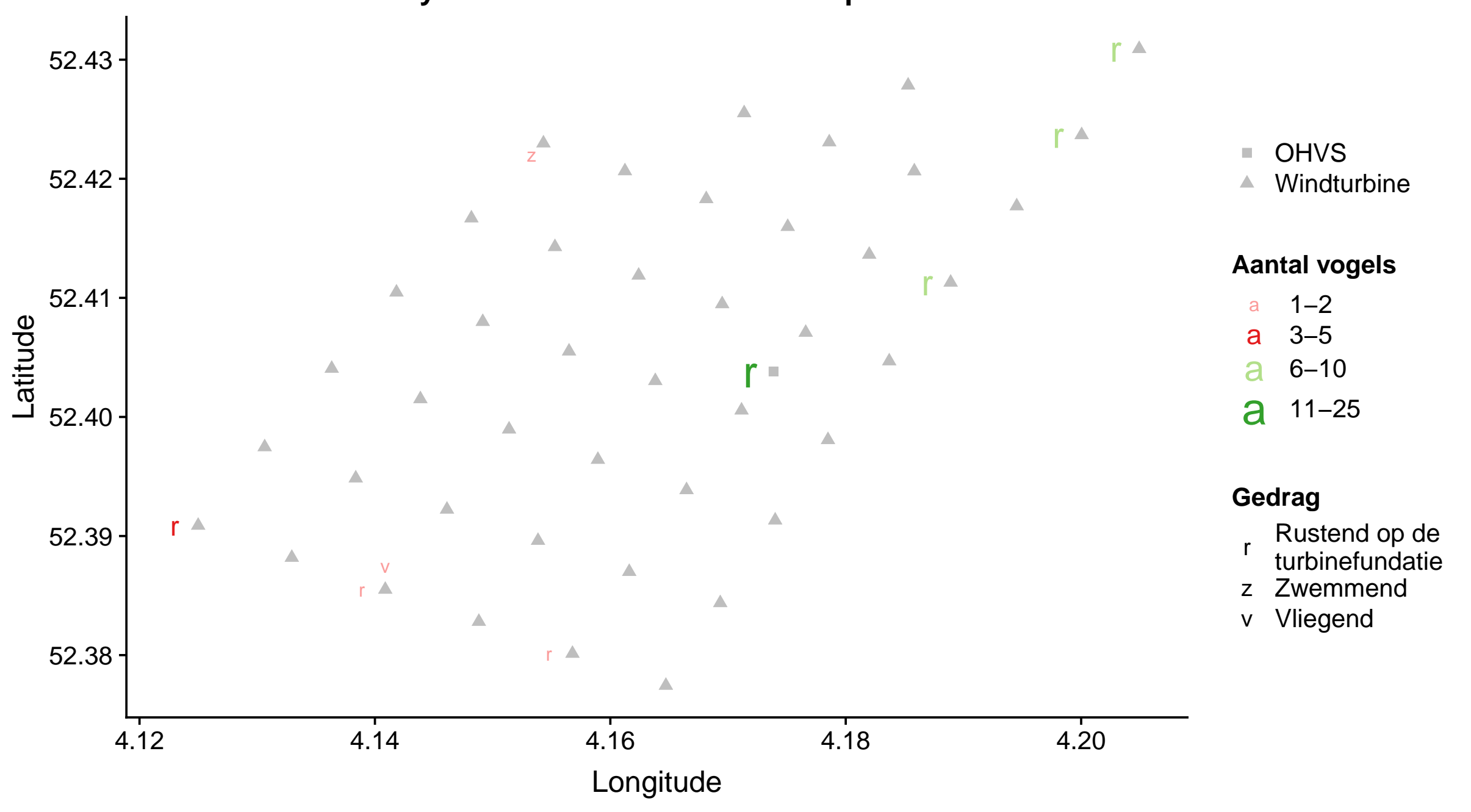


Survey 5: Aalscholver in windmolenpark OWEZ

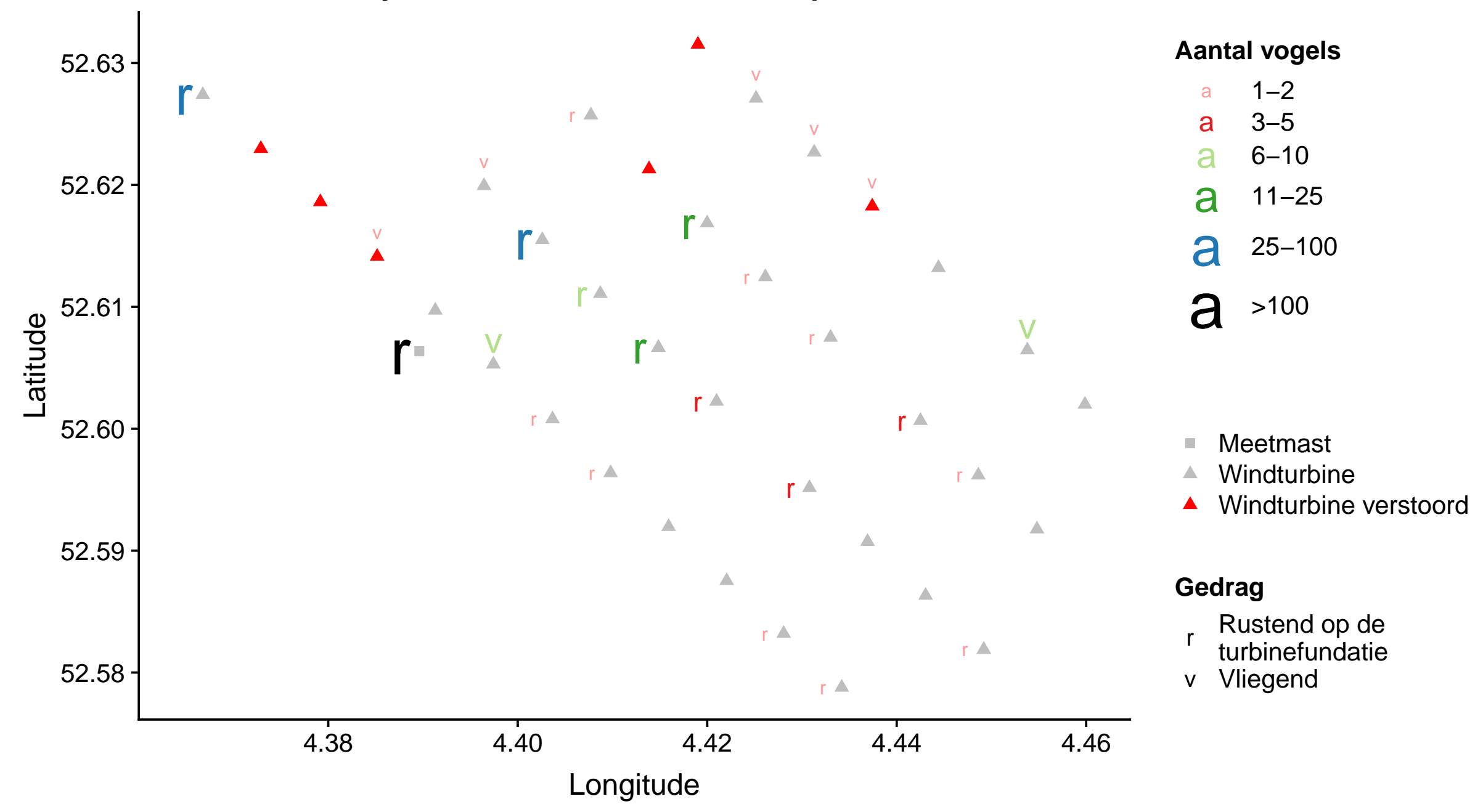


Survey 5: Aalscholver in windmolenpark PAWP

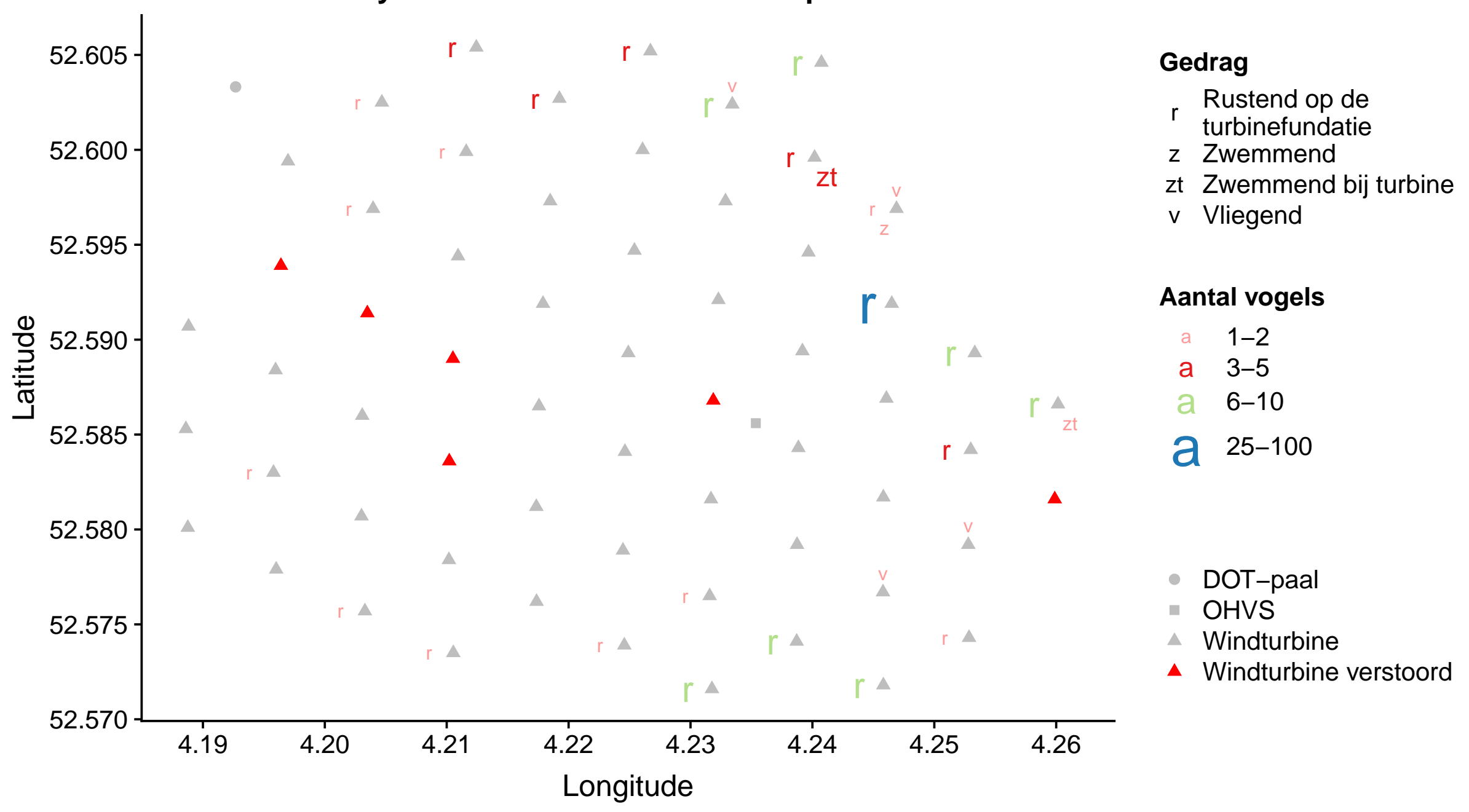


Survey 5: Aalscholver in windmolenpark LUD

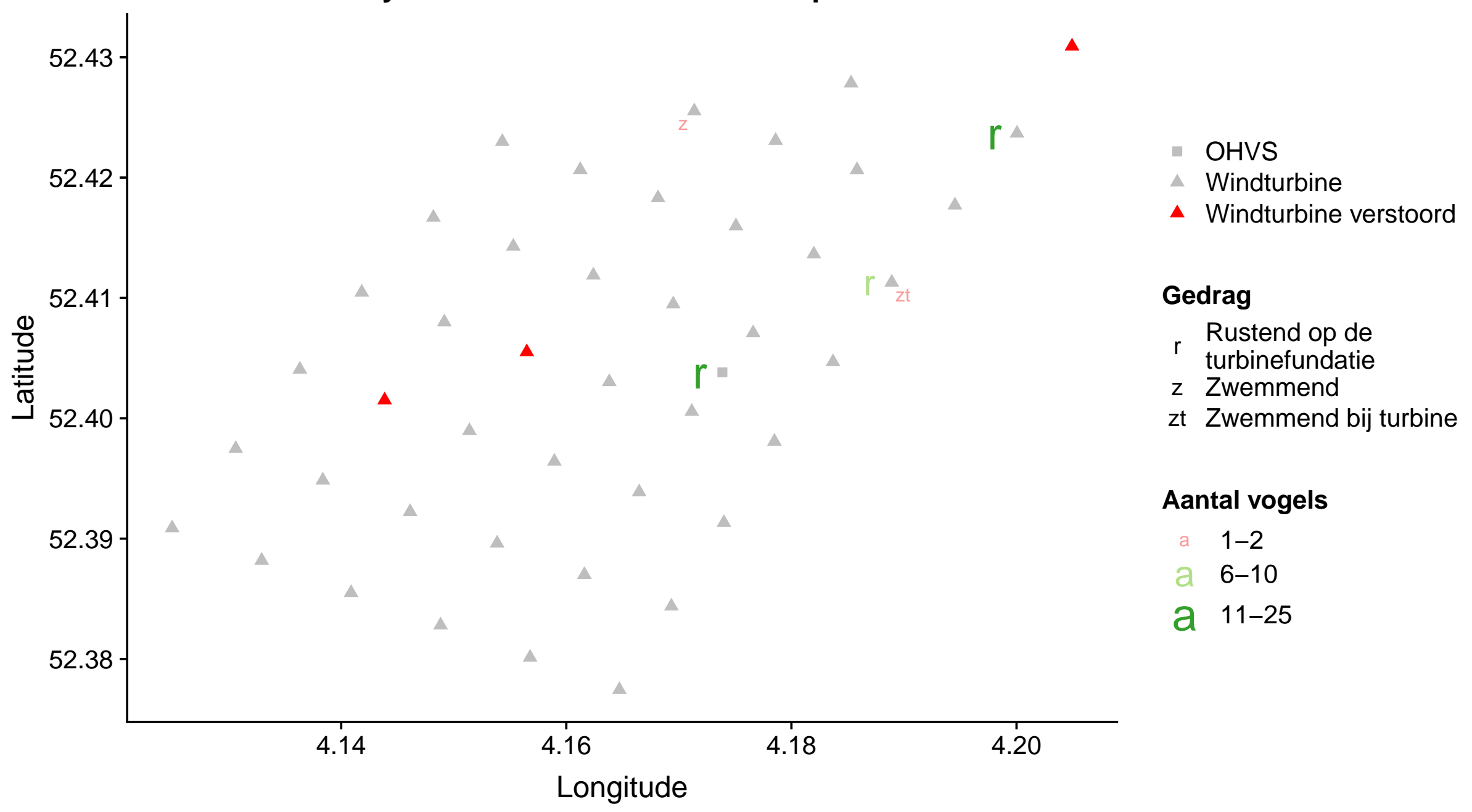




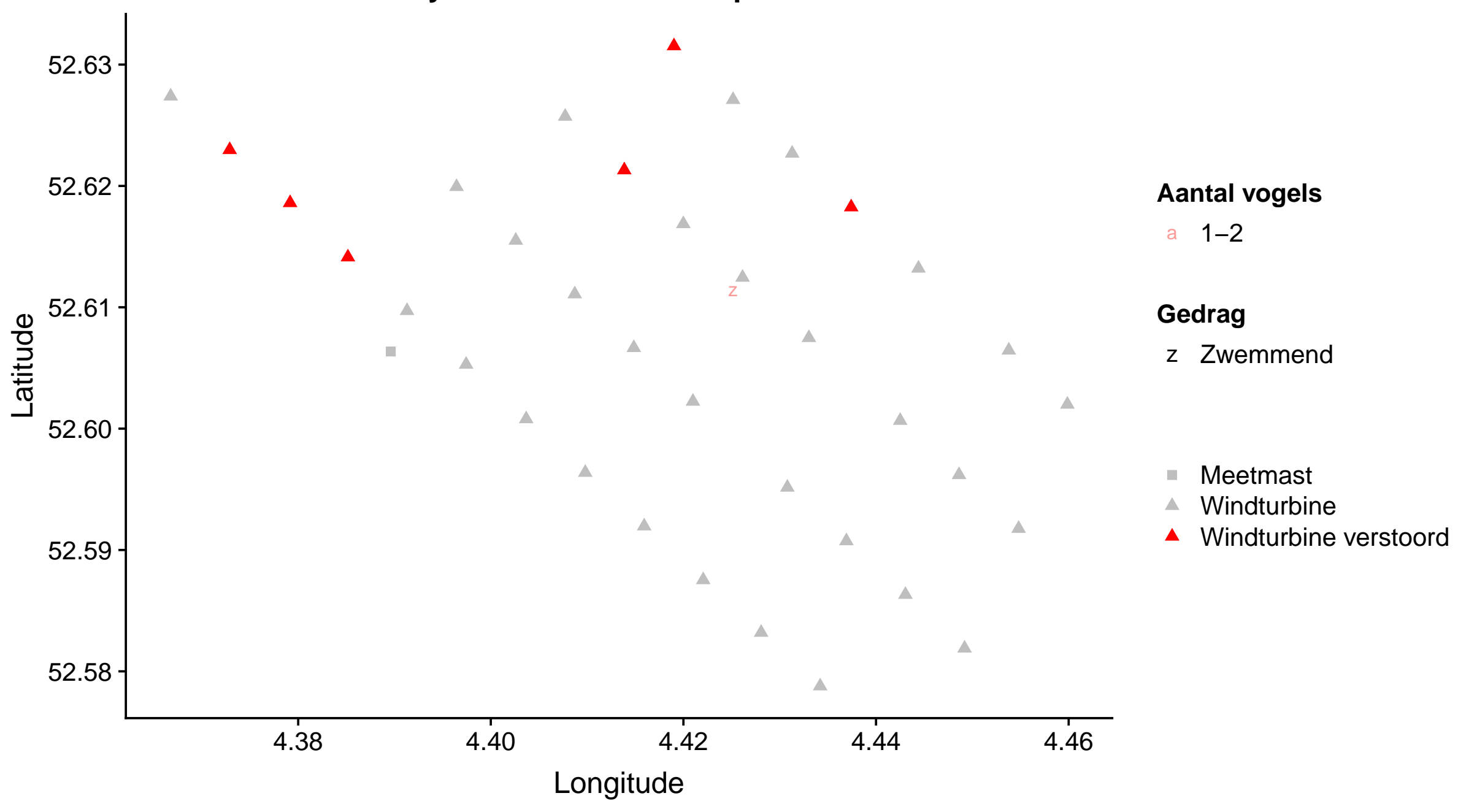


Survey 5: Blauwe reiger in windmolenpark LUD

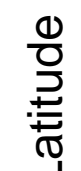

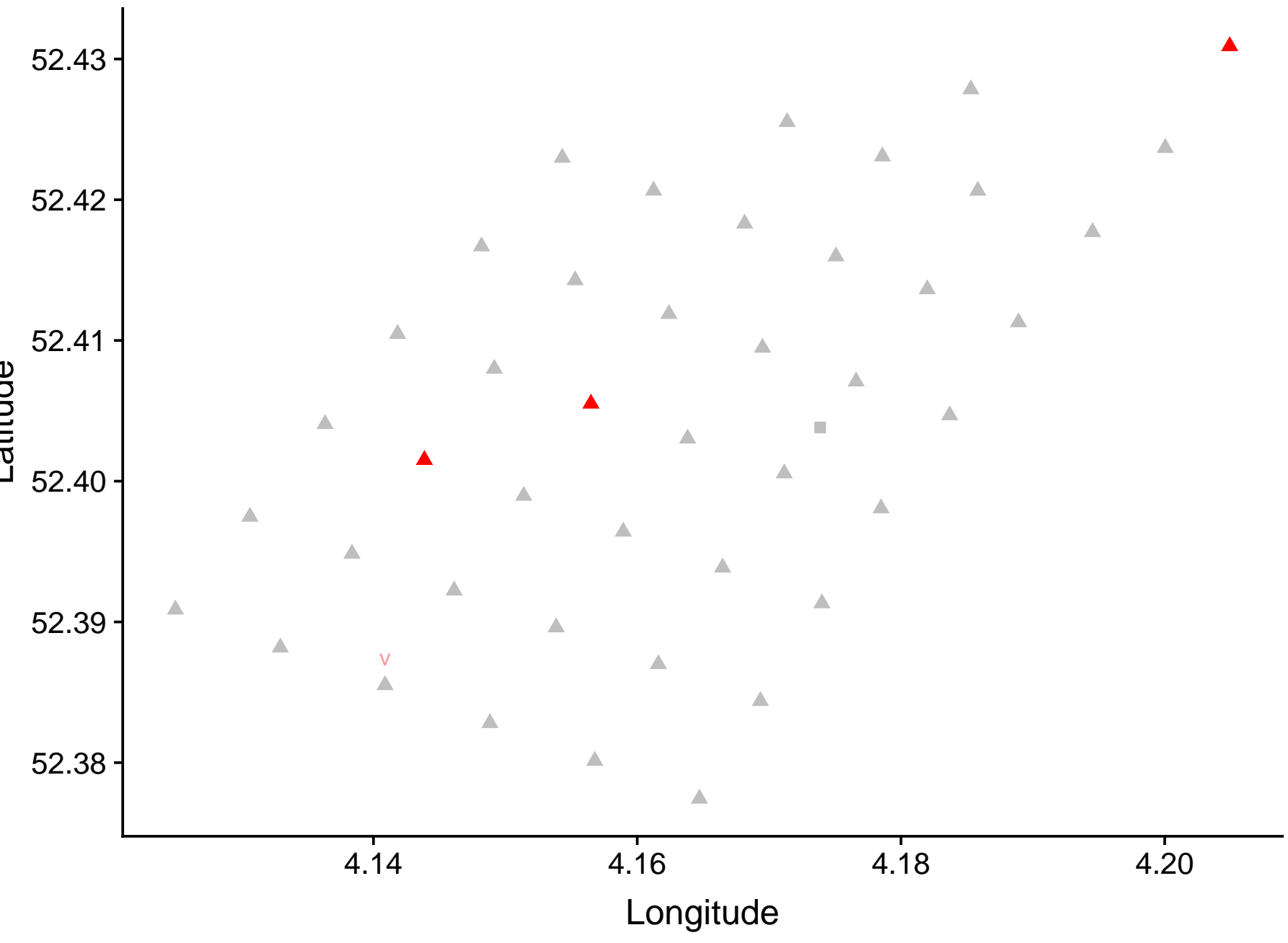

- OHVS

Windturbine

- Windturbine verstoord

Aantal vogels

a 1-2

Gedrag

v Vliegend 


\section{Survey 4: Drieteenmeeuw in windmolenpark LUD}

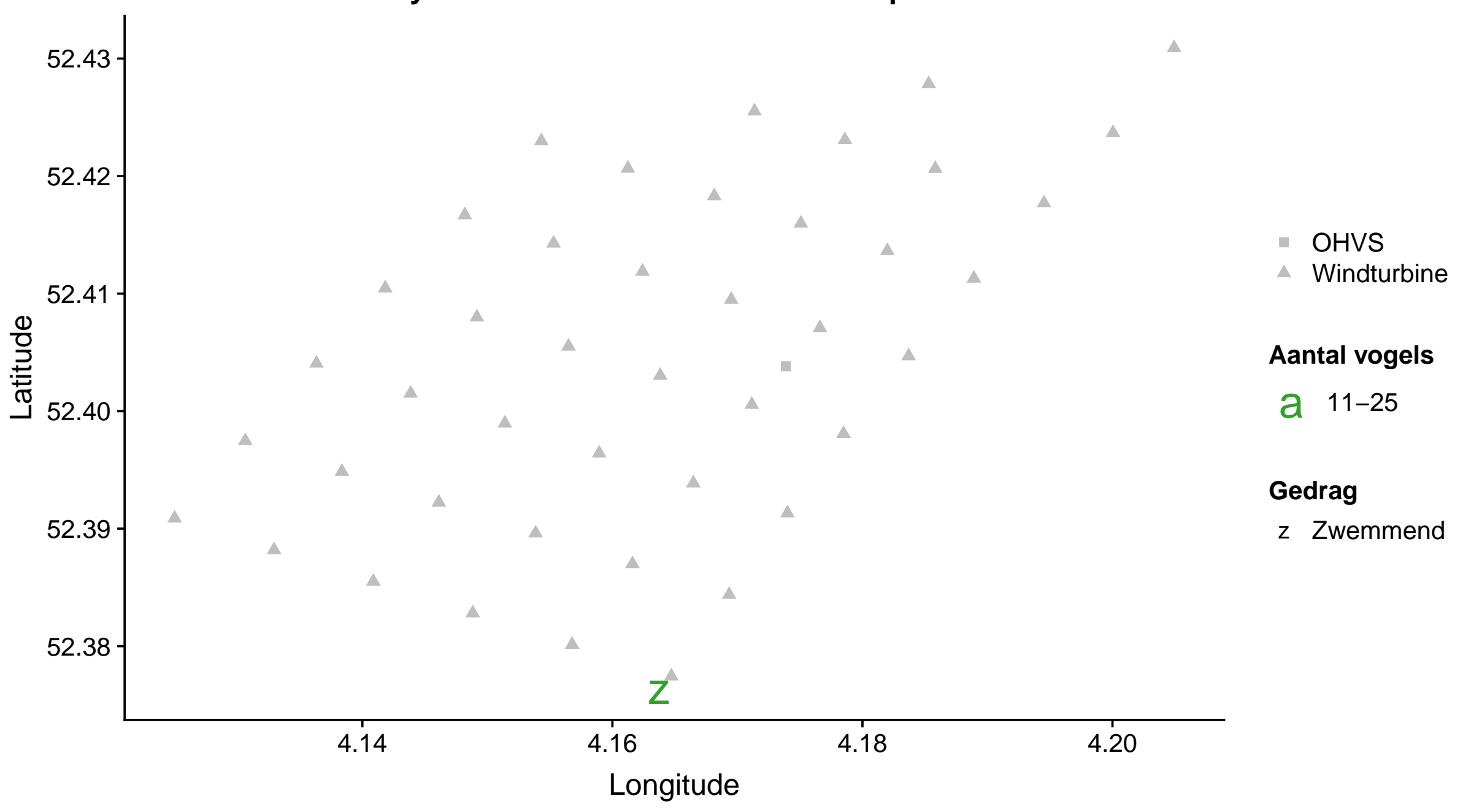


Survey 5: Drieteenmeeuw in windmolenpark OWEZ

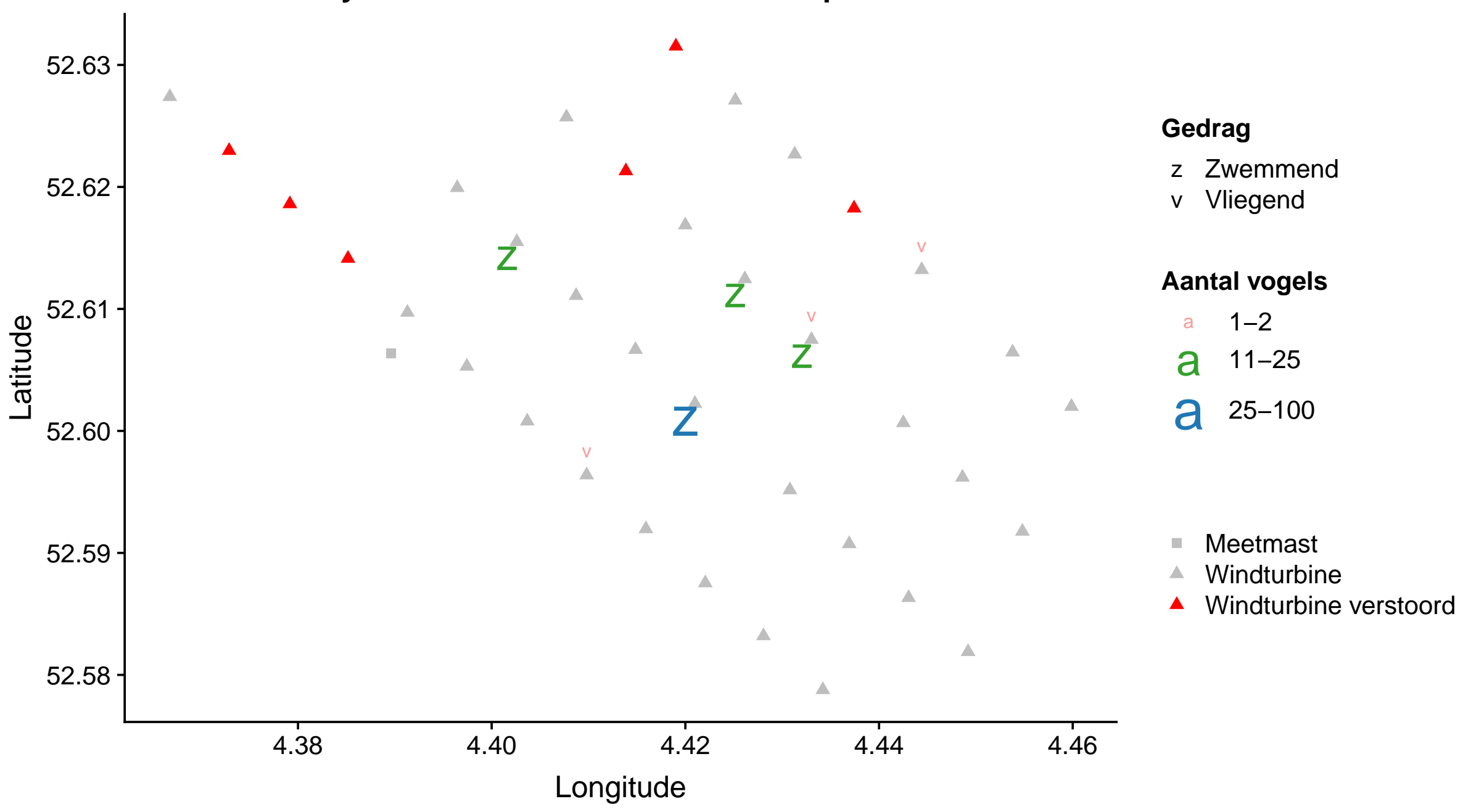


Survey 5: Drieteenmeeuw in windmolenpark LUD

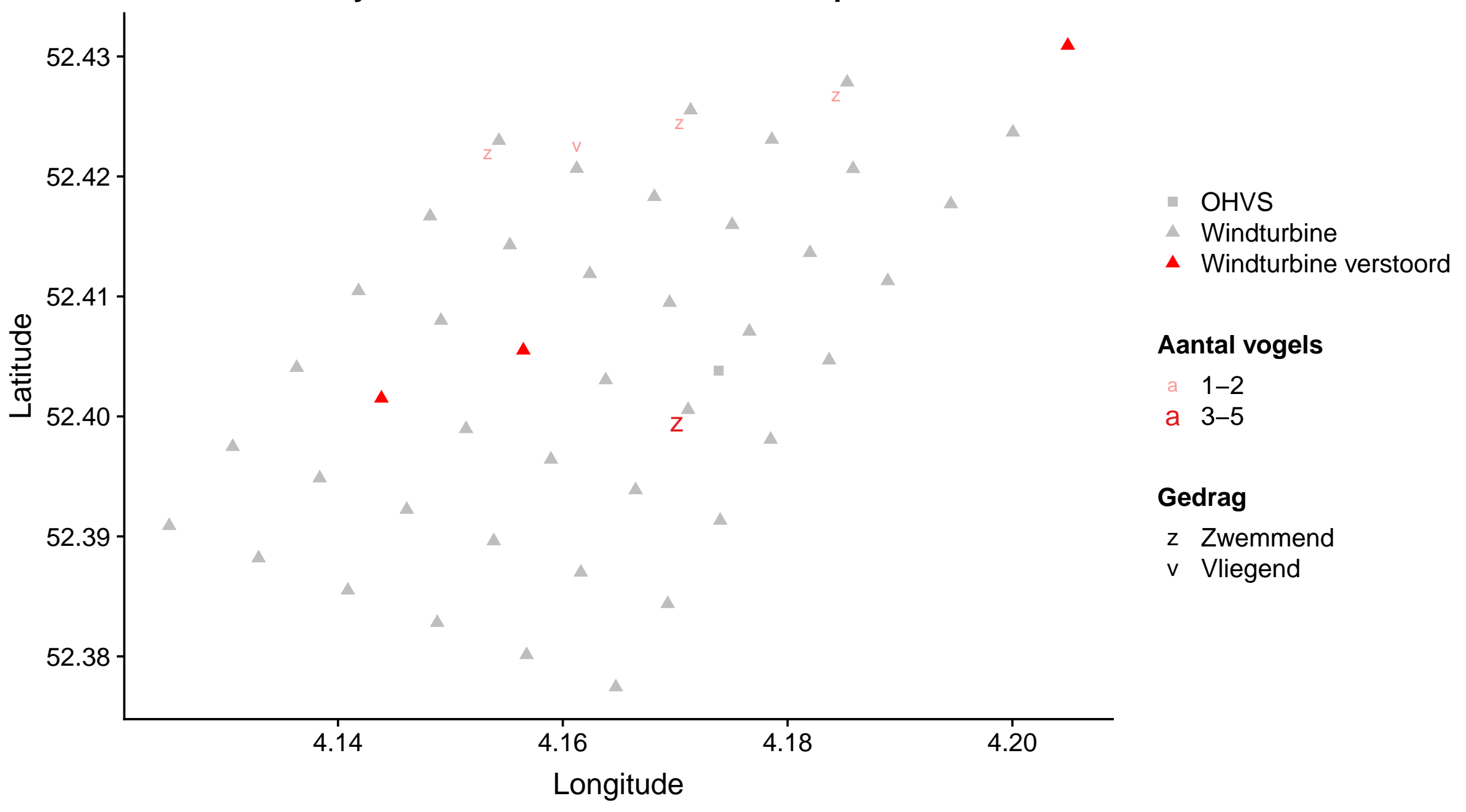




\section{Survey 4: Graspieper in windmolenpark OWEZ}

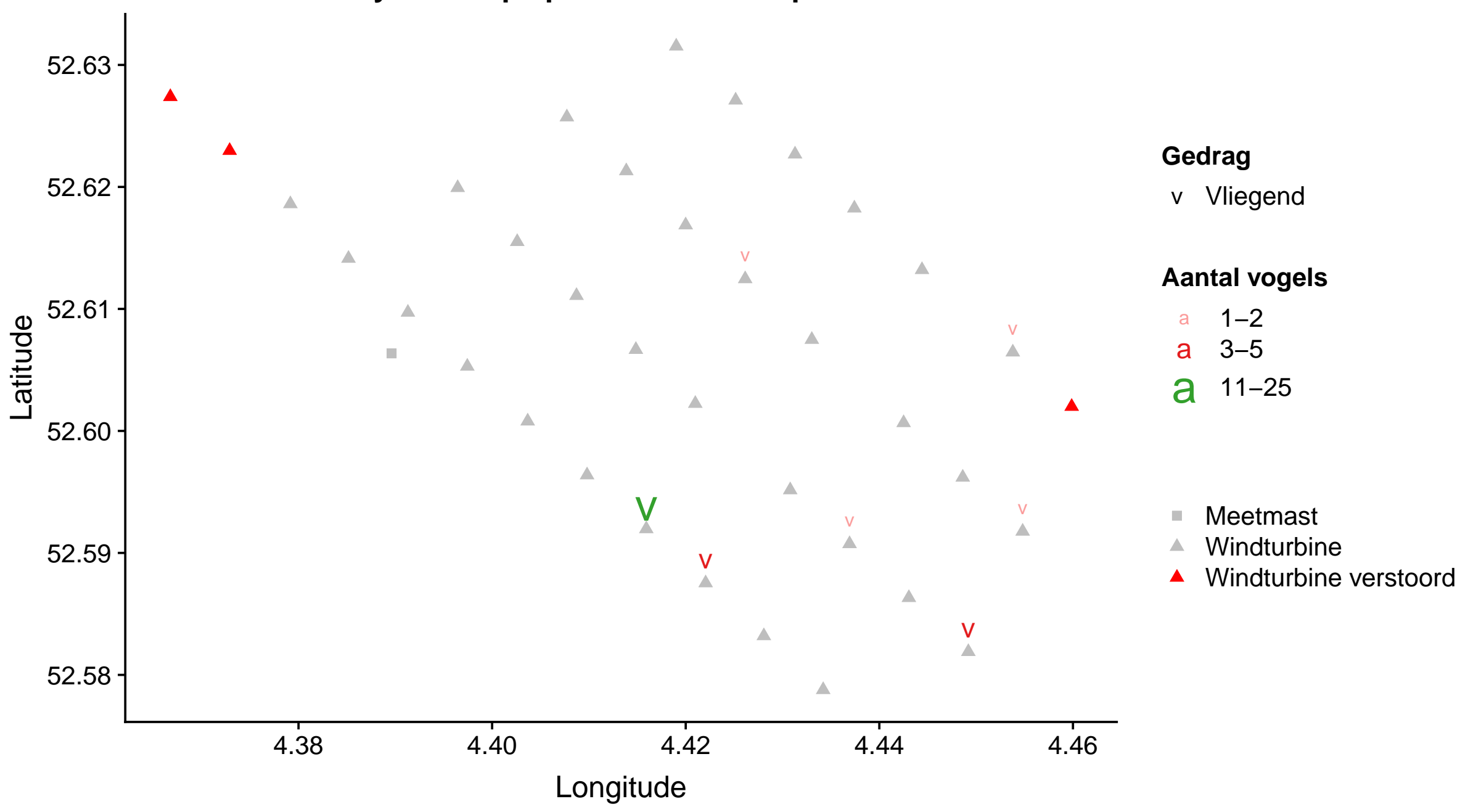


Survey 5: Graspieper in windmolenpark LUD

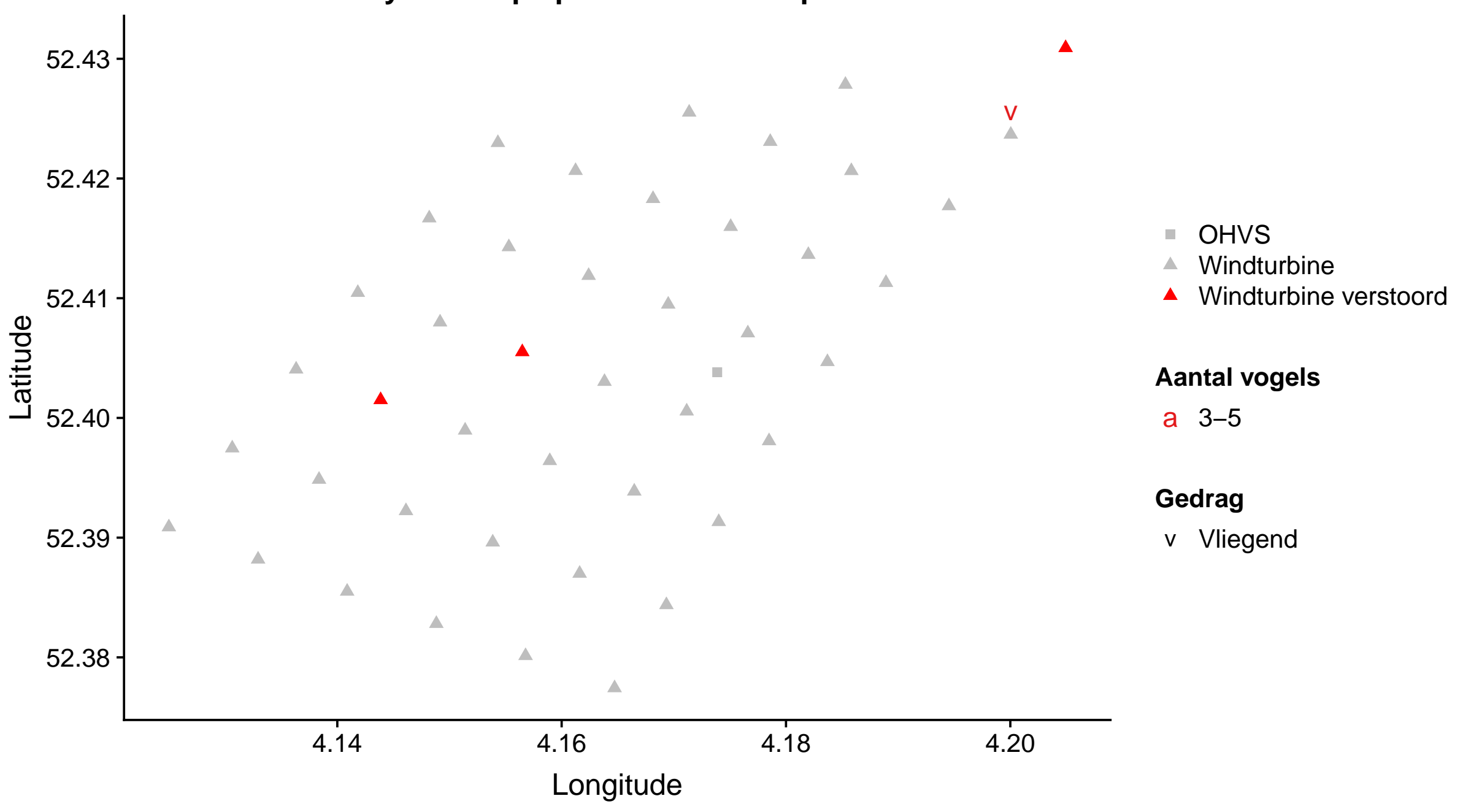




\section{Survey 5: Graspieper in windmolenpark OWEZ}

$\frac{9}{0}$

52.61

$\Delta$

$\Delta$

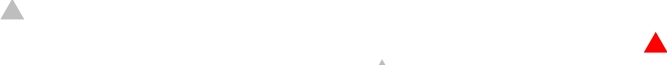

$\Delta$

Aantal vogels

2 6-10

$\Delta$
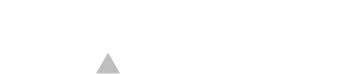

$\Delta$

Gedrag

v Vliegend

- Meetmast

$\Delta$ Windturbine

- Windturbine verstoord 


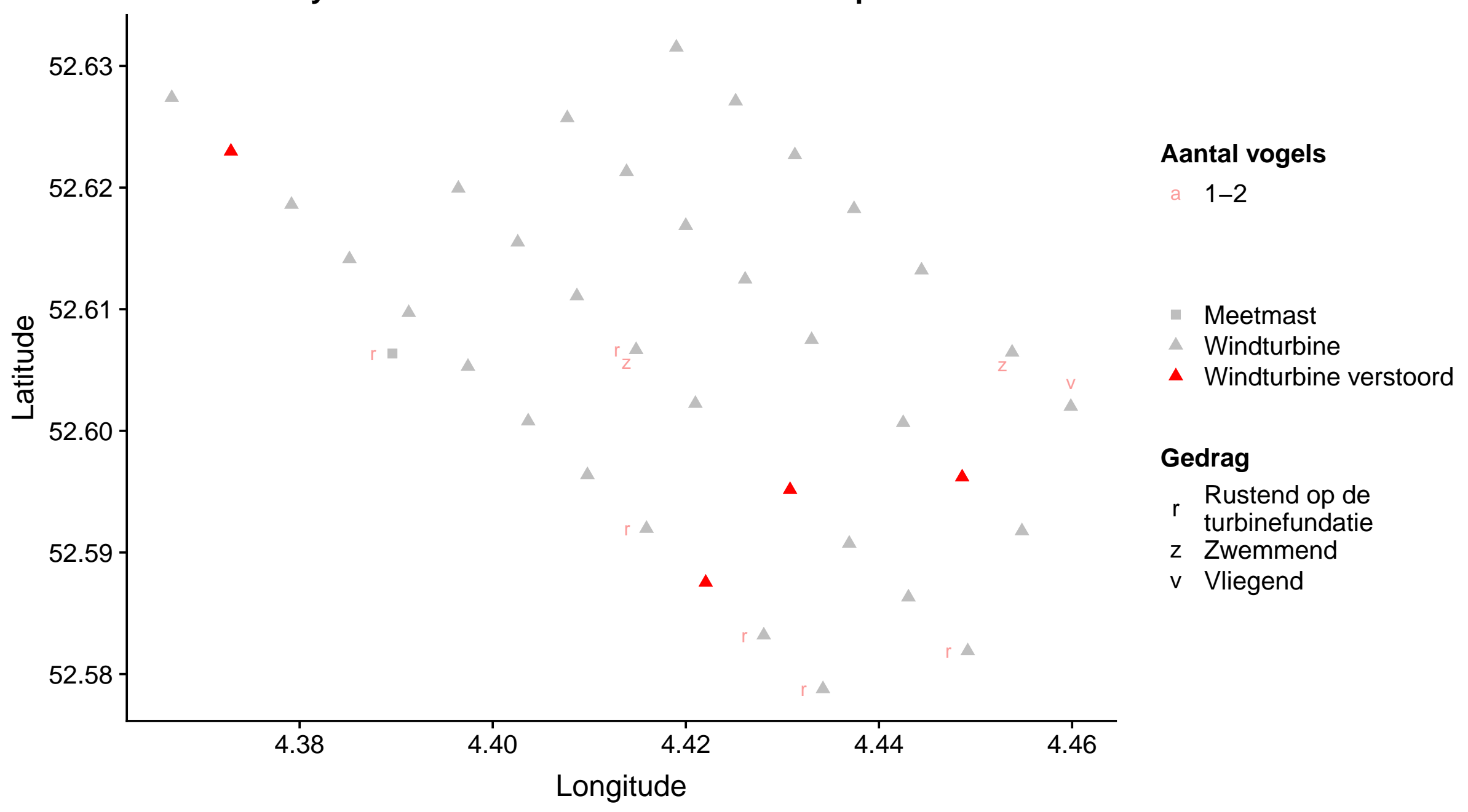


Survey 2: Grote mantelmeeuw in windmolenpark PAWP

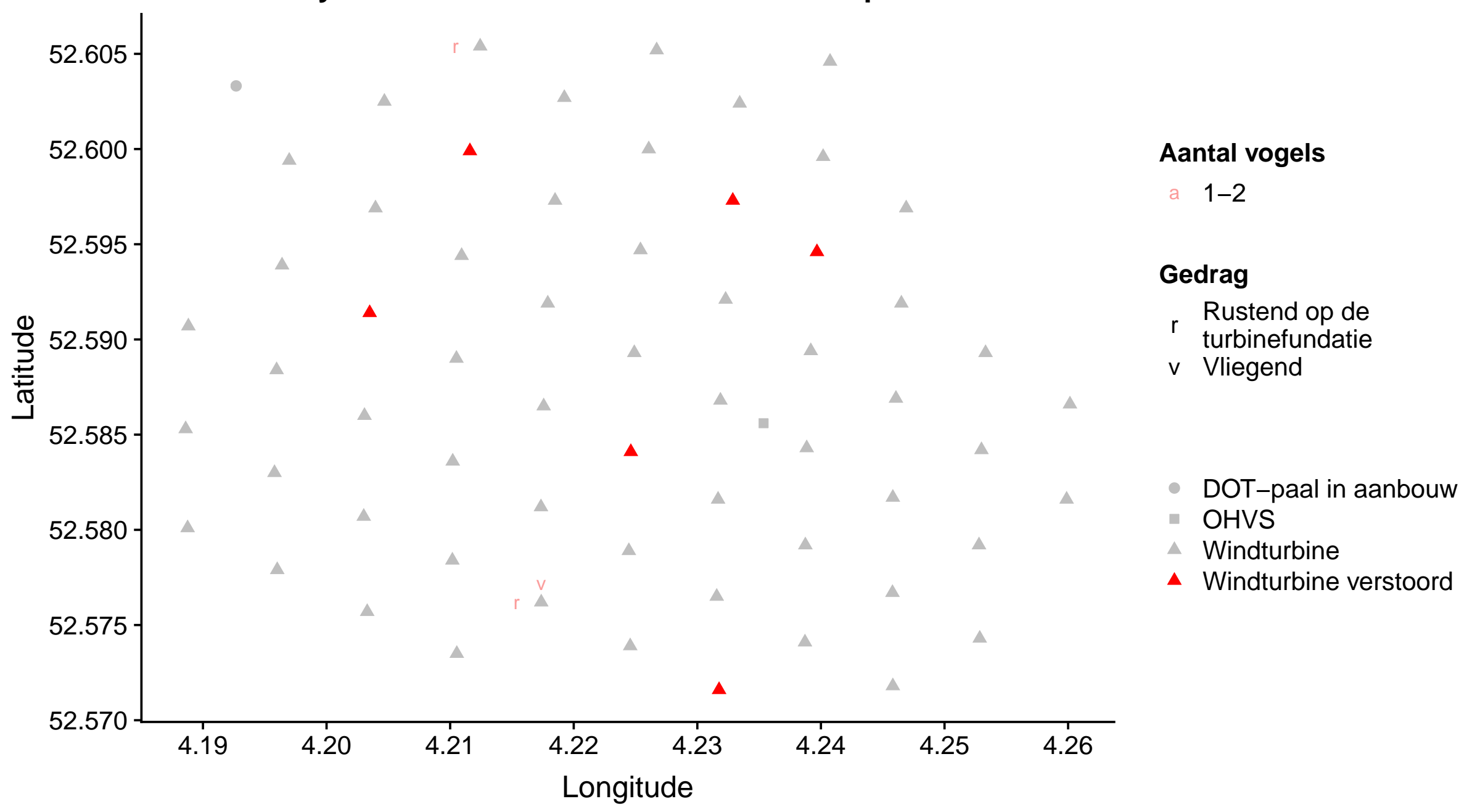


Survey 2: Grote mantelmeeuw in windmolenpark LUD

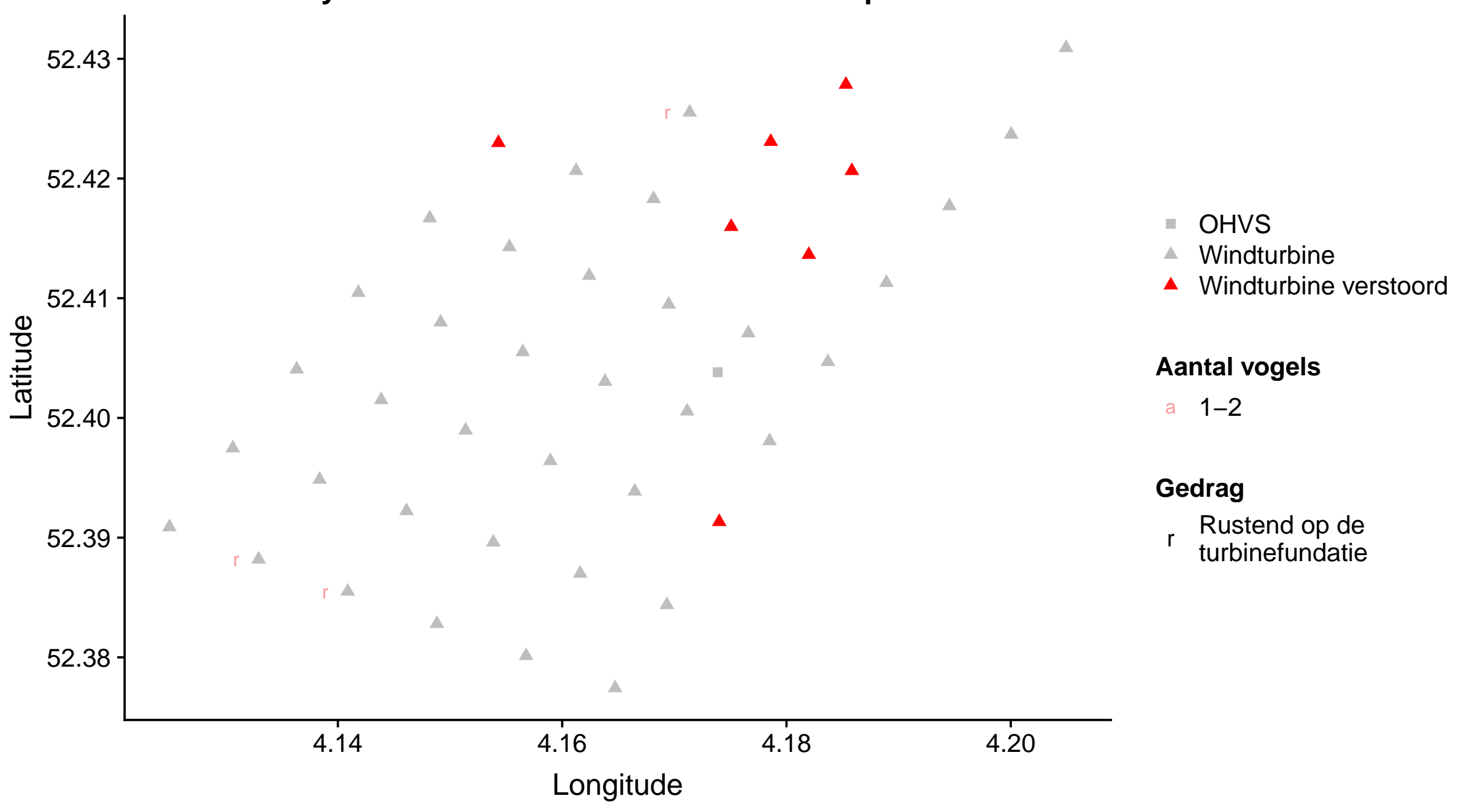




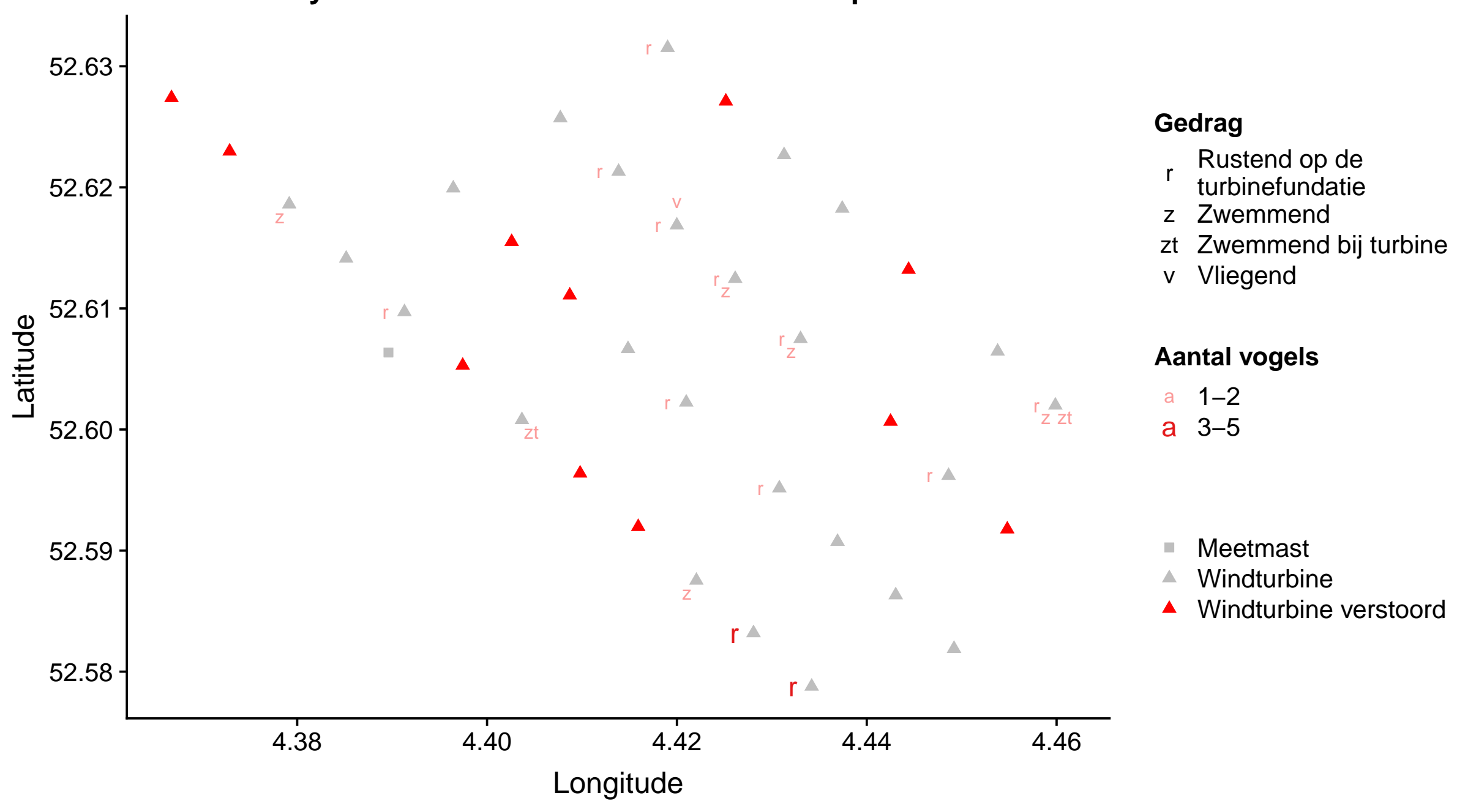


Survey 3: Grote mantelmeeuw in windmolenpark PAWP

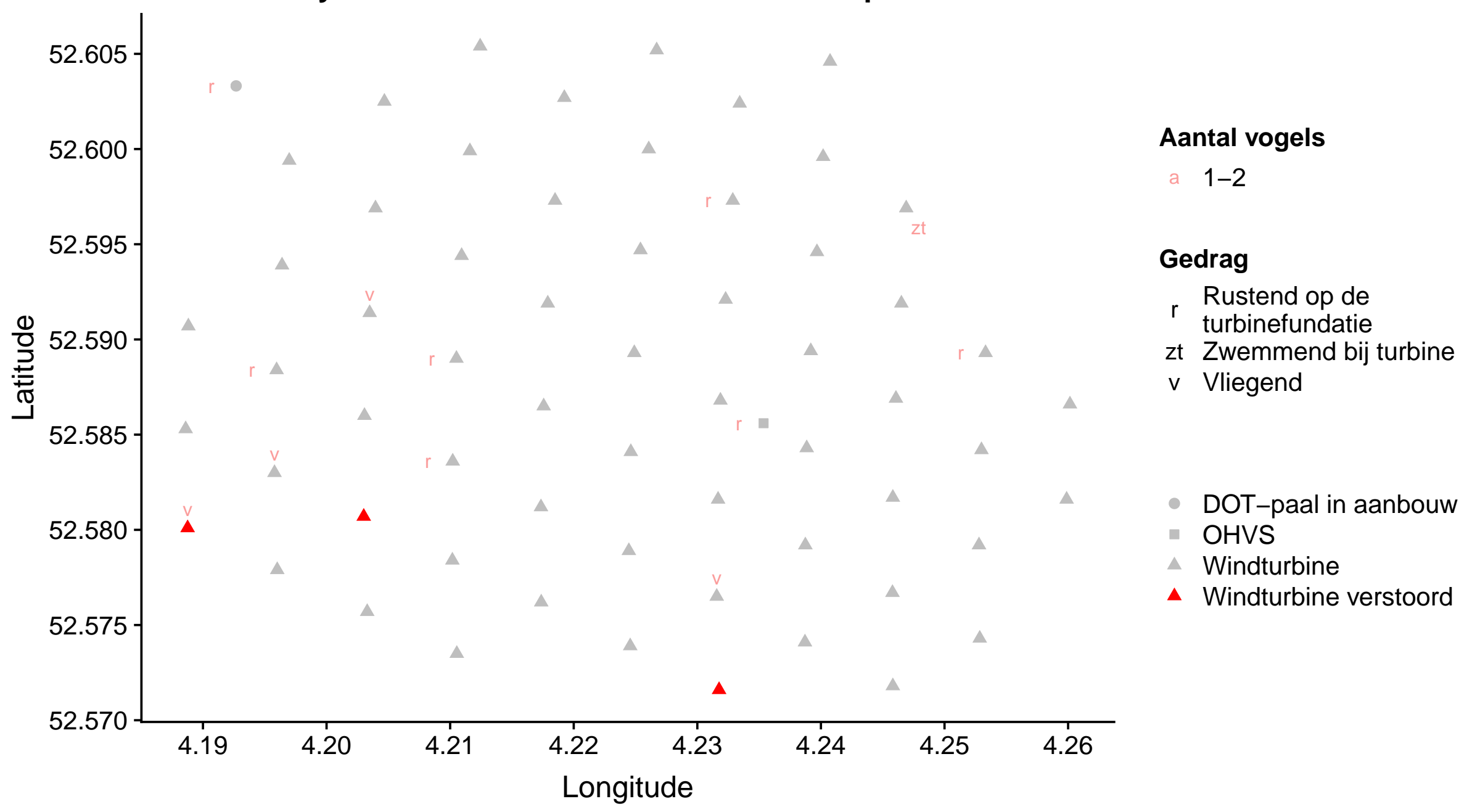


Survey 3: Grote mantelmeeuw in windmolenpark LUD

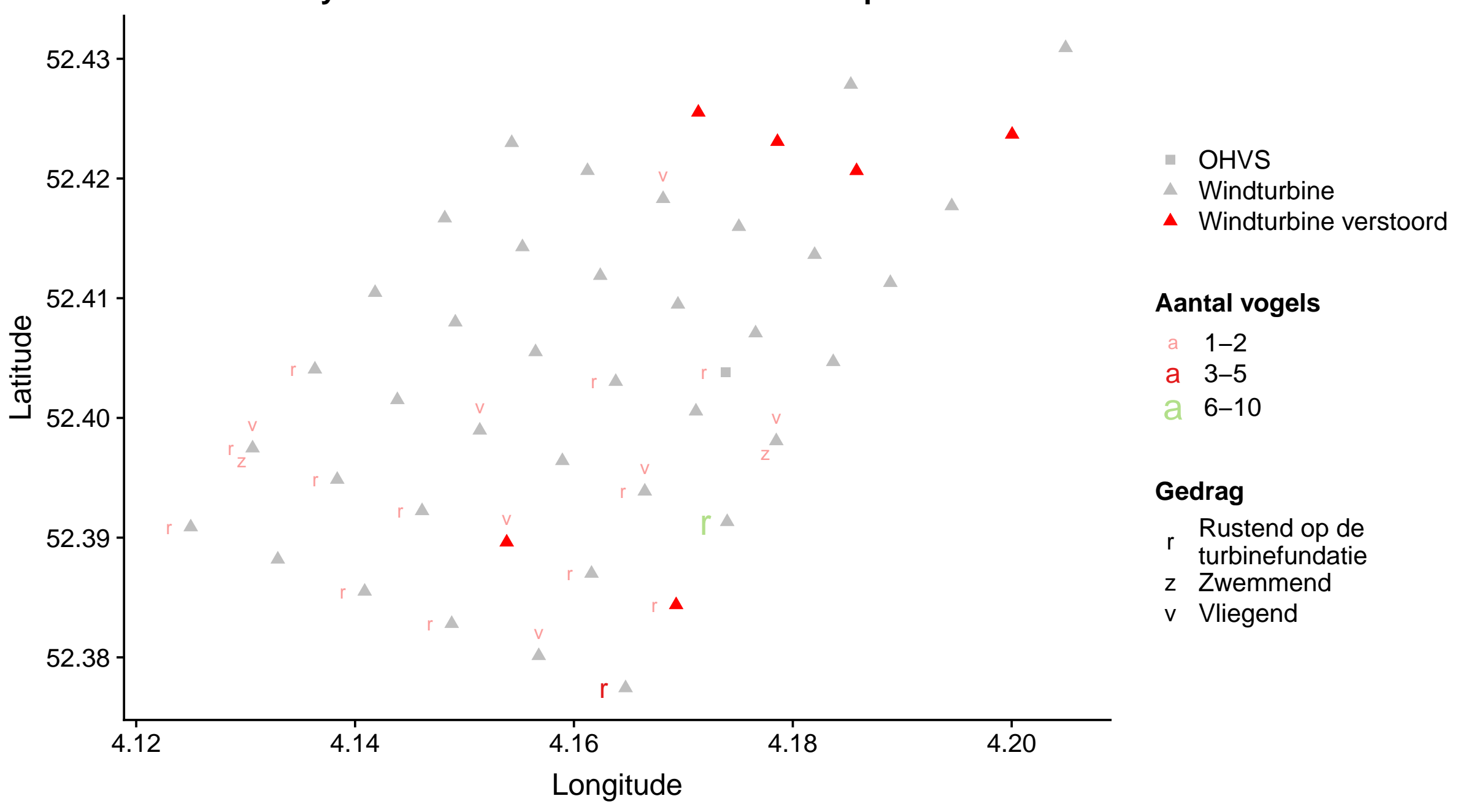


Survey 4: Grote mantelmeeuw in windmolenpark OWEZ

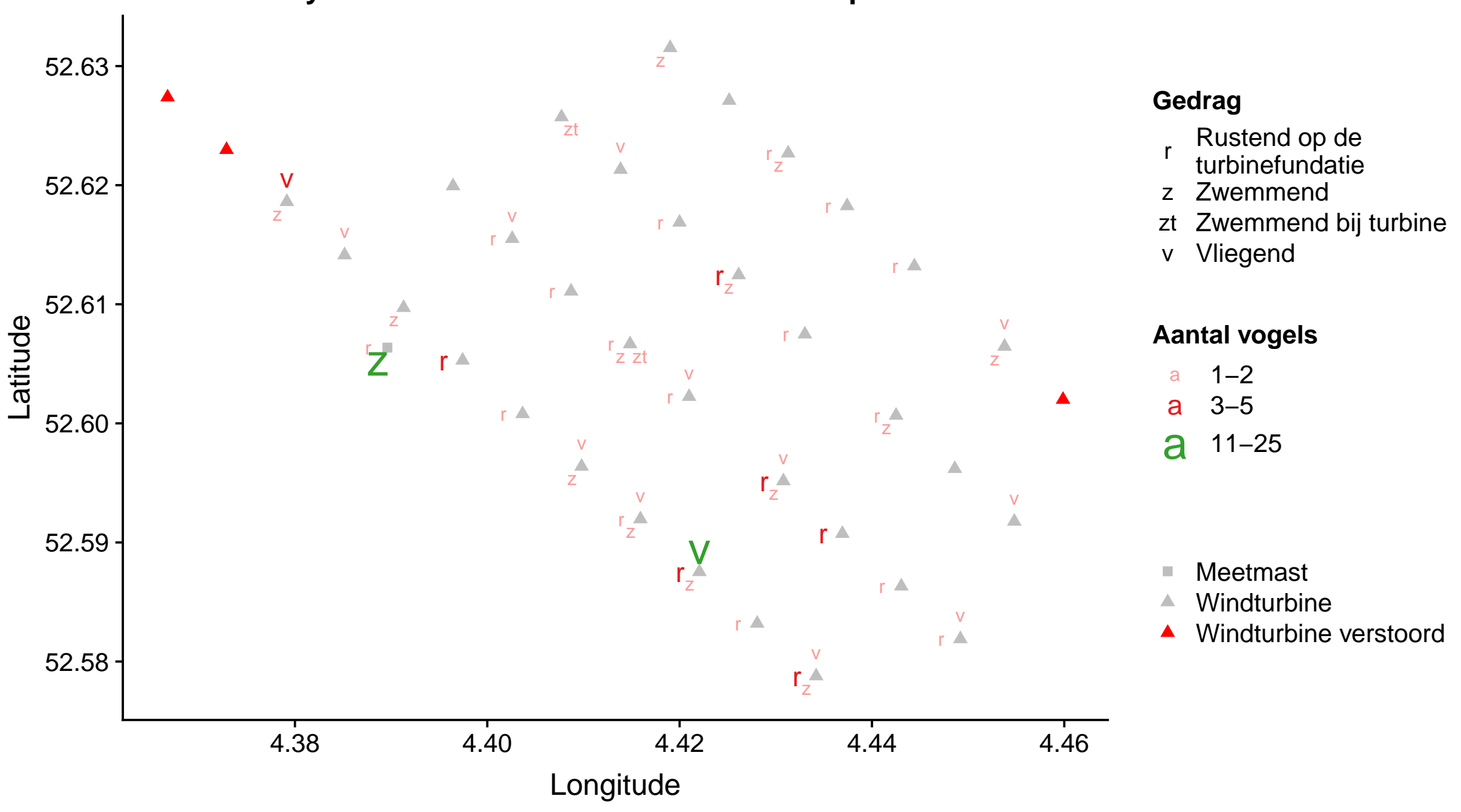


Survey 4: Grote mantelmeeuw in windmolenpark PAWP

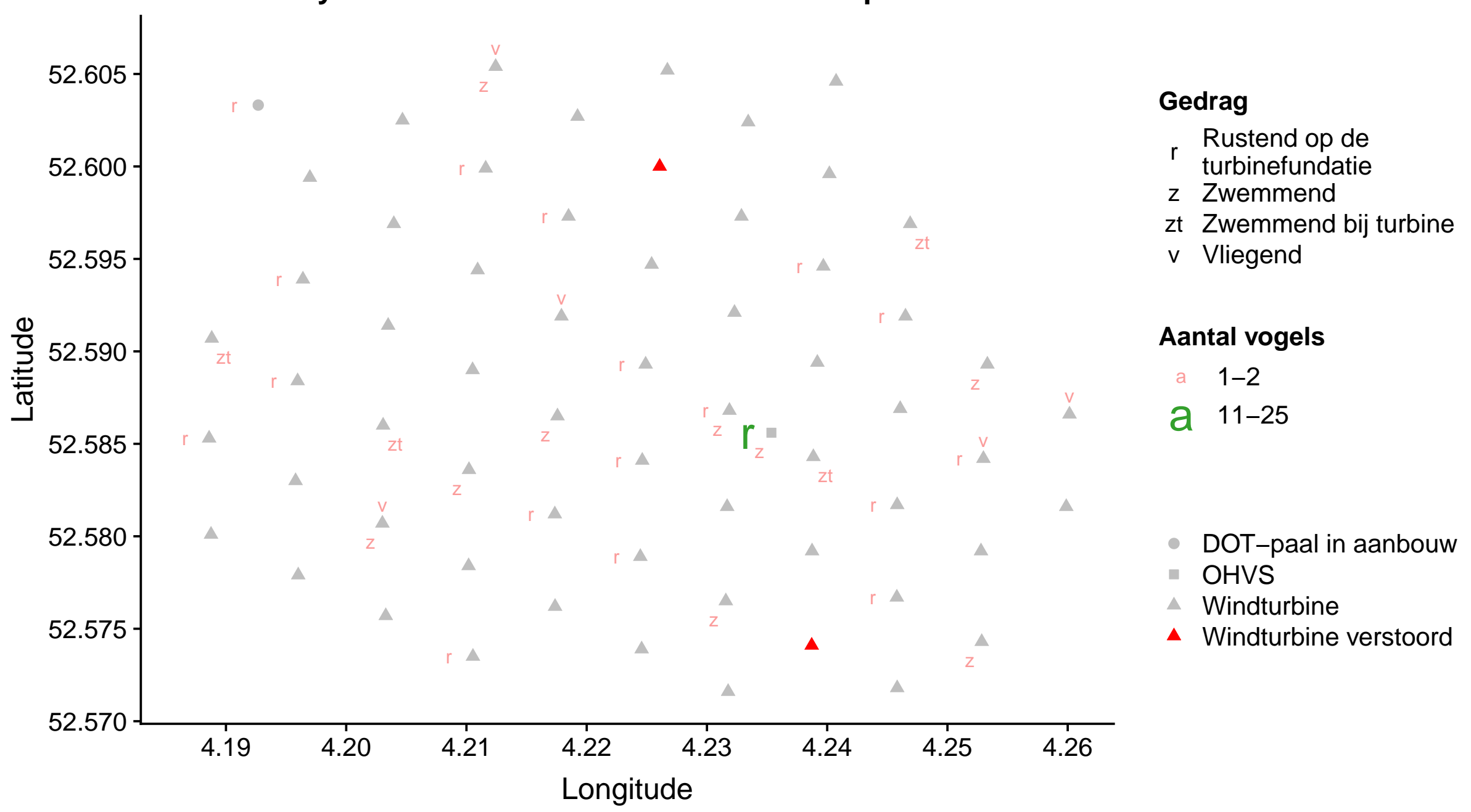




\section{Survey 4: Grote mantelmeeuw in windmolenpark LUD}

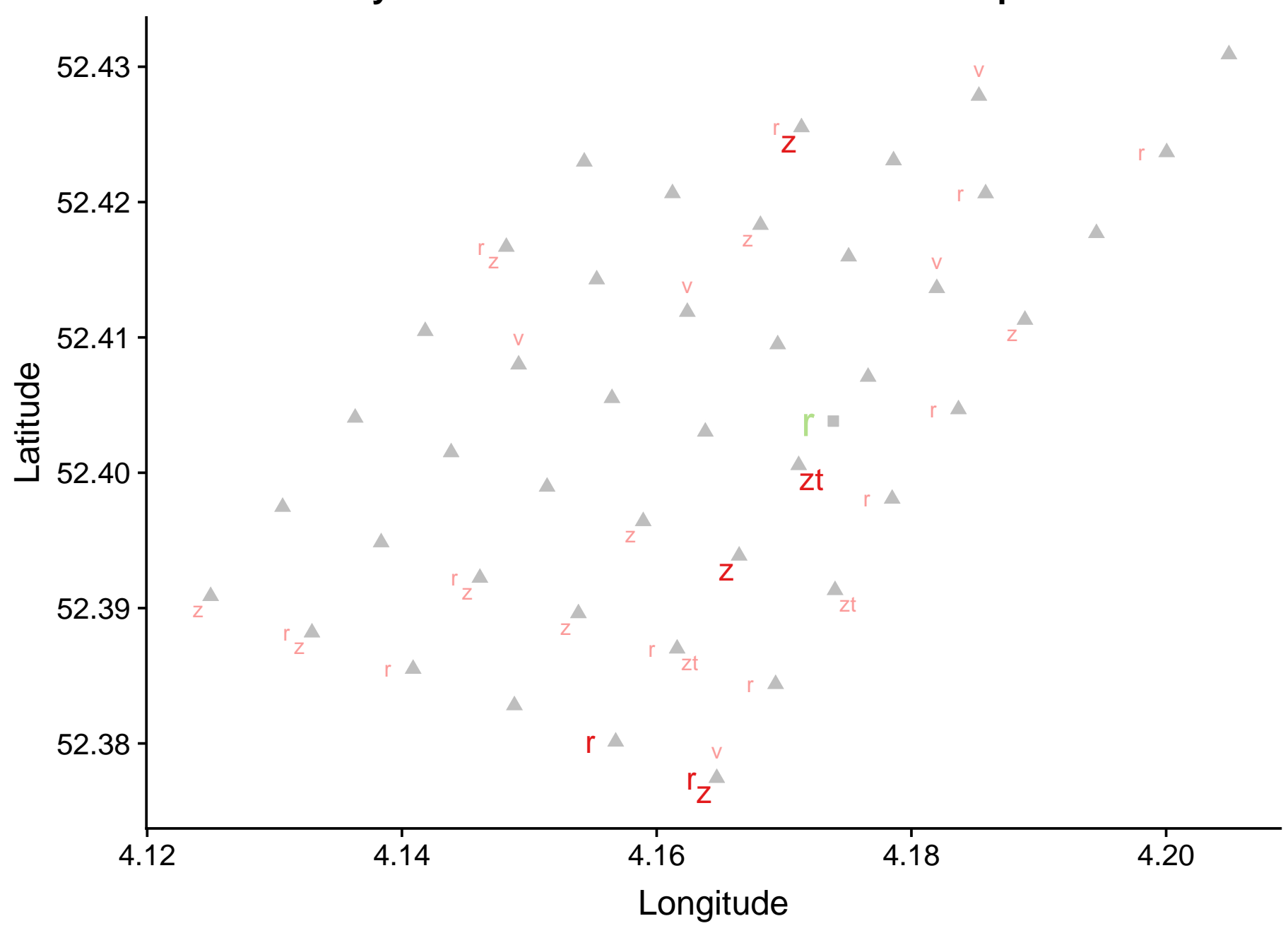

- OHVS

$\triangle$ Windturbine

\section{Gedrag}

Rustend op de

turbinefundatie

z Zwemmend

zt Zwemmend bij turbine

$v$ Vliegend

\section{Aantal vogels}
a 1-2
a $3-5$
a. $6-10$ 


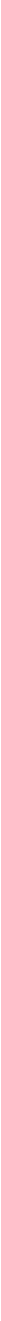


Survey 5: Grote mantelmeeuw in windmolenpark PAWP

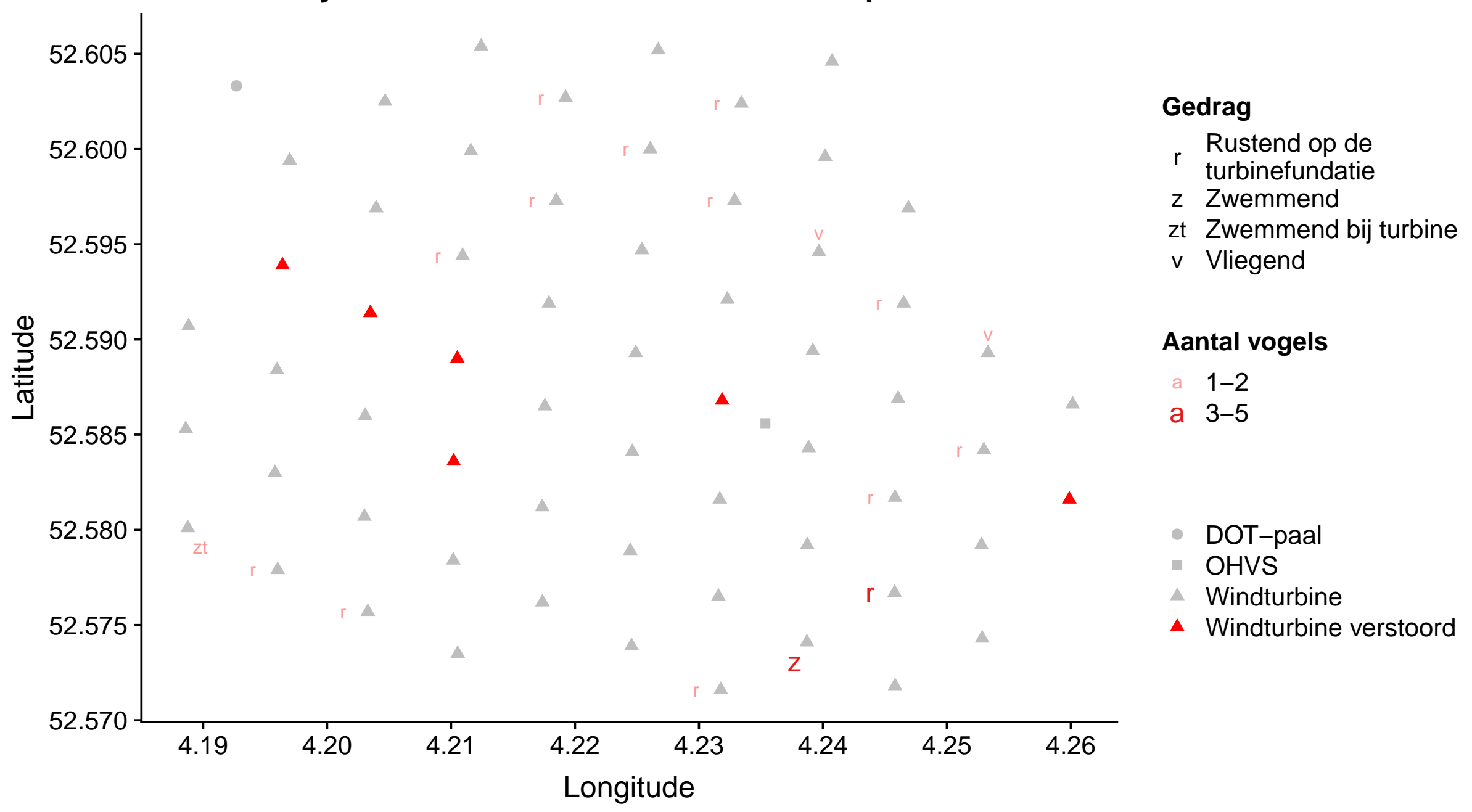


Survey 5: Grote mantelmeeuw in windmolenpark LUD

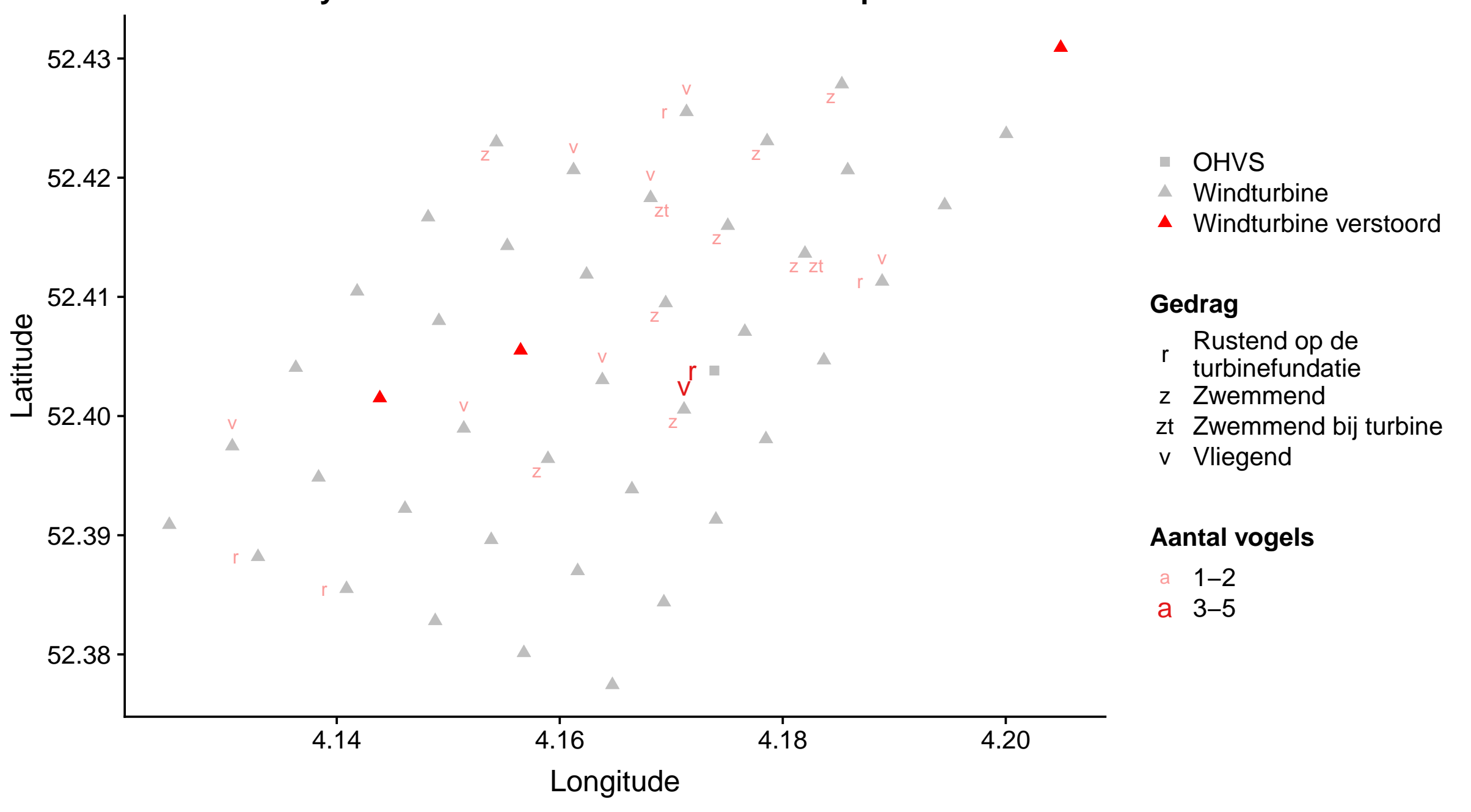


Survey 1: Grote Stern in windmolenpark OWEZ

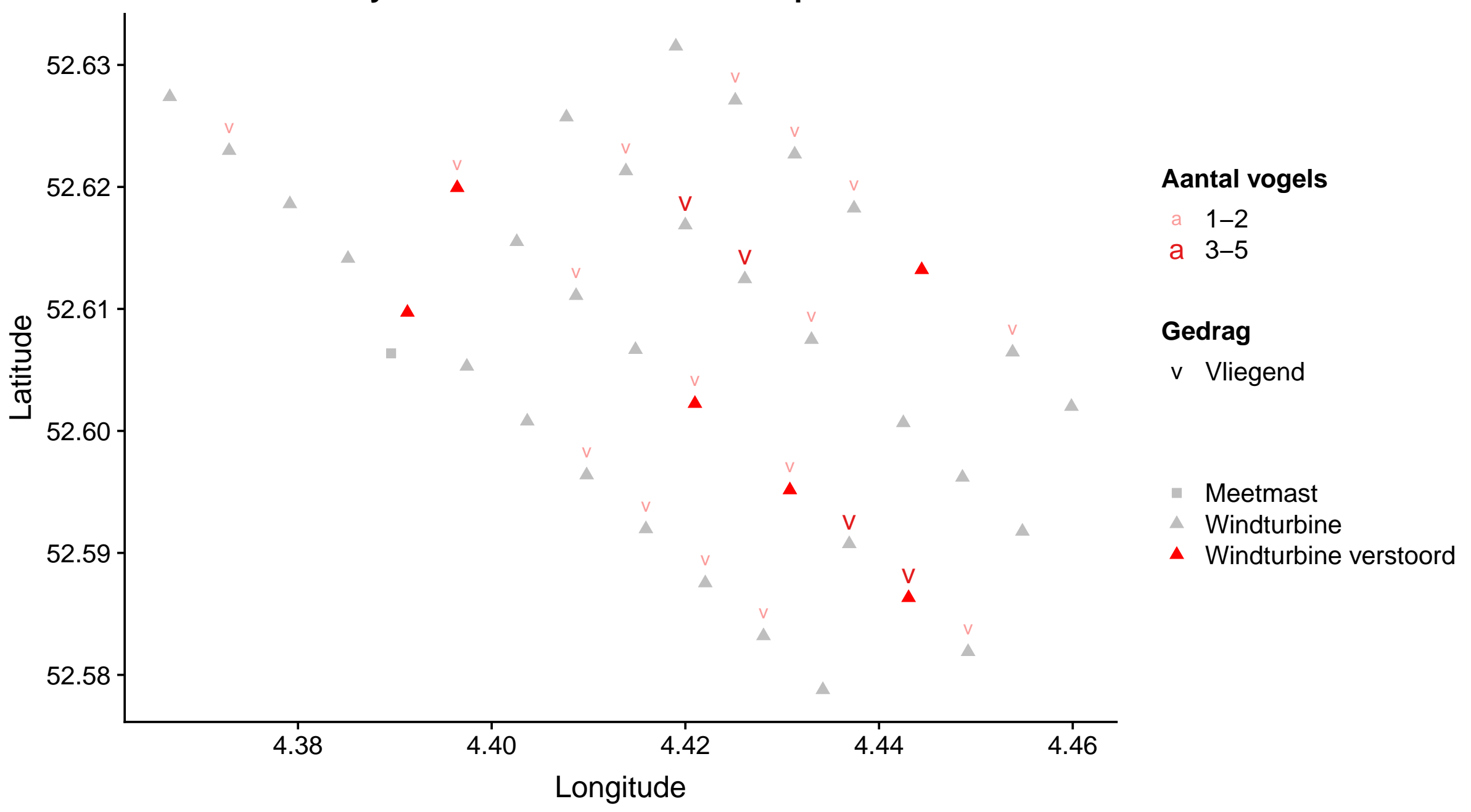


Survey 2: Grote stern in windmolenpark LUD

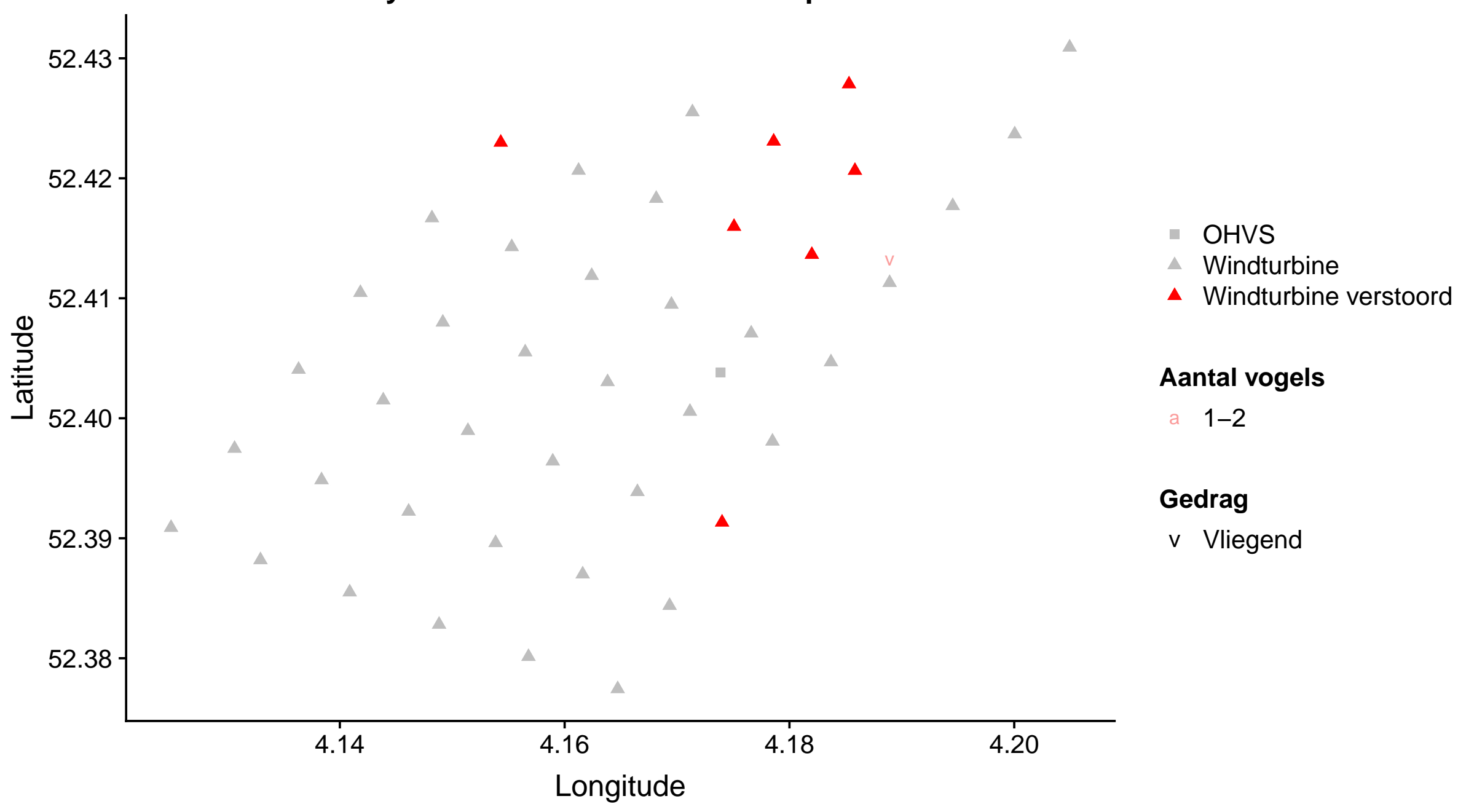




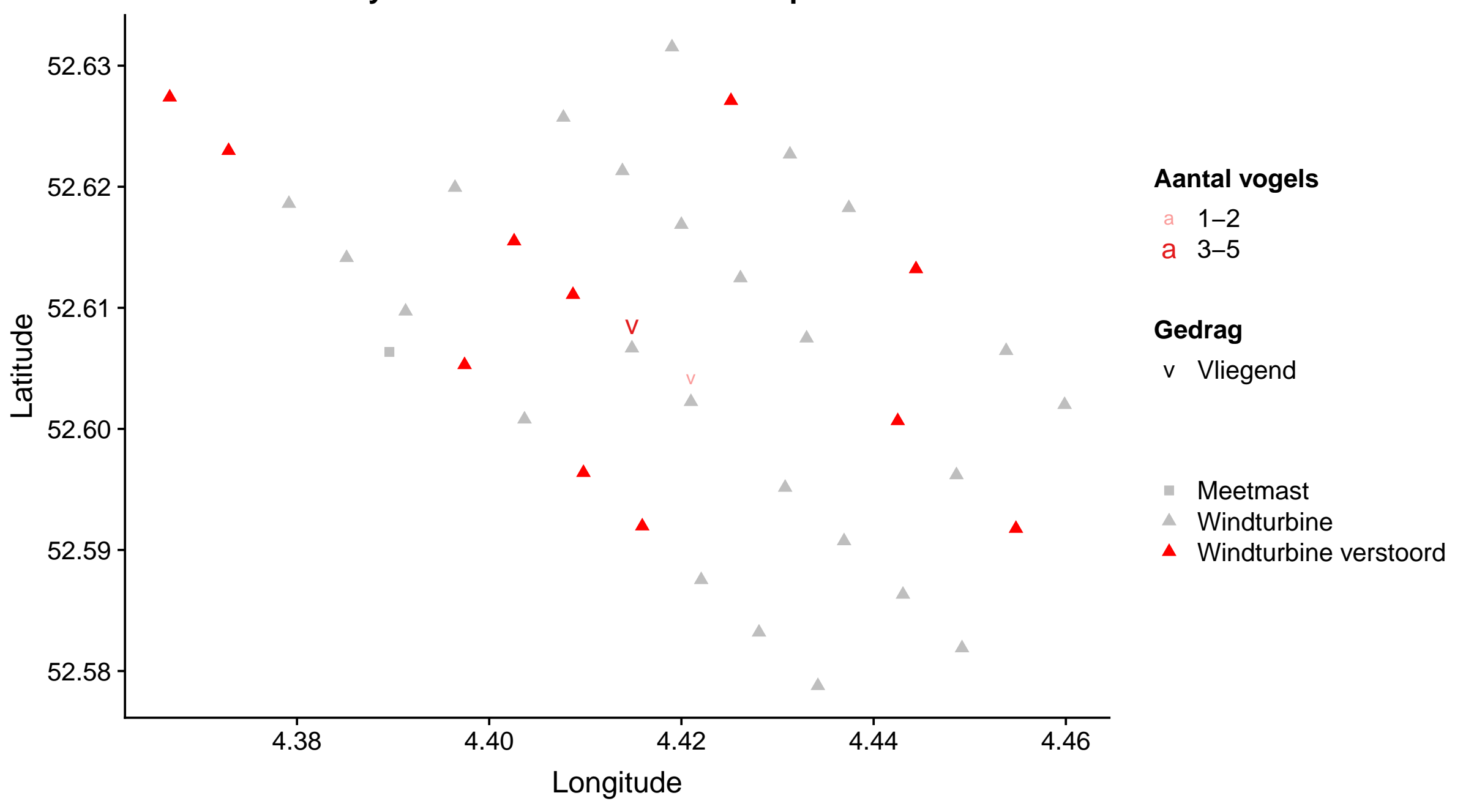




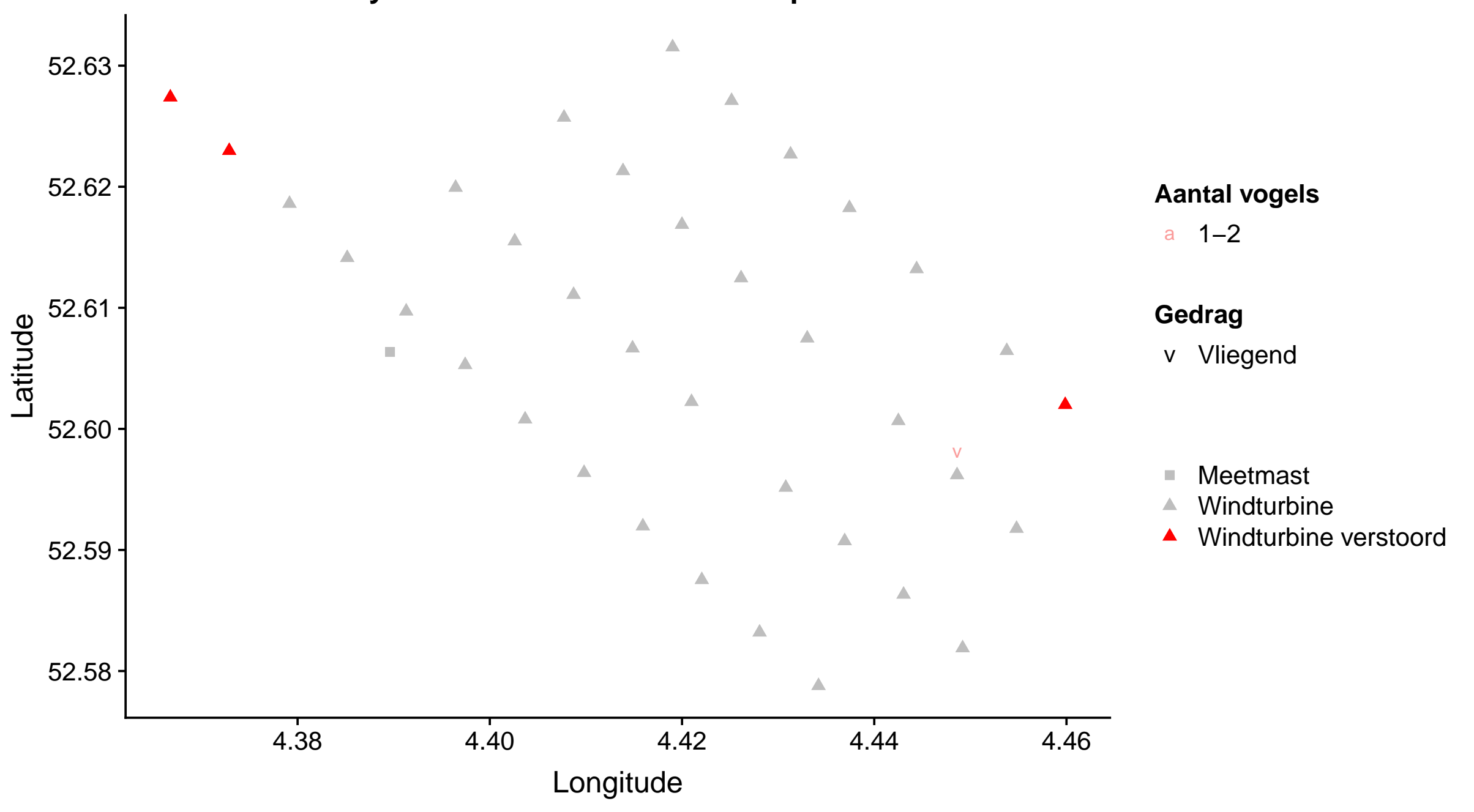


Survey 3: Jan van Gent in windmolenpark LUD

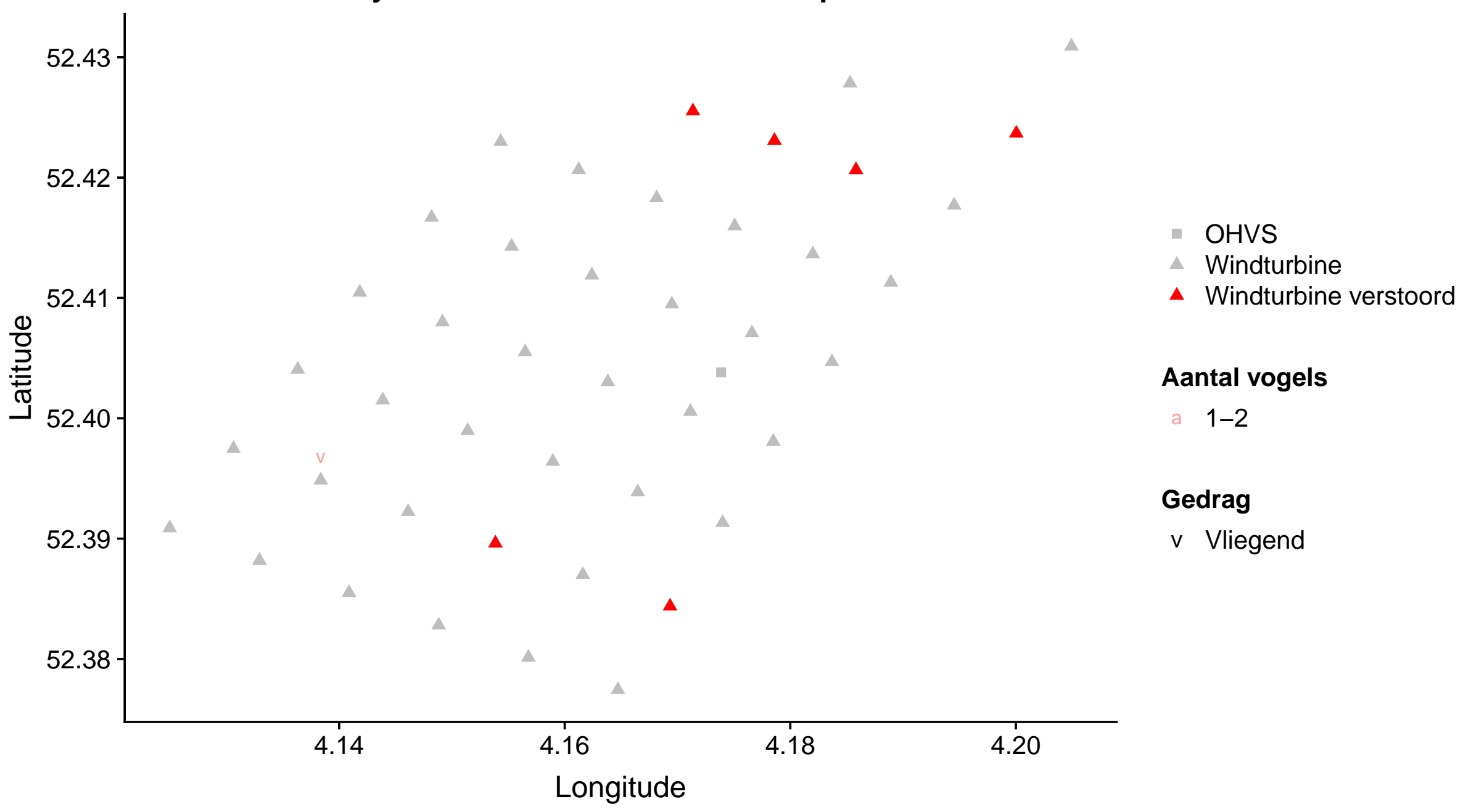


Survey 4: Jan van gent in windmolenpark OWEZ

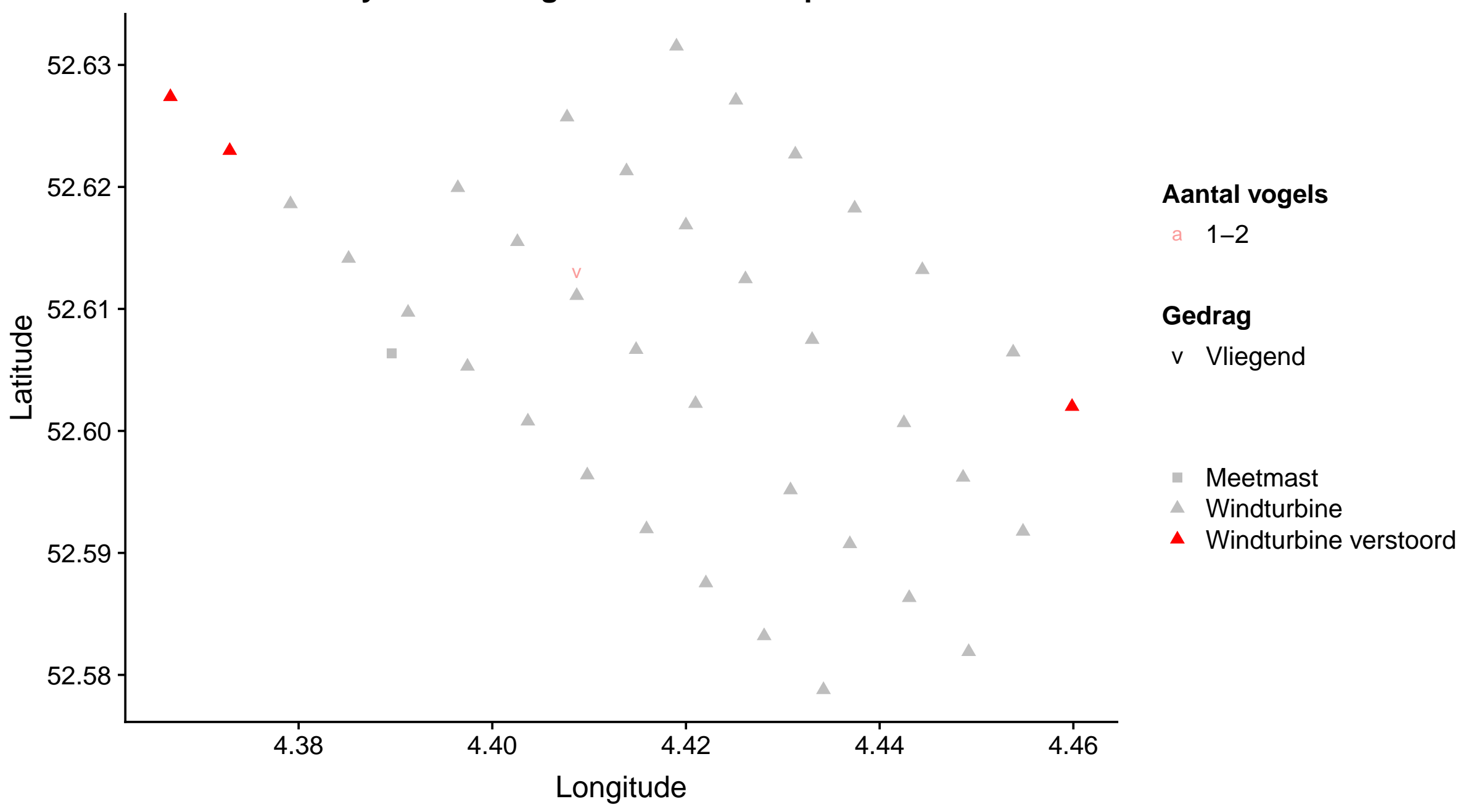


Survey 5: Jan-van-gent in windmolenpark OWEZ

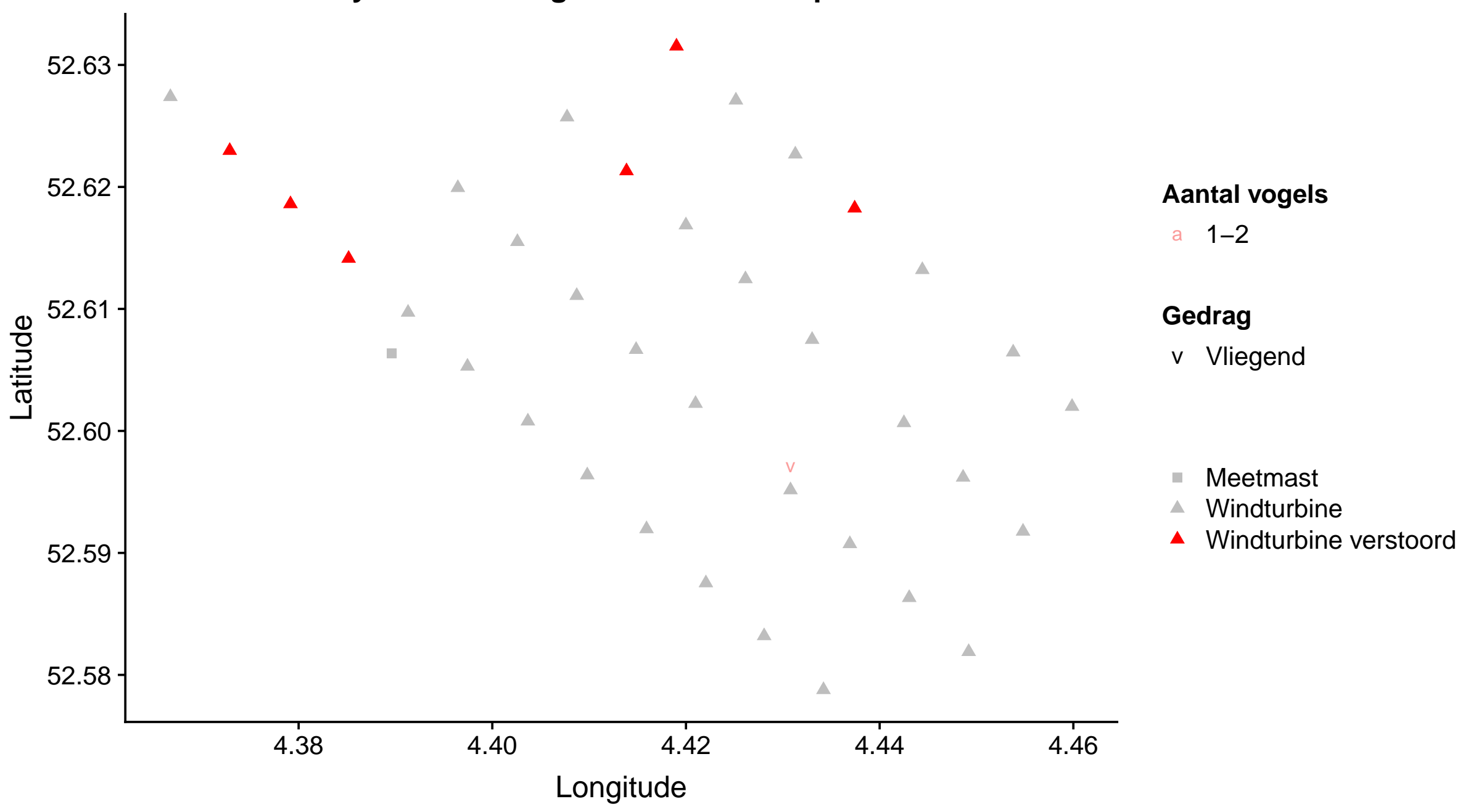




\section{Survey 3: Kievit in windmolenpark LUD}

을

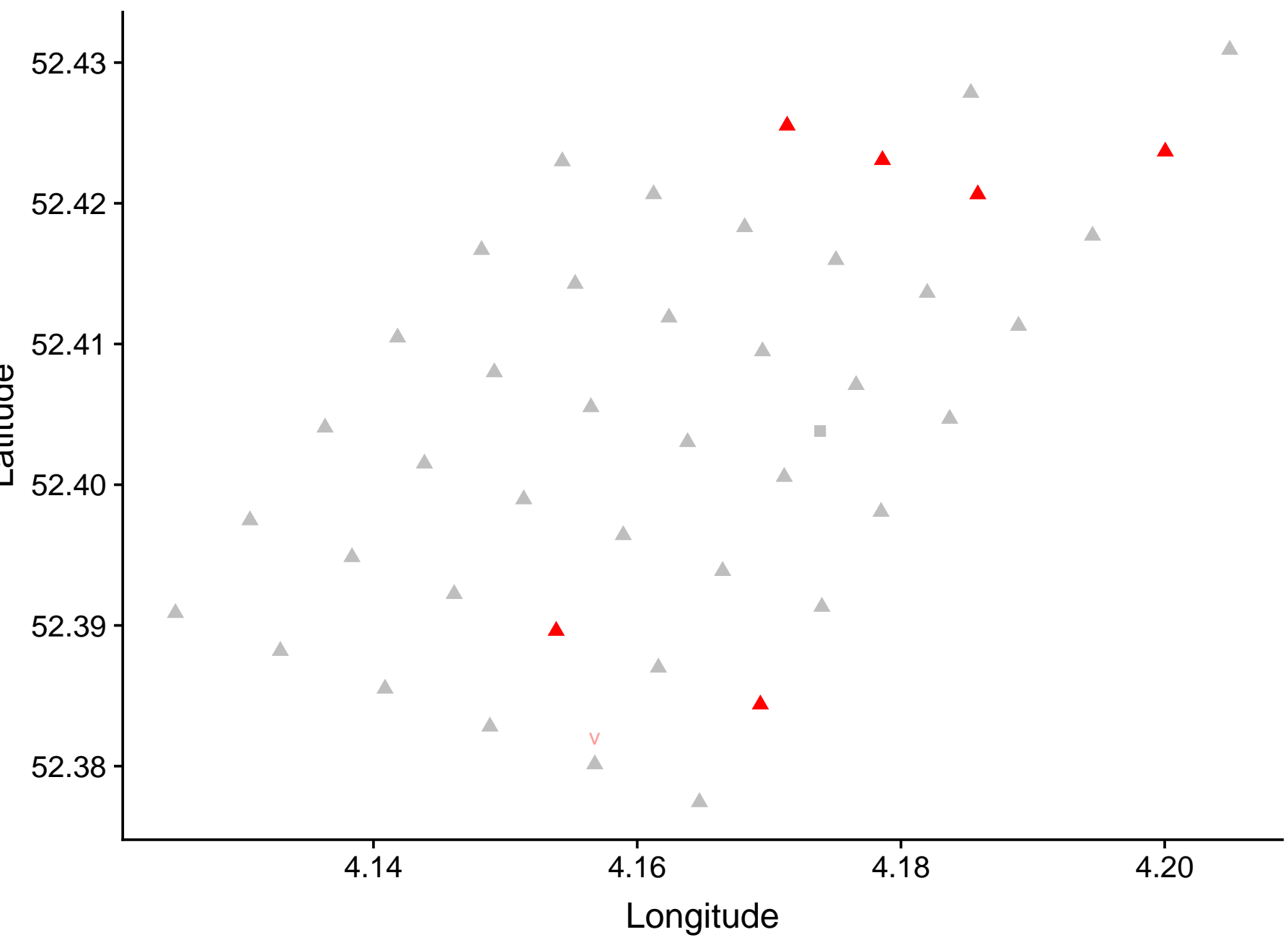

- OHVS

Windturbine

- Windturbine verstoord

Aantal vogels

a 1-2

Gedrag

v Vliegend 


\section{Survey 1: Kleine mantelmeeuw in windmolenpark OWEZ}

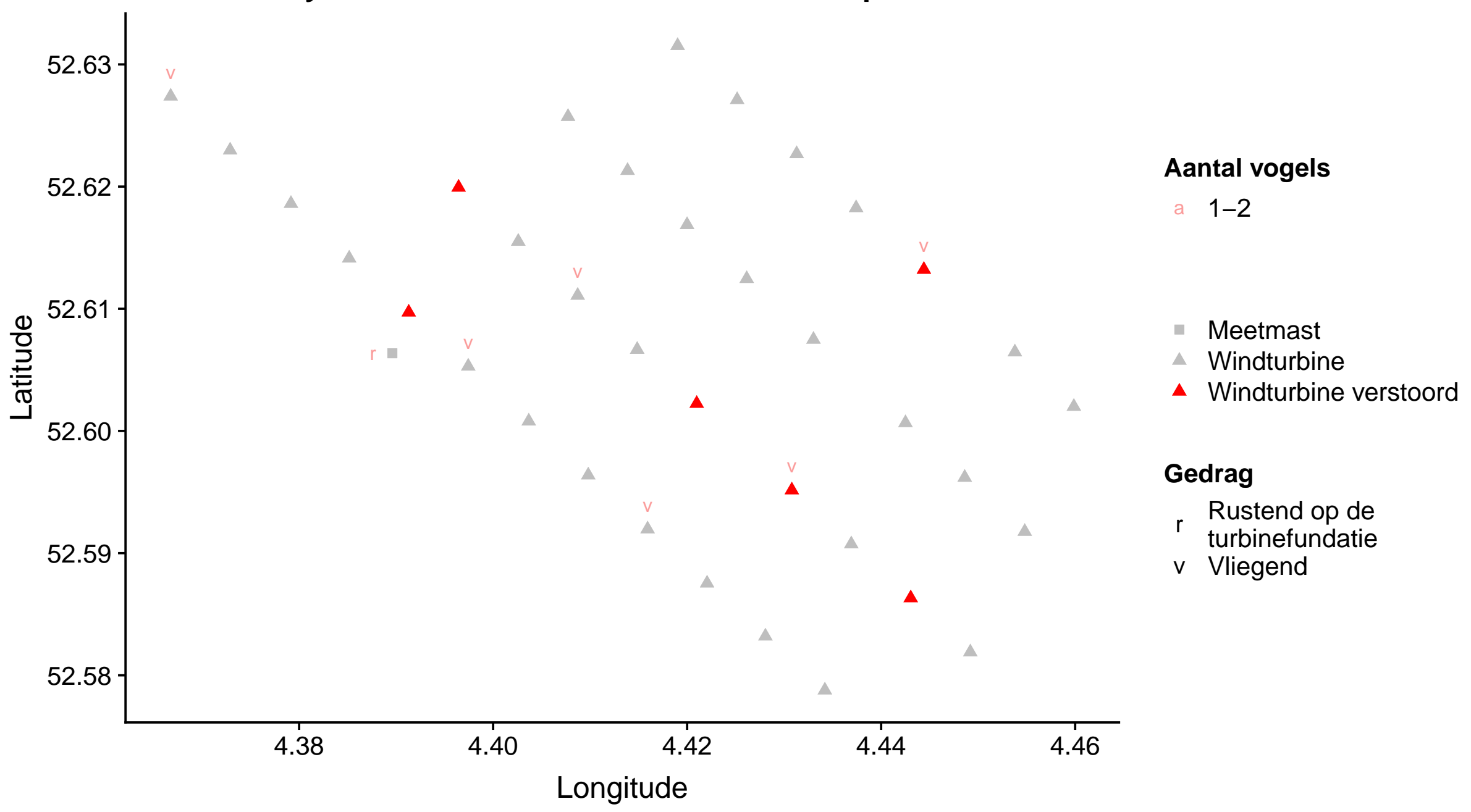




\section{Survey 1: Kleine mantelmeeuw in windmolenpark LUD}

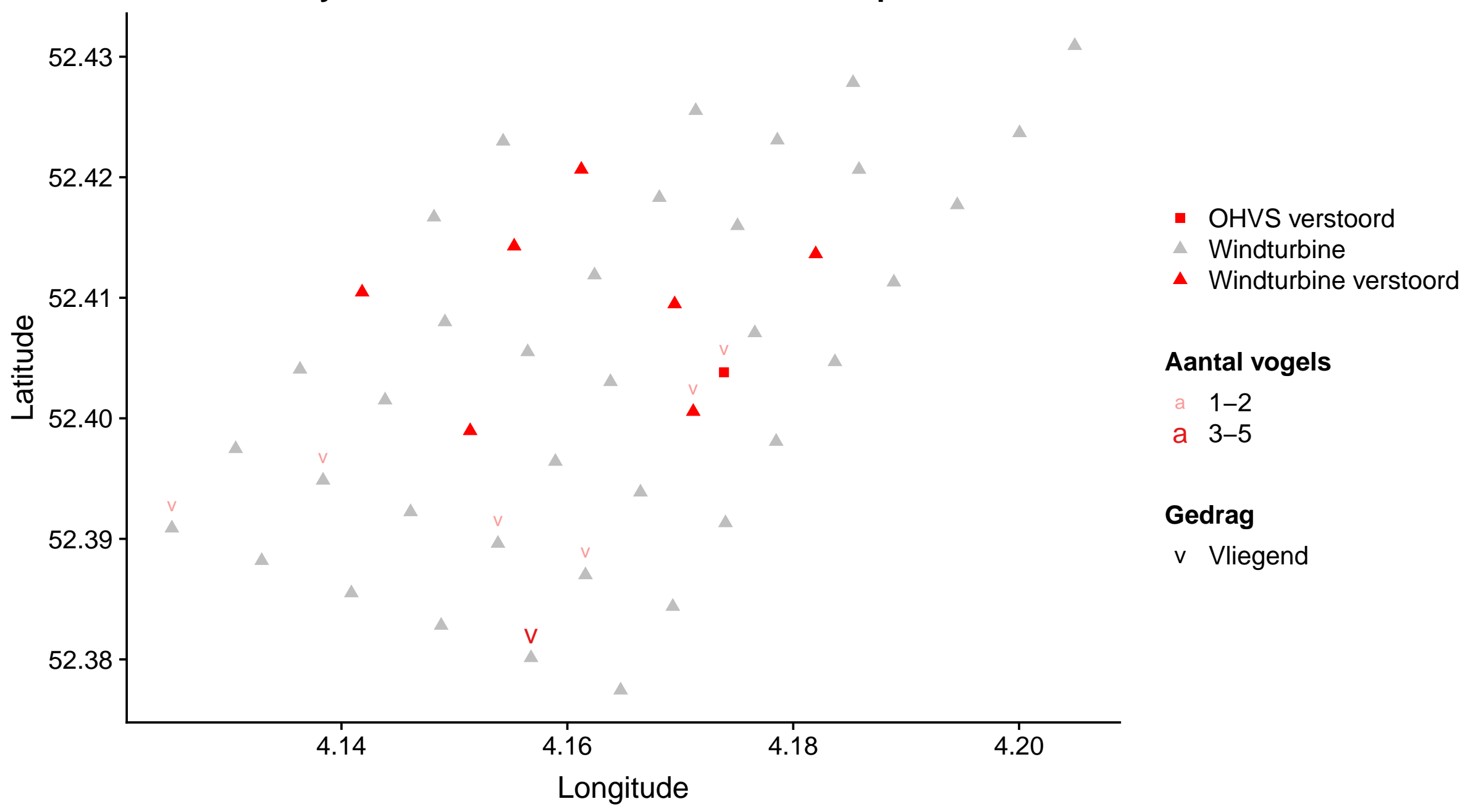




\section{Survey 2: Kleine mantelmeeuw in windmolenpark OWEZ}

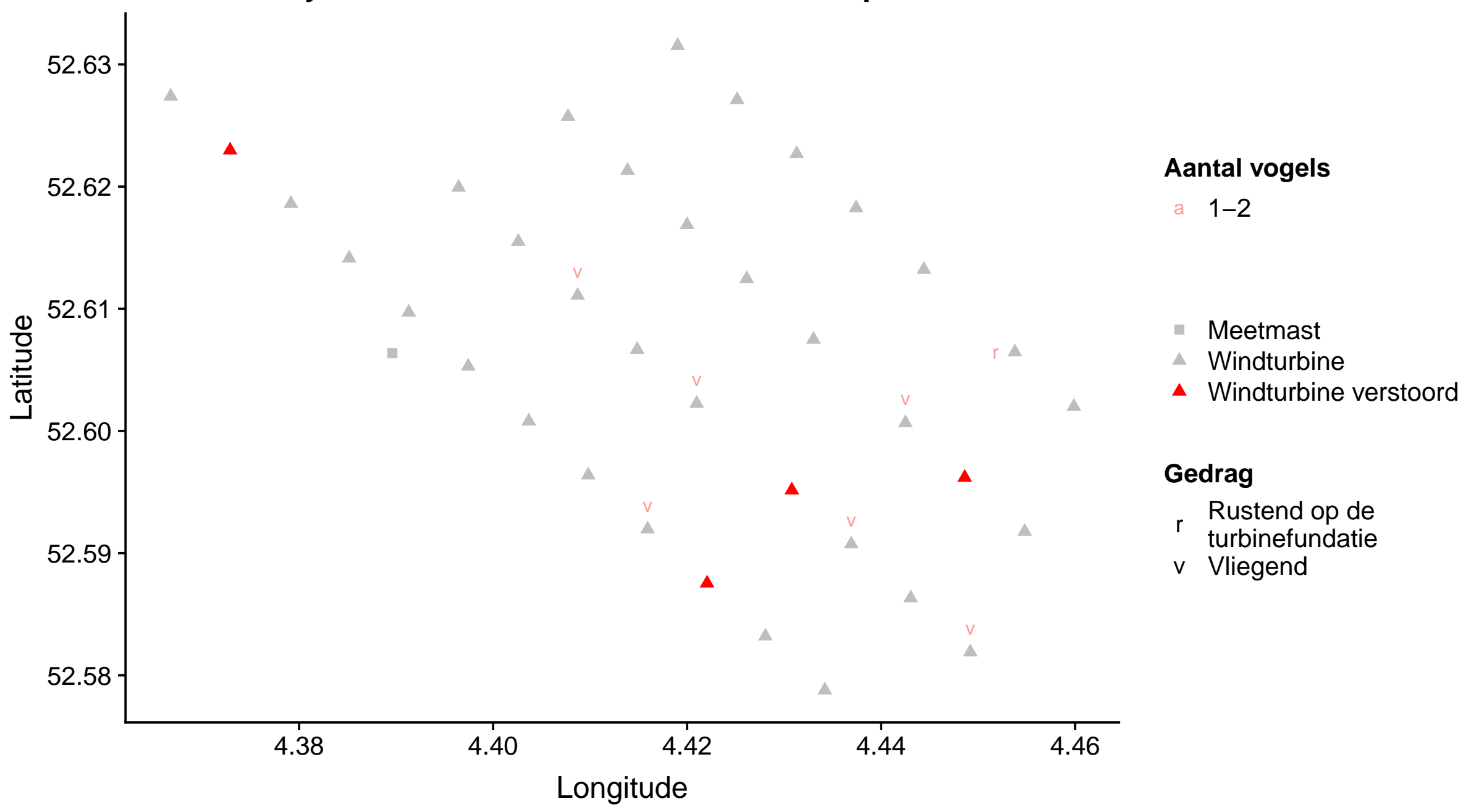


Survey 2: Kleine mantelmeeuw in windmolenpark PAWP

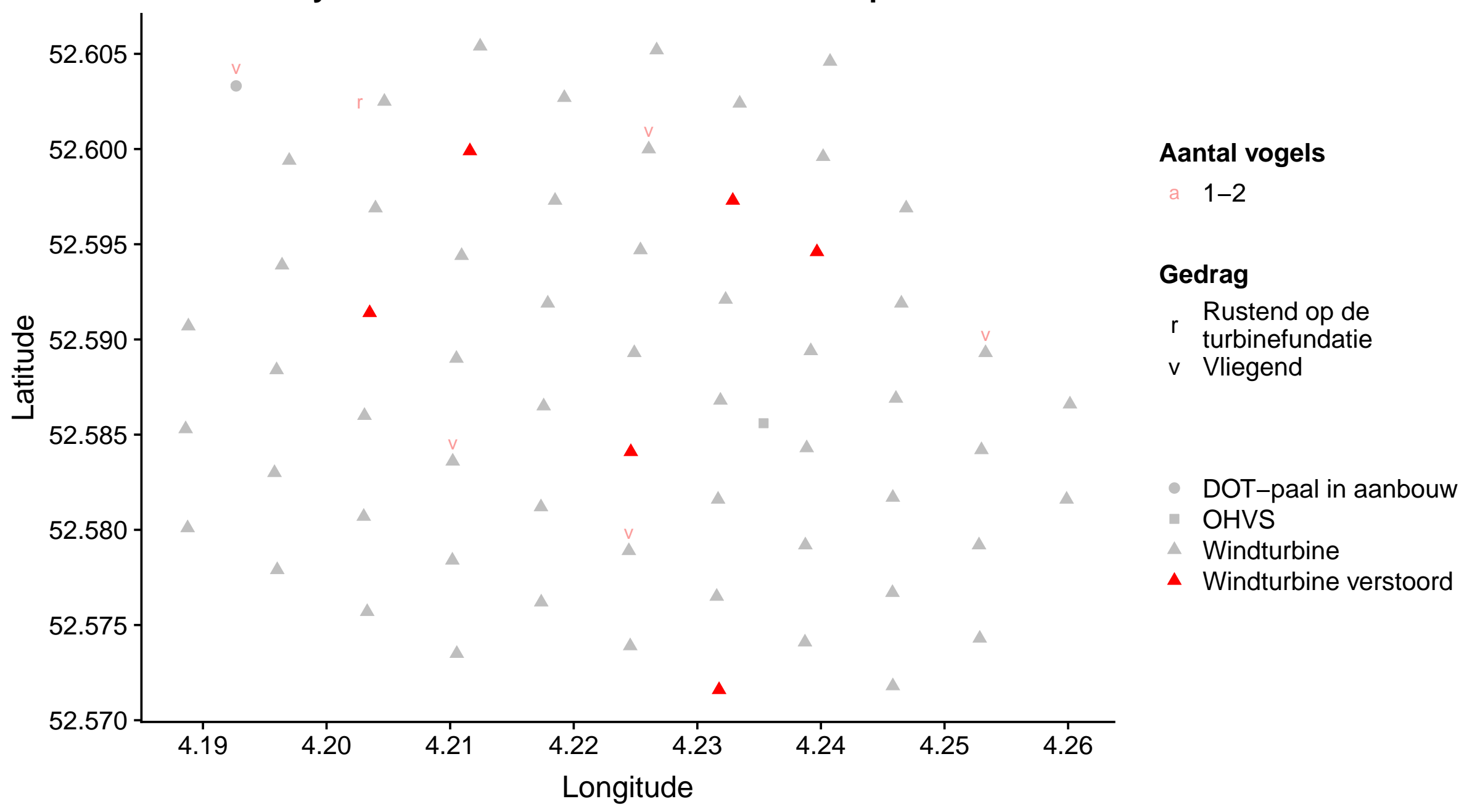


Survey 2: Kleine mantelmeeuw in windmolenpark LUD

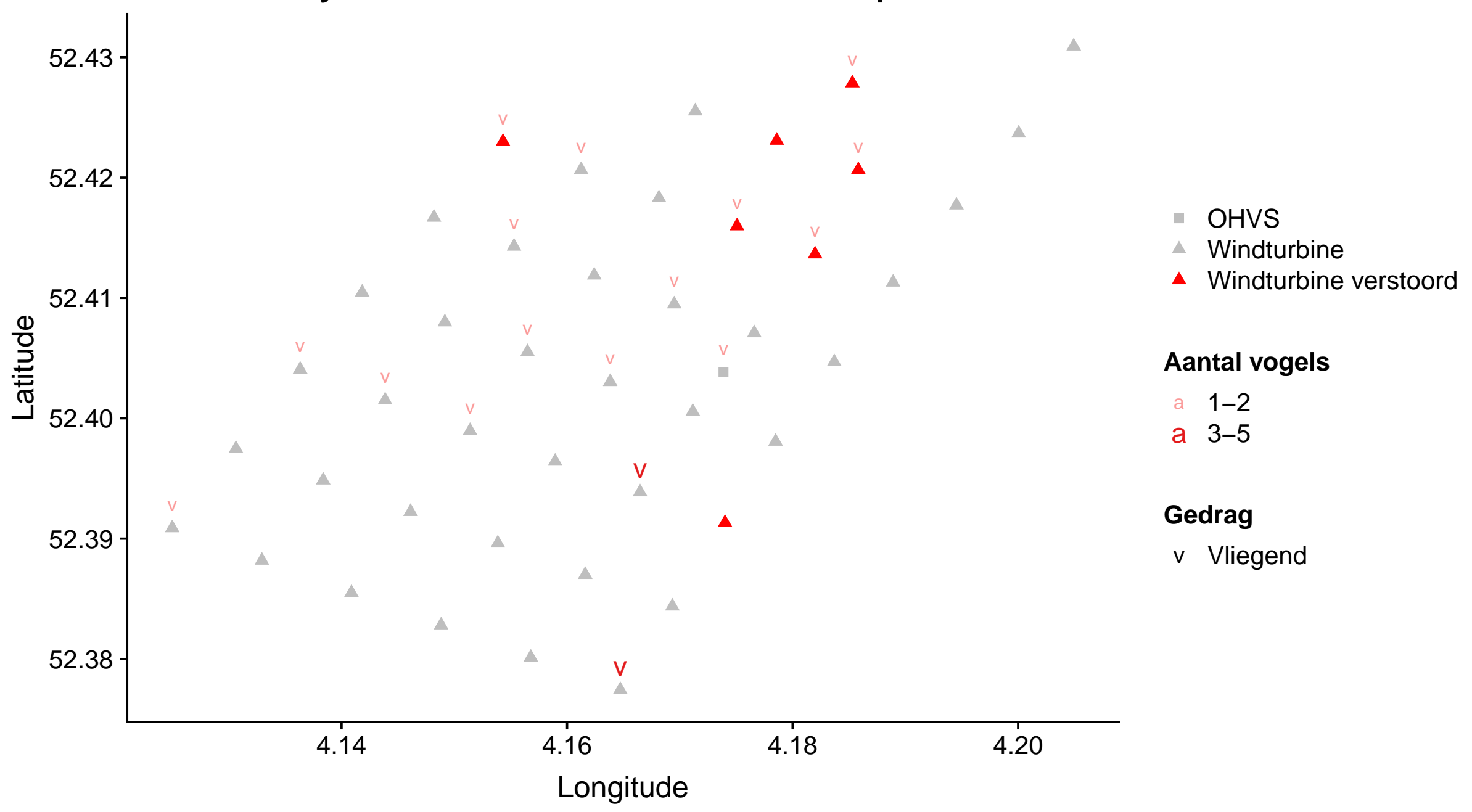




\section{Survey 3: Kleine mantelmeeuw in windmolenpark OWEZ}

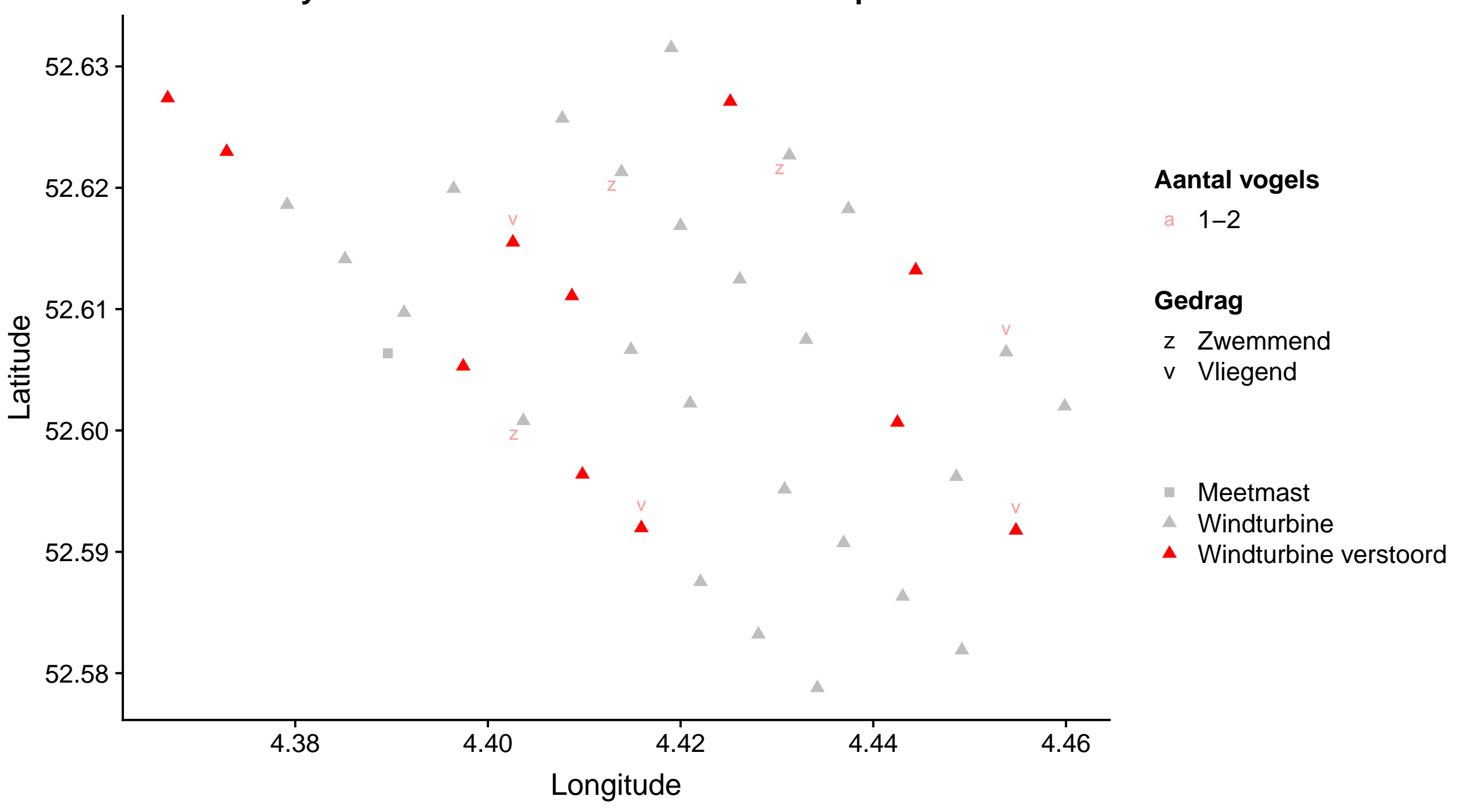


Survey 3: Kleine mantelmeeuw in windmolenpark LUD

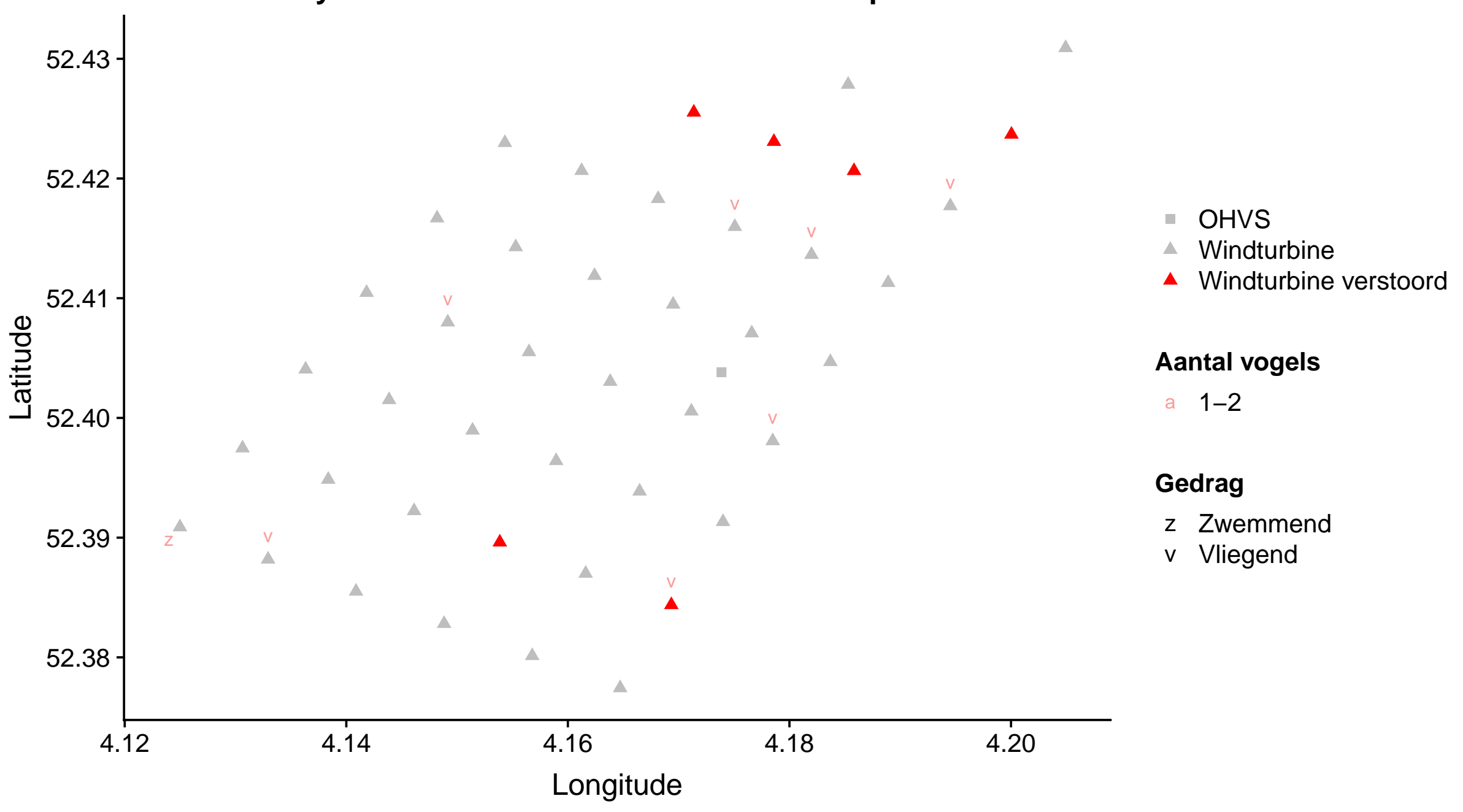




\section{Survey 4: Kleine mantelmeeuw in windmolenpark OWEZ}

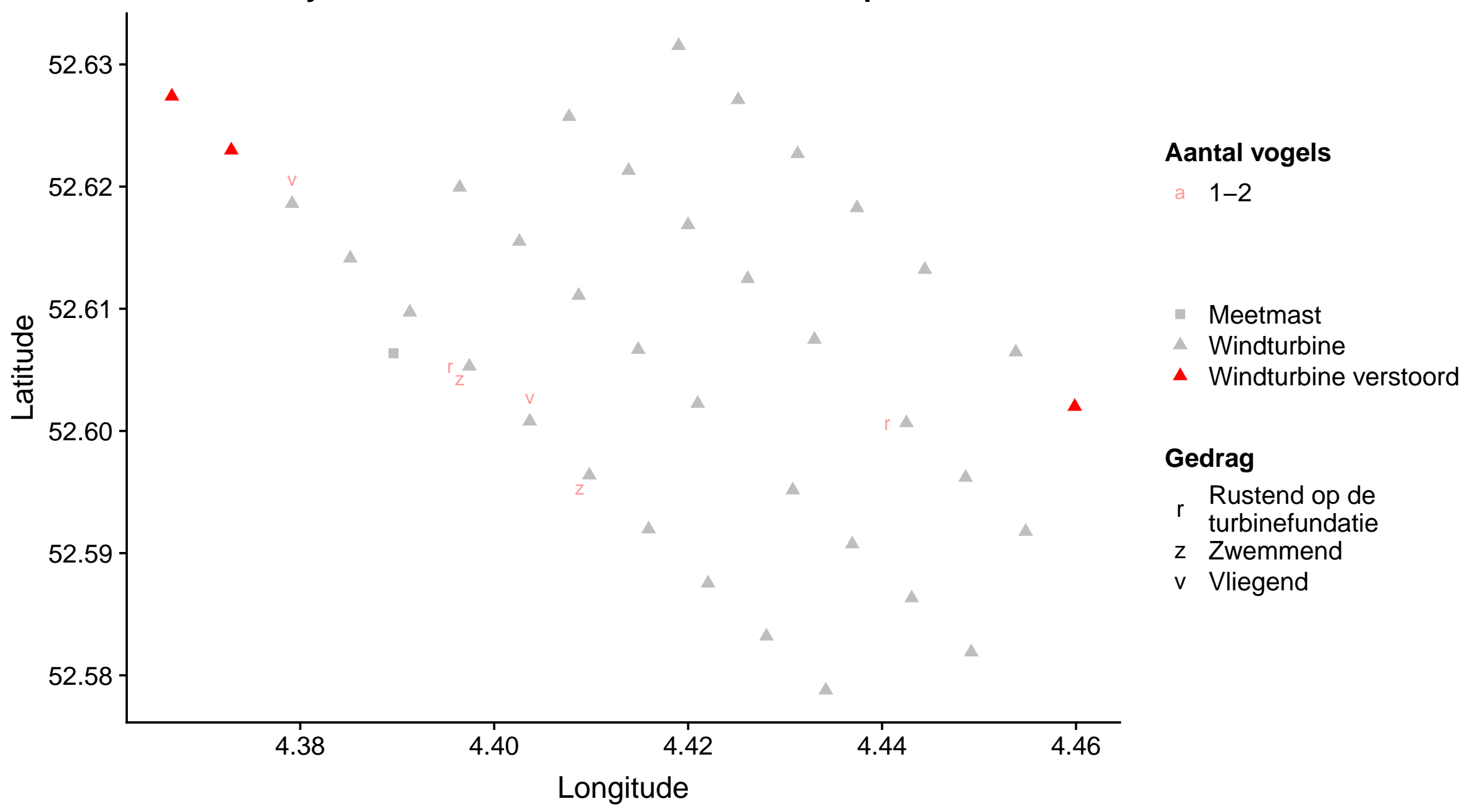


Survey 4: Kleine mantelmeeuw in windmolenpark PAWP

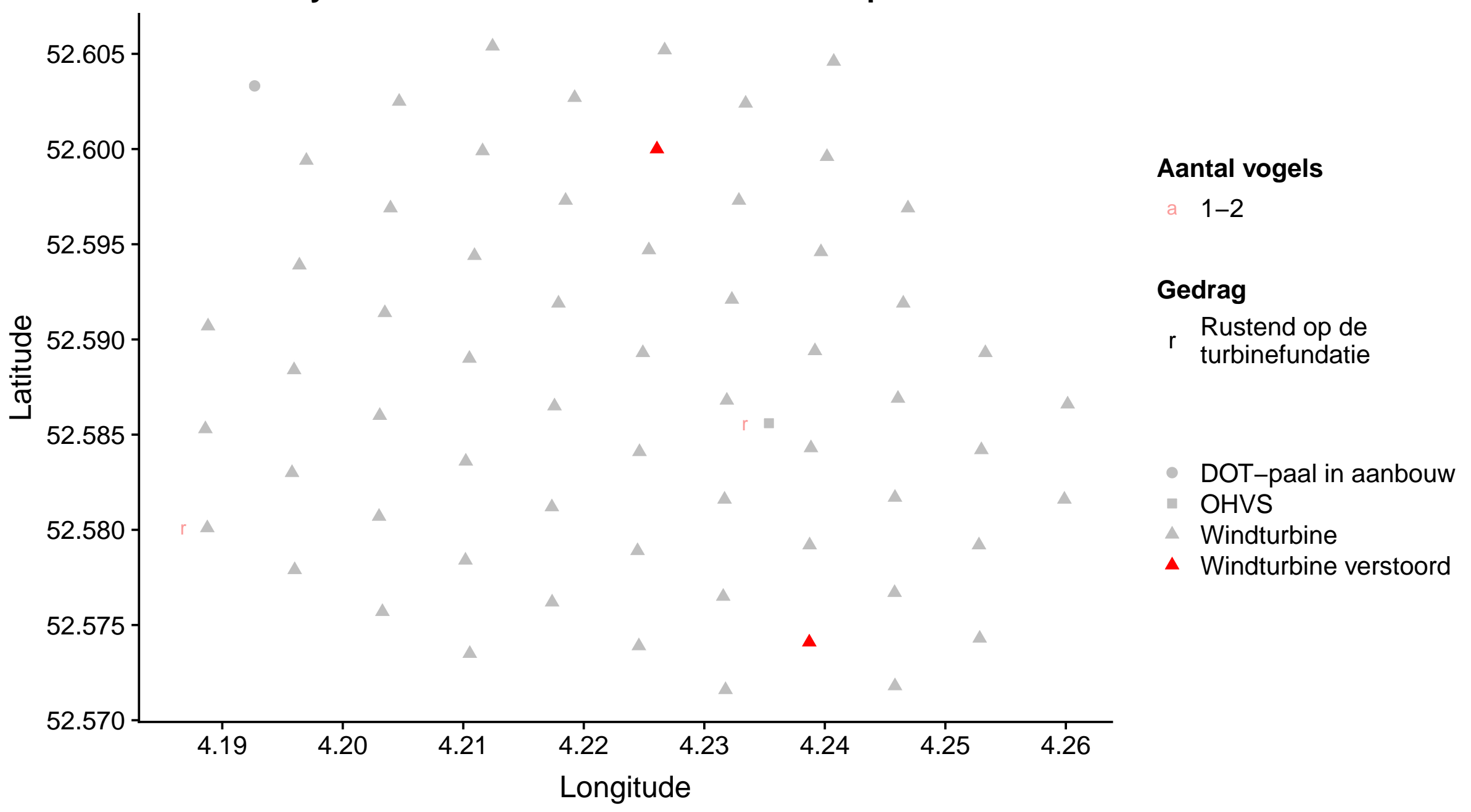




\section{Survey 5: Kleine mantelmeeuw in windmolenpark OWEZ}

$\frac{0}{0}$

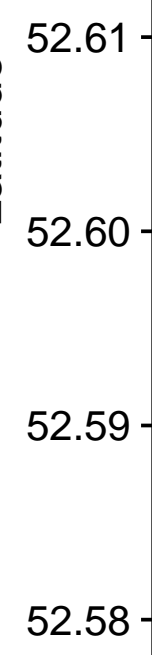

$\Delta$ v
$\Delta$

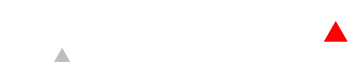

$\Delta$

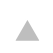

$\triangle$

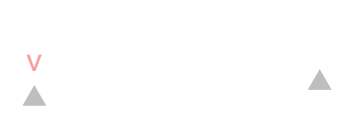

\section{Aantal vogels}

a 1-2

\section{Gedrag}

z Zwemmend

$\checkmark$ Vliegend

- Meetmast

$\Delta$ Windturbine

- Windturbine verstoord 
Survey 5: Kleine mantelmeeuw in windmolenpark PAWP

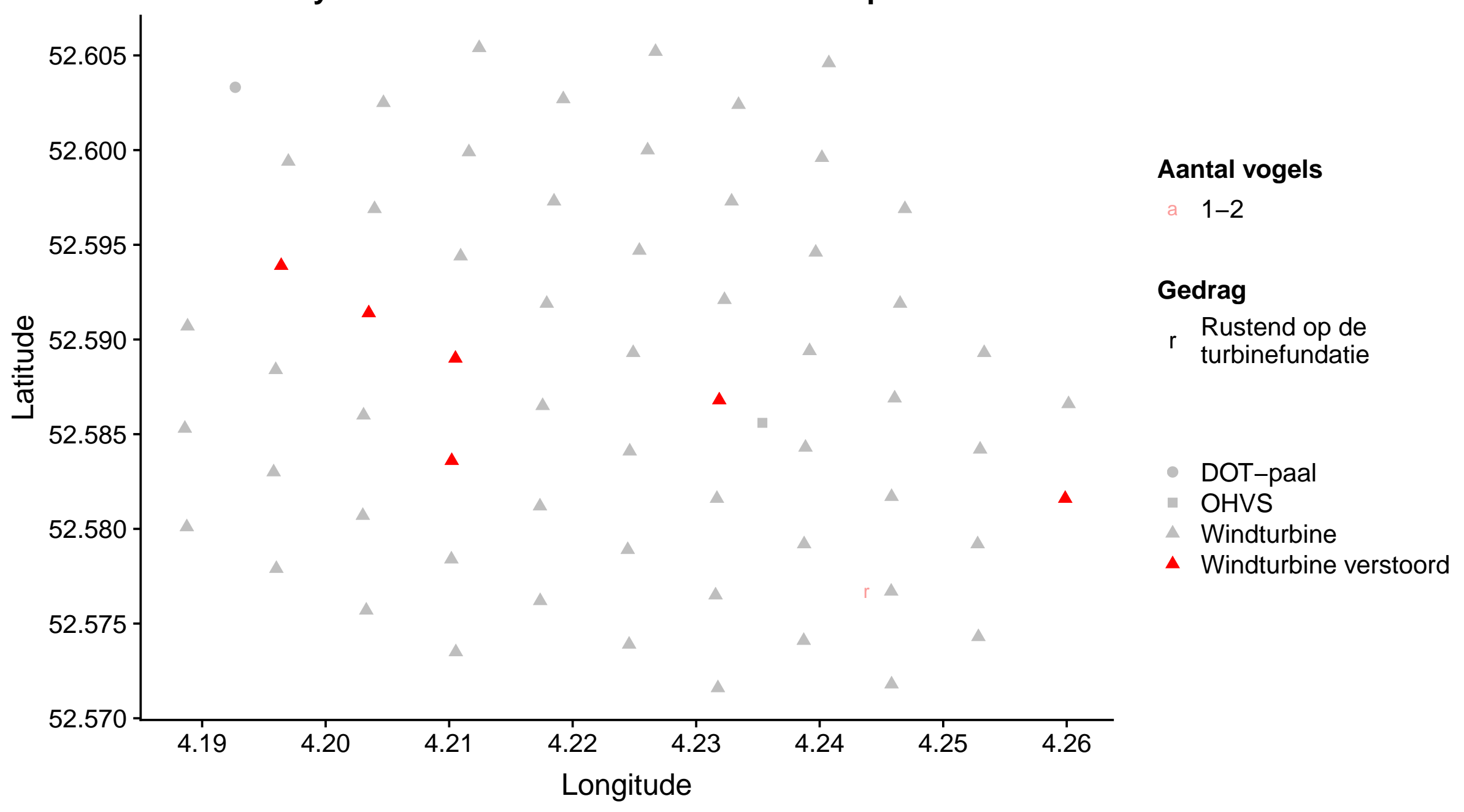


Survey 2: Kokmeeuw in windmolenpark LUD

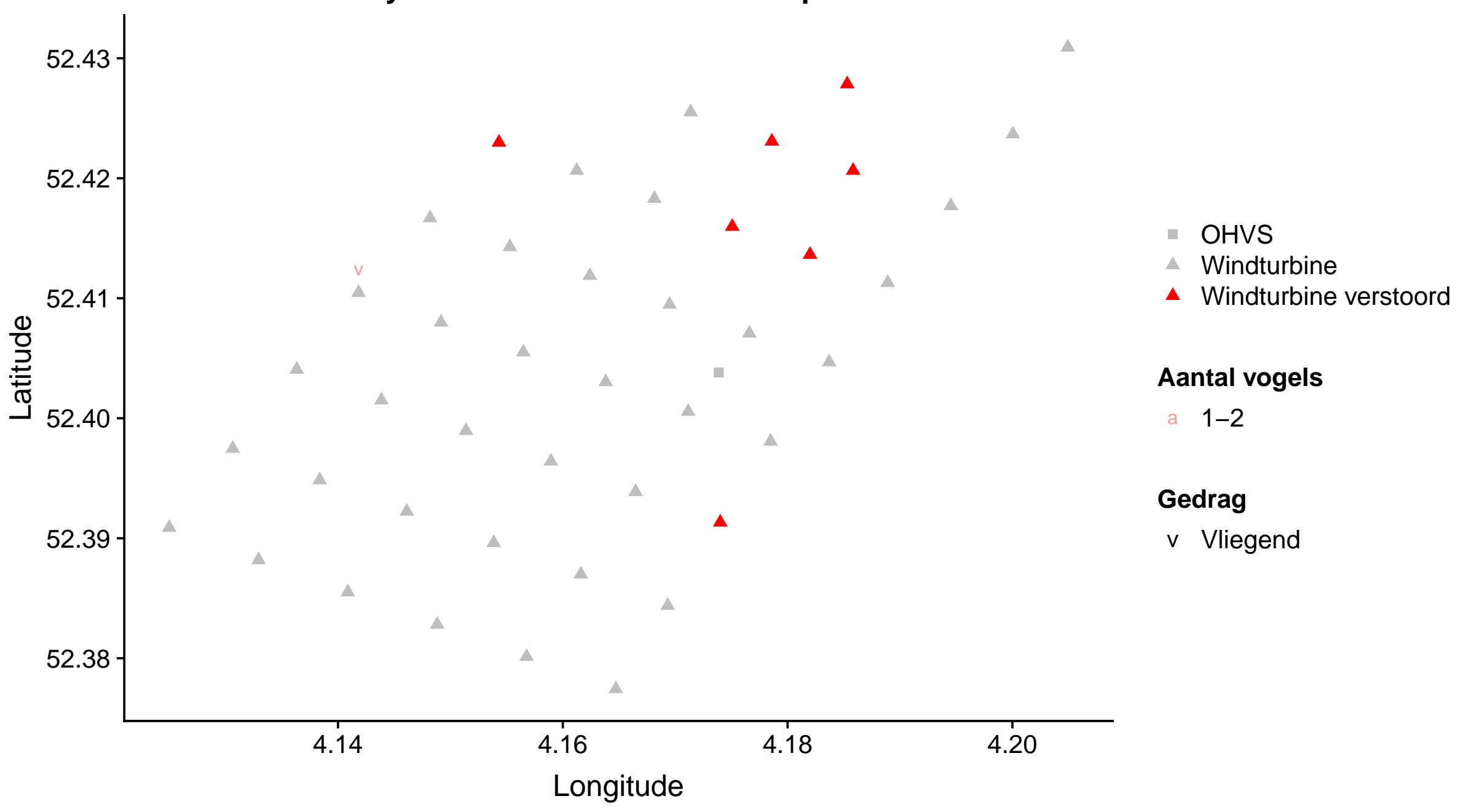


Survey 3: Kokmeeuw in windmolenpark OWEZ

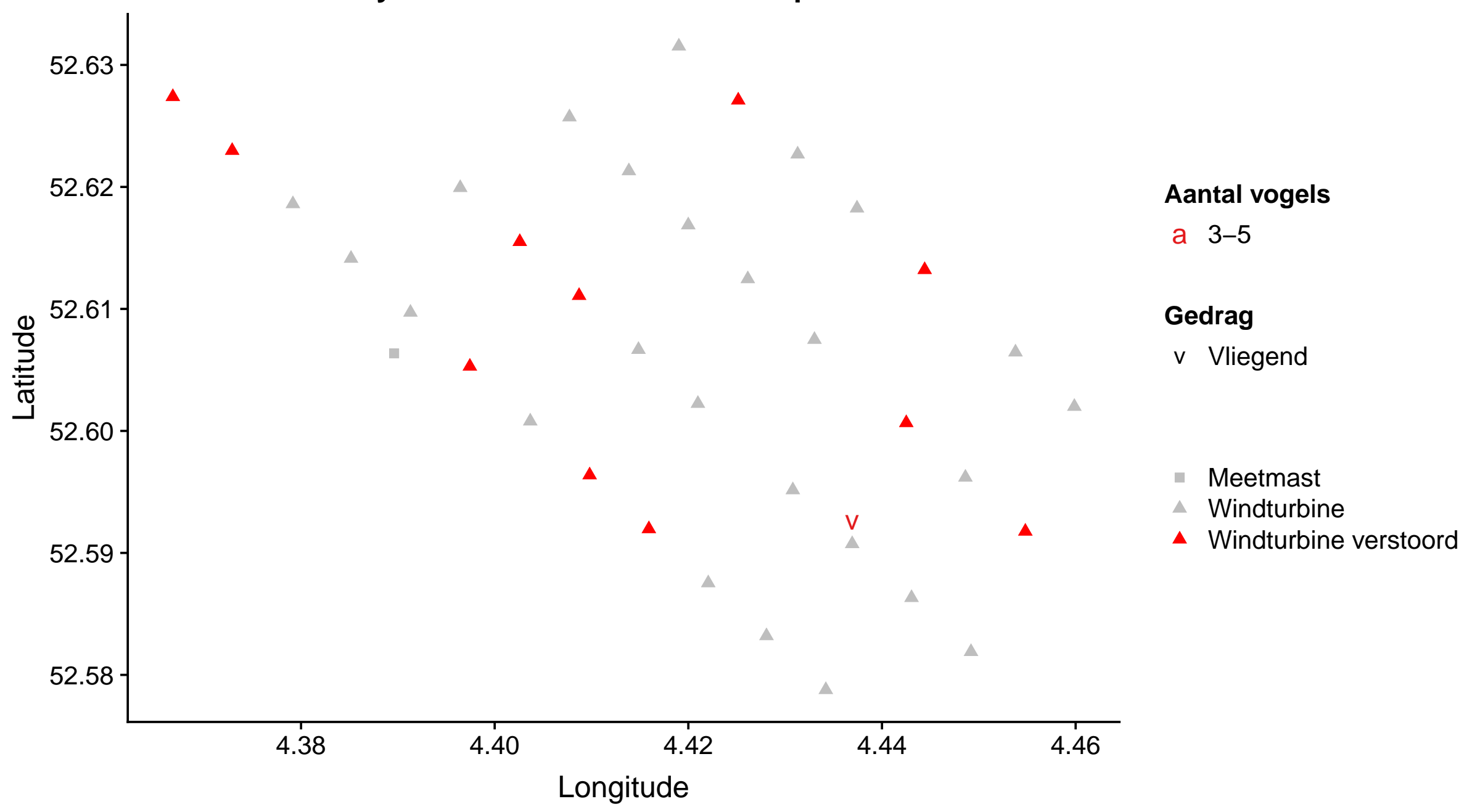




\section{Survey 3: Kokmeeuw in windmolenpark PAWP}

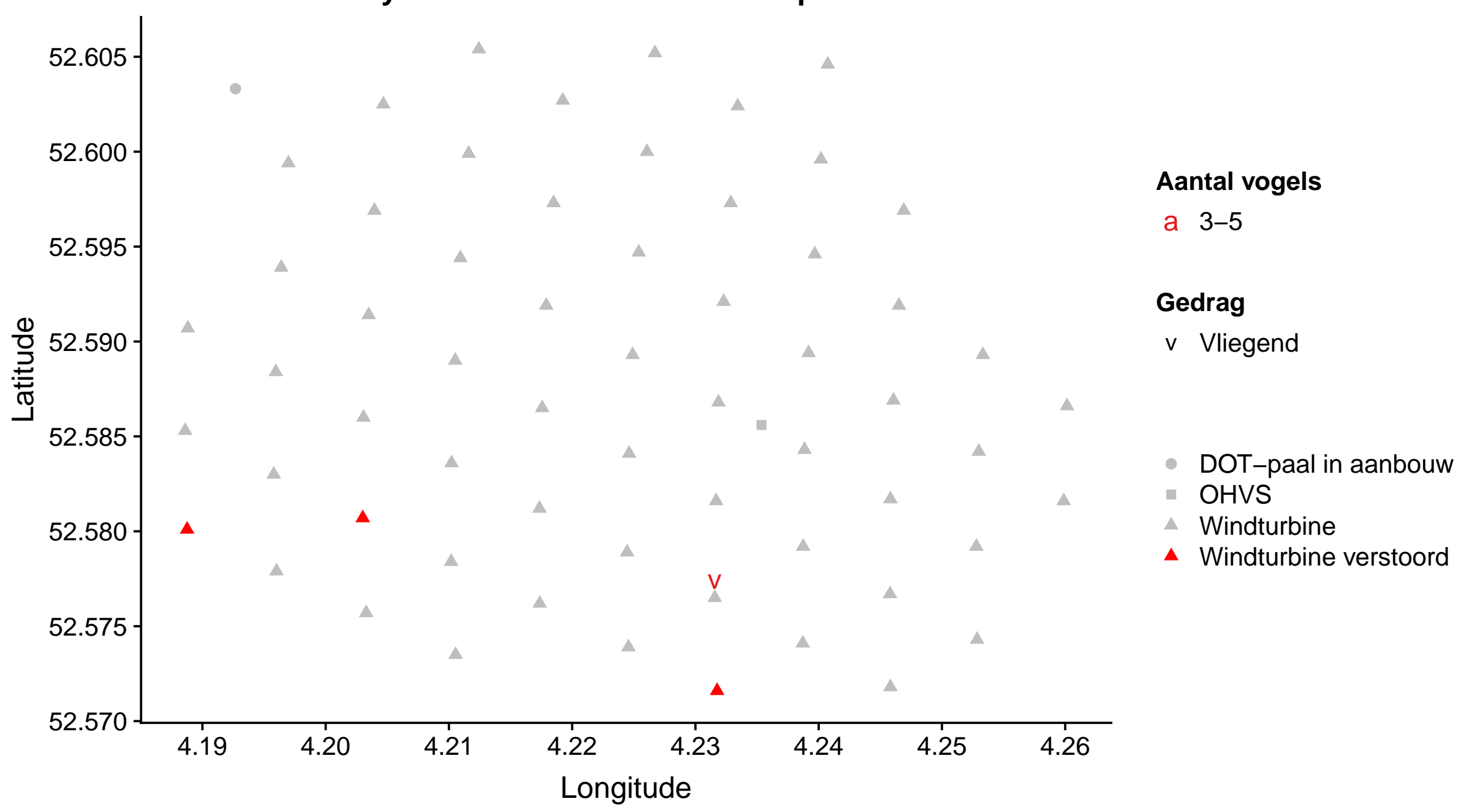


Survey 3: Kokmeeuw in windmolenpark LUD

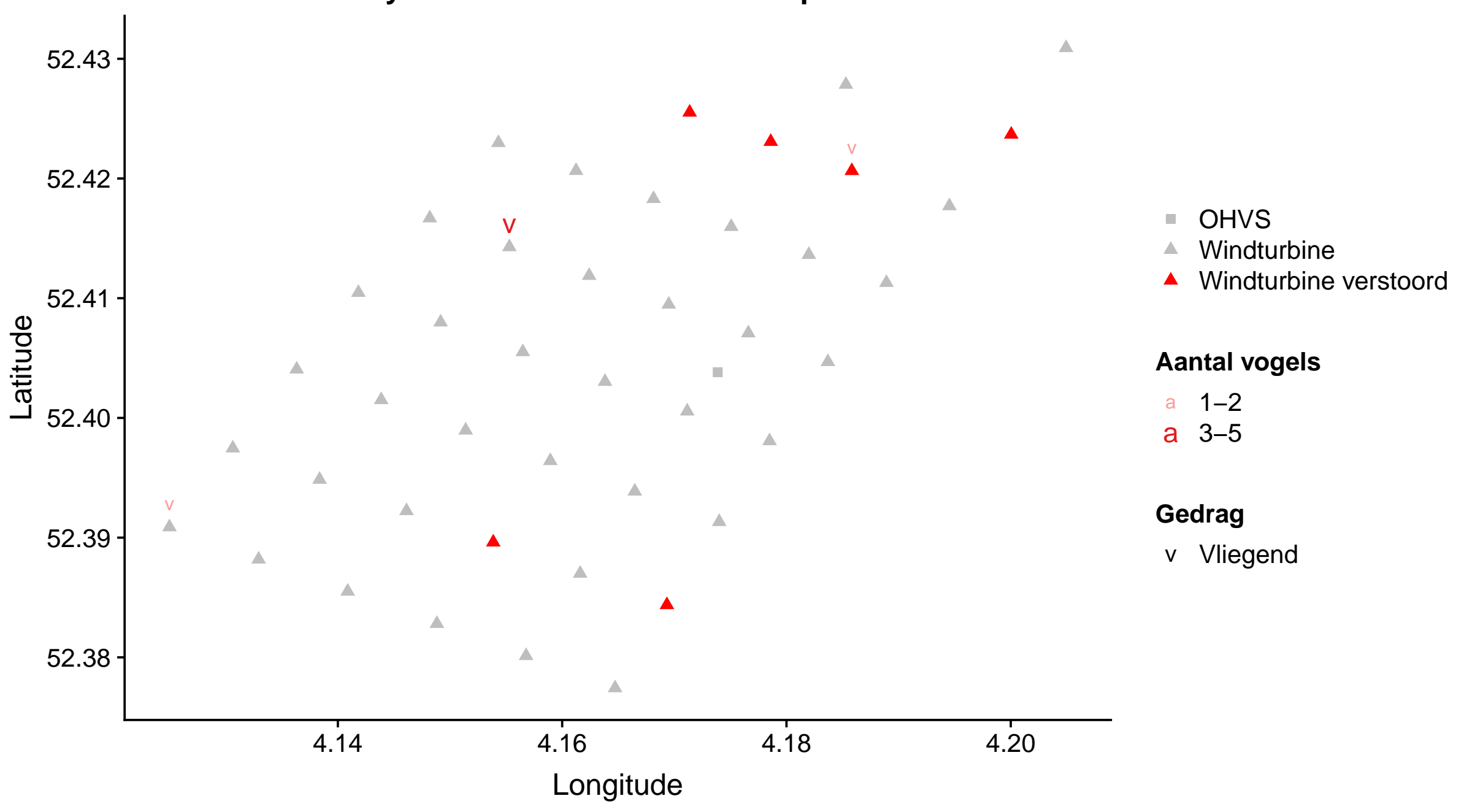


Survey 5: Kokmeeuw in windmolenpark OWEZ

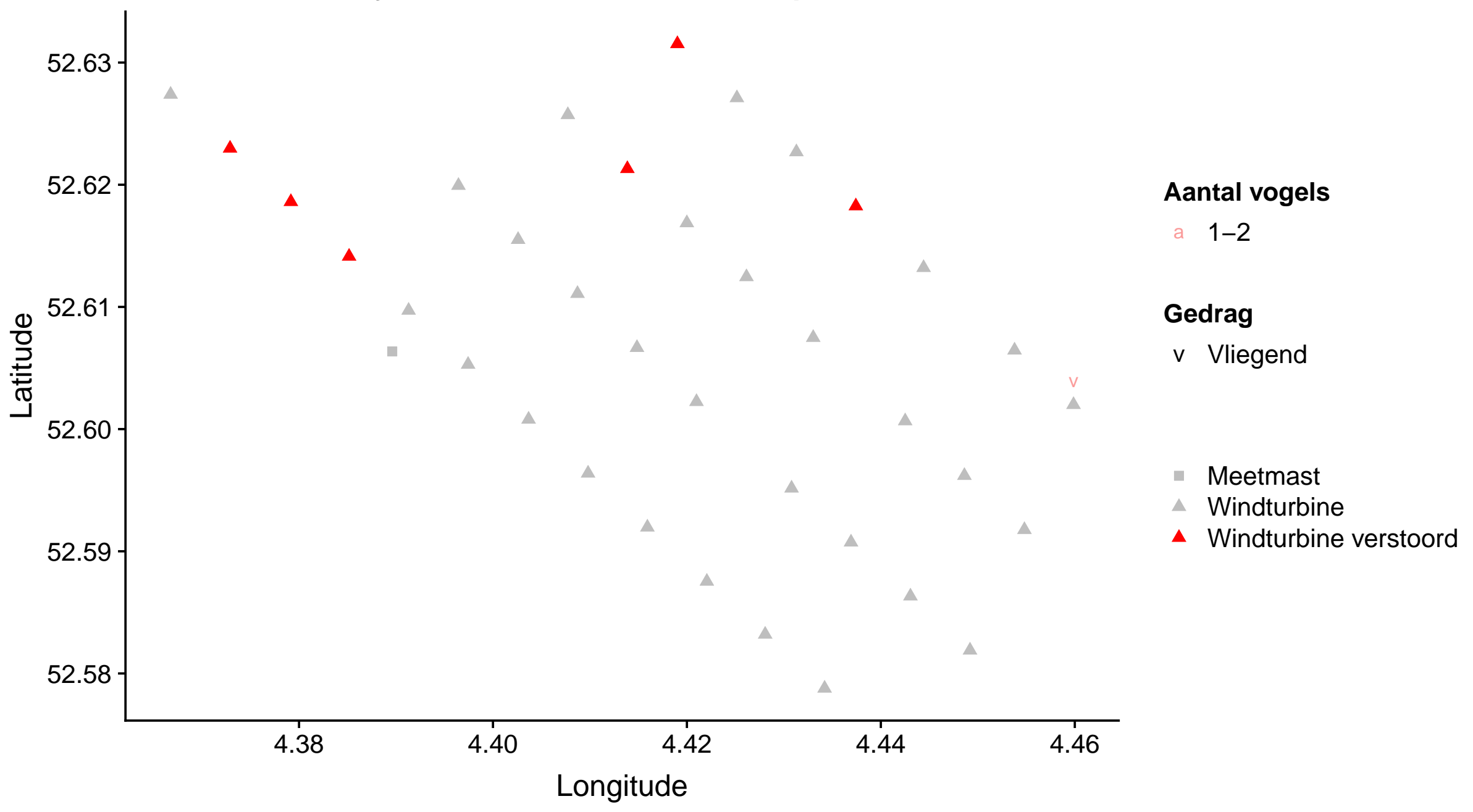


Survey 5: Kokmeeuw in windmolenpark LUD

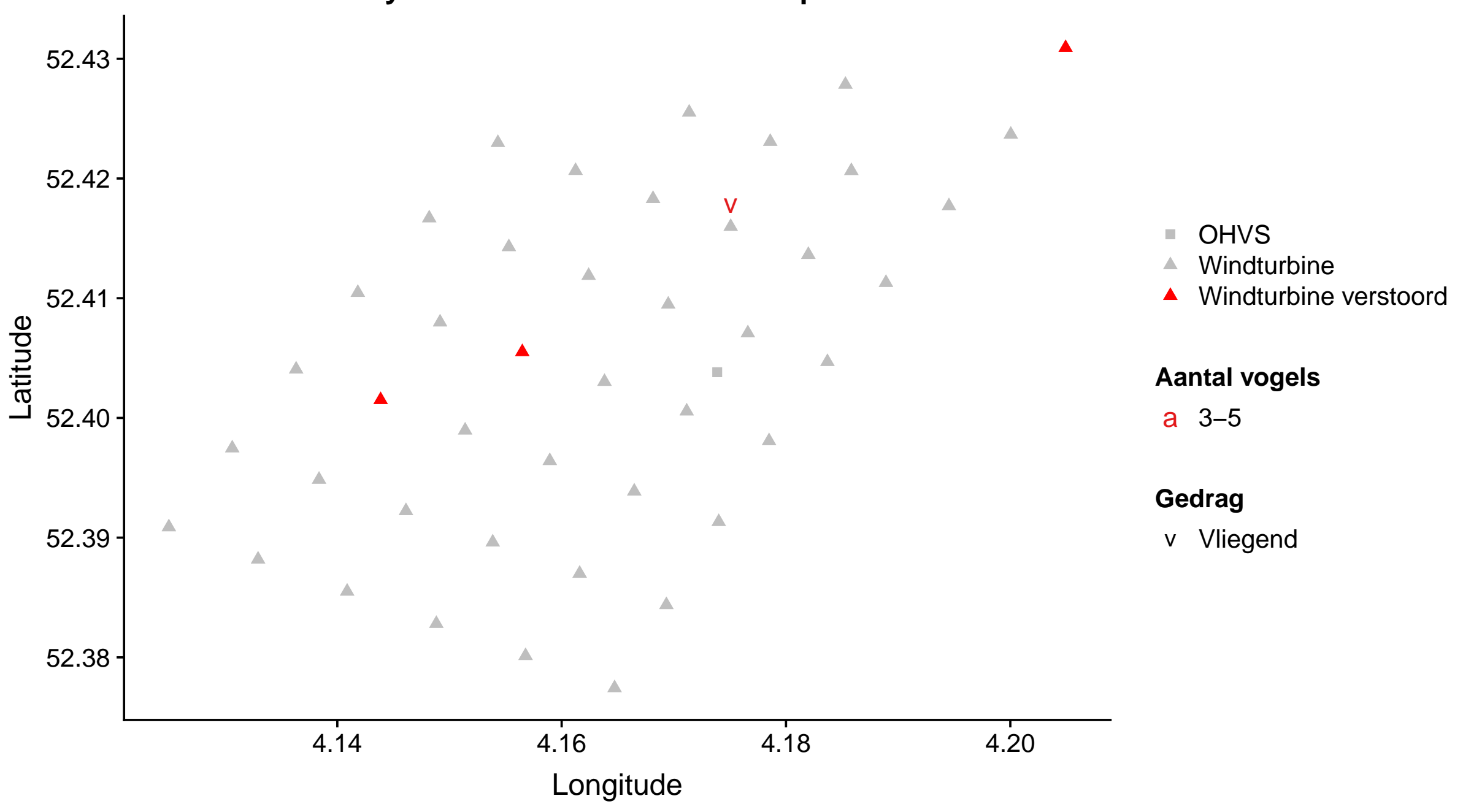


Survey 5: Rotgans in windmolenpark OWEZ

$\frac{0}{0}$

52.61

$\Delta$

$\Delta$

52.60

52.59

52.58
$\Delta$

$\Delta$

Aantal vogels

a 1-2

Gedrag

v Vliegend

- Meetmast

Windturbine

- Windturbine verstoord

$\begin{array}{lrrrr}4.38 & 4.40 & 4.42 & 4.44 & 4.46 \\ & & & \end{array}$


Survey 4: Slechtvalk in windmolenpark LUD

$\frac{0}{\frac{0}{2}}$

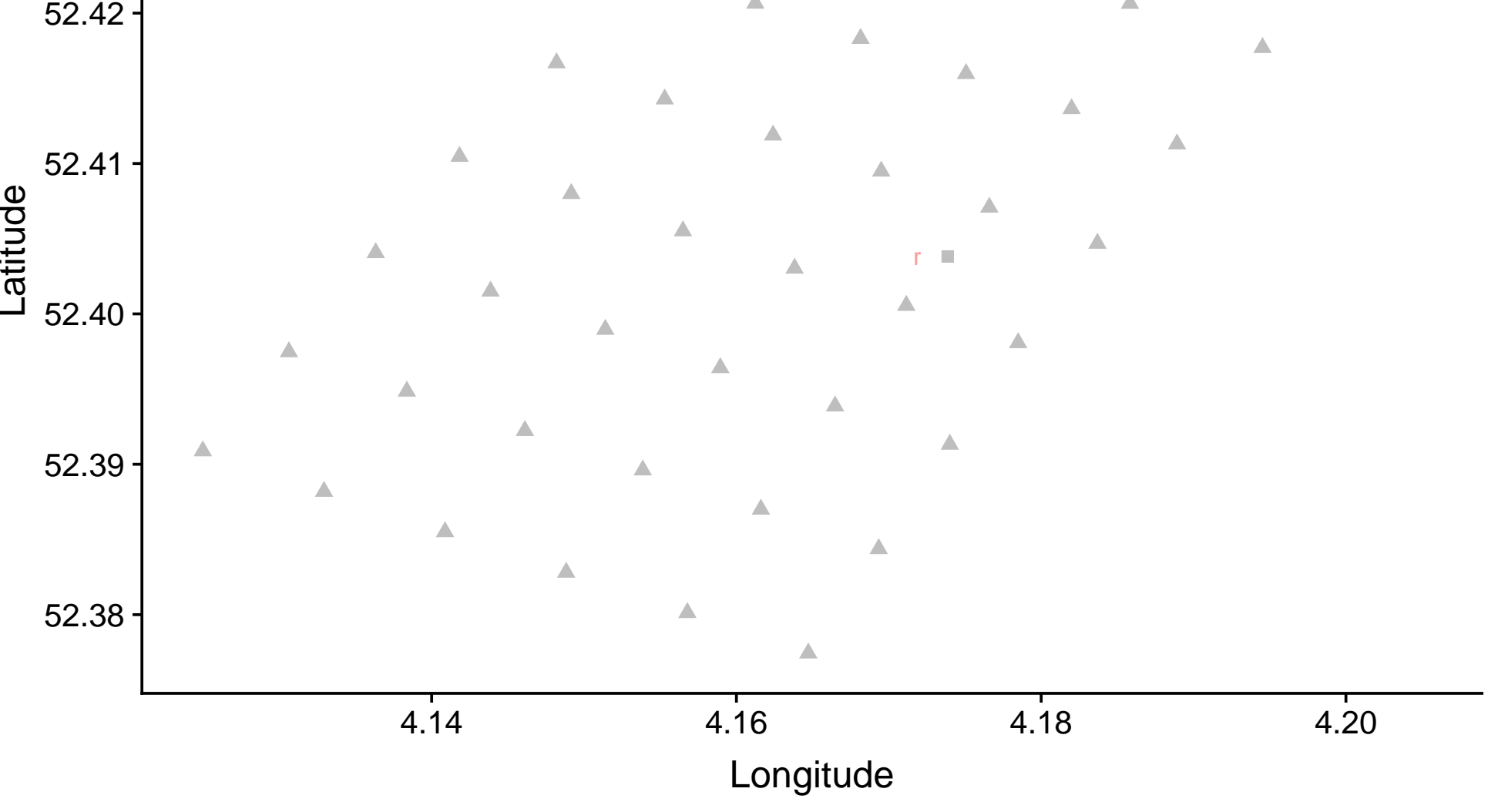

- OHVS

Windturbine

Aantal vogels

a 1-2

Gedrag

Rustend op de turbinefundatie 
Survey 5: Slechtvalk in windmolenpark LUD

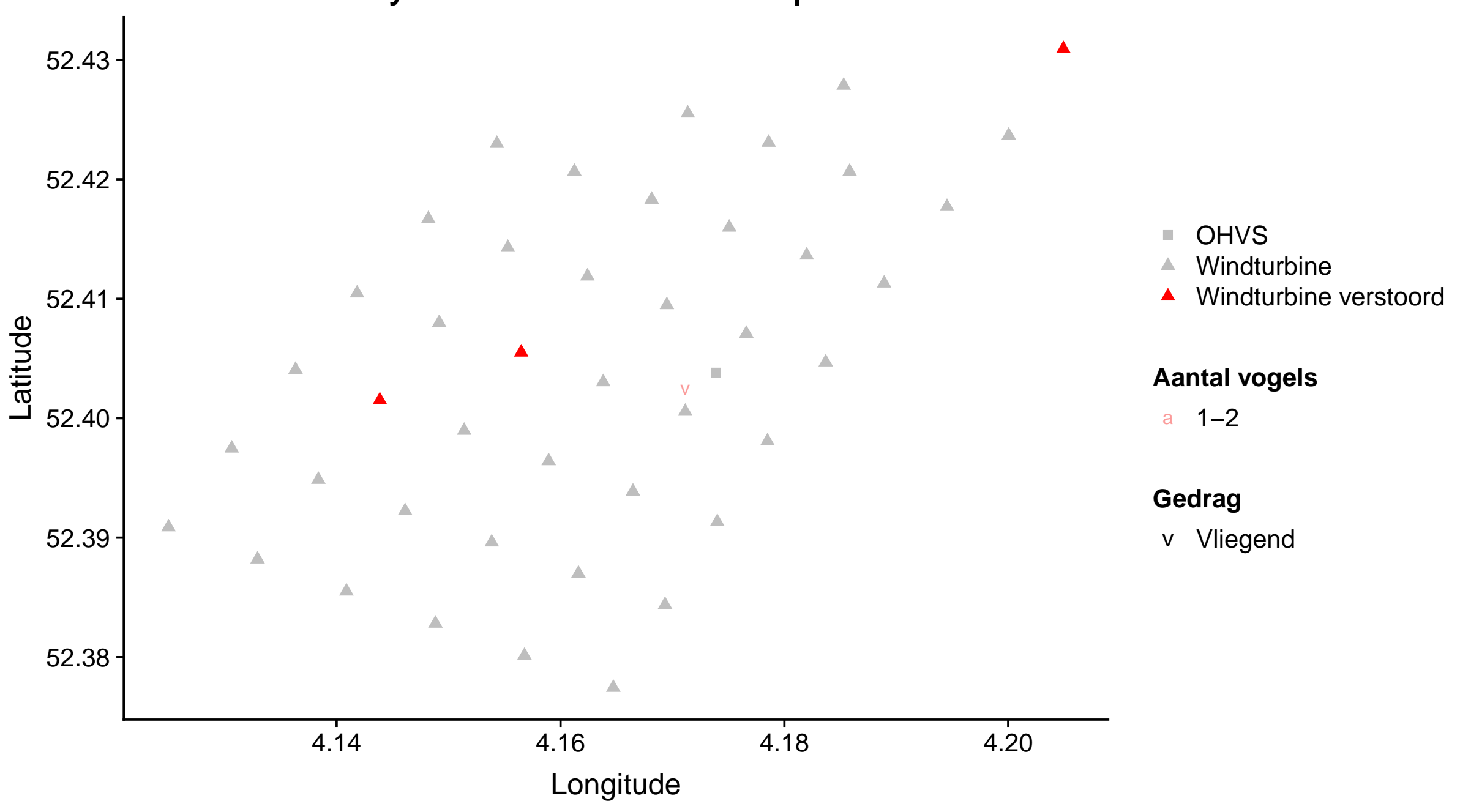


Survey 5: Spreeuw in windmolenpark OWEZ

$\frac{0}{0}$

旁

52.60

52.59

$\Delta$

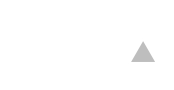

$\Delta$

Aantal vogels

a 11-25

Gedrag

$\checkmark$ Vliegend

- Meetmast

$\triangle$ Windturbine

- Windturbine verstoord

52.58

4.38

4.40

4.42

4.44

Longitude 


\section{Survey 5: Spreeuw in windmolenpark PAWP}

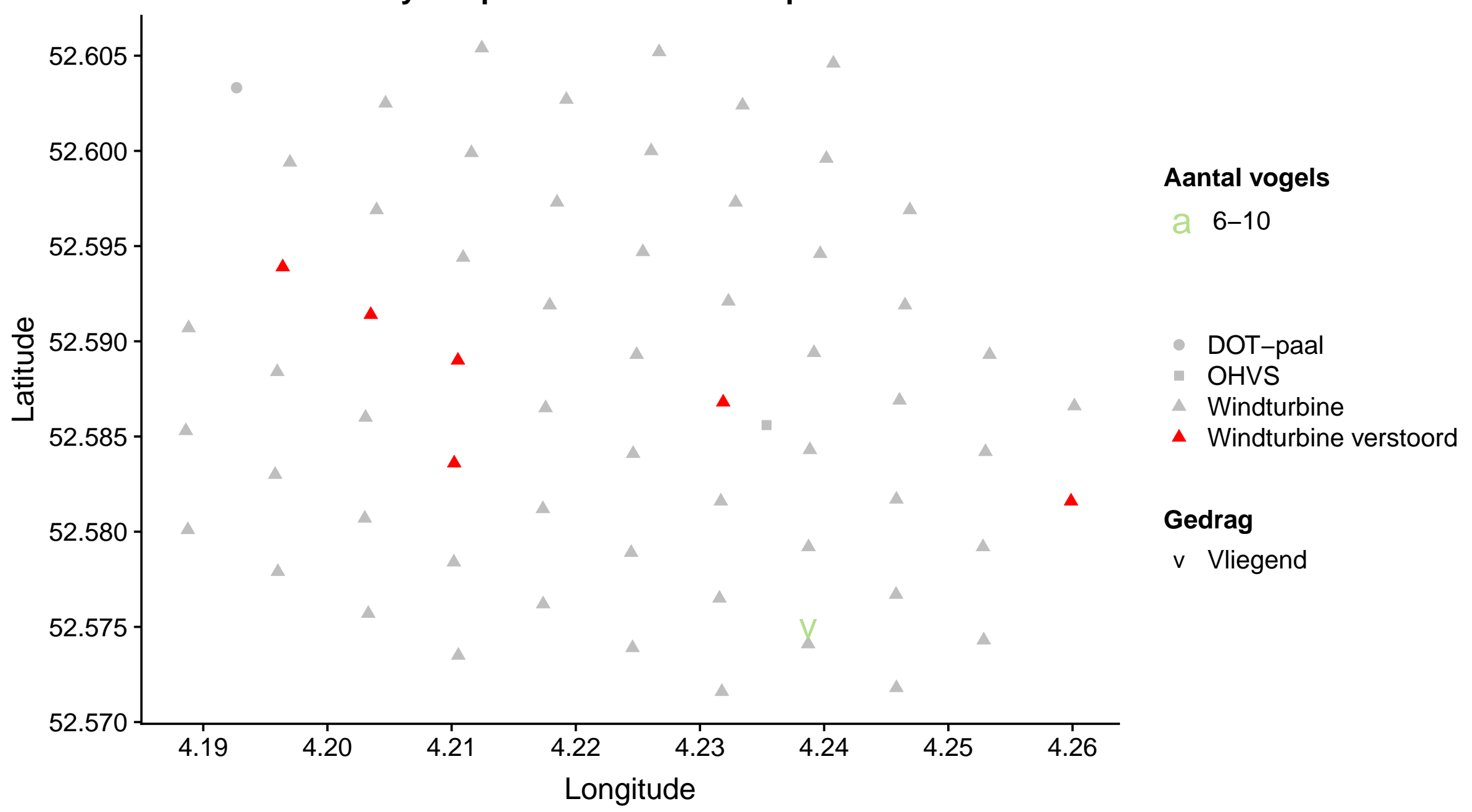




\section{Survey 1: Stormmeeuw in windmolenpark OWEZ}

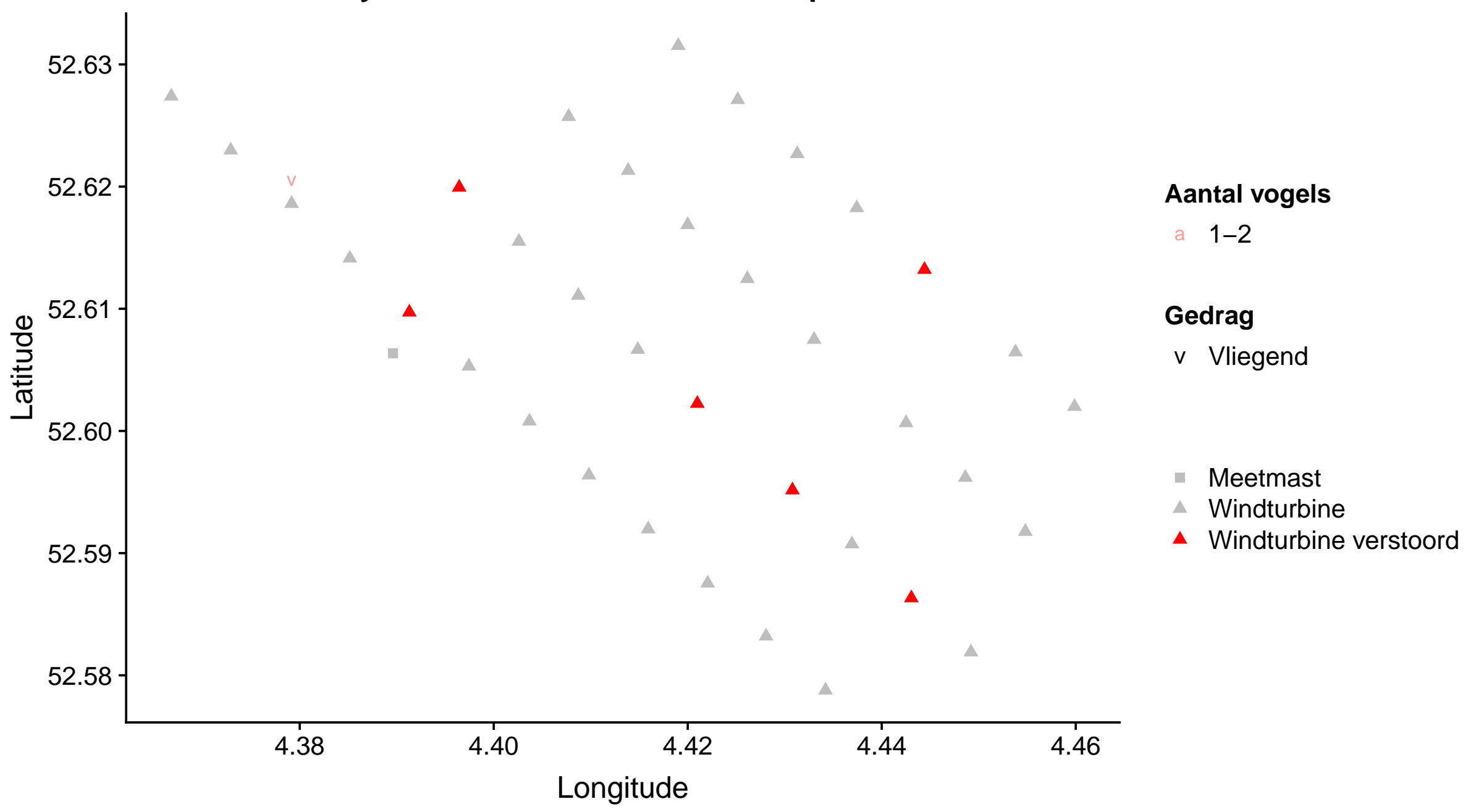




\section{Survey 2: Stormmeeuw in windmolenpark OWEZ}

$\frac{9}{2}$

52.59

$\Delta$ 1<smiles>C1CCCCCC1</smiles>
(1)

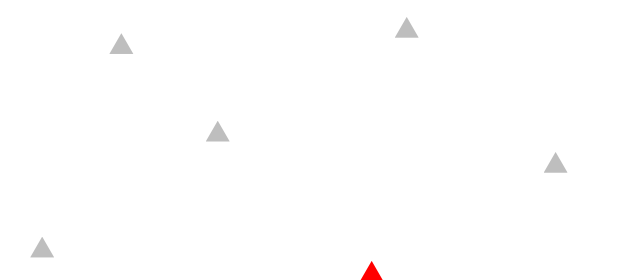
$\triangle$
Aantal vogels

a 1-2

Gedrag

$\checkmark$ Vliegend

- Meetmast

Windturbine

- Windturbine verstoord 
Survey 2: Stormmeeuw in windmolenpark LUD

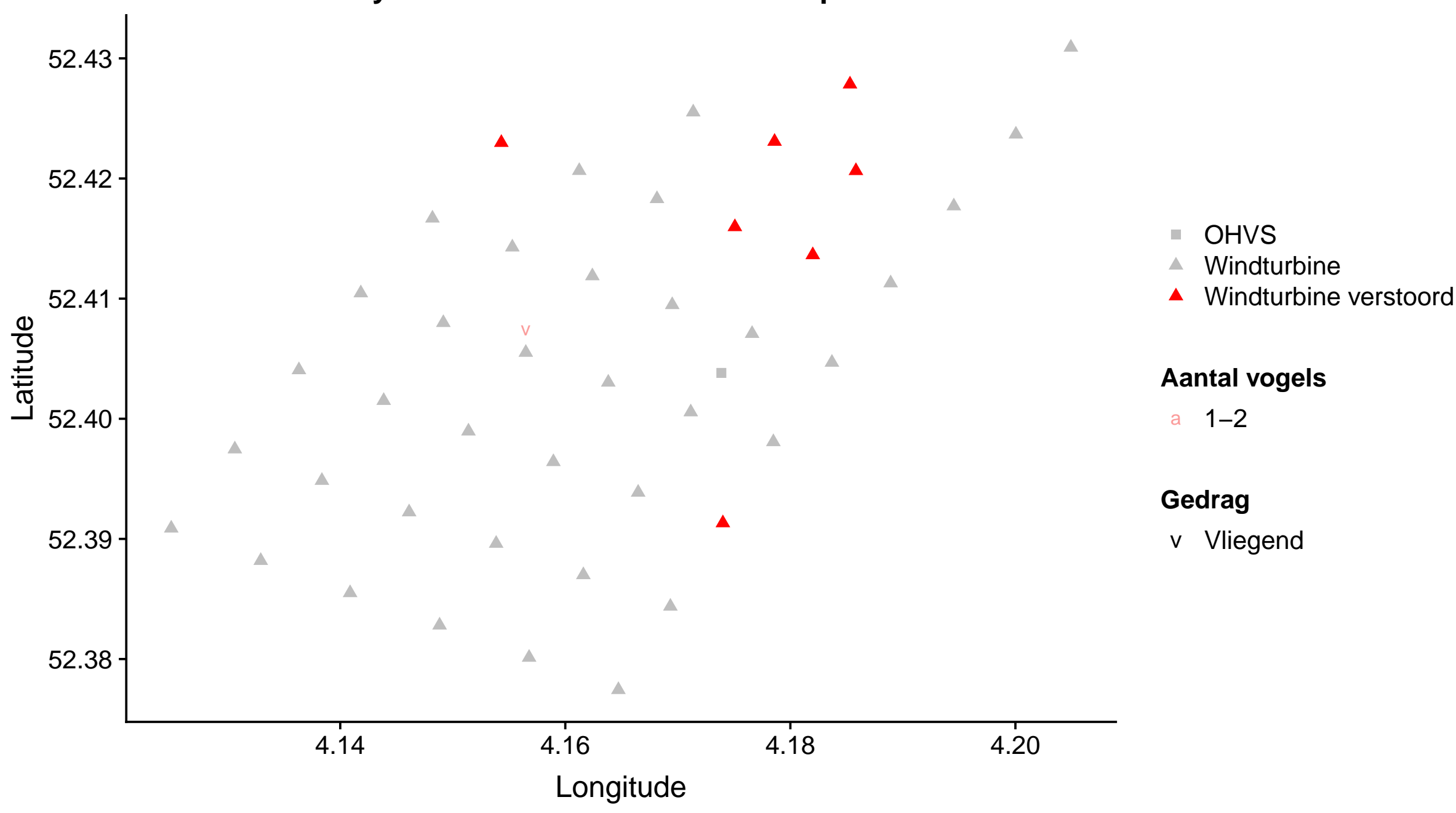


Survey 5: Stormmeeuw in windmolenpark LUD

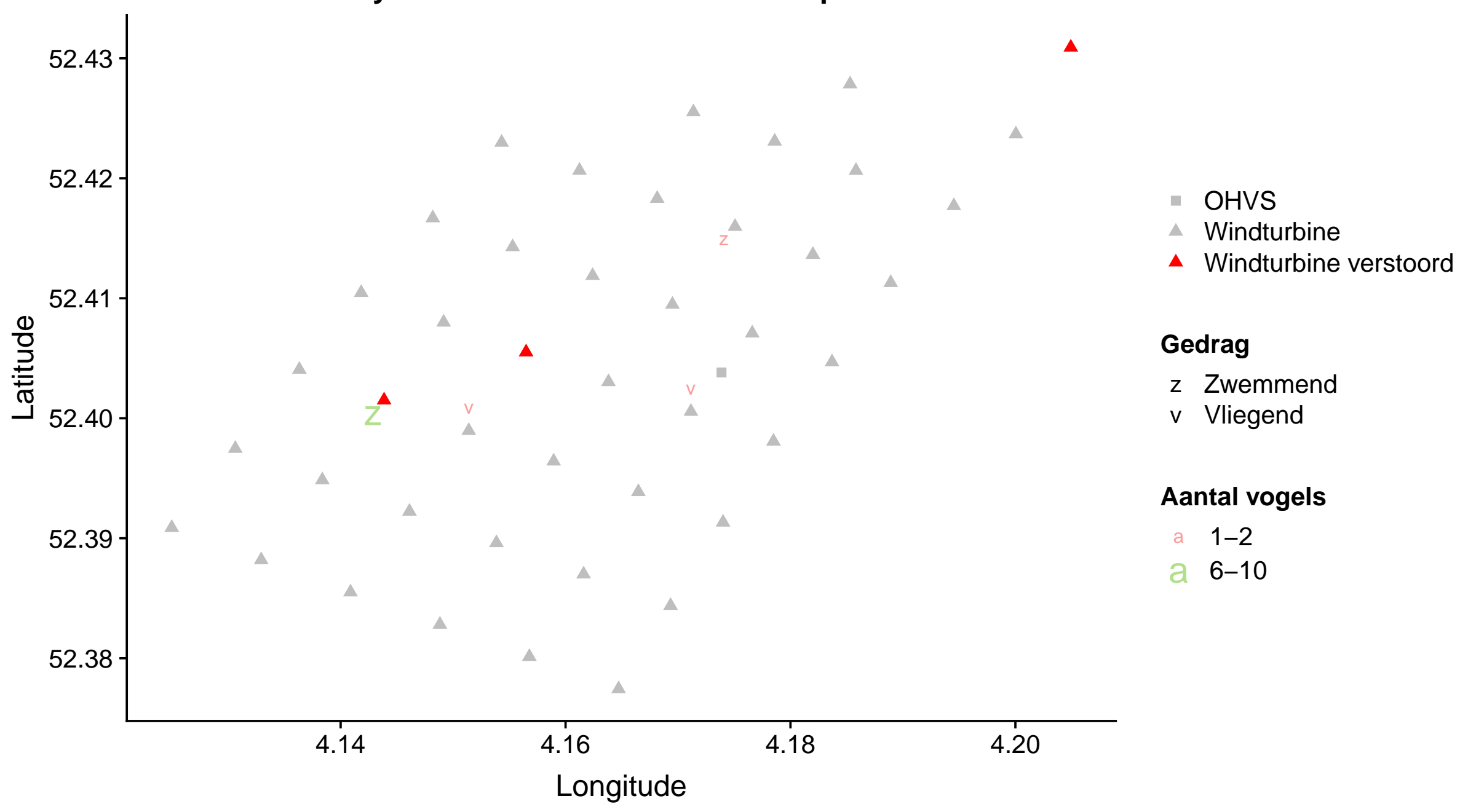


Survey 5: Stormmeeuw in windmolenpark OWEZ

을 52.62

$\Delta$

$\Delta$

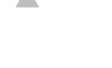

$\Delta$

(1)

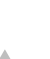

$\Delta$

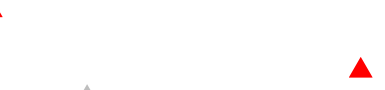

$\Delta$ $\Delta$
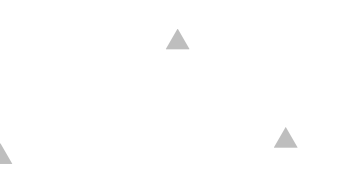

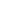

z Zwemmend

$\checkmark$ Vliegend

Aantal vogels

a 1-2

\section{Gedrag}

- Meetmast

- Windturbine

- Windturbine verstoord

$\begin{array}{lrrrr}4.38 & 4.40 & \begin{array}{c}4.42 \\ \text { Longitude }\end{array} & 4.44 & 4.46 \\ & & & \end{array}$




\section{Survey 2: Zeekoet in windmolenpark LUD}

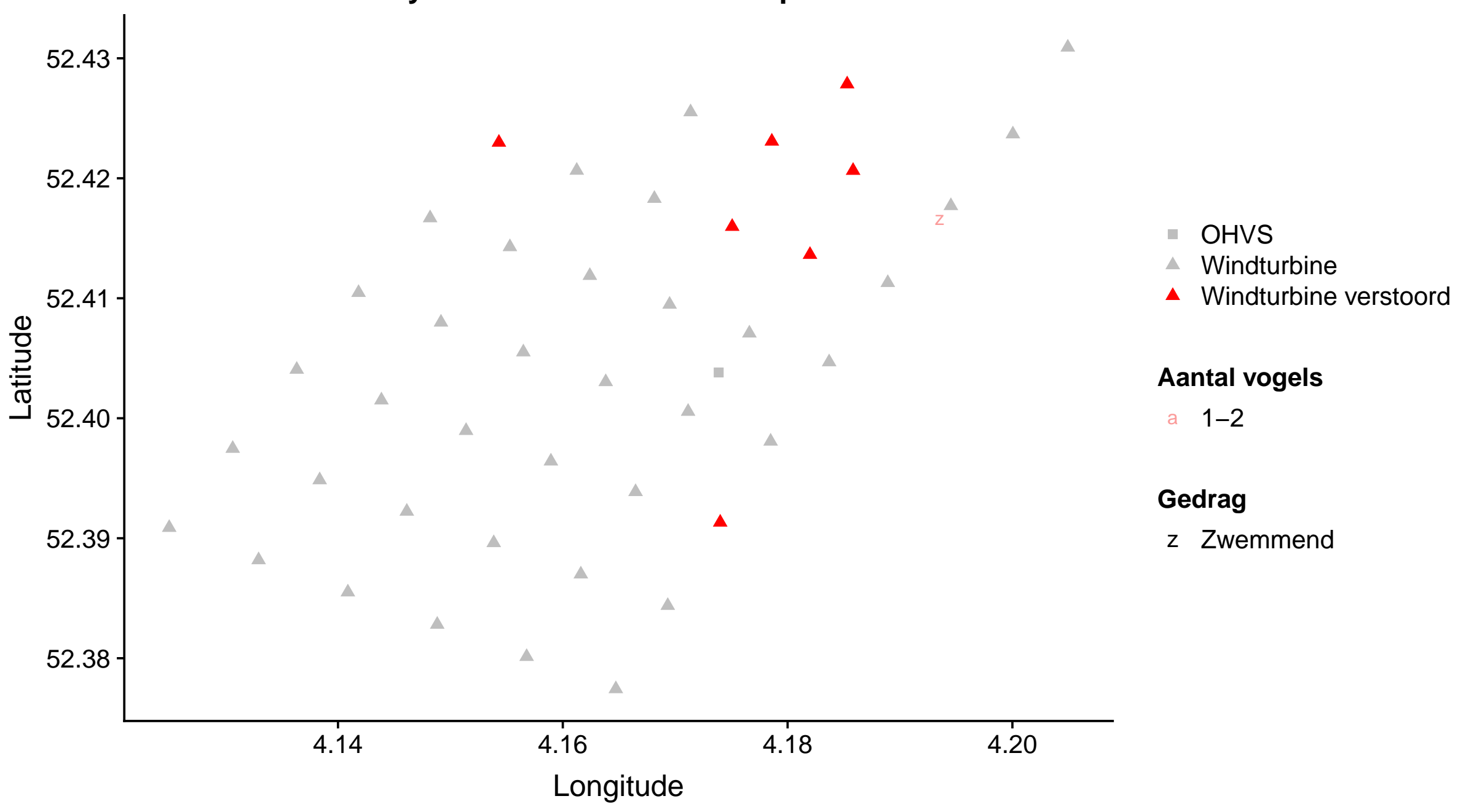


Survey 3: Zeekoet in windmolenpark PAWP

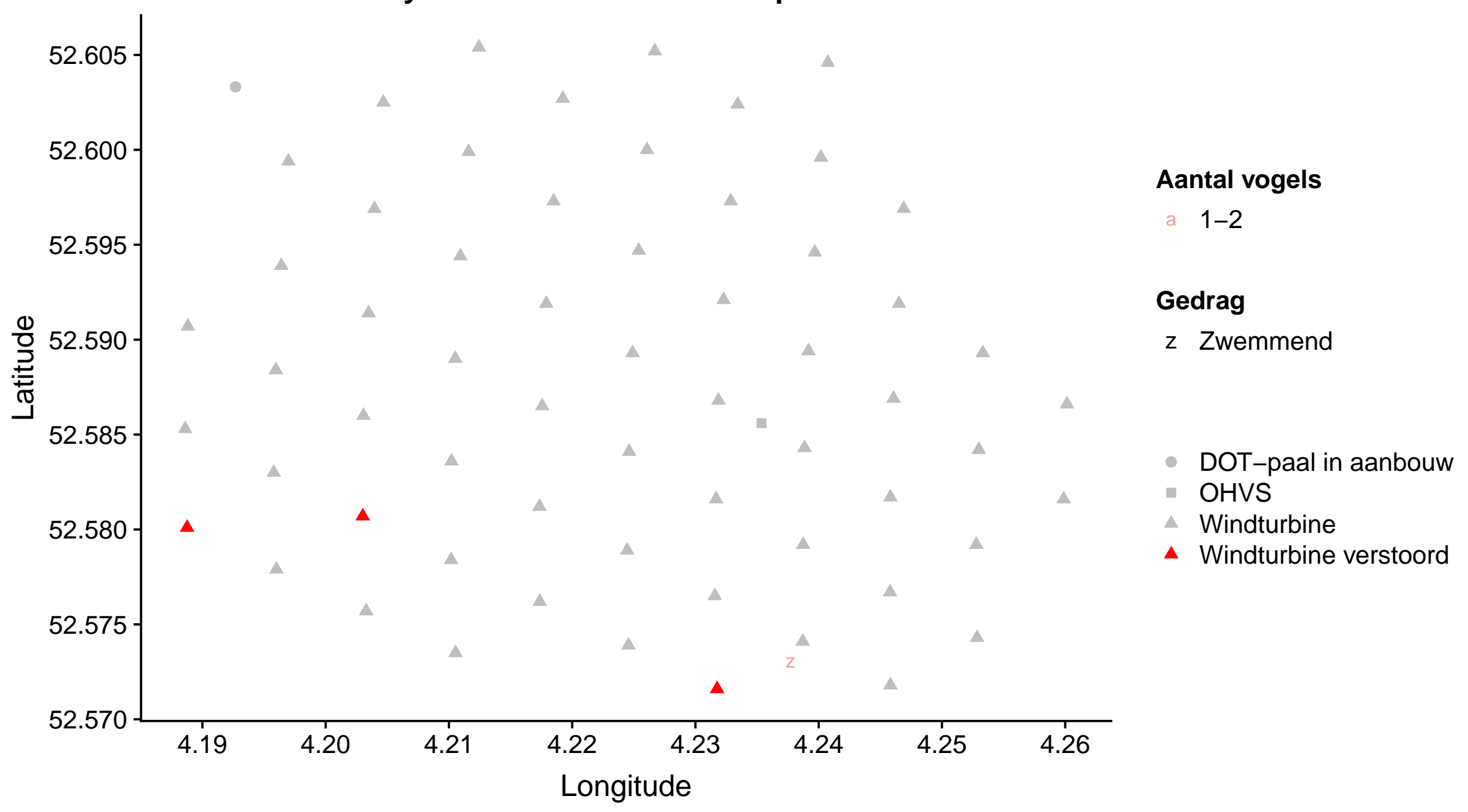




\section{Survey 3: Zeekoet in windmolenpark LUD}

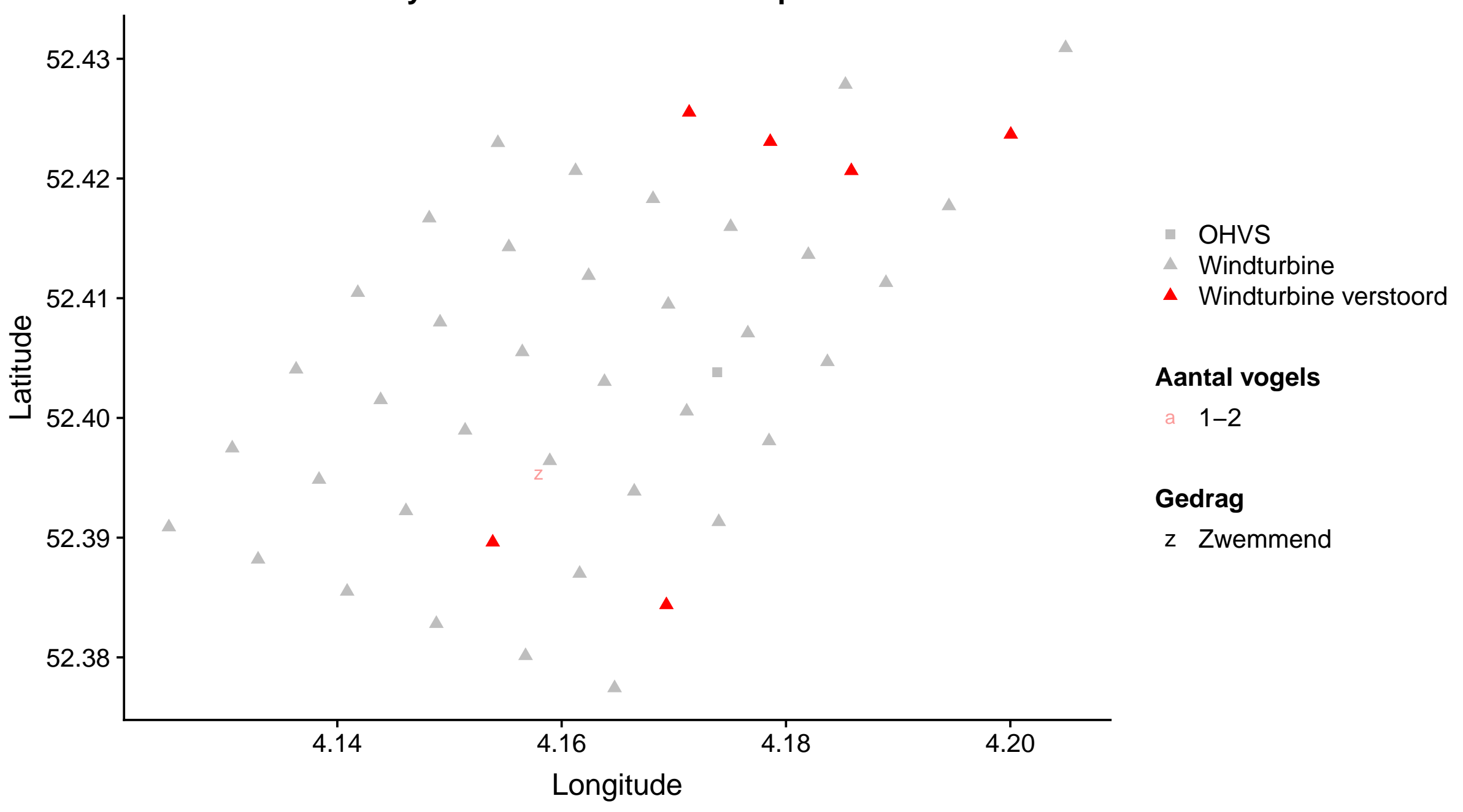




\section{Survey 4: Zeekoet in windmolenpark OWEZ}

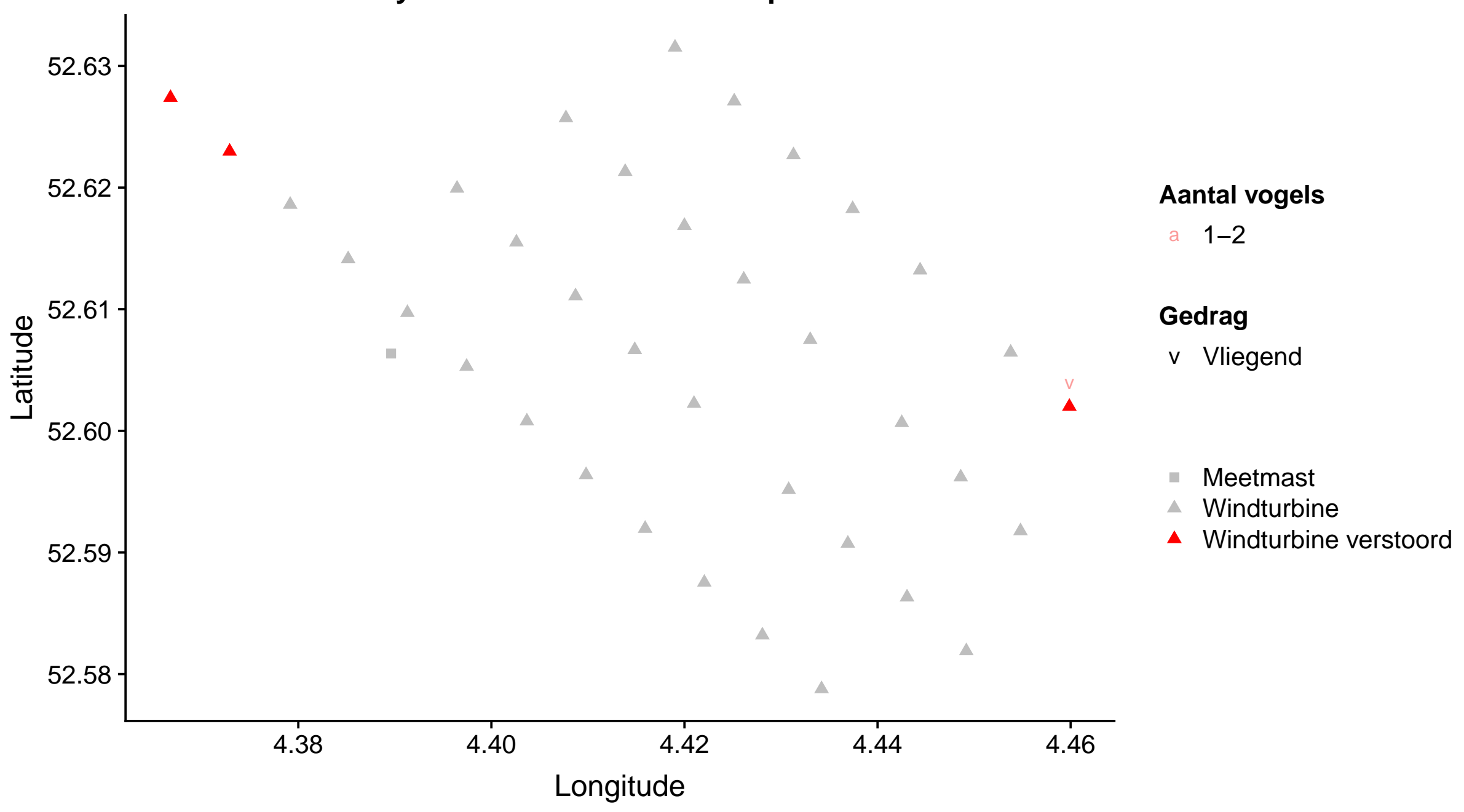


Survey 4: Zeekoet in windmolenpark LUD

道

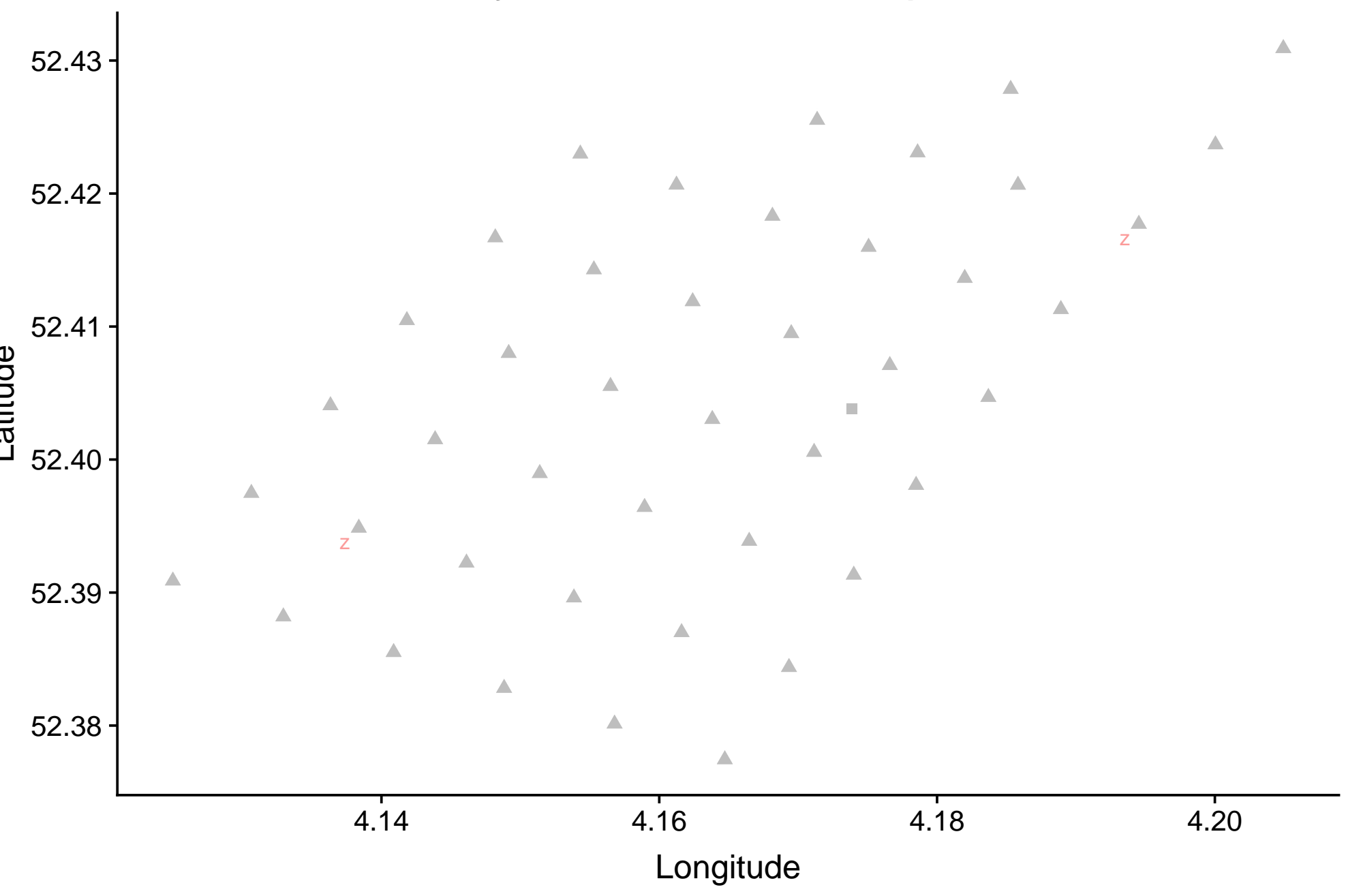

- OHVS

- Windturbine

Aantal vogels

a 1-2

Gedrag

z Zwemmend 


\section{Survey 5: Zeekoet in windmolenpark OWEZ}

$\frac{1}{0}$

$\Delta$

<

$\boldsymbol{A}$

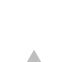

5
$\Delta$ $\Delta$ (1)
$\Delta$

52.59
$\Delta$

Aantal vogels

a 1-2

\section{Gedrag}

z Zwemmend

- Meetmast

- Windturbine

- Windturbine verstoord

$\begin{array}{lrrrr}4.38 & 4.40 & \begin{array}{c}4.42 \\ \text { Longitude }\end{array} & 4.44 & 4.46 \\ & & & \end{array}$


Survey 5: Zeekoet in windmolenpark PAWP

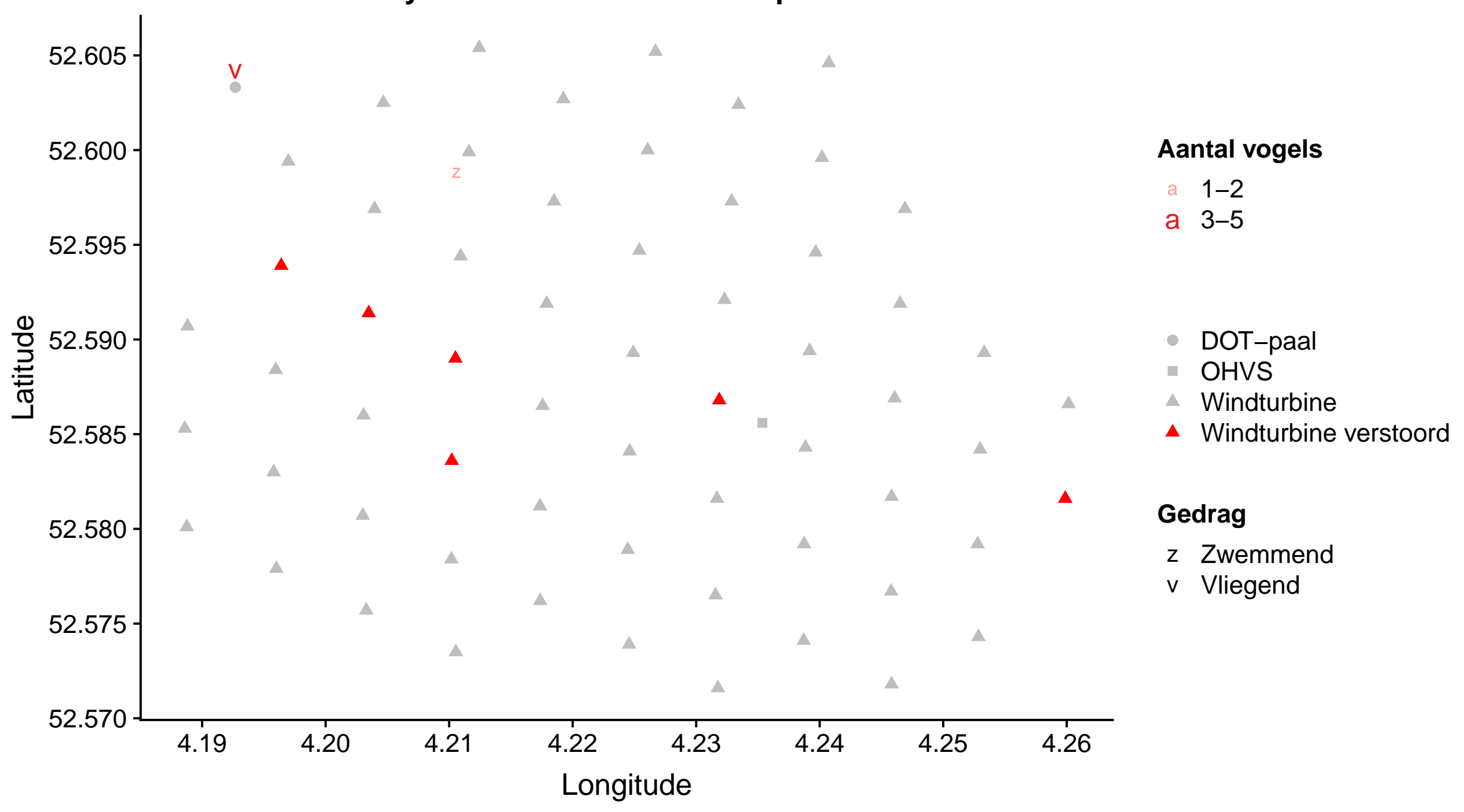




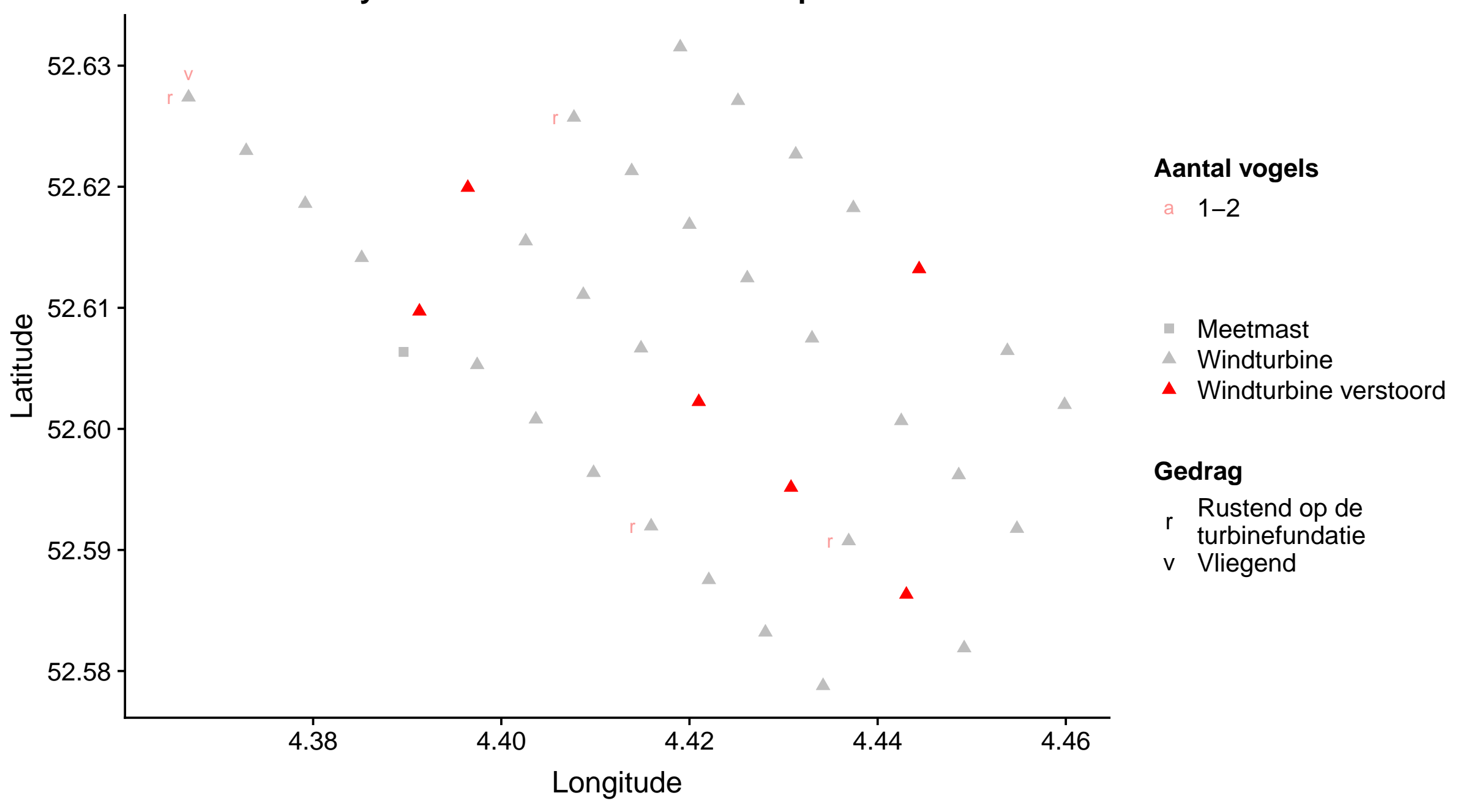


Survey 1: Zilvermeeuw in windmolenpark LUD

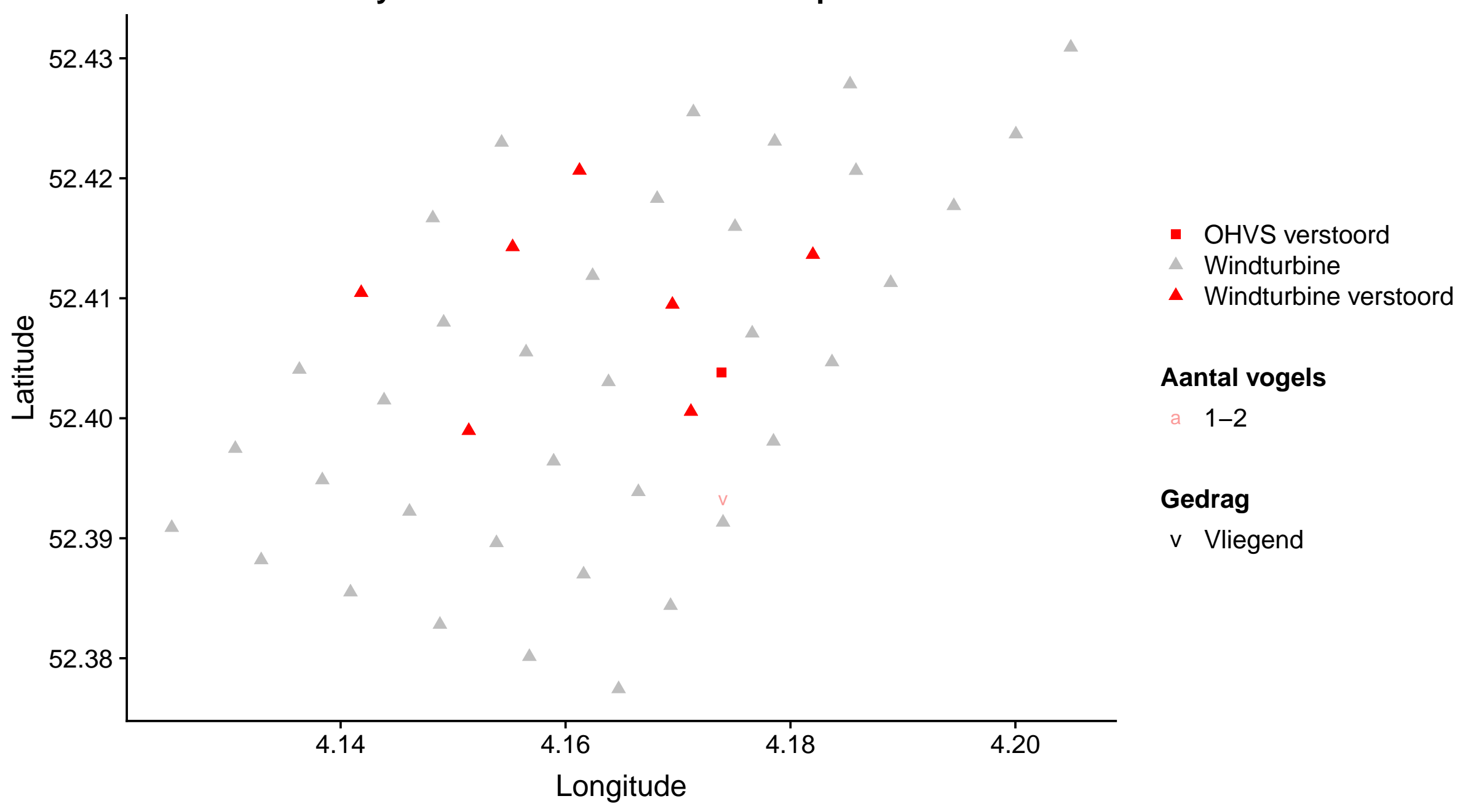




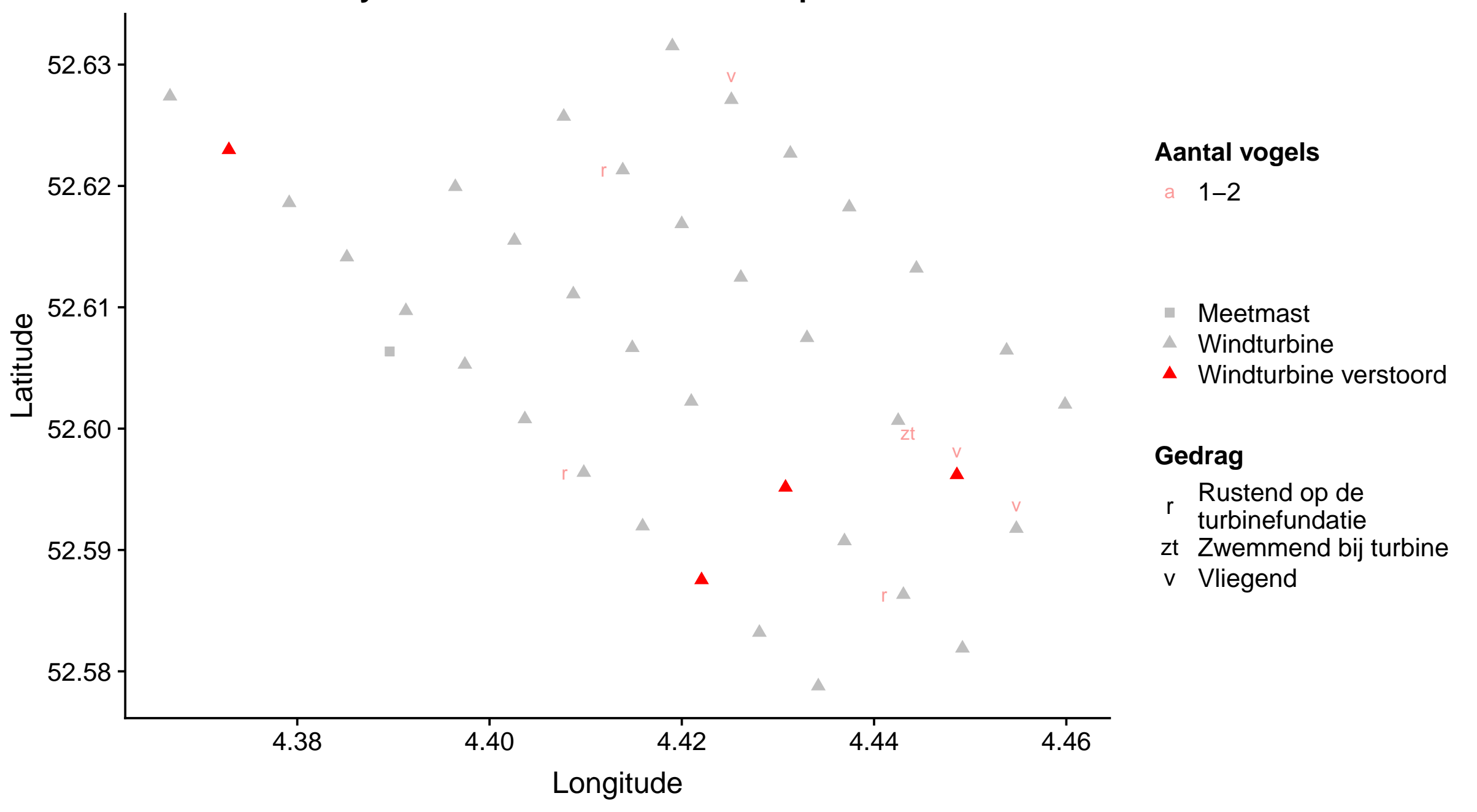




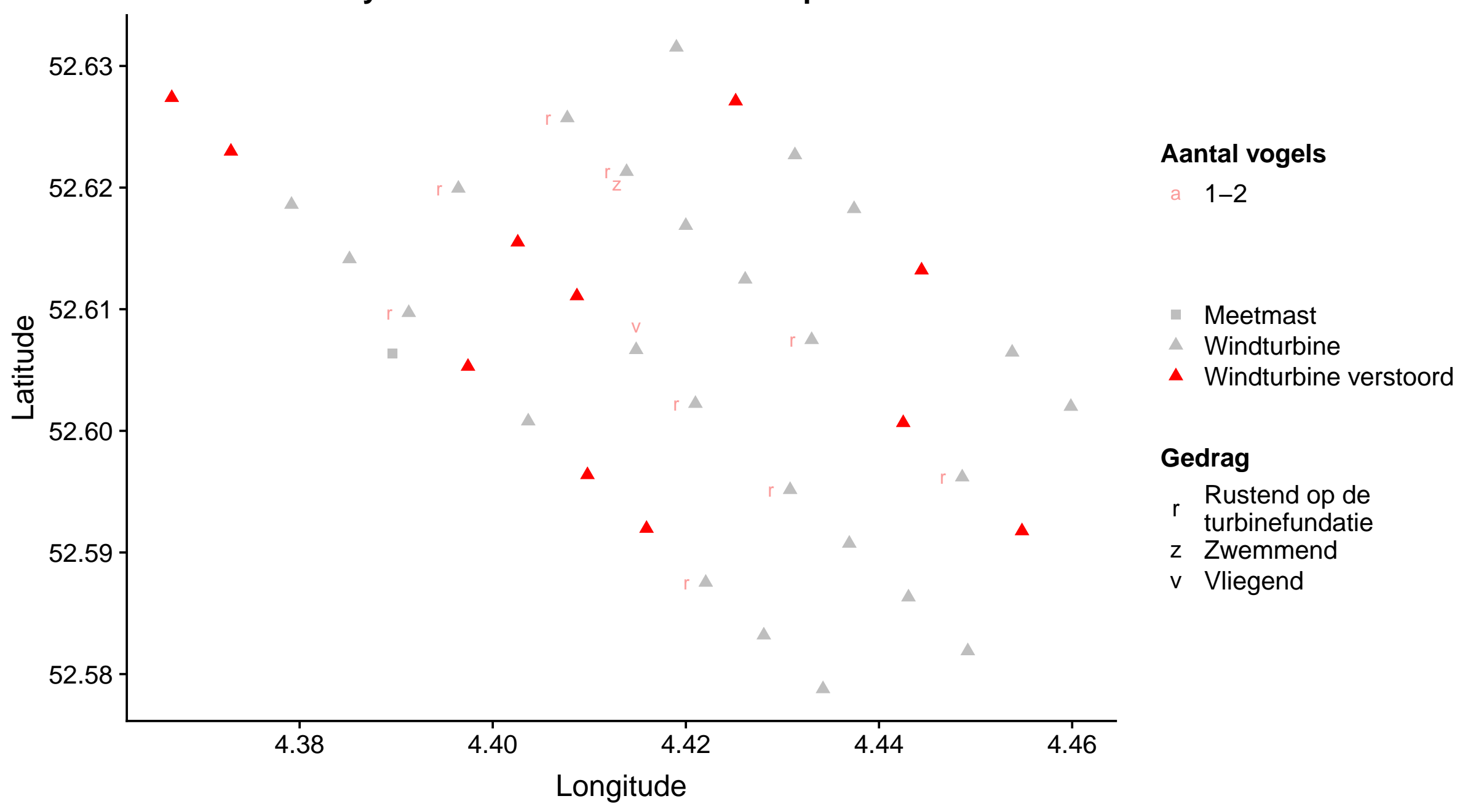


Survey 3: Zilvermeeuw in windmolenpark PAWP

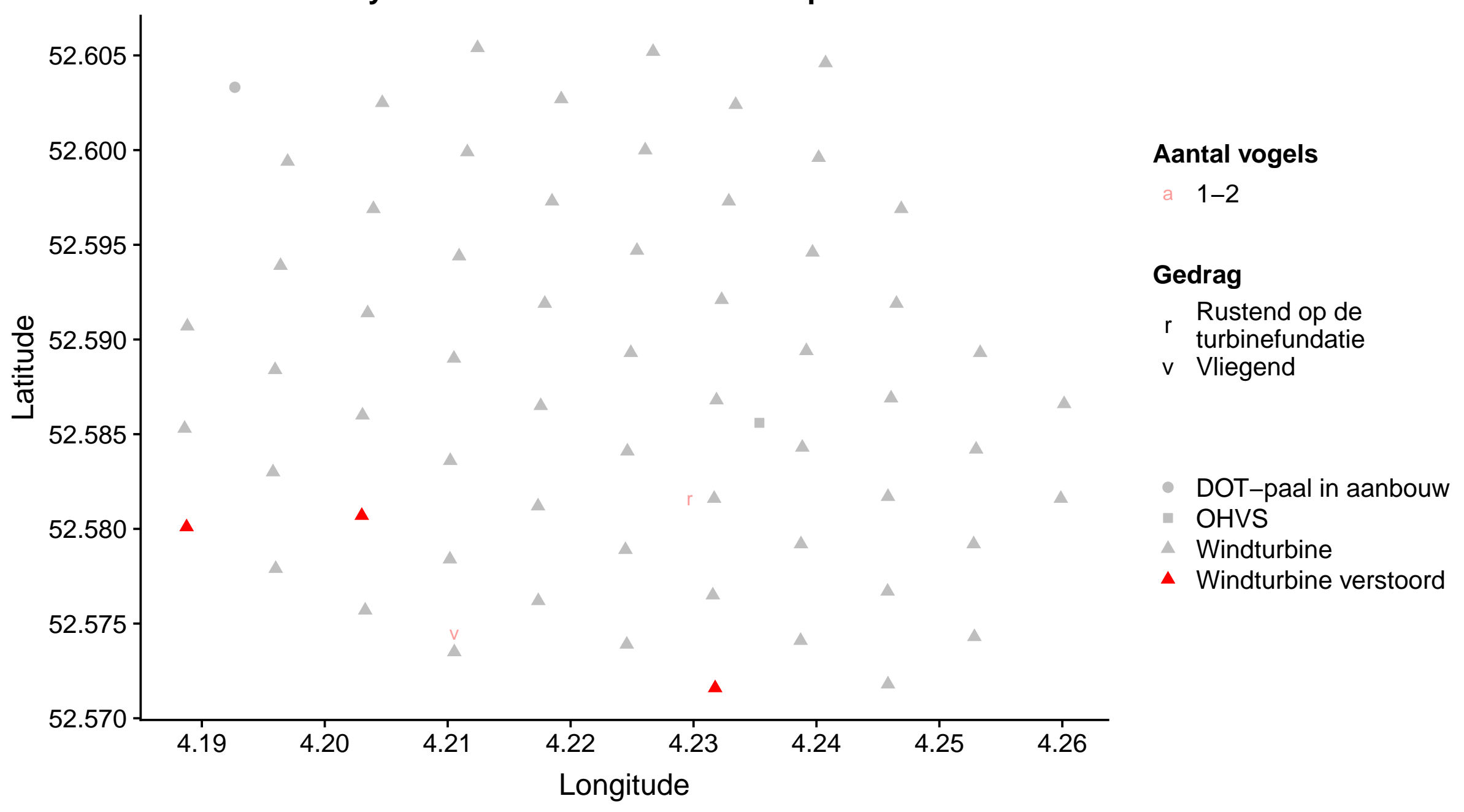


Survey 3: Zilvermeeuw in windmolenpark LUD

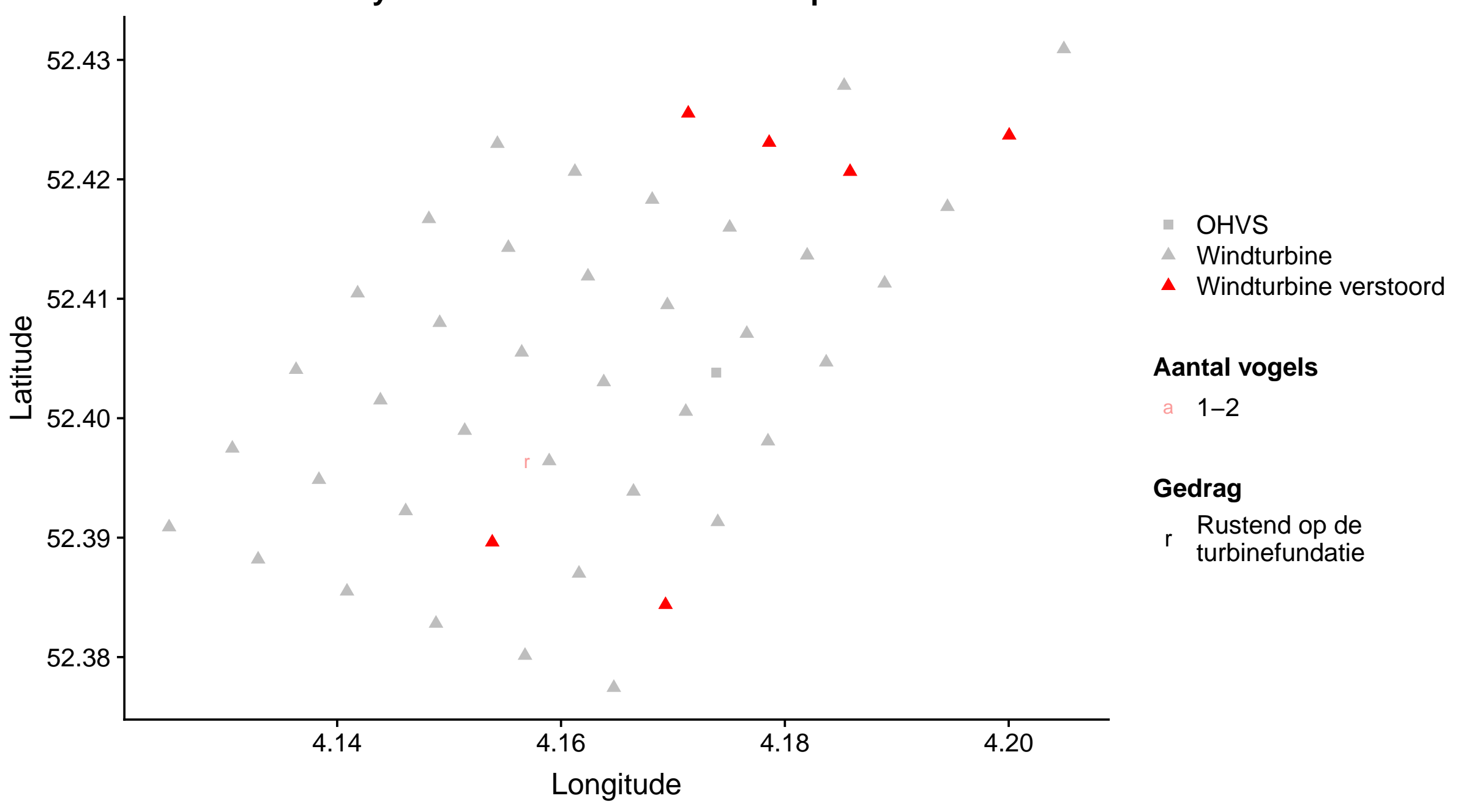




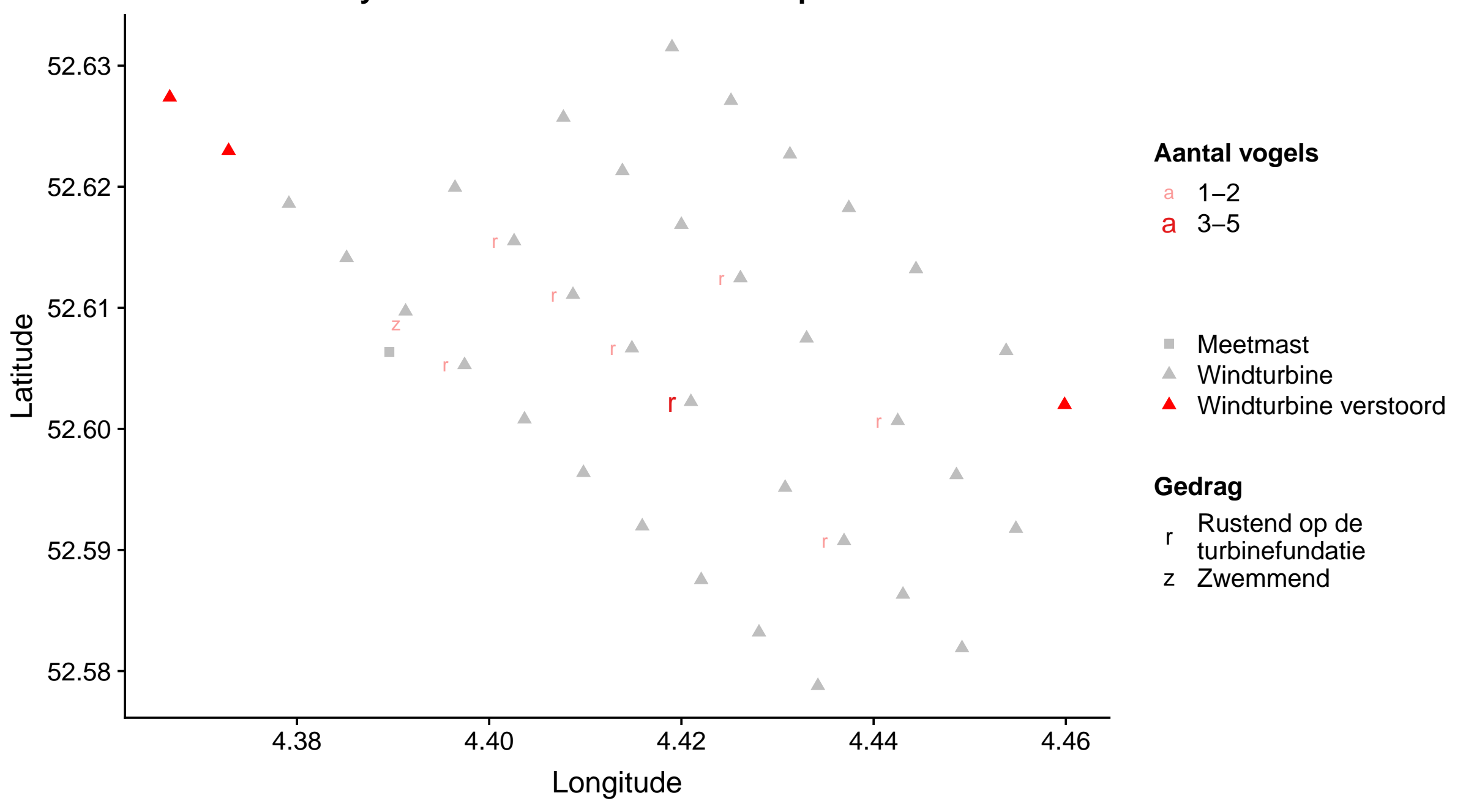


Survey 4: Zilvermeeuw in windmolenpark PAWP

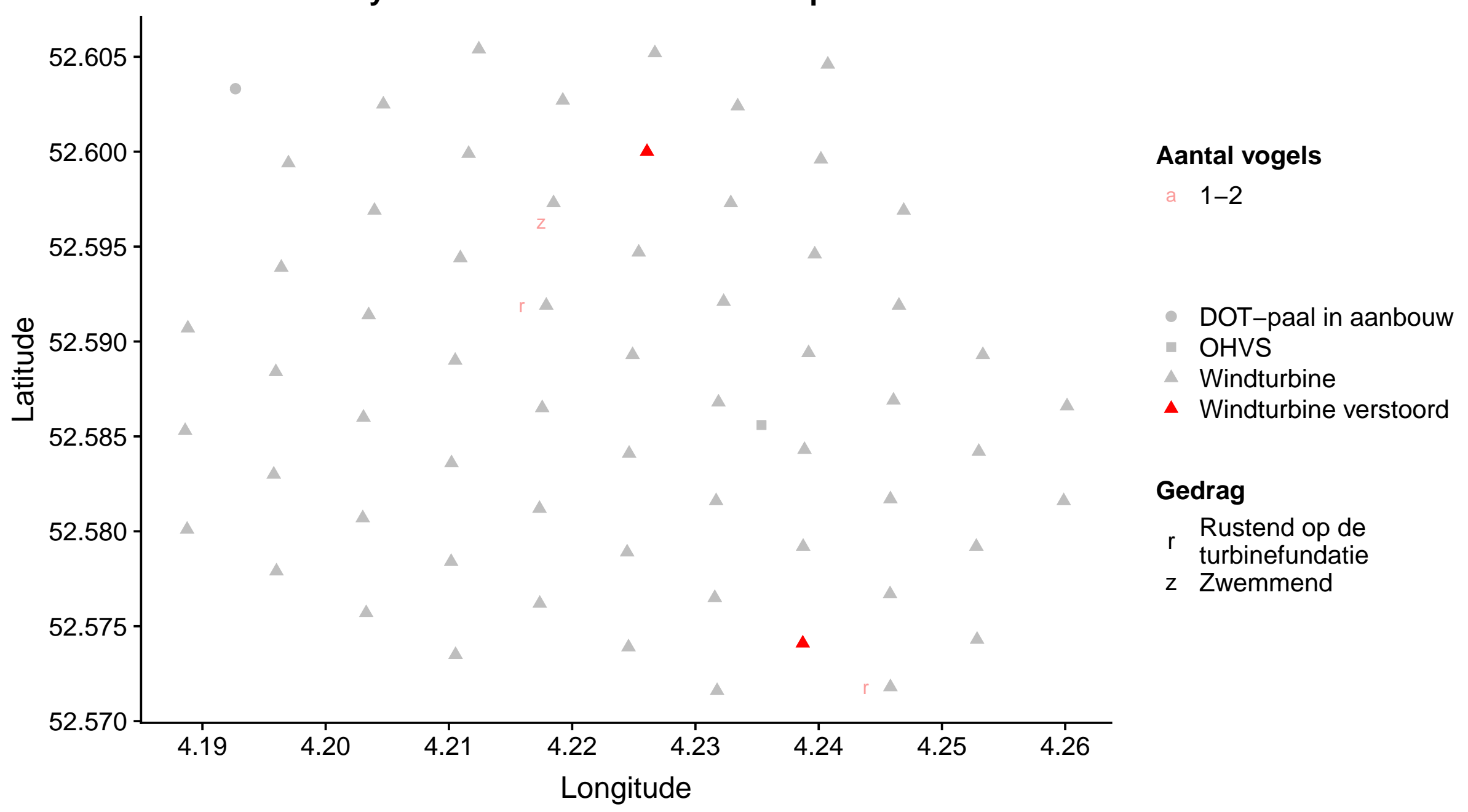


Survey 4: Zilvermeeuw in windmolenpark LUD

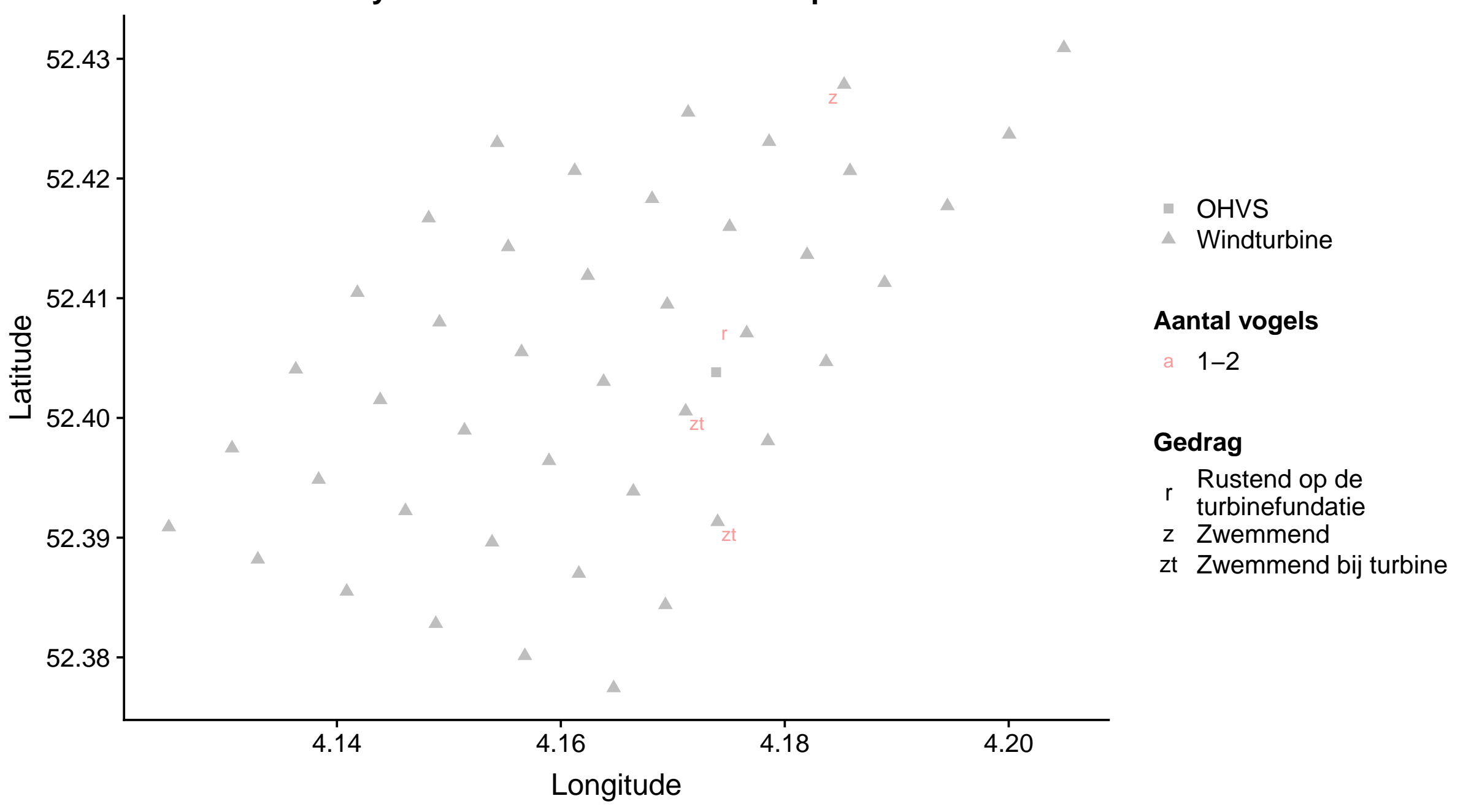




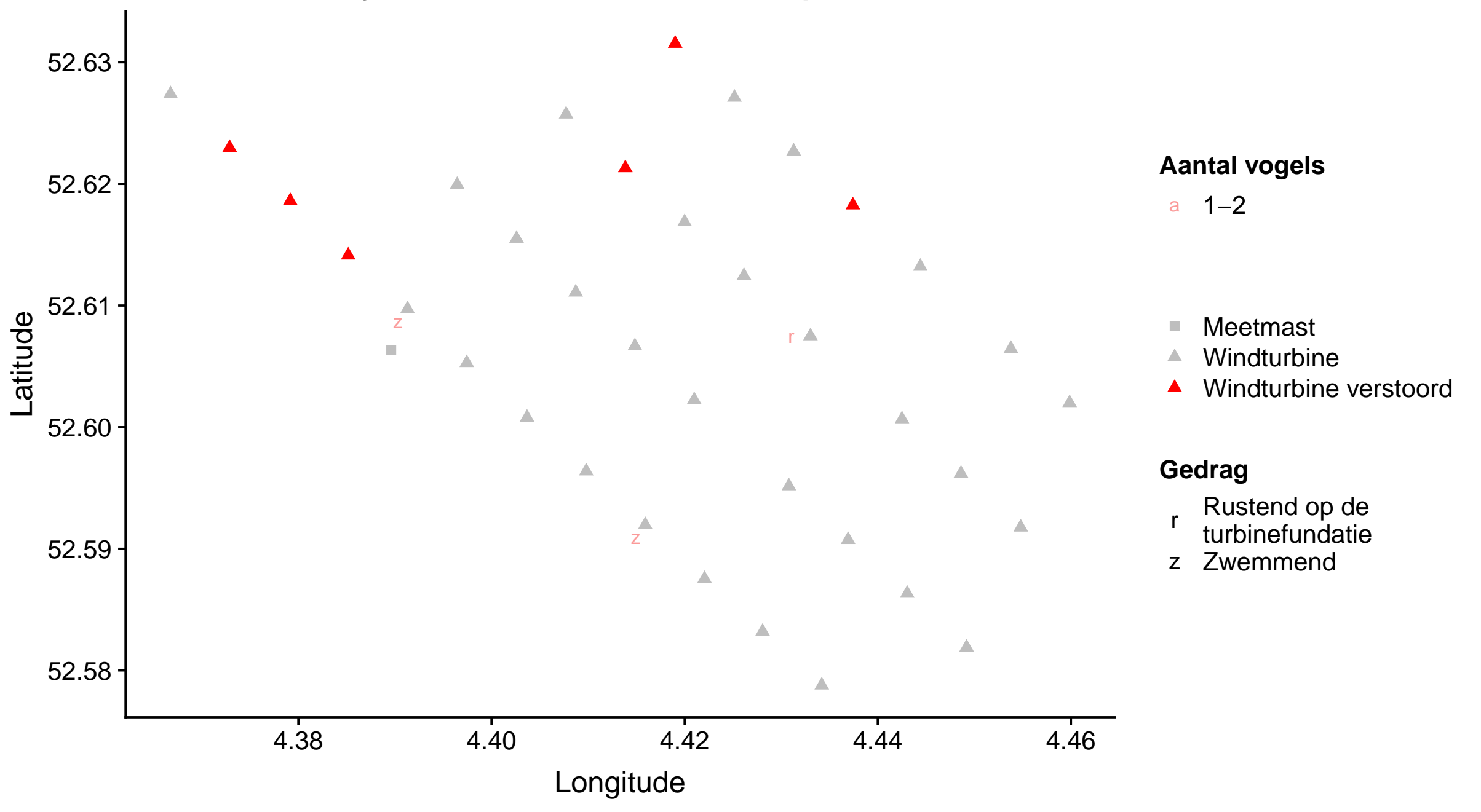


Survey 5: Zilvermeeuw in windmolenpark PAWP

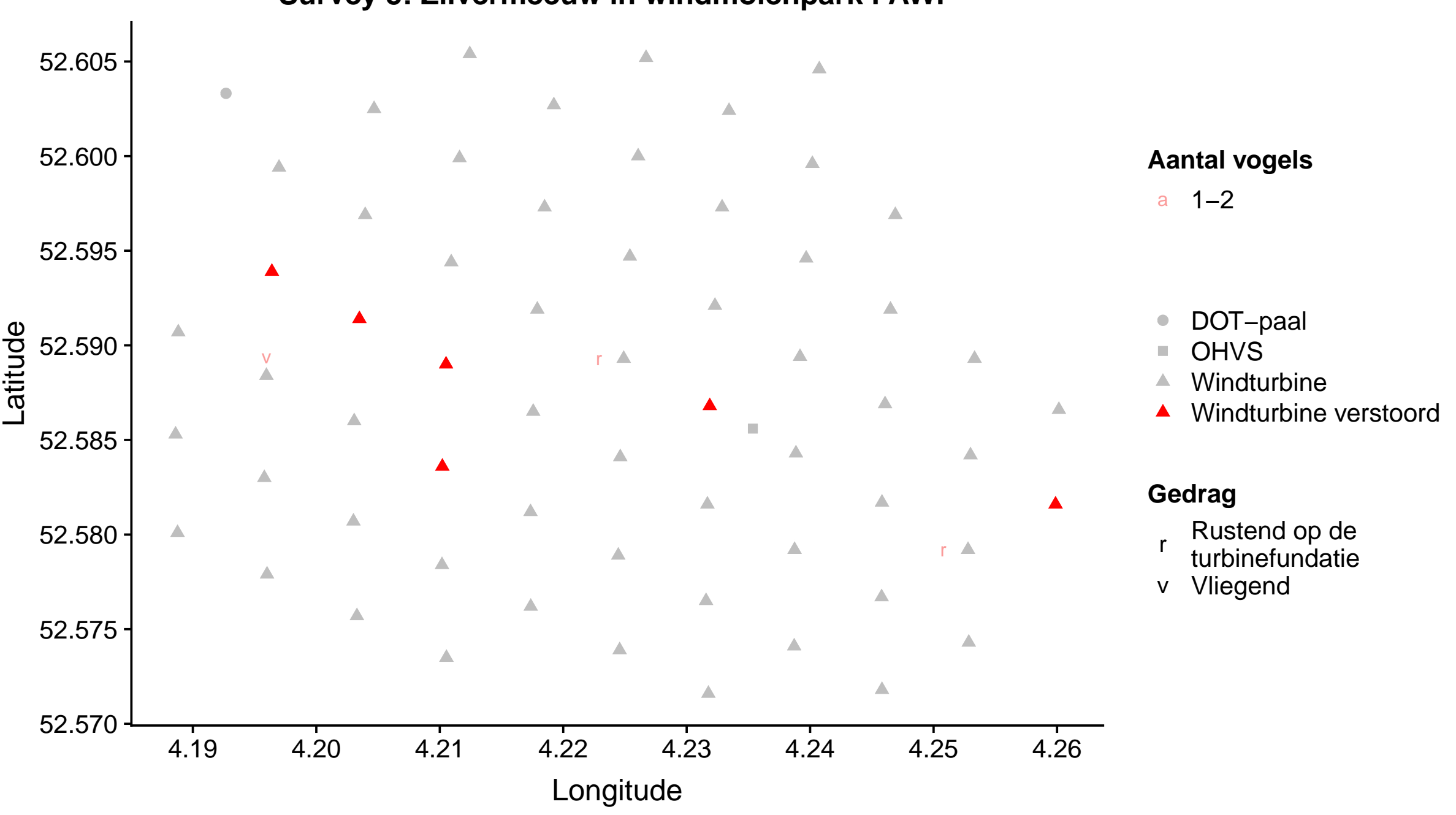


Survey 5: Zilvermeeuw in windmolenpark LUD

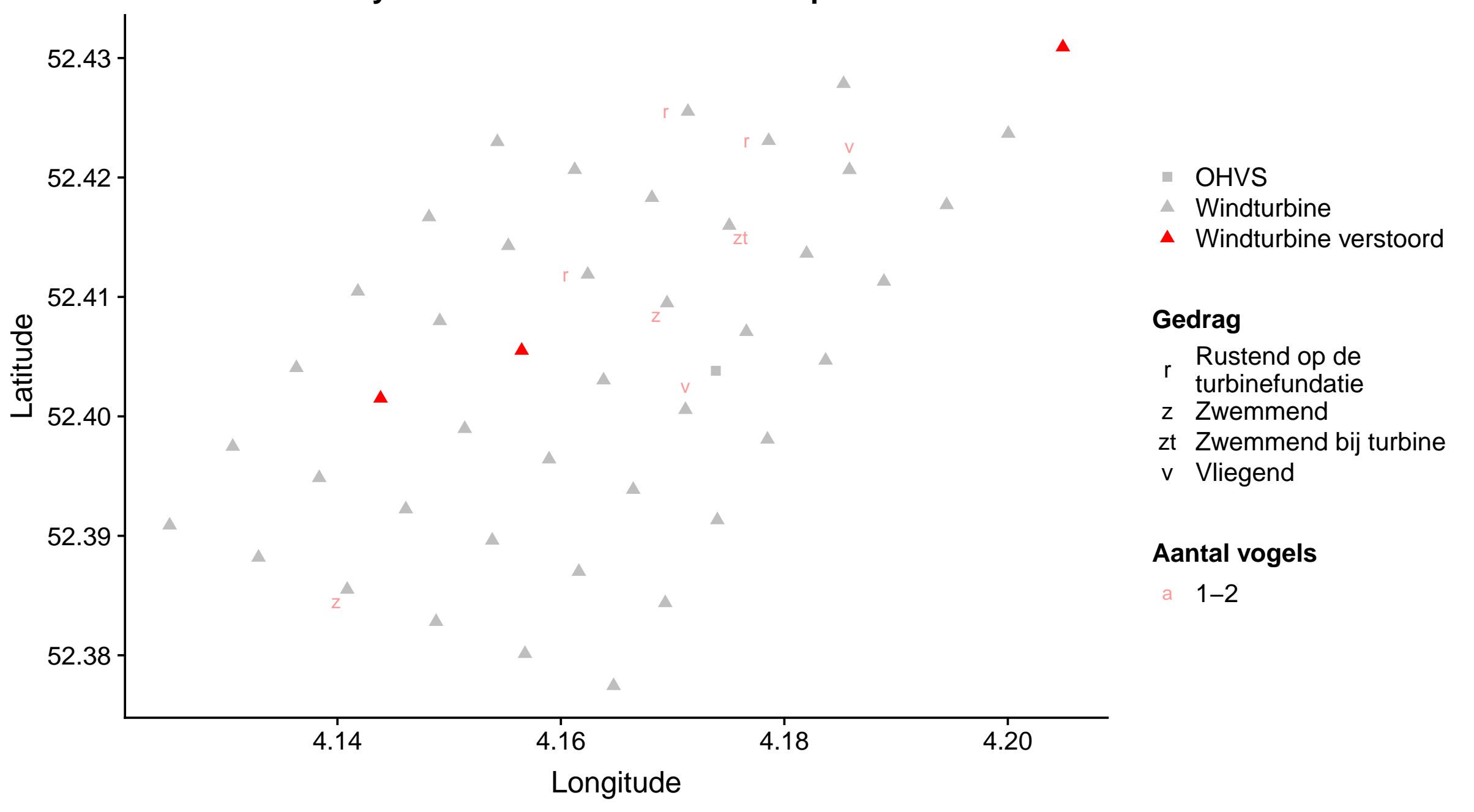


Survey 1: Bruinvis in windmolenpark OWEZ

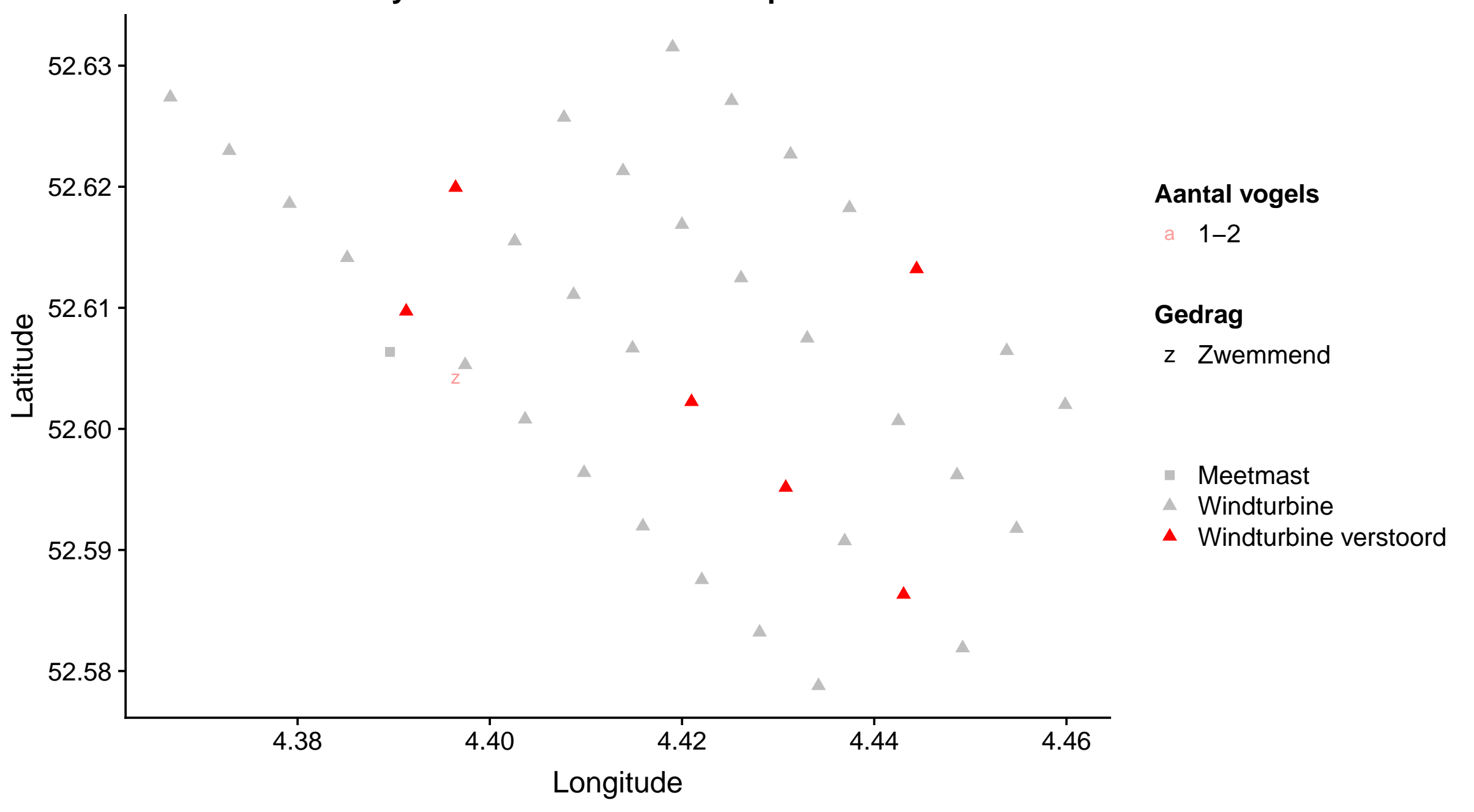


Survey 2: Bruinvis in windmolenpark LUD

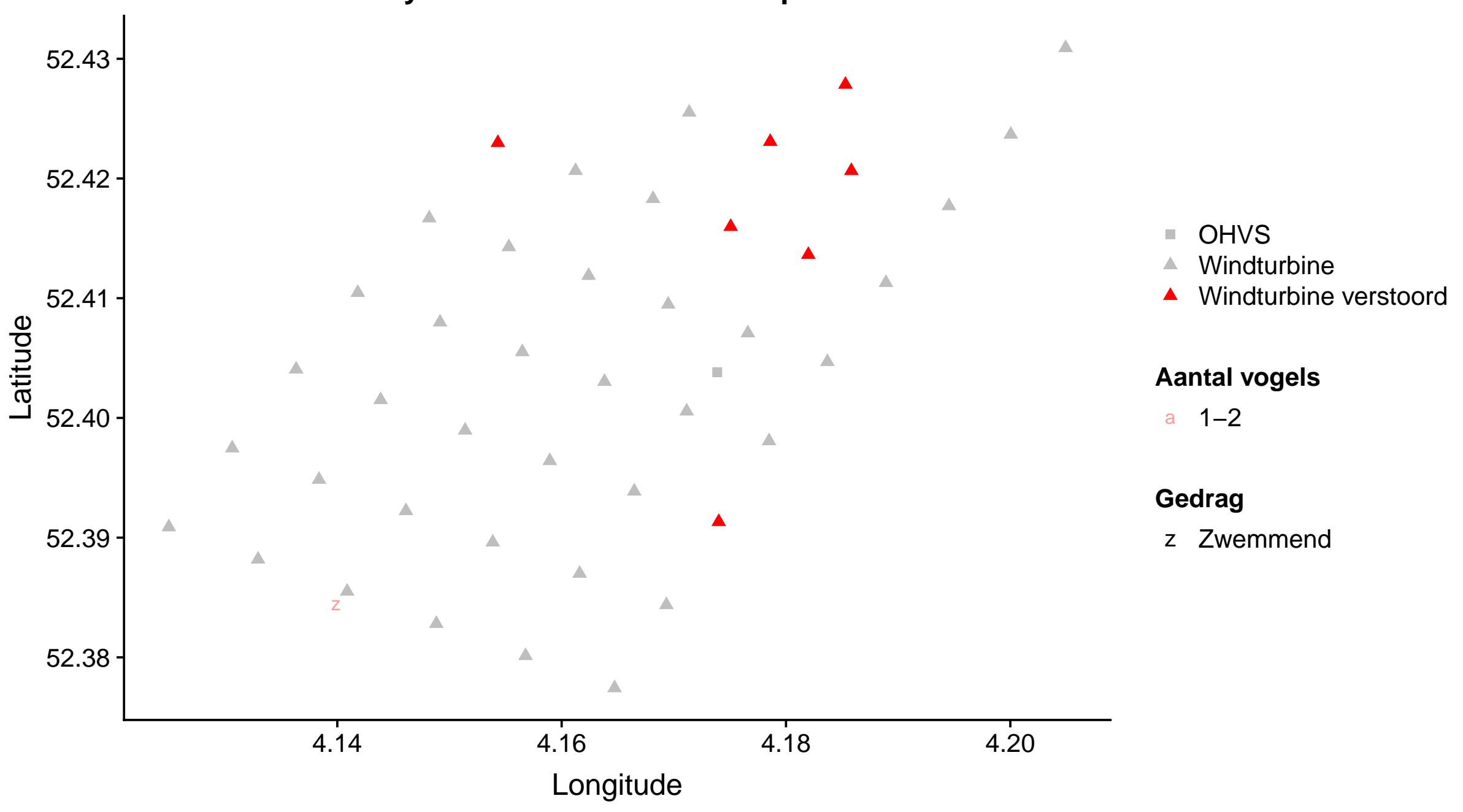


Survey 3: Bruinvis in windmolenpark LUD

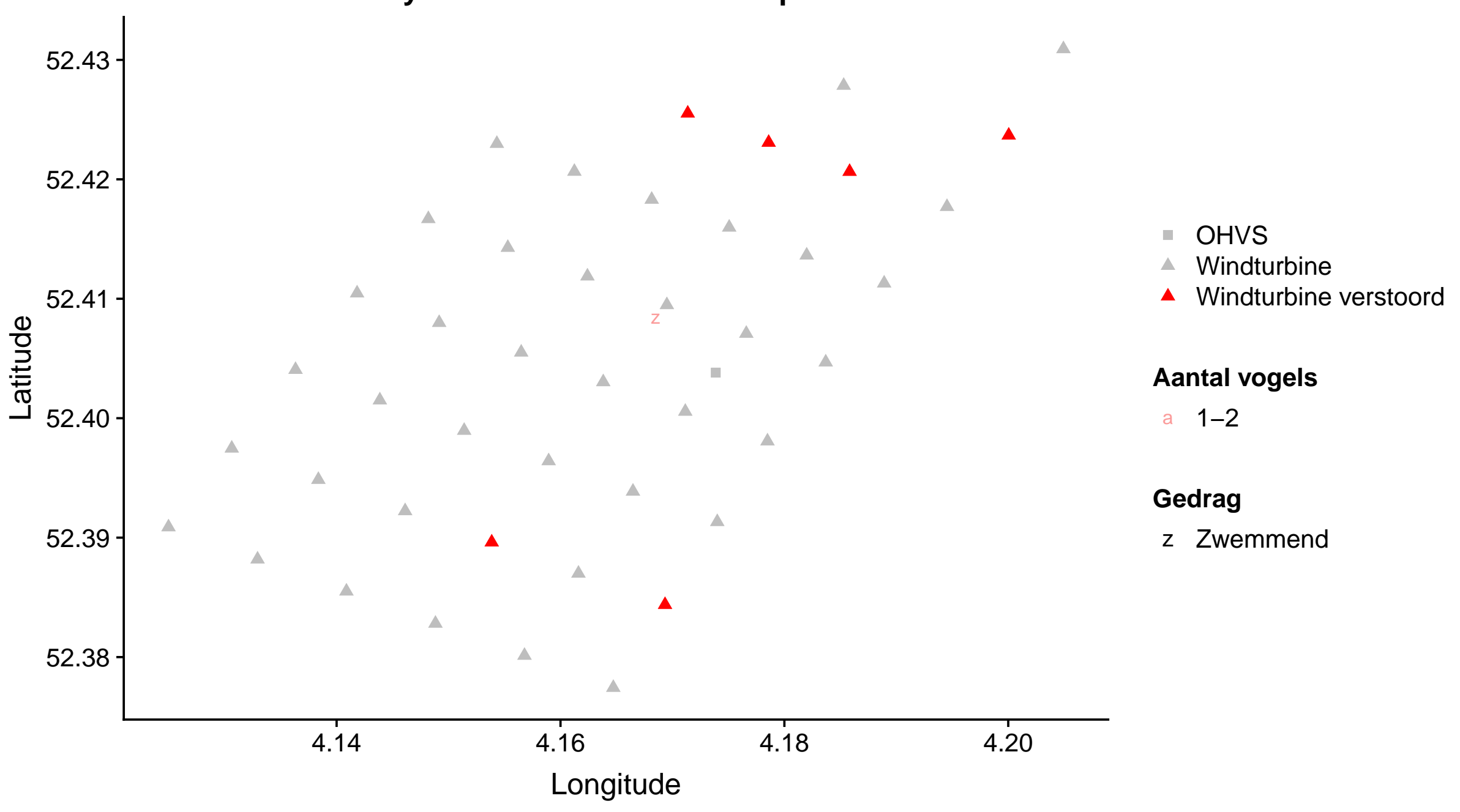


Survey 3: Gewone zeehond in windmolenpark OWEZ

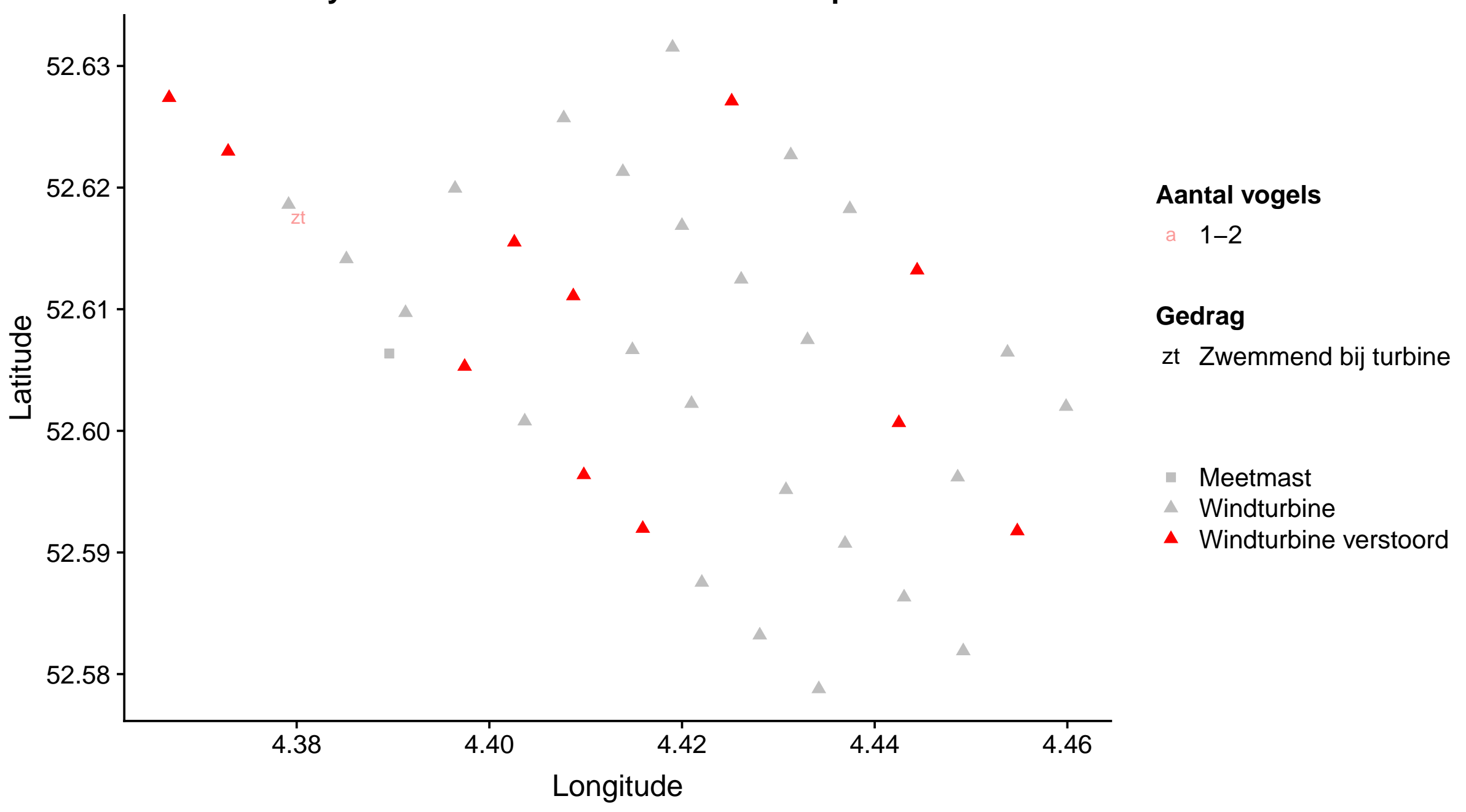


Survey 2: Grijze zeehond in windmolenpark LUD

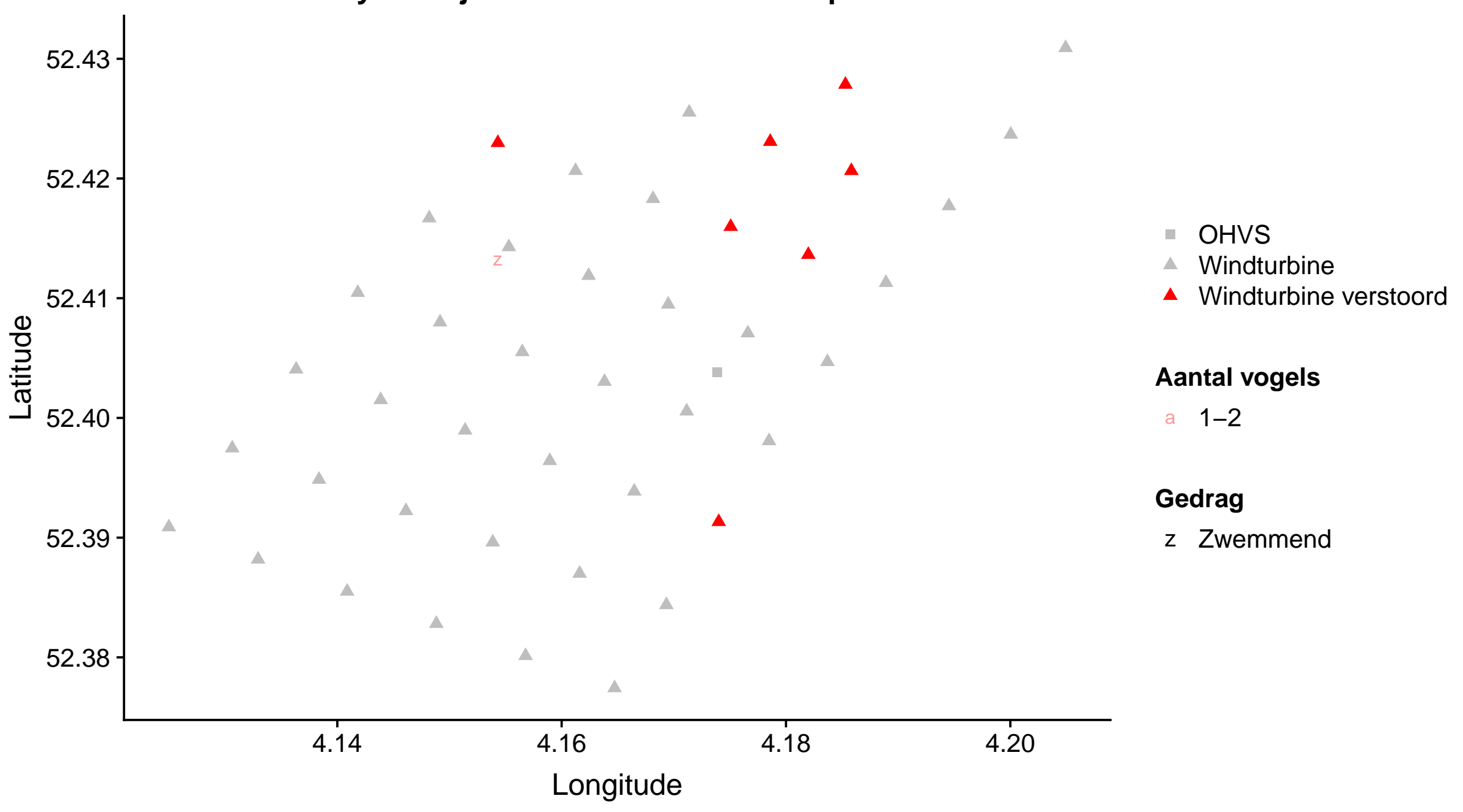


Survey 3: Grijze zeehond in windmolenpark OWEZ

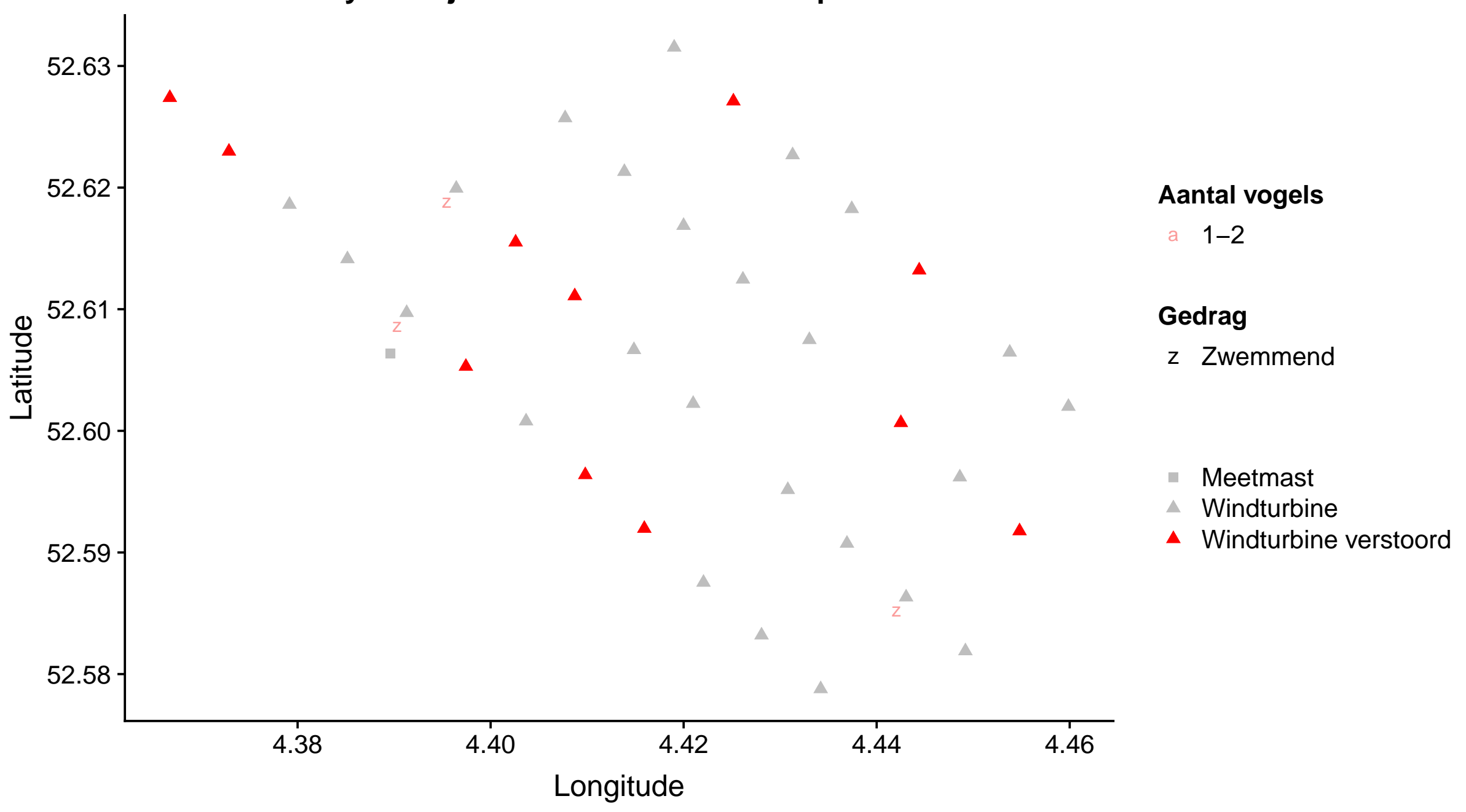


Wageningen Marine Research

T: $+31(0) 317480900$

E: marine-research@wur.nl

www.wur.nl/marine-research

Visitors address

- Ankerpark 27, 1781 AG Den Helder

- Korringaweg 7, 4401 NT Yerseke

- Haringkade 1, 1976 CP IJmuiden
Wageningen Marine Research is the Netherlands research institute established to provide the scientific support that is essential for developing policies and innovation in respect of the marine environment, fishery activities, aquaculture and the maritime sector.

Wageningen University \& Research is specialised in the domain of healthy food and living environment.

\section{The Wageningen Marine Research vision:}

'To explore the potential of marine nature to improve the quality of life.'

\section{The Wageningen Marine Research mission}

- To conduct research with the aim of acquiring knowledge and offering advice on the sustainable management and use of marine and coastal areas.

- Wageningen Marine Research is an independent, leading scientific research institute.

Wageningen Marine Research is part of the international knowledge organisation Wageningen UR (University \& Research centre). Within Wageningen UR, nine specialised research institutes of Stichting Wageningen Research (a Foundation) have joined forces with Wageningen University to help answer the most important questions in the domain of healthy food and living environment. 